Y/SUB/92-28B99923C-Y05, Rev. 1

FINAL

Copy 1

\title{
SOIL MANAGEMENT PLAN FOR THE \\ OAK RIDGE Y-12 NATIONAL SECURITY COMPLEX OAK RIDGE, TENNESSEE
}

Issue Date: March 2005

\author{
Prepared by \\ Science Applications International Corporation \\ 151 Lafayette Drive \\ Oak Ridge, Tennessee 37831 \\ Under Subcontract Number 4300031991
}

for the

Environmental Compliance Department Environment, Safety, and Health Division Y-12 National Security Complex

Oak Ridge, Tennessee 37831

\author{
Managed by \\ BWXT Y-12, L.L.C. \\ for the
}

U. S. Department of Energy

National Nuclear Security Administration

Under Contract No. DE-AC05-00OR22800 


\section{DISCLAIMER}

This report was prepared as an account of work sponsored by an agency of the United States Government. Neither the United States Government nor any agency thereof, nor any of their employees, makes any warranty, express or implied, or assumes any legal liability or responsibility for the accuracy, completeness, or usefulness of any information, apparatus, product, or process disclosed, or represents that its use would not infringe privately owned rights. Reference herein to any specific commercial product, process, or service by trade name, trademark, manufacturer, or otherwise, does not necessarily constitute or imply its endorsement, recommendation, or favoring of the United States Government or any agency thereof. The views and opinions of authors expressed herein do not necessarily state or reflect those of the United States Government or any agency thereof. 


\section{SCIENCE APPLICATIONS INTERNATIONAL CORPORATION}

contributed to the preparation of this document and should not be considered an eligible contractor for its review. 


\title{
SOIL MANAGEMENT PLAN FOR THE OAK RIDGE Y-12 NATIONAL SECURITY COMPLEX OAK RIDGE, TENNESSEE
}

Issue Date: March 2005

\author{
Prepared by \\ Science Applications International Corporation \\ 151 Lafayette Drive \\ Oak Ridge, Tennessee 37831 \\ Under Subcontract Number 4300031991
}

for the

Environmental Compliance Department

Environment, Safety, and Health Division

Y-12 National Security Complex

Oak Ridge, Tennessee 37831

\author{
Managed by \\ BWXT Y-12, L.L.C. \\ for the
}

U. S. Department of Energy

National Nuclear Security Administration

Under Contract No. DE-AC05-00OR22800 



\section{CONTENTS}

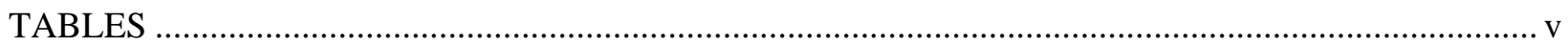

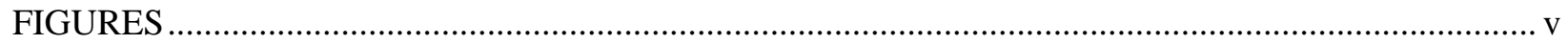

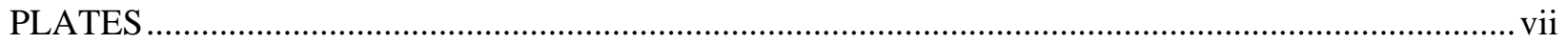

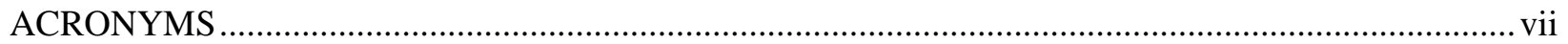

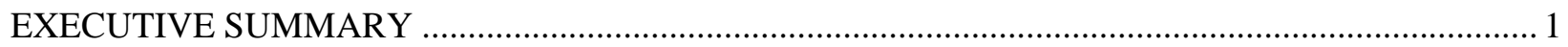

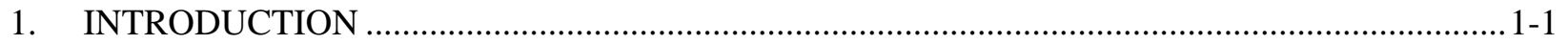

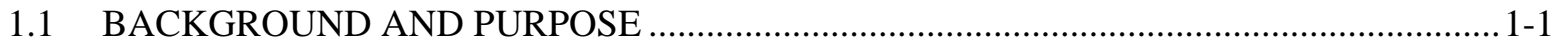

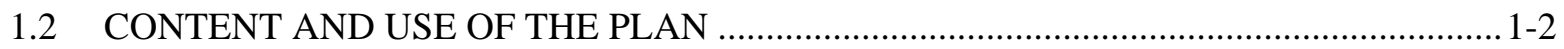

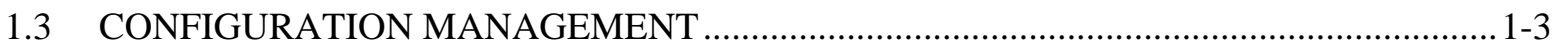

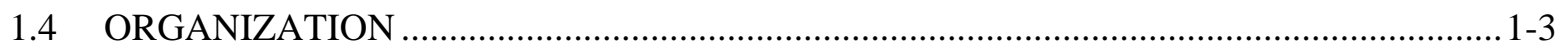

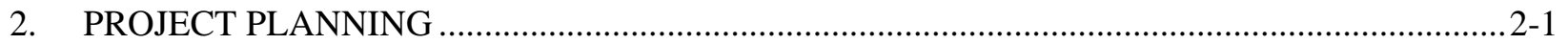

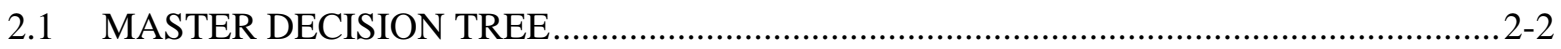

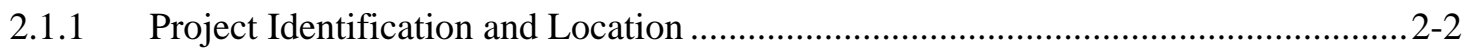

2.1.2 Soil Management in Areas Subject to Regulatory Programs ....................................2-5

2.1.3 Other Program and Regulatory Requirements Impacting Soil Excavation and

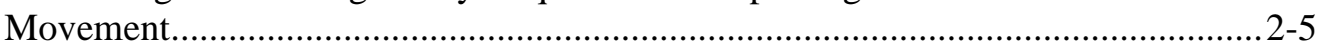

2.2 USING THE COMPREHENSIVE ENVIRONMENTAL RESPONSE, COMPENSATION, AND LIABILITY ACT DECISION TREE ..........................................2-8

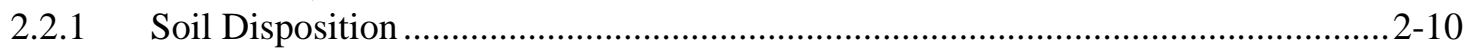

2.2.2 Soil That Cannot be Managed Within the Unit .......................................................2-10

2.3 USING THE RESOURCE CONSERVATION AND RECOVERY ACT DECISION

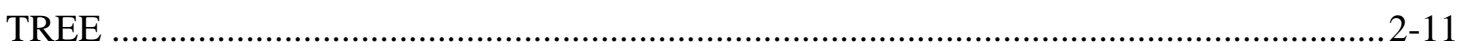

2.3.1 Soil Movement Within a Hazardous Waste Management Unit ................................2-11

2.3.2 Soil Management Within a Solid Waste Management Unit.....................................2-17

2.3.3 Area of Suspected Contamination, Listed Hazardous Waste .................................... 2-18

2.3.4 Area of Suspected Contamination, Characteristic Waste ........................................2-18

2.4 USING THE TOXIC SUBSTANCES CONTROL ACT DECISION TREE........................2-19

2.4.1 Polychlorinated Biphenyl Contamination Due to Unknown Sources .....................2-19

2.4.2 Polychlorinated Biphenyl Contamination Due to Pre-1978 Spills ..........................2-22

2.4.3 Releases of Polychlorinated Biphenyls Due to Post-1978 Spills ...........................2-22

2.5 USING THE ATOMIC ENERGY ACT DECISION TREE .............................................2-22

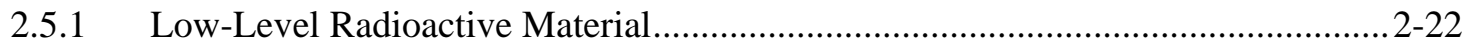

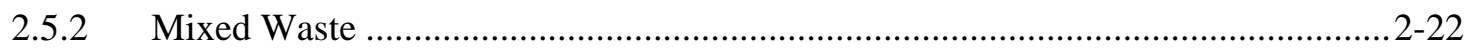

2.6 USING THE CLEAN AREA DECISION TREE ..........................................................2-24

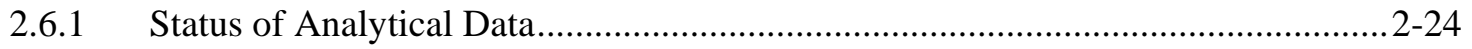

3. LEGACY CONTAMINATION AND ENVIRONMENTAL INFRASTRUCTURE .......................3-1

3.1 HISTORICAL RESPONSE ACTIONS AND COMPREHENSIVE ENVIRONMENTAL RESPONSE, COMPENSATION, AND LIABILITY ACT

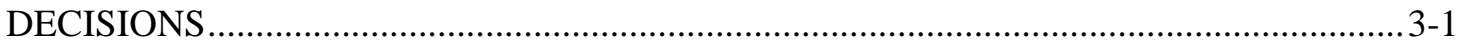

3.1.1 Historical Response Actions ................................................................................ 3-2

3.1.2 Comprehensive Environmental Response, Compensation, and Liability Act

Actions in the Upper East Fork Poplar Creek Watershed (Y-12 National

Security Complex).............................................................................................. 3-2

3.1.3 Comprehensive Environmental Response, Compensation, and Liability Act

Actions in the Bear Creek Watershed.... 
3.1.4 Comprehensive Environmental Response, Compensation, and Liability Act Actions in the Chestnut Ridge Administrative Area ............................................... 3-17

3.2 SOLID WASTE MANAGEMENT UNITS ....................................................................

3.2.1 Upper East Fork Poplar Creek Watershed (the Y-12 National Security

Complex)....

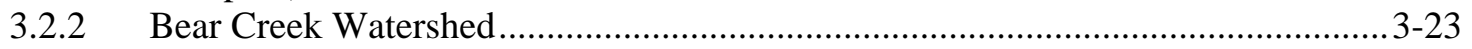

3.2.3 Chestnut Ridge Administrative Area …................................................................. $3-24$

3.3 SUMMARY OF ENVIRONMENTAL CONTAMINATION IN SOIL ..............................3-24

3.3.1 Upper East Fork Poplar Creek Watershed......................................................... 3-24

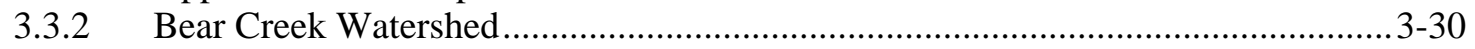

3.3.3 Chestnut Ridge Administrative Area …...............................................................

3.4 CURRENT AND FUTURE ENVIRONMENTAL INFRASTRUCTURE ...........................3-43

3.4.1 Upper East Fork Poplar Creek Watershed (the Y-12 National Security

Complex) ........................................................................................................ 3-43

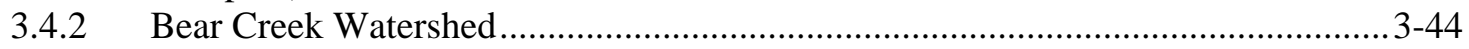

3.4.3 Chestnut Ridge Administrative Area ….................................................................. 3-44

4. WASTE MANAGEMENT PROTOCOLS AND PROCEDURES ….........................................4-1

4.1 OVERVIEW OF THE SOIL DISPOSITION PROCESS......................................................4-1

4.2 ON-SITE MANAGEMENT OF EXCAVATED SOILS: REGULATORY REQUIREMENTS AND BEST MANAGEMENT PRACTICES ….................................... 4-1

4.2.1 Clean Water Act Best Management Practices ...................................................... 4-1

4.2.2 Contaminated Soil Regulatory Requirements and Best Management Practices ....... 4-2

4.3 CHARACTERIZATION OF EXCAVATED SOIL FOR DISPOSITION............................4-3

4.4 ESTABLISHING A WASTE DISPOSITION PATHWAY …..............................................4-4

4.4.1 On-site Disposal Options and Associated Waste Acceptance Criteria.......................4-4

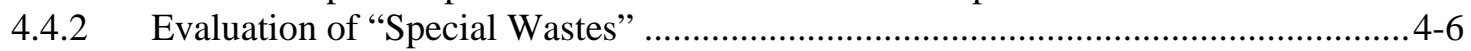

4.4.3 Classified Waste Disposal .................................................................................. 4-7

4.4.4 Class IV Facility Construction/Demolition Waste Disposal ...................................4-7

4.4.5 On-site Construction/Demolition Spoil Areas........................................................ 4-7

4.4.6 Oak Ridge Reservation Environmental Management Waste Management

Facility ......................................................................................... 4

4.4.7 Off-site Disposal Options ........................................................................... 4-8

4.5 TRANSPORTATION REQUIREMENTS .................................................................... $4-8$

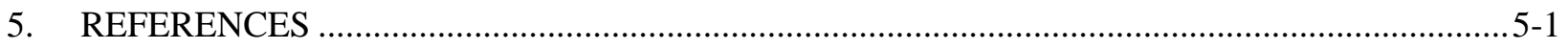

APPENDIX A BWXT Y-12, L.L.C. NATIONAL ENVIRONMENTAL POLICY ACT REVIEW

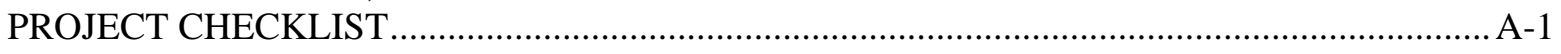

APPENDIX B SOURCE AREA SUMMARY INFORMATION FROM REMEDIAL ACTION INFORMATION MANAGEMENT SYSTEM (RAIMS) ......................................................... B-1

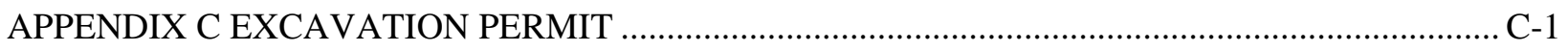

APPENDIX D POTENTIAL SOURCE AREAS FOR RADIOACTIVE SOIL CONTAMINATION ... D-1 


\section{TABLES}

2.1 Y-12 National Security Complex soil disturbance project CERCLA Screening Checklist.............2-7

3.1 RCRA post-closure status for former treatment, storage, and disposal units at Y-12 ...................3-3

3.2 Summary of completed and ongoing CERCLA response actions in the UEFPC Watershed ...........3-6

3.3 Primary actions under a Soil Removal Alternative, UEFPC focused feasibility study .................3-14

3.4 Summary of completed and ongoing CERCLA response actions in the Bear Creek

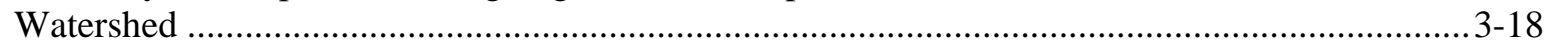

3.5 Summary of completed and ongoing CERCLA response actions in the Chestnut Ridge

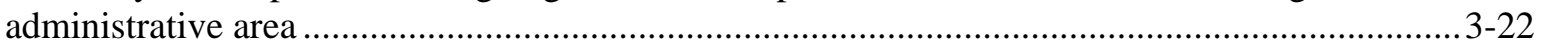

3.6 Legacy waste management units in the Bear Creek Hydrogeologic Regime ...............................3-34

3.7 Legacy and active waste management units in the Chestnut Ridge Hydrogeologic Regime .........3-41

\section{FIGURES}

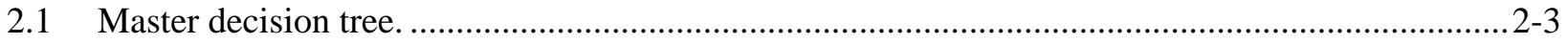

2.2 Y-12 National Security Complex soil disturbance project CERCLA screening process.................2-6

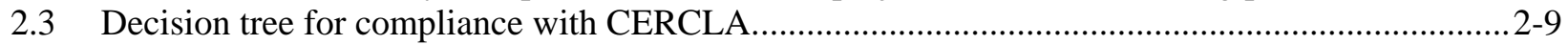

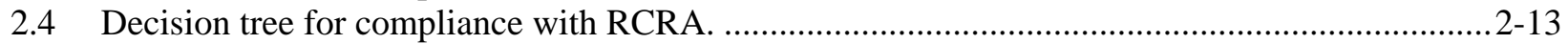

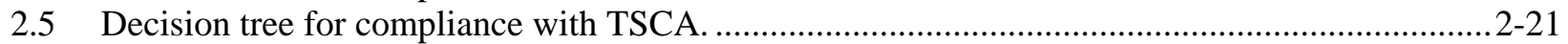

2.6 Decision tree for radiologically contaminated soil. ...................................................................2-23

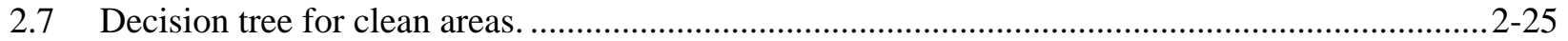

3.1 Locations of RCRA TSD units in post-closure status at Y-12 and waste management units in the Chestnut Ridge administrative area. .................................................................................. 3-5

3.2 Locations of former RMPE actions and completed and ongoing CERCLA response actions in the UEFPC Watershed and Chestnut Ridge administrative area. ............................................ 3-11

3.3 Estimated areas of soil excavation in the western Y-12 area under a soil removal alternative, UEFPC Focused Feasibility Study...................................................................... 3-15

3.4 Estimated areas of soil excavation in the eastern Y-12 area under a soil removal alternative,

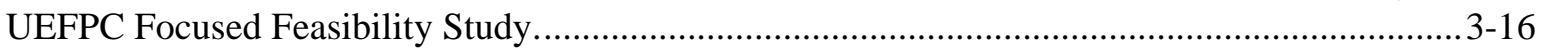

3.5 Locations of completed and ongoing CERCLA response actions in the Bear Creek

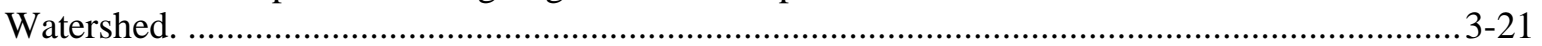

3.6 Historical mercury use and soil investigation areas at Y-12 ...................................................2-25

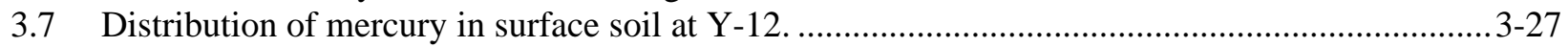

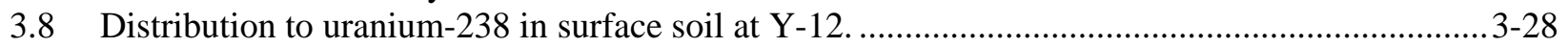

3.9 Distribution of total PCBs in surface soil at Y-12. ............................................................... $3-29$

3.10 Summary of surface soil risks for the unprotected industrial worker and site-specific soils data locations for the UEFPC Watershed................................................................................ 3-31

3.11 Y-12 radiological characterization summary - UEFPC Watershed and Chestnut Ridge

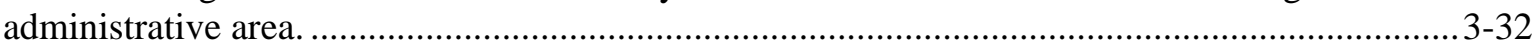

3.12 Distribution of risks to hypothetical industrial workers and unprotected maintenance workers in Bear Creek Valley.................................................................................................. 3-35

3.13 Distribution of cadmium in Bear Creek floodplain soils and sediments....................................3-37

3.14 Distribution of uranium-238 in Bear Creek floodplain soils and sediments...............................3-38

3.15 Distribution of total PCBs in Bear Creek floodplain soils and sediments. ..................................3-39

3.16 Y-12 radiological characterization summary - Bear Creek Watershed........................................3-41 
3.17 Source areas, environmental infrastructure, and radiological contamination areas in the Bear Creek Watershed.

3-18 Source areas, environmental infrastructure, and radiological contamination areas in the Chestnut Ridge administrative area. 
Y/SUB/92-28B99923C-Y05, Rev. 1

FINAL

Copy 1

\title{
SOIL MANAGEMENT PLAN FOR THE \\ OAK RIDGE Y-12 NATIONAL SECURITY COMPLEX OAK RIDGE, TENNESSEE
}

Issue Date: March 2005

Prepared by

Science Applications International Corporation 151 Lafayette Drive Oak Ridge, Tennessee 37831 Under Subcontract Number 4300031991

for the

Environmental Compliance Department Environment, Safety, and Health Division Y-12 National Security Complex

Oak Ridge, Tennessee 37831

\author{
Managed by \\ BWXT Y-12, L.L.C. \\ for the
}

U. S. Department of Energy

National Nuclear Security Administration

Under Contract No. DE-AC05-00OR22800 


\section{DISCLAIMER}

This report was prepared as an account of work sponsored by an agency of the United States Government. Neither the United States Government nor any agency thereof, nor any of their employees, makes any warranty, express or implied, or assumes any legal liability or responsibility for the accuracy, completeness, or usefulness of any information, apparatus, product, or process disclosed, or represents that its use would not infringe privately owned rights. Reference herein to any specific commercial product, process, or service by trade name, trademark, manufacturer, or otherwise, does not necessarily constitute or imply its endorsement, recommendation, or favoring of the United States Government or any agency thereof. The views and opinions of authors expressed herein do not necessarily state or reflect those of the United States Government or any agency thereof. 


\section{SCIENCE APPLICATIONS INTERNATIONAL CORPORATION}

contributed to the preparation of this document and should not be considered an eligible contractor for its review. 


\title{
SOIL MANAGEMENT PLAN FOR THE OAK RIDGE Y-12 NATIONAL SECURITY COMPLEX OAK RIDGE, TENNESSEE
}

\author{
Issue Date: March 2005
}

Prepared by

Science Applications International Corporation

151 Lafayette Drive

Oak Ridge, Tennessee 37831

Under Subcontract Number 4300031991

for the

Environmental Compliance Department Environment, Safety, and Health Division Y-12 National Security Complex

Oak Ridge, Tennessee 37831

\author{
Managed by \\ BWXT Y-12, L.L.C. \\ for the
}

U. S. Department of Energy

National Nuclear Security Administration

Under Contract No. DE-AC05-00OR22800 



\section{CONTENTS}

TABLES

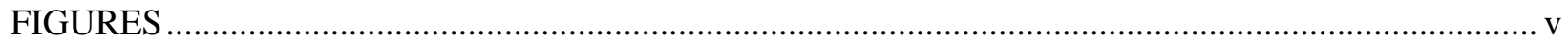

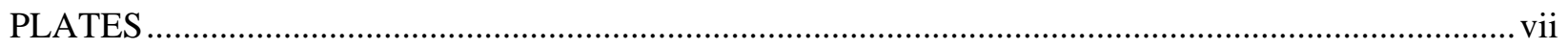

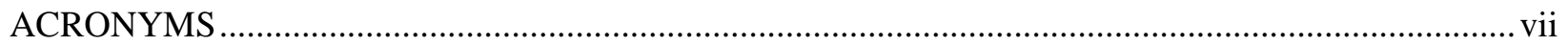

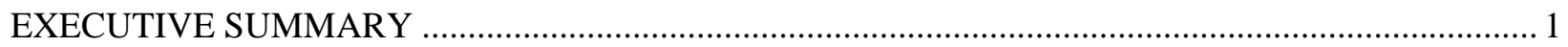

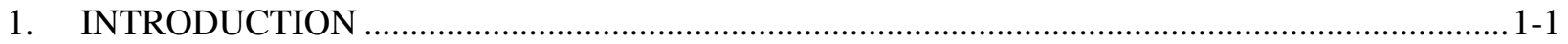

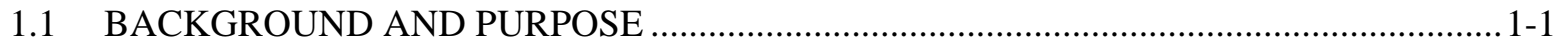

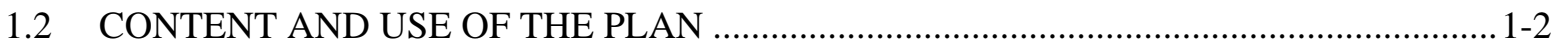

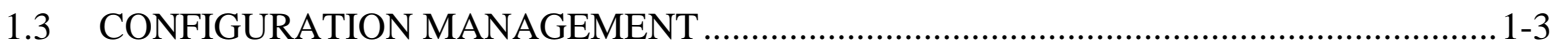

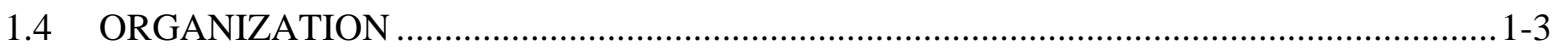

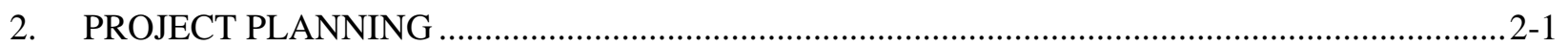

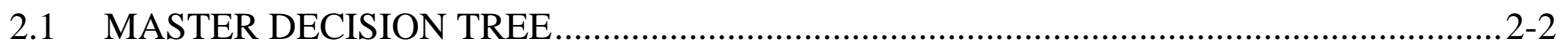

2.1.1 Project Identification and Location ...................................................................... 2-2

2.1.2 Soil Management in Areas Subject to Regulatory Programs ...................................2-5

2.1.3 Other Program and Regulatory Requirements Impacting Soil Excavation and

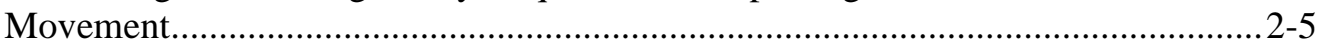

2.2 USING THE COMPREHENSIVE ENVIRONMENTAL RESPONSE, COMPENSATION, AND LIABILITY ACT DECISION TREE ....................................... $2-8$

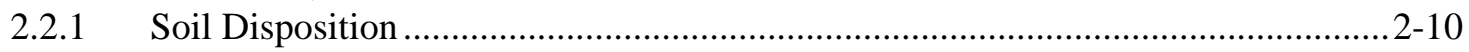

2.2.2 Soil That Cannot be Managed Within the Unit ....................................................2-10

2.3 USING THE RESOURCE CONSERVATION AND RECOVERY ACT DECISION

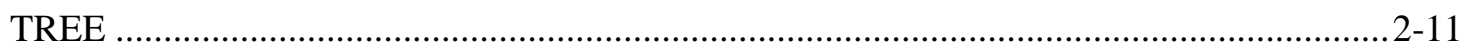

2.3.1 Soil Movement Within a Hazardous Waste Management Unit ...............................2-11

2.3.2 Soil Management Within a Solid Waste Management Unit....................................2-17

2.3.3 Area of Suspected Contamination, Listed Hazardous Waste ................................... 2-18

2.3.4 Area of Suspected Contamination, Characteristic Waste .......................................2-18

2.4 USING THE TOXIC SUBSTANCES CONTROL ACT DECISION TREE.......................2-19

2.4.1 Polychlorinated Biphenyl Contamination Due to Unknown Sources .....................2-19

2.4.2 Polychlorinated Biphenyl Contamination Due to Pre-1978 Spills .........................2-22

2.4.3 Releases of Polychlorinated Biphenyls Due to Post-1978 Spills ...........................2-22

2.5 USING THE ATOMIC ENERGY ACT DECISION TREE ..........................................2-22

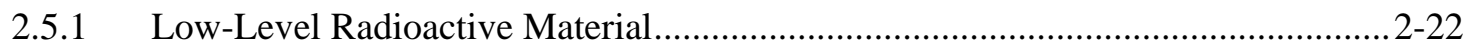

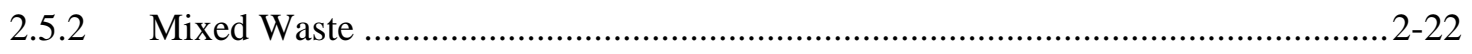

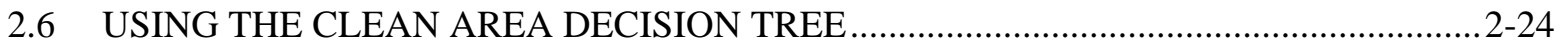

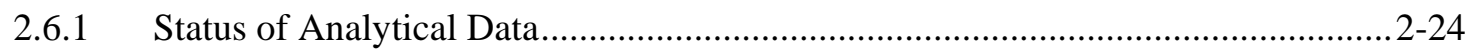

3. LEGACY CONTAMINATION AND ENVIRONMENTAL INFRASTRUCTURE .......................3-1

3.1 HISTORICAL RESPONSE ACTIONS AND COMPREHENSIVE ENVIRONMENTAL RESPONSE, COMPENSATION, AND LIABILITY ACT

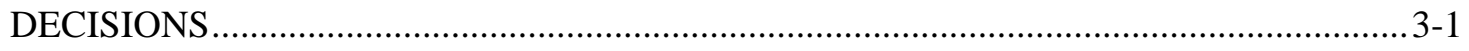

3.1.1 Historical Response Actions .......................................................................... 3-2

3.1.2 Comprehensive Environmental Response, Compensation, and Liability Act

Actions in the Upper East Fork Poplar Creek Watershed (Y-12 National

Security Complex)..............................................................................................

3.1.3 Comprehensive Environmental Response, Compensation, and Liability Act Actions in the Bear Creek Watershed.... 
3.1.4 Comprehensive Environmental Response, Compensation, and Liability Act Actions in the Chestnut Ridge Administrative Area ............................................ 3-17

3.2 SOLID WASTE MANAGEMENT UNITS ............................................................... 3-23

3.2.1 Upper East Fork Poplar Creek Watershed (the Y-12 National Security

Complex).....

3.2.2 Bear Creek Watershed ................................................................................ 3-23

3.2.3 Chestnut Ridge Administrative Area ….............................................................. 3-24

3.3 SUMMARY OF ENVIRONMENTAL CONTAMINATION IN SOIL ............................ 3-24

3.3.1 Upper East Fork Poplar Creek Watershed....................................................... 3-24

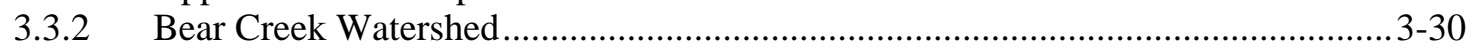

3.3.3 Chestnut Ridge Administrative Area ...................................................................

3.4 CURRENT AND FUTURE ENVIRONMENTAL INFRASTRUCTURE ..........................3-43

3.4.1 Upper East Fork Poplar Creek Watershed (the Y-12 National Security

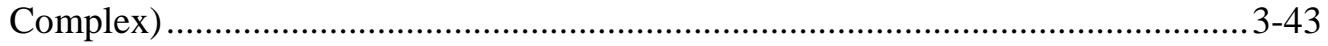

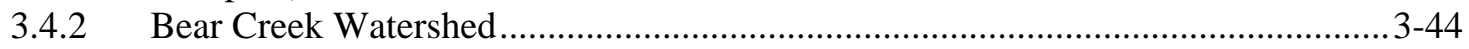

3.4.3 Chestnut Ridge Administrative Area ................................................................... $4-44$

4. WASTE MANAGEMENT PROTOCOLS AND PROCEDURES ….......................................

4.1 OVERVIEW OF THE SOIL DISPOSITION PROCESS .....................................................4-1

4.2 ON-SITE MANAGEMENT OF EXCAVATED SOILS: REGULATORY REQUIREMENTS AND BEST MANAGEMENT PRACTICES ........................................4-1

4.2.1 Clean Water Act Best Management Practices ...................................................... 4-1

4.2.2 Contaminated Soil Regulatory Requirements and Best Management Practices ....... 4-2

4.3 CHARACTERIZATION OF EXCAVATED SOIL FOR DISPOSITION ...........................4-3

4.4 ESTABLISHING A WASTE DISPOSITION PATHWAY ….............................................4-4

4.4.1 On-site Disposal Options and Associated Waste Acceptance Criteria......................4-4

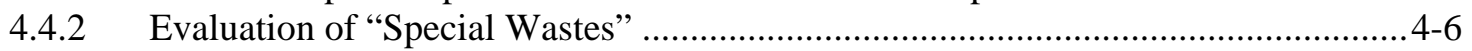

4.4.3 Classified Waste Disposal .................................................................................. 4-7

4.4.4 Class IV Facility Construction/Demolition Waste Disposal ................................... 4-7

4.4.5 On-site Construction/Demolition Spoil Areas........................................................4-7

4.4.6 Oak Ridge Reservation Environmental Management Waste Management

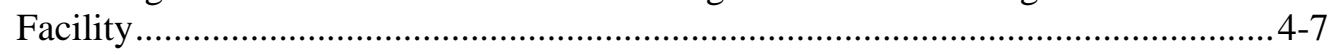

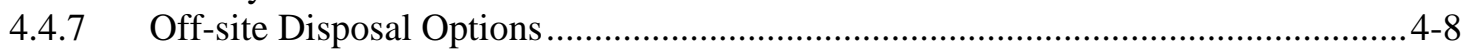

4.5 TRANSPORTATION REQUIREMENTS ................................................................. $4-8$

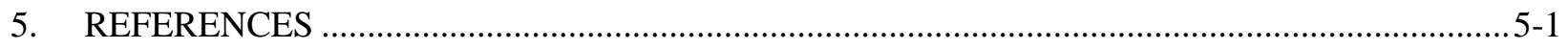

APPENDIX A BWXT Y-12, L.L.C. NATIONAL ENVIRONMENTAL POLICY ACT REVIEW

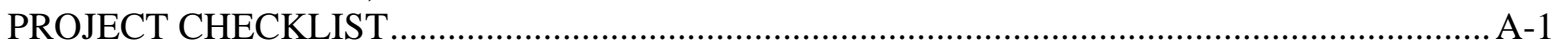

APPENDIX B SOURCE AREA SUMMARY INFORMATION FROM REMEDIAL ACTION INFORMATION MANAGEMENT SYSTEM (RAIMS) ........................................................ B-1

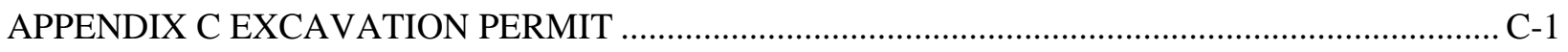

APPENDIX D POTENTIAL SOURCE AREAS FOR RADIOACTIVE SOIL CONTAMINATION ... D-1 


\section{TABLES}

2.1 Y-12 National Security Complex soil disturbance project CERCLA Screening Checklist.............2-7

3.1 RCRA post-closure status for former treatment, storage, and disposal units at Y-12 ..................3-3

3.2 Summary of completed and ongoing CERCLA response actions in the UEFPC Watershed ..........3-6

3.3 Primary actions under a Soil Removal Alternative, UEFPC focused feasibility study .................3-14

3.4 Summary of completed and ongoing CERCLA response actions in the Bear Creek

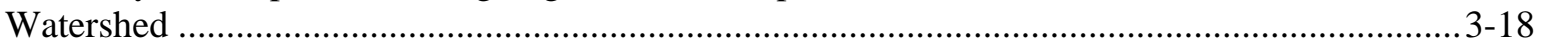

3.5 Summary of completed and ongoing CERCLA response actions in the Chestnut Ridge

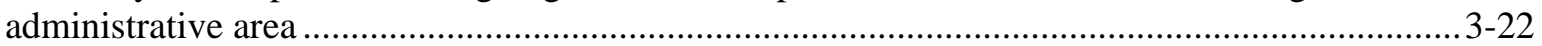

3.6 Legacy waste management units in the Bear Creek Hydrogeologic Regime ..............................3-34

3.7 Legacy and active waste management units in the Chestnut Ridge Hydrogeologic Regime .........3-41

\section{FIGURES}

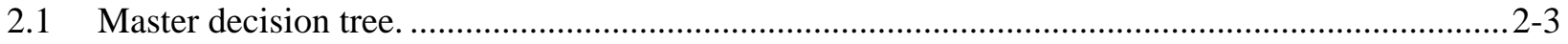

2.2 Y-12 National Security Complex soil disturbance project CERCLA screening process.................2-6

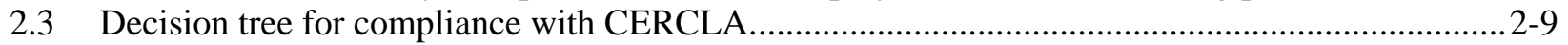

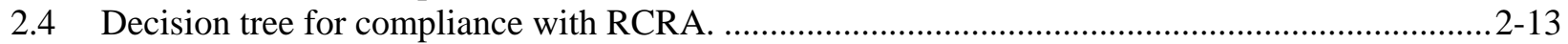

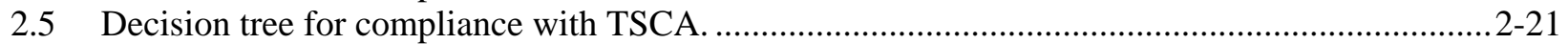

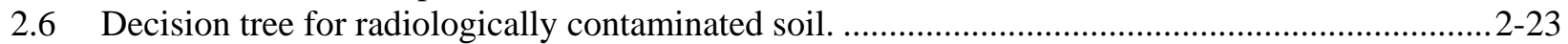

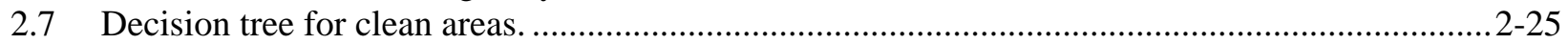

3.1 Locations of RCRA TSD units in post-closure status at Y-12 and waste management units in the Chestnut Ridge administrative area. ..............................................................................

3.2 Locations of former RMPE actions and completed and ongoing CERCLA response actions in the UEFPC Watershed and Chestnut Ridge administrative area. ........................................... 3-11

3.3 Estimated areas of soil excavation in the western Y-12 area under a soil removal alternative, UEFPC Focused Feasibility Study.

3.4 Estimated areas of soil excavation in the eastern Y-12 area under a soil removal alternative, UEFPC Focused Feasibility Study.....

3.5 Locations of completed and ongoing CERCLA response actions in the Bear Creek

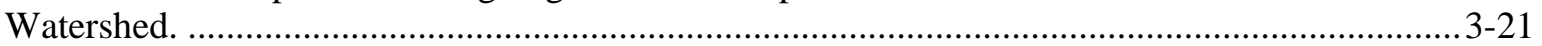

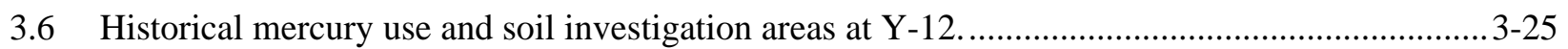

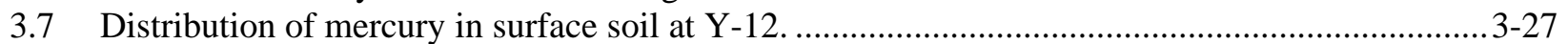

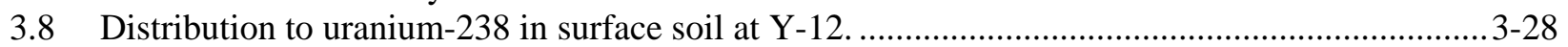

3.9 Distribution of total PCBs in surface soil at Y-12.................................................................. 3-29

3.10 Summary of surface soil risks for the unprotected industrial worker and site-specific soils data locations for the UEFPC Watershed............................................................................. 3-31

3.11 Y-12 radiological characterization summary - UEFPC Watershed and Chestnut Ridge

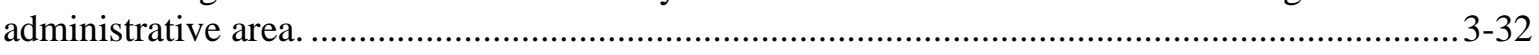

3.12 Distribution of risks to hypothetical industrial workers and unprotected maintenance workers in Bear Creek Valley................................................................................................. 3-35

3.13 Distribution of cadmium in Bear Creek floodplain soils and sediments.....................................3-37

3.14 Distribution of uranium-238 in Bear Creek floodplain soils and sediments...............................3-38

3.15 Distribution of total PCBs in Bear Creek floodplain soils and sediments. ..................................3-39

3.16 Y-12 radiological characterization summary - Bear Creek Watershed...................................... 3-41 
3.17 Source areas, environmental infrastructure, and radiological contamination areas in the Bear Creek Watershed.

3-18 Source areas, environmental infrastructure, and radiological contamination areas in the Chestnut Ridge administrative area. 


\section{PLATES}

1 Waste management units and source area locations in the Bear Creek, Upper East Fork

Poplar Creek, and Chestnut Ridge areas. .

1A Waste management units and source area locations in the Upper East Fork Poplar Creek

Watershed. 3

1B Waste management units and source area locations in the Upper East Fork Poplar Creek

Watershed.

1C Waste management units and source area locations in the Upper East Fork Poplar Creek

Watershed.

2 Source areas, environmental infrastructure, and radiological contamination areas in the Upper East Fork Poplar Creek Watershed.

\section{ACRONYMS}

$\begin{array}{ll}\text { AEA } & \text { Atomic Energy Act } \\ \text { AHA } & \text { activity hazard analysis } \\ \text { AOC } & \text { area of contamination } \\ \text { BCBG } & \text { Bear Creek Burial Grounds } \\ \text { BCV } & \text { Bear Creek Valley } \\ \text { BMP } & \text { best management practice } \\ \text { BY/BY } & \text { Boneyard/Burnyard } \\ \text { C/D } & \text { construction/demolition } \\ \text { CAMU } & \text { Corrective Action Management Unit } \\ \text { CERCLA } & \text { Comprehensive Environmental Response, Compensation, and Liability Act } \\ \text { CFR } & \text { Code of Federal Regulations } \\ \text { CMTS } & \text { Central Mercury Treatment System } \\ \text { COC } & \text { constituent of concern } \\ \text { CWA } & \text { Clean Water Act } \\ \text { CX } & \text { Categorical Exclusion } \\ \text { DARA } & \text { Disposal Area Remedial Action } \\ \text { DOE } & \text { U. S. Department of Energy } \\ \text { EEVOC } & \text { East End Volatile Organic Compound } \\ \text { EM } & \text { Environmental Management } \\ \text { EMWMF } & \text { Environmental Management Waste Management Facility } \\ \text { EPA } & \text { U. S. Environmental Protection Agency } \\ \text { ES\&H } & \text { Environment, Safety, and Health (Division) } \\ \text { FCAP } & \text { Filled Coal Ash Pond } \\ \text { FFA } & \text { Federal Facilities Agreement } \\ \text { FFS } & \text { focused feasibility study } \\ \text { FR } & \text { Federal Register } \\ \text { FY } & \text { fiscal year } \\ \text { HSWA } & \text { RCRA Hazardous and Solid Waste Amendments of 1984 } \\ \text { IDW } & \text { investigation-derived waste } \\ \text { IH } & \text { industrial hygiene } \\ \text { KHQ } & \text { Kerr Hollow Quarry } \\ \text { LDR } & \text { land disposal restriction } \\ & \end{array}$




\section{PLATES}

1 Waste management units and source area locations in the Bear Creek, Upper East Fork Poplar Creek, and Chestnut Ridge areas. .

1A Waste management units and source area locations in the Upper East Fork Poplar Creek

Watershed.

1B Waste management units and source area locations in the Upper East Fork Poplar Creek

Watershed.

1C Waste management units and source area locations in the Upper East Fork Poplar Creek

Watershed.

2 Source areas, environmental infrastructure, and radiological contamination areas in the Upper East Fork Poplar Creek Watershed.

\section{ACRONYMS}

$\begin{array}{ll}\text { AEA } & \text { Atomic Energy Act } \\ \text { AHA } & \text { activity hazard analysis } \\ \text { AOC } & \text { area of contamination } \\ \text { BCBG } & \text { Bear Creek Burial Grounds } \\ \text { BCV } & \text { Bear Creek Valley } \\ \text { BMP } & \text { best management practice } \\ \text { BY/BY } & \text { Boneyard/Burnyard } \\ \text { C/D } & \text { construction/demolition } \\ \text { CAMU } & \text { Corrective Action Management Unit } \\ \text { CERCLA } & \text { Comprehensive Environmental Response, Compensation, and Liability Act } \\ \text { CFR } & \text { Code of Federal Regulations } \\ \text { CMTS } & \text { Central Mercury Treatment System } \\ \text { COC } & \text { constituent of concern } \\ \text { CWA } & \text { Clean Water Act } \\ \text { CX } & \text { Categorical Exclusion } \\ \text { DARA } & \text { Disposal Area Remedial Action } \\ \text { DOE } & \text { U. S. Department of Energy } \\ \text { EEVOC } & \text { East End Volatile Organic Compound } \\ \text { EM } & \text { Environmental Management } \\ \text { EMWMF } & \text { Environmental Management Waste Management Facility } \\ \text { EPA } & \text { U. S. Environmental Protection Agency } \\ \text { ES\&H } & \text { Environment, Safety, and Health (Division) } \\ \text { FCAP } & \text { Filled Coal Ash Pond } \\ \text { FFA } & \text { Federal Facilities Agreement } \\ \text { FFS } & \text { focused feasibility study } \\ \text { FR } & \text { Federal Register } \\ \text { FY } & \text { fiscal year } \\ \text { HSWA } & \text { RCRA Hazardous and Solid Waste Amendments of 1984 } \\ \text { IDW } & \text { investigation-derived waste } \\ \text { IH } & \text { industrial hygiene } \\ \text { KHQ } & \text { Kerr Hollow Quarry } \\ \text { LDR } & \text { land disposal restriction } \\ & \end{array}$




$\begin{array}{ll}\text { LEFPC } & \text { Lower East Fork Poplar Creek } \\ \text { LUCIP } & \text { Land Use Control Implementation Plan } \\ \text { NCP } & \text { National Contingency Plan } \\ \text { NEPA } & \text { National Environmental Policy Act of 1969 } \\ \text { NFA } & \text { no further action } \\ \text { NFI } & \text { no further investigation } \\ \text { NNSA } & \text { National Nuclear Security Administration } \\ \text { NPDES } & \text { National Pollutant Discharge Elimination System } \\ \text { ORR } & \text { Oak Ridge Reservation } \\ \text { OSHA } & \text { Occupational Safety and Health Administration } \\ \text { PCB } & \text { polychlorinated biphenyl } \\ \text { PK } & \text { process knowledge } \\ \text { PPE } & \text { personal protection equipment } \\ \text { pPm } & \text { part per million } \\ \text { PPt } & \text { part per trillion } \\ \text { RA } & \text { remedial action } \\ \text { RADCON } & \text { radiological control } \\ \text { RAIMS } & \text { Remedial Action Information Management System } \\ \text { RCRA } & \text { Resource Conservation and Recovery Act } \\ \text { RER } & \text { Remediation Effectiveness Report } \\ \text { RI } & \text { remedial investigation } \\ \text { RMPE } & \text { Reduction of Mercury in Plant Effluent } \\ \text { ROD } & \text { record of decision } \\ \text { SVOC } & \text { semivolatile organic compound } \\ \text { SWDF } & \text { solid waste disposal facility } \\ \text { SWMU } & \text { solid waste management unit } \\ \text { TCLP } & \text { toxicity characteristic leaching procedure } \\ \text { TDEC } & \text { Tennessee Department of Environment and Conservation } \\ \text { TDRH } & \text { Tennessee Division of Radiological Health } \\ \text { TSCA } & \text { Toxic Substances Control Act } \\ \text { TSD } & \text { treatment, storage, and disposal } \\ \text { UEFPC } & \text { Upper East Fork Poplar Creek } \\ \text { UNC } & \text { United Nuclear Corporation } \\ \text { UST } & \text { underground storage tank } \\ \text { UTS } & \text { Universal Treatment Standard } \\ \text { VOC } & \text { volatile organic compound } \\ \text { WAC } & \text { waste acceptance criteria } \\ \text { WCPF } & \text { Waste Coolant Processing Facility } \\ \text { WEMA } & \text { West End Mercury Area } \\ \text { WRRP } & \text { Water Resources Restoration Program } \\ \text { Y-12 } & \text { Y-12 National Security Complex } \\ & \end{array}$




\section{EXECUTIVE SUMMARY}

This Soil Management Plan applies to all activities conducted under the auspices of the National Nuclear Security Administration (NNSA) Oak Ridge Y-12 National Security Complex (Y-12) that involve soil disturbance and potential management of waste soil. The plan was prepared under the direction of the Y-12 Environmental Compliance Department of the Environment, Safety, and Health Division. Soil disturbances related to maintenance activities, utility and building construction projects, or demolition projects fall within the purview of the plan. This Soil Management Plan represents an integrated, visually oriented, planning and information resource tool for decision making involving excavation or disturbance of soil at Y-12.

This Soil Management Plan addresses three primary elements.

1. Regulatory and programmatic requirements for management of soil based on the location of a soil disturbance project and/or the regulatory classification of any contaminants that may be present (Chap. 2). Five general regulatory or programmatic classifications of soil are recognized to be potentially present at Y-12; soil may fall under one or more these classifications:

- Comprehensive Environmental Response, Compensation, and Liability Act (CERCLA) pursuant to the Oak Ridge Reservation (ORR) Federal Facilities Agreement;

- $\quad$ Resource Conservation and Recovery Act (RCRA);

- RCRA 3004(u) solid waste managements units pursuant to the RCRA Hazardous and Solid Waste Amendments Act of 1984 permit for the ORR;

- Toxic Substances and Control Act-regulated soil containing polychlorinated biphenyls; and

- Radiologically contaminated soil regulated under the Atomic Energy Act review process.

2. Information for project planners on current and future planned remedial actions (RAs), as prescribed by CERCLA decision documents (including the scope of the actions and remedial goals), land use controls implemented to support or maintain RAs, RCRA post-closure regulatory requirements for former waste management units, legacy contamination source areas and distribution of contamination in soils, and environmental infrastructure (e.g., caps, monitoring systems, etc.) that is in place or planned in association with RAs.

3. Regulatory considerations and processes for management and disposition of waste soil upon generation, including regulatory drivers, best management practices (BMPs), waste determination protocols, waste acceptance criteria, and existing waste management procedures and BMPs for Y-12.

This Soil Management Plan provides information to project planners to better coordinate their activities with other organizations and programs with a vested interest in soil disturbance activities at Y-12. The information allows project managers and maintenance personnel to evaluate and anticipate potential contaminant levels that may be present at a proposed soil disturbance site prior to commencement of activities and allows a more accurate assessment of potential waste management requirements. 
04-120(E)/030205 


\section{INTRODUCTION}

This Soil Management Plan applies to all activities conducted under the auspices of the National Nuclear Security Administration (NNSA) Oak Ridge Y-12 National Security Complex (Y-12) that involve soil disturbance and potential management of waste soil. This plan was prepared under the direction of the Y-12 Environmental Compliance Department of the Environment, Safety, and Health (ES\&H) Division. Planned soil disturbances related to maintenance activities, utility and building construction projects, or demolition projects fall within the purview of the plan. The plan may also serve as a useful reference for environmental projects conducted under the Comprehensive Environmental Response, Compensation, and Liability Act (CERCLA); however, such projects typically develop their own waste management specifications, including any special provisions for management of wastes within CERCLA areas of contamination (AOCs). This Soil Management Plan represents an integrated planning tool and information resource that encompasses land use controls; various potential regulatory controls; legacy contaminants and related remedial actions (RAs); environmental infrastructure; and waste soil management, characterization, and disposition.

\subsection{BACKGROUND AND PURPOSE}

Soil disturbance and excavation within Y-12 is frequently required as part of numerous activities, including routine maintenance projects and new utility or building construction. The need for a soil management plan has long been recognized and an initial version of a soil management plan was prepared in 1993 that focused almost exclusively on regulatory processes for management of excavated soils as wastes (Radian 1993). With maturation of the Oak Ridge Reservation (ORR) Environmental Management (EM) Program, along with Y-12 modernization plans and footprint reduction activities, the need for a more comprehensive plan is evident. A large collection of data has been compiled from historical and CERCLA characterization projects that is now available for use during planning for soil excavations. Additionally, numerous environmental response actions have been completed and future actions planned, which must be considered when planning for soil disturbance activities.

In consideration of the evolving complexity of programmatic interactions and regulatory requirements noted above, the objective of this revised Soil Management Plan is to serve as an information resource and decision-making tool for Y-12 project managers that achieves three objectives:

1. Provides regulatory and programmatic requirements for management of soil based on the location of a soil disturbance project and/or the regulatory classification of any contaminants that may be present (Chap. 2). Five general regulatory or programmatic classifications of soil are recognized to be potentially present at Y-12; soil may fall under one or more these classifications:

- CERCLA pursuant to the ORR Federal Facilities Agreement (FFA);

- $\quad$ Resource Conservation and Recovery Act (RCRA);

- $\quad$ RCRA 3004(u) solid waste managements units (SWMUs) pursuant to the RCRA Hazardous and Solid Waste Amendments Act of 1984 (HSWA) permit for ORR;

- Toxic Substances and Control Act (TSCA)-regulated soil containing polychlorinated biphenyls (PCBs); and

- Radiologically contaminated soil regulated under the Atomic Energy Act (AEA) review process. 
2. Presents information for project planners on current and future planned RAs, as prescribed by CERCLA decision documents (including the scope of the actions and remedial goals), land use controls implemented to support or maintain RAs, RCRA post-closure regulatory requirements for former waste management units, legacy contamination source areas and distribution of contamination in soils, and environmental infrastructure (e.g., caps, monitoring systems, etc.) that is in place or planned in association with RAs.

3. Presents regulatory considerations and processes for management and disposition of waste soil upon generation, including regulatory drivers, best management practices (BMPs), waste determination protocols, waste acceptance criteria (WAC), and existing waste management procedures and BMPs for Y-12.

Accordingly, this Soil Management Plan provides information for project planners to better coordinate their activities with other organizations and programs with a vested interest in soil disturbance activities at Y-12. The information will allow project managers and maintenance personnel to evaluate and anticipate potential contaminant levels that may be present at a proposed soil disturbance site prior to commencement of activities and will allow a more accurate assessment of potential waste management requirements.

\subsection{CONTENT AND USE OF THE PLAN}

This Soil Management Plan is designed and organized to be a user-friendly, visually oriented tool for decision making involving soil excavation or disturbance at Y-12. Where possible, interfaces and processes have been flowcharted for ease of use. Maps and plates illustrating locations of contaminant sources, completed and future RAs, and known occurrence and distribution of key legacy contaminants are provided wherever possible. This plan is not intended to present requirements, procedures, or historical information at a great level of detail; rather, summary information is provided to guide the user in the decision-making process with references to more definitive resources that may be accessed, as needed, for project planning purposes.

The regulatory and programmatic requirements section of this plan is provided to help the user define key considerations, information sources, and points of contact for identifying regulatory and procedural requirements that may apply to soil excavated from a site having a particular regulatory classification or containing certain types of regulated contaminants. Such considerations include identifying the location of the project, regulatory classification of soil contaminants known or determined to be present (e.g., RCRA, TSCA, radiological standards), and if a project site is located within areas governed under CERCLA decision documents, Land Use Control Implementation Plans (LUCIPs), or regulatory permits. Additionally, the Y-12 National Environmental Policy Act of 1969 (NEPA) checklist process and excavation/penetration permit process require multiple information inputs and decision points with respect to project planning.

A summary of legacy contamination in soil and baseline risks for industrial workers is provided to aid the user in assessing potential contaminants and concentrations that may be encountered within a planned soil disturbance area. The summary of legacy contamination is based on the most current compilations of data available, as presented in CERCLA Remedial Investigation (RI) Reports for the Upper East Fork Poplar Creek (UEFPC) and Bear Creek watersheds (DOE 1998, 1997). These documents incorporated available data from historical investigations and compliance programs, as well as new data collected expressly for the purposes of the RIs.

Information on completed environmental response actions taken to date, ongoing response actions, and planned future actions is also compiled. This information includes discussion of land use assumptions 
and remediation goals and, where applicable, the type of action taken and whether long-term performance monitoring is required under the terms of the decision. CERCLA decisions and other governing regulatory permits (e.g., RCRA post-closure permits) are summarized to inform the user of potential restrictions or limitations and land use assumptions that may affect planning decisions for soil disturbances. Identified former and current waste management areas, contaminant point sources, and other areas of known contamination (e.g., Bear Creek floodplain soil) are presented. As an example, soil excavation within a CERCLA AOC or source area may require characterization to determine whether contaminant levels exceed CERCLA remedial goals or other applicable standards, which may merit special considerations for further response actions or soil disposal. Additionally, RCRA post-closure regulations restrict the disturbance of engineered caps and monitoring systems installed as part of closure activities for former treatment, storage, and disposal (TSD) units.

Related to the summary of environmental response actions, a discussion of existing environmental infrastructure constructed as part of the responses is presented where possible (i.e., engineered caps, monitoring systems, and drainage control systems). As noted above, governing decision documents or permits frequently include restrictions or prohibitions for unapproved disturbance or damage to such systems, including the possibility of administrative violations and fines. This information points to the existence of such infrastructure and the awareness of this infrastructure may be incorporated into soil disturbance planning.

Lastly, this plan outlines the Y-12 processes for management and disposition of waste soil upon generation. This section includes a discussion of the flow of regulatory controls and the programmatic contacts/resources for project managers. Considerations for staging the excavated soil to meet site BMPs are provided for the plan user. Summary information is provided relative to characterization requirements; process knowledge (PK) determinations; and guidelines for selection of disposal options based on results of analyses, properties of the excavated material, and acceptance criteria of the disposal facilities. A brief overview of transportation requirements is also provided for soil characterized as low-level and hazardous waste, along with references to programmatic resources who can assist the project manager with identification of transportation requirements.

\subsection{CONFIGURATION MANAGEMENT}

This Soil Management Plan is maintained by the Y-12 ES\&H Division. This document is not subject to a controlled distribution and is not a controlled document. Routine periodic updates (e.g., annual or biannual) are not currently planned by the Y-12 ES\&H Division.

\subsection{ORGANIZATION}

The background, purpose, and content of this Soil Management Plan are presented in Chap. 1. Chapter 2 of this plan includes a discussion of programmatic and regulatory interfaces that may be required during the course of project planning or maintenance activities that involve soil disturbance. Chapter 3 represents a reference source for plan users containing a summary of legacy soil contamination; discussion of historical and future RAs that could affect planned soil disturbances; a summary of regulated units and areas; and a description of current environmental infrastructure that must be considered when planning soil disturbances. Chapter 4 of this plan outlines the regulatory and waste management processes required for managing soil once it is excavated. Appendix A contains the NEPA Review Project Checklist. A summary of identified regulated contaminant source units and non-specific AOCs (e.g., floodplain soils) is contained in Appendix B. Appendix C contains an example of the current Y-12 Excavation Permit. 
04-120(E)/030205 


\section{PROJECT PLANNING}

This chapter outlines project planning and preparatory processes that apply to most soil disturbance projects. These planning processes have been organized, and in some cases proceduralized, into project decision trees. The project decision trees are management tools that provide a consistent, rigorous framework for identifying regulatory or programmatic requirements that may apply to the project. The decision trees also provide indicators for relevant information inputs, critical path decision points, organizational points of contact, and project reporting requirements. The constant revision and change of regulations creates limitations to this and any other management planning tool and requires some level of generalization. Planning for anticipated rule changes is difficult; however, the basic framework for regulatory requirements pertaining to management of contaminated soil has been long established and is expected to remain relatively constant.

The placement of the entire ORR on the National Priorities List (NPL) and a large pool of historical characterization data indicates that all areas within Y-12 may be suspected of containing some level of contamination. Each soil-generating project is addressed independently; however, the basic project planning and preparatory process remains consistent from project to project. The first preference for management of soil within the Y-12 controlled area is staging of soil on the project site, following the Clean Water Act (CWA) BMPs, and placement back into the excavation upon completion (beneficial re-use). However, PK or visual inspections of the project site may indicate that further management of soil is required. Additionally, excess volume then can be beneficially re-used may be generated and require management as waste. Also, during project execution, indications of contamination (e.g., gross staining or strong odors) may be observed once soil excavation or movement begins, which may trigger duties to report and various other cleanup requirements [e.g., underground storage tank (UST) rules]. For soil not subject to beneficial re-use, the specific regulatory and programmatic requirements that apply must be identified in consultation with the Division Environmental Officer and Y-12 Waste Operations Organization personnel within the Y-12 ES\&H Division.

The basic screening process and the key branching programmatic or regulatory decision pathways are flowcharted in this chapter as a series of six decision trees for ease of reference. Text summaries describing the use of the decision trees are presented, along with discussions of key individual decision components for additional clarification. Each of the project decision trees relies, in some part, on information inputs summarized in Chap. 3. The end product of these project decision trees is a set of specific requirements that apply to management of soil generated by the project. Some of these requirements feed into the project waste management protocols, which include additional information inputs and decision points discussed in further detail in Chap. 4.

For completeness and to assist in ongoing efforts to address the nature and extent of contamination at Y-12, a clean soil decision tree was created in addition to those for various regulatory programs. Although no regulatory basis for this decision tree exists (because soil located outside an area that is subject to regulation does not require testing of any kind), prudence would suggest the establishment of some level of assessment. In the clean soil and other decision trees, reference is made to visual surveys and sampling and analysis for indicator parameters. This is a preliminary survey of the conditions associated with an area and is intended to indicate the presence or absence of contamination, not to fully characterize the area, such as would occur under a RCRA corrective action or CERCLA RA.

Where the decision trees refer to sampling and analysis to acquire more detailed knowledge of soil contamination, the intent is not to fully characterize the project site but to determine the presence or absence and concentrations of contamination. When no contamination is known or no prior sampling and

analysis has occurred, the presence or absence of contamination should be documented using a screening 
process consisting of two major steps. First, the location should be reconnoitered to collect information on potential sources of contamination, visibly contaminated soils, and other parameters based on professional judgment and considering the historical use of the area and its proximity to activities that might have impacted the location at some time. Second, soil samples should be collected and analyzed in a laboratory if the initial screening indicates the likely presence of contamination. The extent of sample collection shall be based on the size of the area, what the initial screening shows, and professional judgment. The analysis will provide additional information about the nature of the contamination or will deny that contamination is present. The Clean Area Decision Tree should be followed to completely evaluate these locations.

Generated investigation-derived waste (IDW) should be managed in the same manner as the soil from which it came would be managed. IDW that is generated within an AOC or SWMU, and is not removed from the boundaries of the area, may be returned to the place from which it was removed. IDW that has been removed to a laboratory setting, where it is shown to contain contamination, should be managed in compliance with applicable regulatory programs described in this Plan. IDW that remains at the generation area, but may not be returned to the ground, should be treated, stored, or disposed of in the same manner as is suggested for soil in this Plan. IDW with an undetermined status (i.e., analytical results are pending) should be managed in accordance with Y-12 policies and procedures.

\subsection{MASTER DECISION TREE}

The master decision tree (Fig. 2.1) is used to identify applicable programmatic and regulatory requirements for various situations and provides for selection of standardized, cost-effective, and compliant options for excavated soil management. Soil movement of any kind should be subjected to the decision tree analysis. Five distinct types of contaminated or potentially contaminated soil are expected to be present at Y-12, and decision trees for each type that branch from the master decision tree have been developed to relate the regulatory requirements and options. Proper utilization of the decision trees requires that the user first read the master decision tree and then read through all applicable regulatory program decision trees. Any construction engineering plans developed for use at the facility should consider whether soil will be disturbed as a result of the project execution.

\subsubsection{Project Identification and Location}

Upon project identification, a determination is made regarding the degree of review required under NEPA and Y-12 Comprehensive Environmental Review (Sect. 2.1.1.1). The NEPA/Comprehensive Environmental Review includes review of the project location and will determine if additional review is needed to determined if the project location is subject to regulatory programs or if additional screening is required (e.g., CERCLA screening). Field verification of current site conditions is recommended. The NEPA/Comprehensive Environmental Review produces a set of applicable environmental protection BMPs, inclusive of soil management.

Once it is determined that a candidate project will involve soil management, a CERCLA screening process (Sect. 2.1.1.2) is conducted to identify if the project location is within an area for which actions pursuant to CERCLA or RCRA post-closure have been conducted or are planned. If the project will not overlap areas subject to a regulatory program, the clean soil decision tree should be reviewed. If the project will involve soil management in an area subject to a regulatory program, an alternative location should be sought. If this is accomplished, the clean soil decision tree should be reviewed to identify management requirements for soil in areas where there is no suspected contamination. 


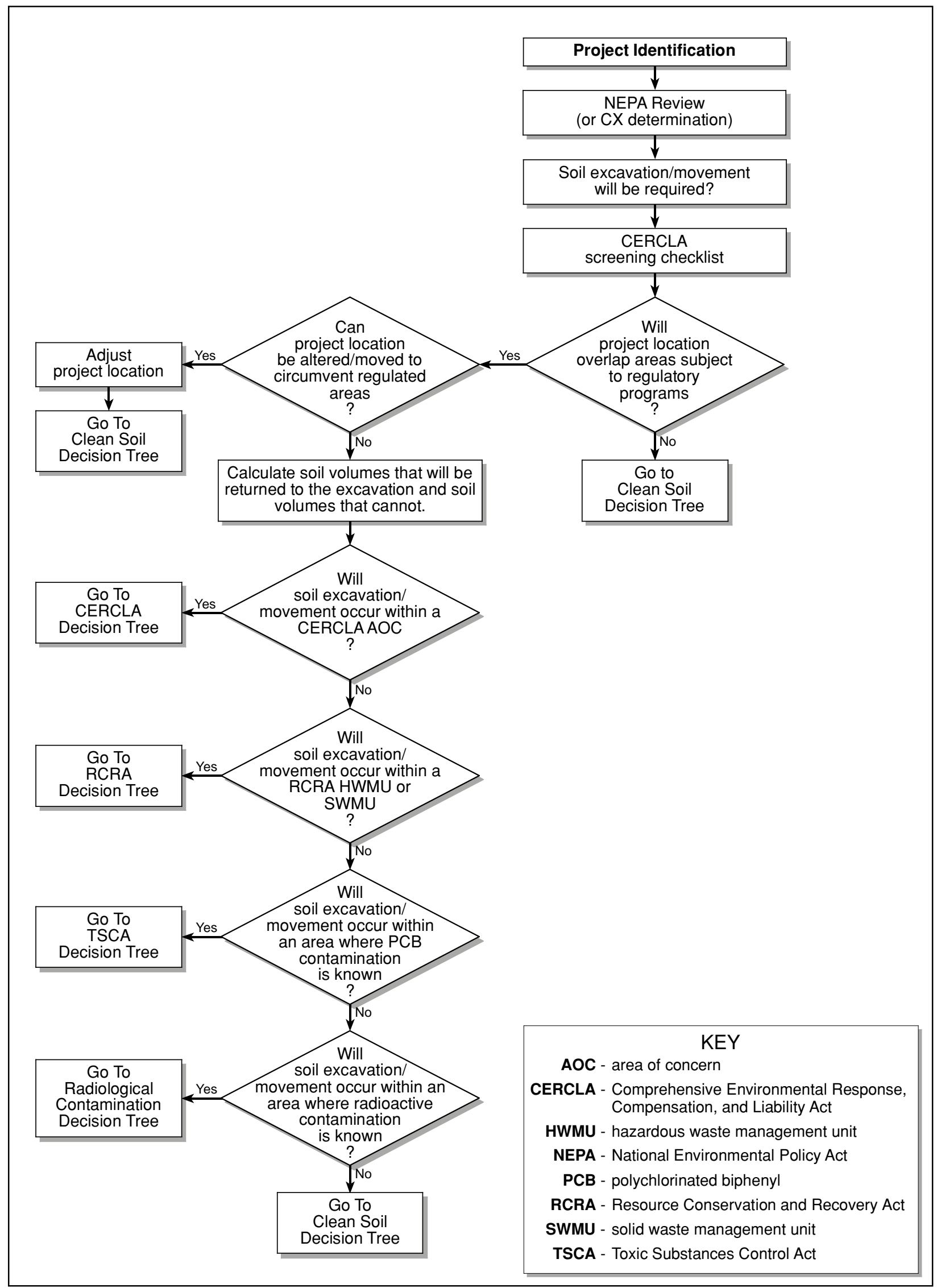

Fig. 2.1. Master decision tree.

G04-0128 flowchart 4 


\subsubsection{Y-12 NEPA/Comprehensive Environmental Review}

The NEPA/Comprehensive Environmental Review process is conducted by the Y-12 ES\&H Division and has been proceduralized in the form of a NEPA checklist (Appendix A). Some types of routine maintenance and environmental compliance activities have been categorically reviewed and are covered under a Categorical Exclusion (CX; CX-GEN-011); thus, specific projects may be exempted from the full NEPA review should they fall under the purview of the CX. However, the CX includes provisions for individual project NEPA review should the action have the potential to result in an unusual or minor impact to the environment.

The NEPA review process is a broad-based review of

- $\quad$ applicable environmental regulations,

- potential environmental impacts of a proposed activity,

- $\quad$ potential impacts on facility infrastructure and utilities,

- $\quad$ potential disturbances of hazardous or radiologically contaminated materials (e.g., soil, groundwater, etc.),

- $\quad$ waste generation and handling, and

- $\quad$ potential waste minimization BMPs that may be applied.

In terms of direct applicability to soil disturbances, the NEPA review forces an examination of the regulatory implications of a planned activity, an examination of the presence of legacy contamination and source areas within the project footprint, and initiates the proper oversight and interfaces required for management and disposition of any contaminated soil that may be generated. Optimally, the NEPA review is conducted simultaneously with the CERCLA screening process because both processes rely on several of the same information inputs, which are supported by Chap. 3 of this Plan (e.g., locations of remedial response actions, legacy contaminants, source areas, and environmental infrastructure).

The end product of the NEPA review is a set of applicable environmental protection BMPs and requirements for project implementation, including soil management. The NEPA review product helps to identify regulatory requirements that could potentially apply to soil that is not be eligible for beneficial re-use (e.g., returned to the excavation). The review further denotes whether new permits, modified permits, or other notifications to regulatory agencies may be required prior to soil disturbance activities (e.g., stormwater permits, RCRA post-closure permit notifications, etc.). The review product also provides indicators as to the need for excavation/penetration permits and industrial hygiene (IH) review or support on the project.

\subsubsection{Y-12 CERCLA screening process}

The CERCLA screening process focuses on:

- $\quad$ legacy contaminants that may be present in soil and associated remediation goals,

- $\quad$ project impacts on planned future RAs under CERCLA, 
- $\quad$ project relationship and potential impacts with respect to the land use basis for current and planned future CERCLA decisions, and

- $\quad$ potential project impacts on contaminant migration patterns (i.e., groundwater and surface water).

Although not specifically a soil management issue, the screening process also addresses demolition of contaminated buildings with respect to assessing the potential for releases of contaminants to the environment. If such facility demolition activities may require excavation and management of adjacent soil that becomes contaminated, then the requirements of this Soil Management Plan are applicable.

Figure 2.2 illustrates the overall Y-12 CERCLA screening process for soil disturbance activities. Table 2.1 lists the information inputs into the initial decision point as to whether or not CERCLA oversight may be required. Summary data for most of these information inputs are presented in Chap. 3, including overviews of legacy contamination, current and future planned RAs, and the land use basis. If a decision is reached wherein the project may require additional CERCLA oversight, a written project summary is compiled for more detailed evaluation by NNSA and FFA project managers as to whether CERCLA oversight is required. Upon reaching an affirmative decision point regarding CERCLA oversight, specific requirements and documentation needs with respect to FFA and reporting mechanisms for communicating with FFA managers are established. The decision pathway for soil management within a CERCLA AOC is further discussed below. For negative decisions with respect to CERCLA oversight, the project may be subject to other requirements of other environmental regulations.

\subsubsection{Soil Management in Areas Subject to Regulatory Programs}

Through review of the information inputs (e.g., maps, data, permits, decision documents, etc.) for the NEPA/Comprehensive Environmental Review and the CERCLA screening, a determination is made that the project will overlap areas subject to regulatory programs. Where this is the case, the master decision tree pathway is followed through to the appropriate programmatic or regulatory-specific decision trees for additional planning considerations before continuing with the planned project. Each of the specific decision trees is described in further detail in Sects. 2.2 through 2.6.

In many cases where soil will be subject to regulatory programs, the option of soil replacement or beneficial re-use (returned to the excavation) will be available. In cases where the entire volume of soil to be excavated cannot be accommodated in a beneficial re-use scenario, the calculated volume of soil not to be returned to its original location will be subject to different management scenarios under different regulatory programs. BMPs and other applicable requirements of CWA regulations will be specified as part of the NEPA/Comprehensive Environmental Review to ensure the control of erosion or runoff due to contaminant migration. Additional information on BMPs and limitations on beneficial re-use is provided in Chap. 4.

\subsubsection{Other Program and Regulatory Requirements Impacting Soil Excavation and Movement}

Other regulatory programs, although outside of the specific scope of this Plan, may also pertain to a soil disturbance project and are included for completeness.

\section{Classified Materials}

Special requirements for the management of classified materials may apply in addition to 


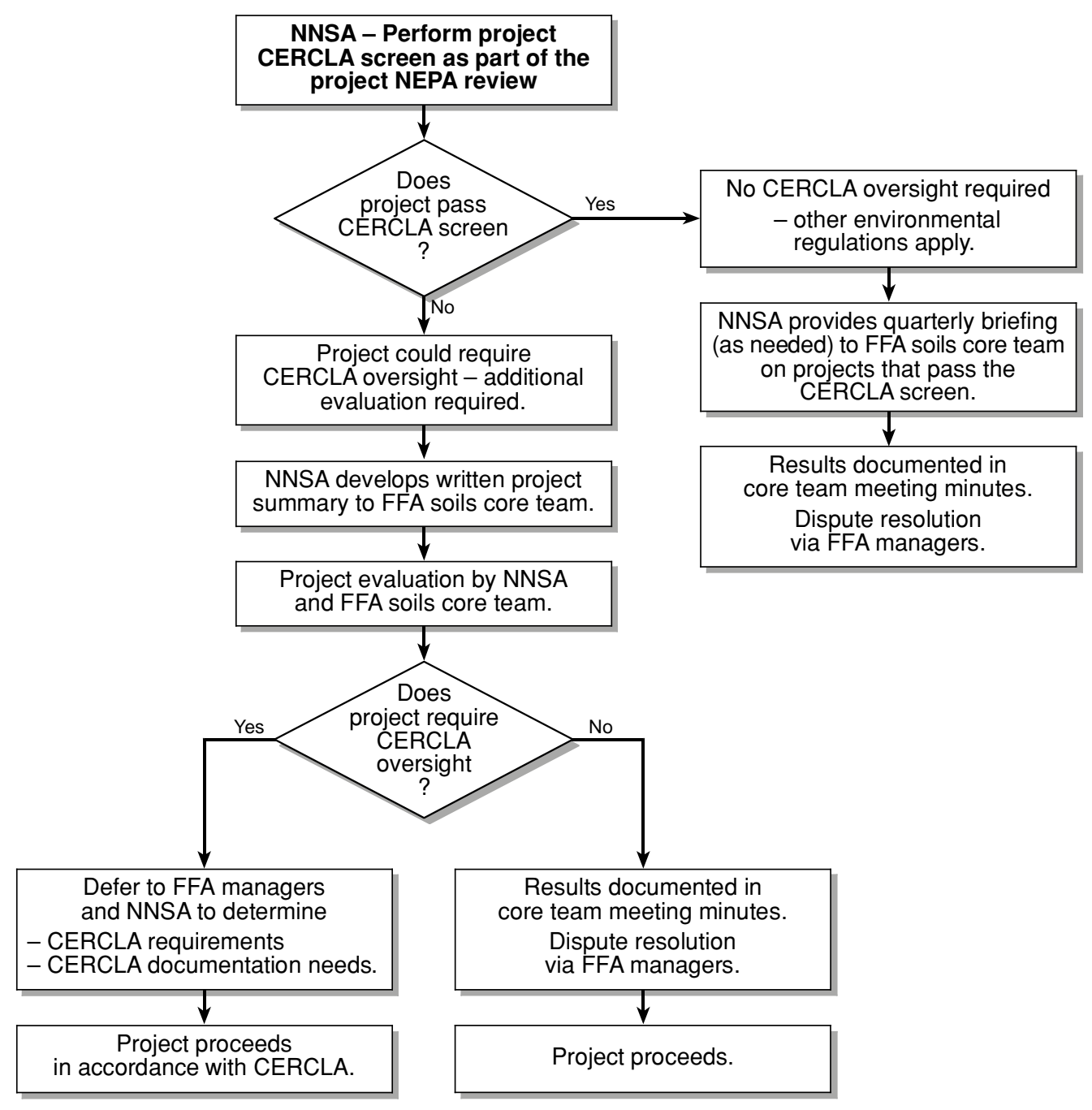

\section{KEY}

CERCLA - Comprehensive Environmental Response, Compensation, and Liability Act

FFA - Federal Facilities Agreement

NEPA - National Environmental Policy Act

NNSA - National Nuclear Security Agency

Fig. 2.2. Y-12 National Security Complex soil disturbance project CERCLA screening process. 
Table 2.1. Y-12 National Security Complex soil disturbance project CERCLA Screening Checklist

1. Impact on Future Planned Remedial Action: Evaluation whether the proposed project will interfere with existing or planned environmental remediation actions at the Y-12 National Security Complex other than soil (which is addressed in checklist item number 2, below).

Are any Federal Facilities Agreement Appendix C-listed remediation sites/facilities within the boundary of the proposed project footprint (excluding soil contamination areas, which is addressed in item 2, below)?

Will the proposed project adversely impair planned groundwater remediation activities?

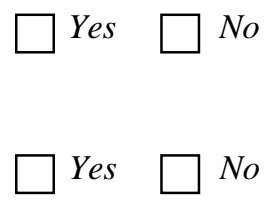

2. Soil Contamination Evaluation: Evaluation whether the proposed project will disturb areas where soil contaminants are above soil remediation criteria as defined in the Upper East Fork Poplar Creek (UEFPC) Soil and Scrapyard Focused Facility Study.

Does the proposed project footprint encompass any identified soil contamination "hotspot," $\square$ Yes $\square$ No as identified in the UEFPC Soils and Scrapyard Focused Feasibility Study?

Note: Any project-specific soil sampling results that show soil contamination above levels established in the UEFPC Soil and Scrapyard Focused Feasibility Study will require further consultation with regulatory agencies to identify CERCLA requirements.

3. Changes to Planned Future Land Use: Evaluation whether the proposed project will change the planned future land use of the site from continued long-term industrial use by the federal government for defense-related purposes.

Will the proposed project involve change of existing land use by the U. S. Federal $\square$ Yes $\square$ No Government for industrial defense-related purposes?

4. Impact on Contaminant Migration: Evaluation whether the proposed project will potentially change contaminant migration due to changes in surface water or groundwater flow.

Will the proposed project alter surface water or groundwater flow within the Y-12 National Security Complex such that the potential exists to adversely impact migration of legacy contamination?

5. Building Demolition Only_Site Characterization Evaluation: Evaluation whether the proposed building demolition will demolish facilities that are process contaminated with hazardous and/or radioactive materials such that a potential threat of a release to the environment exists if the demolition is not accomplished with proper engineering controls.

Has the facility to be demolished been known to process hazardous or radioactive materials in uncontained equipment and/or containers (i.e., excluding material storage in closed containers/tanks, process operations in glove boxes, or other contained equipment, etc.)?

Has the facility to be demolished been a hazard category I, II, or III Nuclear Facility or a Chemically Hazardous Facility, as defined by the Y-12 Facility Safety Program Description?

Has the operation of the facility included any history of hazardous substance $\square$ Yes $\square$ No spills/releases?

Note: Any project-specific site characterization sampling results that show widespread contamination of hazardous or radioactive materials throughout the facility will require further review to determine if existing process knowledge information on historical use is accurate.

Note: Answering "Yes" to any of the CERCLA screening questions will require further consultation with regulatory agencies to identify CERCLA requirements and establish CERCLA documentation requirements. 
requirements provided in the program-specific decision trees. Prior to project work in areas that potentially contain classified material, interfaces with the appropriate Y-12 classification and security organizations must be initiated and relevant requirements incorporated into soil management planning.

\section{OSHA or RADCON Requirements}

Occupational Safety and Health Administration (OSHA) and/or Radiological Control (RADCON) requirements may dictate the use of personal protection equipment (PPE) and/or engineered controls during soil disturbance. For example, soil movement within a regulated area [e.g., an operable unit (OU)] must be carried out by workers trained in accordance with the OSHA Hazard Waste Operations and Emergency Response Standard [29 Code of Federal Regulations (CFR) 1910.120(e)]. Such requirements are dictated through Y-12 Health and Safety Procedures Y73-378, Safe Conduct of Excavation/Penetration Work, and Y73-164, Subcontractor Environmental Safety and Health Management, which mandate health and safety organizational evaluation of planned activities involving excavation or disturbance of soil, as well as other types of work activities. The mechanism for this organizational evaluation is the Activity Hazard Analysis (AHA). The AHA serves to document potential physical, chemical, and radiological hazards that may be encountered during the course of work. The AHA also identifies the appropriate engineering and administrative controls and monitoring activities (environmental and personnel monitoring) that are to be implemented to mitigate those hazards.

\section{Excavation Permit Process}

The excavation permit review process is mandatory for all planned soil disturbances at Y-12. Excavations that may penetrate $1 \mathrm{ft}$ or deeper below ground surface require an excavation permit. The process also triggers notification to the RADCON organization (regardless of whether an excavation permit is required) prior to the start of work. The process is initiated through the Engineering Organization and documented in accordance with Y-12 Engineering Procedure Y17-69-410, Initiation, Review, and Termination of Excavation/Penetration Permits. Responsibility for initiating and obtaining a completed excavation permit (Appendix C) prior to the start of work lies with the project manager or designee. The excavation permit review focuses on the presence of physical plant infrastructure, which, if disturbed, could have negative safety or environmental consequences or impact facility operations or security. This Soil Management Plan does not attempt to provide the requisite information for completing excavation permits. The excavation permit review does not specifically encompass environmental remediation infrastructure (e.g., monitoring systems, engineered caps, drainage controls, etc.). Provisions for these types of infrastructure are included as part of the CERCLA process review and, in part, the NEPA checklist review. Summary information on environmental remediation infrastructure is contained in Sects. 3.1 and 3.4, respectively.

\subsection{USING THE COMPREHENSIVE ENVIRONMENTAL RESPONSE, COMPENSATION, AND LIABILITY ACT DECISION TREE}

Projects involving soil management will be impacted by CERCLA if they fall into a designated regulatory area such as an AOC or an OU for which a remedial decision has been completed, is ongoing, or is planned. This determination is made through the CERCLA project screening process. Although the large majority of investigative activities under CERCLA within the Y-12 area of responsibility have been completed, portions of AOCs that may be slated for further characterization also must be considered. Because of the broad definitions of AOCs and OUs, many areas within Y-12 are potentially subject to the rules associated with operations within a CERCLA AOC even though the project may not be located within a specific source area (e.g., UEFPC soil and scrapyard, Sect. 3.1.2). The specific decision tree addressing soil management within a CERCLA AOC is provided in Fig. 2.3. 


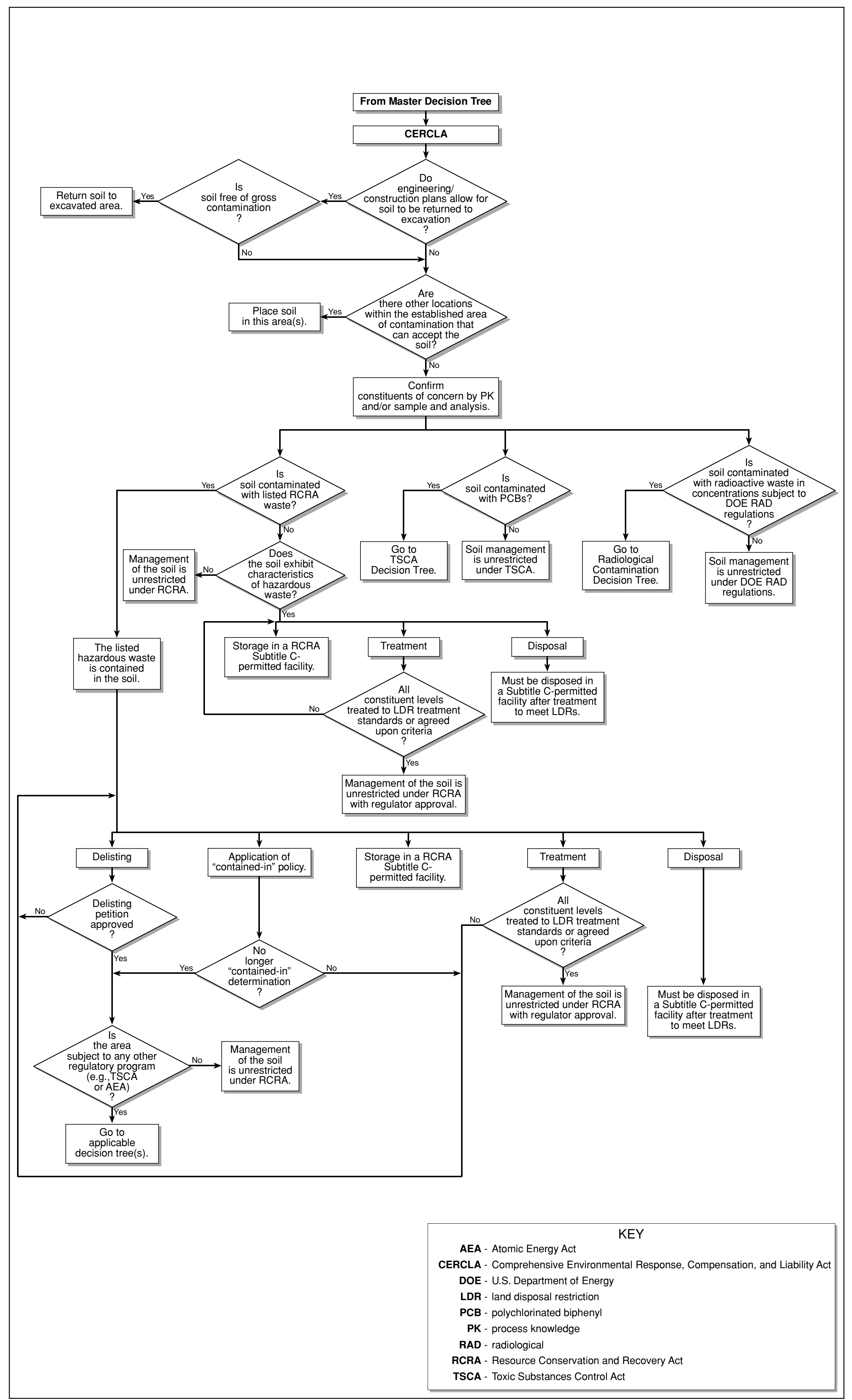

Fig. 2.3. Decision tree for compliance with CERCLA. 


\subsubsection{Soil Disposition}

Specific project construction and engineering plans shall be reviewed to assess the soil volumes to be excavated, the required depths of the excavations, and the total displacement that will occur because of the project.

\subsubsection{Beneficial re-use}

Soil excavated as part of an RA within a CERCLA AOC may be returned to its excavation point, and the return of the soil is not considered to be placement when moving soil within a unit [55 Federal Register (FR) 8758]. The concept of placement triggers other regulatory controls, namely RCRA land disposal restriction (LDR) requirements. The U. S. Environmental Protection Agency (EPA) interprets placement to mean putting hazardous wastes into one of these units, not the movement of waste within the unit (55 FR 8759, 51 FR 40577, and 54 FR 41566). In 2002, EPA promulgated the Corrective Action Management Unit (CAMU) Rule through which beneficial re-use or soil replacement may be extended to multiple AOCs subject to requesting and obtaining a CAMU determination. The preamble to the NCP further clarifies that normal earthmoving and grading operations within a unit would not be considered placement and thus would not trigger LDRs (55 FR 8759-60). Soil excavated within a CERCLA AOC during a project that is not part of an RA (e.g., maintenance, construction) may not be subject to the conditions above and regulatory determination should be made as part of project planning.

\subsubsection{Soil replacement within the designated unit}

Soil that has been excavated during an RA from within a CERCLA AOC and that cannot be beneficially re-used due to engineering constraints may be placed in other areas within the same AOC (53 FR 51444-5). If the soil volume is greater than can be accommodated in an AOC, the excess soil must be managed as a contaminated soil and is subject to established regulatory controls. Soil that is not to be returned to the unit should undergo sampling and analysis either to confirm the constituents of concern (COCs) or to make a hazardous waste determination and identify treatment requirements for LDRs. As noted for beneficial re-use, a regulatory determination should be made for other types of projects within an AOC.

\subsubsection{Soil That Cannot be Managed Within the Unit}

For soil that cannot be returned to the excavation site or remain within the boundary of the AOC, other management is required. Once confirmatory sampling and analysis are performed, applicable regulatory programs must be identified and followed.

\subsubsection{Soil contaminated with RCRA hazardous waste}

When doubt exists regarding the RCRA status of a waste, conservative assumptions should be made in favor of RCRA jurisdiction. Sources of COCs should be identified, but if this information is not available, the soil should be assessed for likely contamination (e.g., PK determination) and for hazardous waste characteristics [defined at TN Rule 1200-1-11.02(3)]. If the soil is determined to be contaminated with listed constituents, and if the process that released listed hazardous waste can be identified and linked to the contamination present in the soil, the listing must apply. Before attempting to manage soil contaminated with RCRA hazardous waste, the RCRA decision tree and waste management requirements of Chap. 4 should be reviewed. 


\subsubsection{Soil contaminated with PCBs}

When sampling and analysis results show PCBs, the contamination source must be identified. TSCA regulatory requirements for PCBs vary depending on the date of the spill, the concentration of the PCB material contaminating the soil, and the accessibility of the contamination. Before attempting to manage soil contaminated with PCBs, the PCB decision tree should be reviewed.

\subsubsection{Soil that contains low-level radioactive material}

When sampling and analysis results show levels of radioactivity above designated background levels, certain steps must be taken. Before attempting to manage soil considered or suspected of being low-level radioactive waste or low-level mixed radioactive waste, the low-level radioactive waste decision tree should be reviewed.

\subsection{USING THE RESOURCE CONSERVATION AND RECOVERY ACT DECISION TREE}

Figure 2.4 illustrates the decision tree for managing soil under RCRA regulatory drivers. If the soil disturbance project falls into any of the following regulatory areas, RCRA requirements potentially apply:

- Hazardous waste management unit (HWMU) (TN Rule 1200-1-11);

- $\quad$ SWMU (50 FR 28712, 55 FR 30808);

- $\quad$ Area of suspected contamination, listed waste; and

- $\quad$ Area of suspected contamination, characteristic waste.

Under Subtitle C of RCRA, hazardous wastes, as defined in TN Rule 1200-1-11.02(1)(c), are waste streams that are either listed in TN Rule 1200-1-11.02(4) or exhibit a characteristic of hazardous waste described in TN Rule 1200-1-11.02(3). Appendix 02/E to TN Rule 1200-1-11 lists hazardous constituents, sometimes called COCs, which are associated with the hazardous waste listings. Presence of Appendix 02/E constituents in a waste does not automatically designate that waste as a RCRA hazardous waste, i.e., listed or characteristic. Solid wastes that are not listed as hazardous wastes and do not exhibit a characteristic of hazardous waste may contain hazardous constituents. The uncontrolled release of hazardous constituents from SWMUs, via solid waste, is subject to corrective action under RCRA Sect. 3004(u).

\subsubsection{Soil Movement Within a Hazardous Waste Management Unit}

A HWMU is defined as a contiguous area on or in which hazardous waste is placed, or the largest area on or in which there is significant likelihood of mixing hazardous waste constituents in the same area. Examples of HWMUs include hazardous waste incinerators, surface impoundments, or tanks and associated piping. HWMUs are subject to RCRA permitting requirements. Active permitted HWMUs at Y-12 are precluded from any soil disturbance other than that required for unit construction or maintenance needs. Seven former HWMUs at Y-12 (see Sect. 3.1) are closed and in post-closure status; soil disturbance within these areas is prohibited without prior approval of the Tennessee Department of Environment and Conservation (TDEC). Under the terms of the RCRA post-closure permits for the seven former HWMUs, any required corrective actions are deferred to the CERCLA process. Various historical characterization data are available for the closed HWMUs within Y-12; these data have been incorporated into the CERCLA process, along with newer characterization data and are available for determining disposition requirements for any soil that may require excavation within the units. 
04-120(E)/030205 


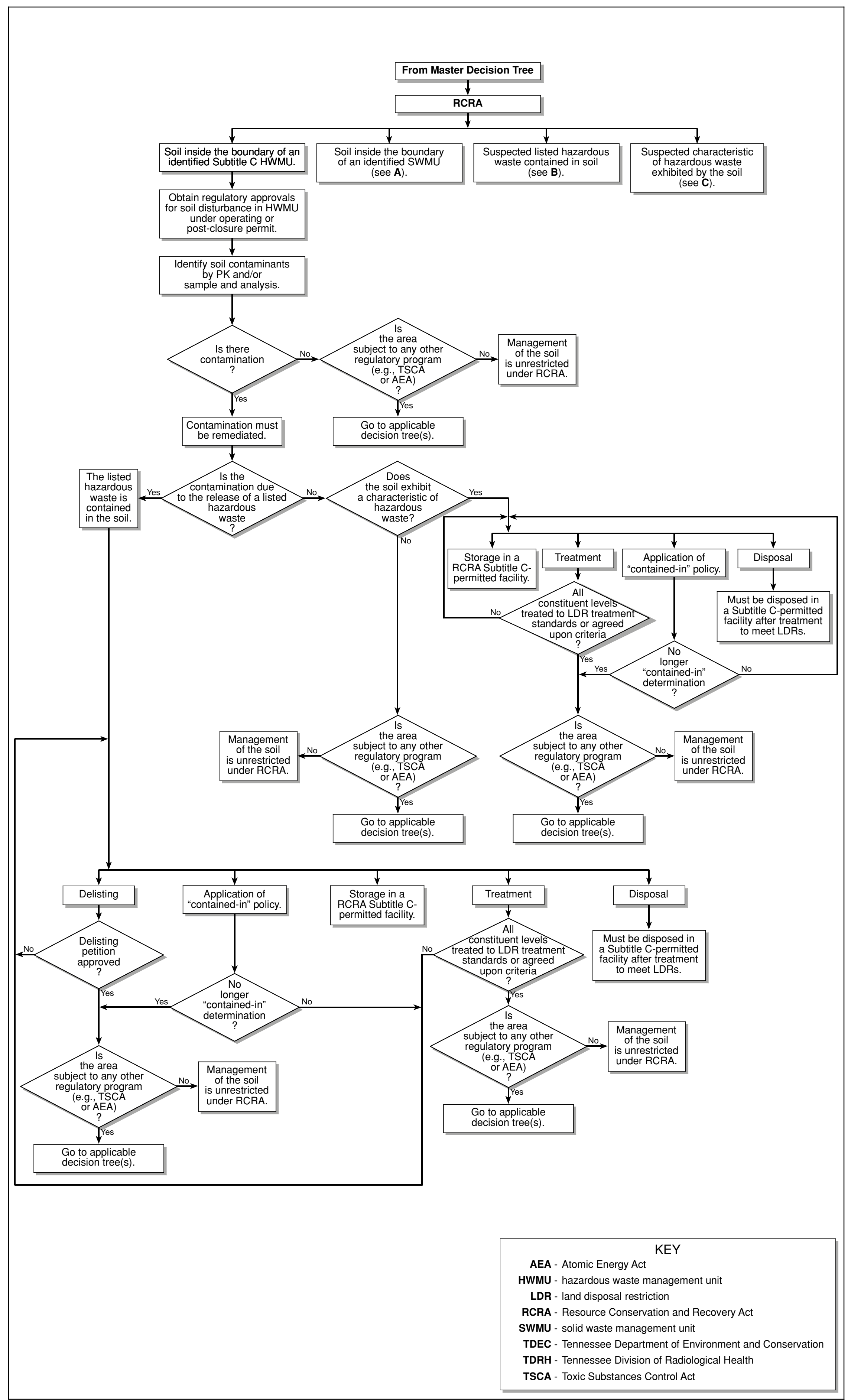




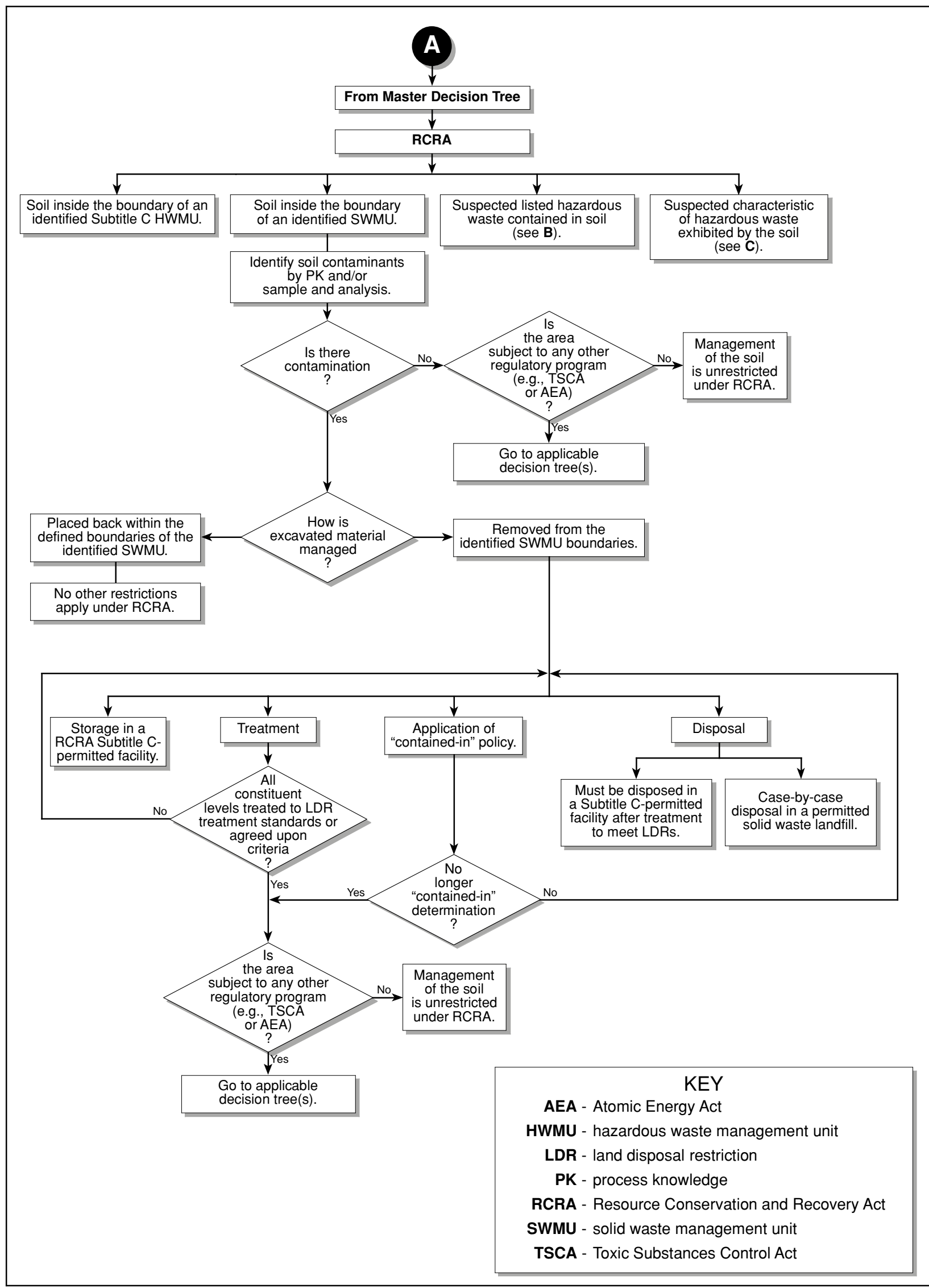

Fig. 2.4. (continued)

G04-0128 flowchart 7 B 
Y/SUB/92-28B99923C-Y05, Rev. 1

FINAL

Copy 1

\title{
SOIL MANAGEMENT PLAN FOR THE \\ OAK RIDGE Y-12 NATIONAL SECURITY COMPLEX OAK RIDGE, TENNESSEE
}

Issue Date: March 2005

Prepared by

Science Applications International Corporation 151 Lafayette Drive Oak Ridge, Tennessee 37831 Under Subcontract Number 4300031991

for the

Environmental Compliance Department Environment, Safety, and Health Division Y-12 National Security Complex

Oak Ridge, Tennessee 37831

\author{
Managed by \\ BWXT Y-12, L.L.C. \\ for the
}

U. S. Department of Energy

National Nuclear Security Administration

Under Contract No. DE-AC05-00OR22800 


\section{DISCLAIMER}

This report was prepared as an account of work sponsored by an agency of the United States Government. Neither the United States Government nor any agency thereof, nor any of their employees, makes any warranty, express or implied, or assumes any legal liability or responsibility for the accuracy, completeness, or usefulness of any information, apparatus, product, or process disclosed, or represents that its use would not infringe privately owned rights. Reference herein to any specific commercial product, process, or service by trade name, trademark, manufacturer, or otherwise, does not necessarily constitute or imply its endorsement, recommendation, or favoring of the United States Government or any agency thereof. The views and opinions of authors expressed herein do not necessarily state or reflect those of the United States Government or any agency thereof. 


\section{SCIENCE APPLICATIONS INTERNATIONAL CORPORATION}

contributed to the preparation of this document and should not be considered an eligible contractor for its review. 


\title{
SOIL MANAGEMENT PLAN FOR THE OAK RIDGE Y-12 NATIONAL SECURITY COMPLEX OAK RIDGE, TENNESSEE
}

\author{
Issue Date: March 2005
}

Prepared by

Science Applications International Corporation

151 Lafayette Drive

Oak Ridge, Tennessee 37831

Under Subcontract Number 4300031991

for the

Environmental Compliance Department Environment, Safety, and Health Division Y-12 National Security Complex

Oak Ridge, Tennessee 37831

\author{
Managed by \\ BWXT Y-12, L.L.C. \\ for the
}

U. S. Department of Energy

National Nuclear Security Administration

Under Contract No. DE-AC05-00OR22800 



\section{CONTENTS}

TABLES

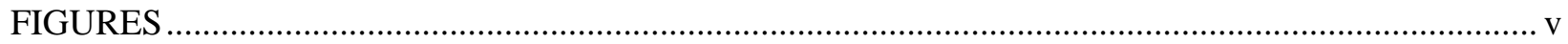

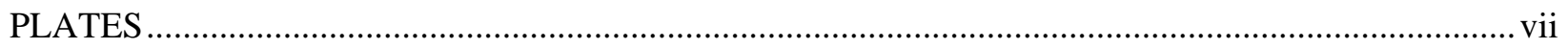

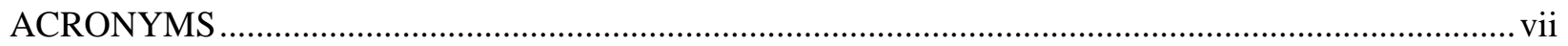

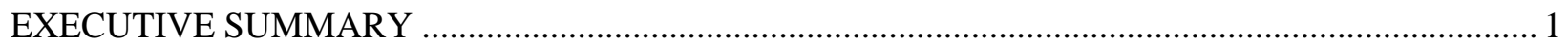

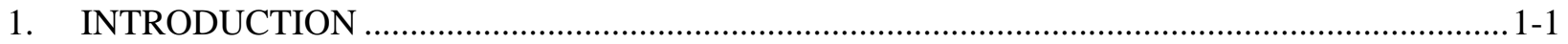

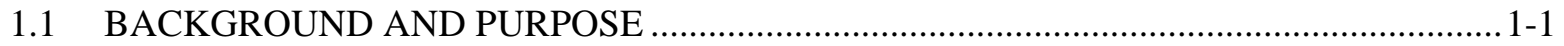

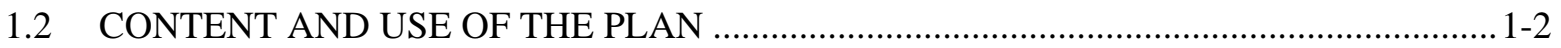

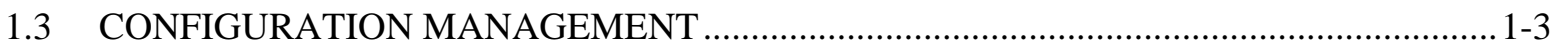

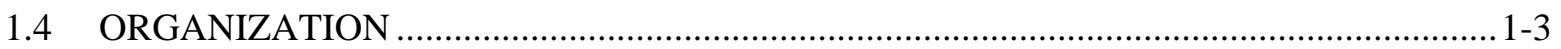

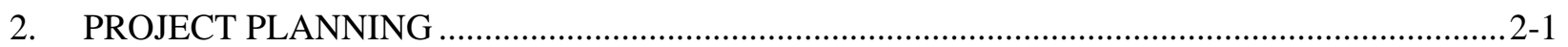

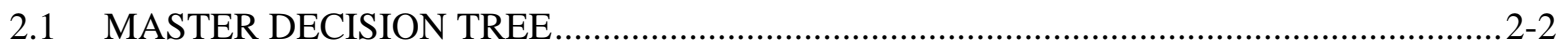

2.1.1 Project Identification and Location ...................................................................... 2-2

2.1.2 Soil Management in Areas Subject to Regulatory Programs ...................................2-5

2.1.3 Other Program and Regulatory Requirements Impacting Soil Excavation and

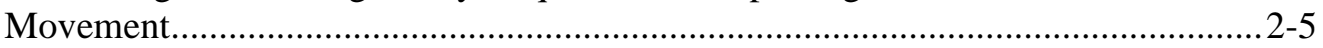

2.2 USING THE COMPREHENSIVE ENVIRONMENTAL RESPONSE, COMPENSATION, AND LIABILITY ACT DECISION TREE ....................................... $2-8$

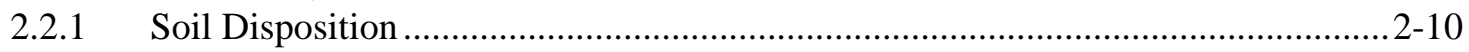

2.2.2 Soil That Cannot be Managed Within the Unit ....................................................2-10

2.3 USING THE RESOURCE CONSERVATION AND RECOVERY ACT DECISION

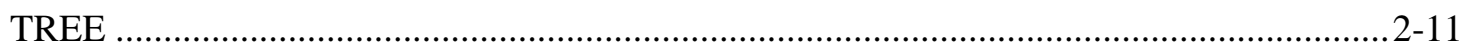

2.3.1 Soil Movement Within a Hazardous Waste Management Unit ...............................2-11

2.3.2 Soil Management Within a Solid Waste Management Unit....................................2-17

2.3.3 Area of Suspected Contamination, Listed Hazardous Waste ................................... 2-18

2.3.4 Area of Suspected Contamination, Characteristic Waste .......................................2-18

2.4 USING THE TOXIC SUBSTANCES CONTROL ACT DECISION TREE.......................2-19

2.4.1 Polychlorinated Biphenyl Contamination Due to Unknown Sources .....................2-19

2.4.2 Polychlorinated Biphenyl Contamination Due to Pre-1978 Spills .........................2-22

2.4.3 Releases of Polychlorinated Biphenyls Due to Post-1978 Spills ...........................2-22

2.5 USING THE ATOMIC ENERGY ACT DECISION TREE ..........................................2-22

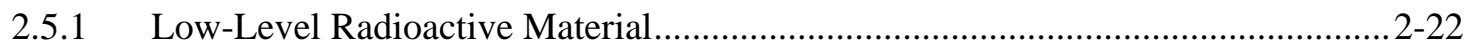

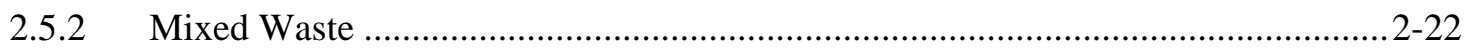

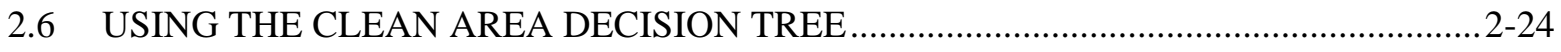

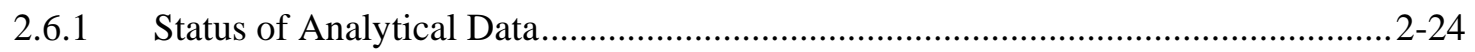

3. LEGACY CONTAMINATION AND ENVIRONMENTAL INFRASTRUCTURE .......................3-1

3.1 HISTORICAL RESPONSE ACTIONS AND COMPREHENSIVE ENVIRONMENTAL RESPONSE, COMPENSATION, AND LIABILITY ACT

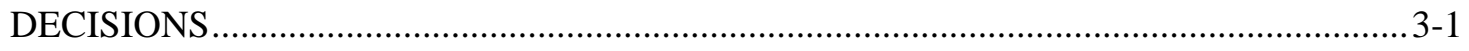

3.1.1 Historical Response Actions .......................................................................... 3-2

3.1.2 Comprehensive Environmental Response, Compensation, and Liability Act

Actions in the Upper East Fork Poplar Creek Watershed (Y-12 National

Security Complex)..............................................................................................

3.1.3 Comprehensive Environmental Response, Compensation, and Liability Act Actions in the Bear Creek Watershed.... 
3.1.4 Comprehensive Environmental Response, Compensation, and Liability Act Actions in the Chestnut Ridge Administrative Area ............................................ 3-17

3.2 SOLID WASTE MANAGEMENT UNITS ............................................................... 3-23

3.2.1 Upper East Fork Poplar Creek Watershed (the Y-12 National Security

Complex).....

3.2.2 Bear Creek Watershed ................................................................................ 3-23

3.2.3 Chestnut Ridge Administrative Area ….............................................................. 3-24

3.3 SUMMARY OF ENVIRONMENTAL CONTAMINATION IN SOIL ............................ 3-24

3.3.1 Upper East Fork Poplar Creek Watershed....................................................... 3-24

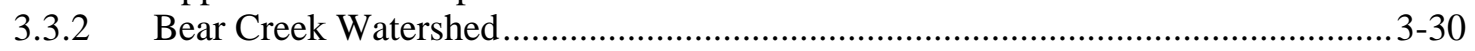

3.3.3 Chestnut Ridge Administrative Area ...................................................................

3.4 CURRENT AND FUTURE ENVIRONMENTAL INFRASTRUCTURE ..........................3-43

3.4.1 Upper East Fork Poplar Creek Watershed (the Y-12 National Security

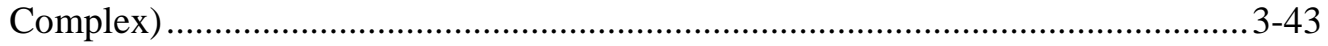

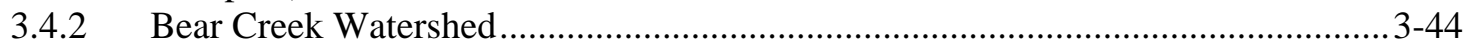

3.4.3 Chestnut Ridge Administrative Area ................................................................... $4-44$

4. WASTE MANAGEMENT PROTOCOLS AND PROCEDURES ….......................................

4.1 OVERVIEW OF THE SOIL DISPOSITION PROCESS .....................................................4-1

4.2 ON-SITE MANAGEMENT OF EXCAVATED SOILS: REGULATORY REQUIREMENTS AND BEST MANAGEMENT PRACTICES ........................................4-1

4.2.1 Clean Water Act Best Management Practices ...................................................... 4-1

4.2.2 Contaminated Soil Regulatory Requirements and Best Management Practices ....... 4-2

4.3 CHARACTERIZATION OF EXCAVATED SOIL FOR DISPOSITION ...........................4-3

4.4 ESTABLISHING A WASTE DISPOSITION PATHWAY ….............................................4-4

4.4.1 On-site Disposal Options and Associated Waste Acceptance Criteria......................4-4

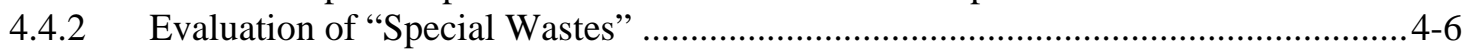

4.4.3 Classified Waste Disposal .................................................................................. 4-7

4.4.4 Class IV Facility Construction/Demolition Waste Disposal ................................... 4-7

4.4.5 On-site Construction/Demolition Spoil Areas........................................................4-7

4.4.6 Oak Ridge Reservation Environmental Management Waste Management

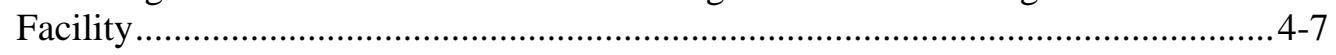

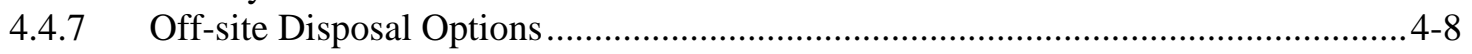

4.5 TRANSPORTATION REQUIREMENTS ................................................................. $4-8$

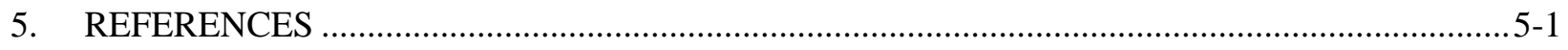

APPENDIX A BWXT Y-12, L.L.C. NATIONAL ENVIRONMENTAL POLICY ACT REVIEW

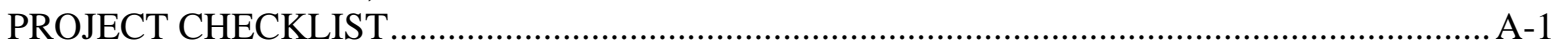

APPENDIX B SOURCE AREA SUMMARY INFORMATION FROM REMEDIAL ACTION INFORMATION MANAGEMENT SYSTEM (RAIMS) ........................................................ B-1

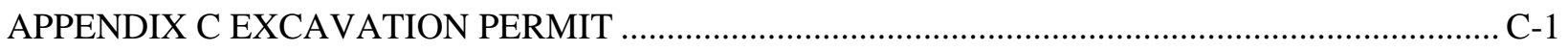

APPENDIX D POTENTIAL SOURCE AREAS FOR RADIOACTIVE SOIL CONTAMINATION ... D-1 


\section{TABLES}

2.1 Y-12 National Security Complex soil disturbance project CERCLA Screening Checklist.............2-7

3.1 RCRA post-closure status for former treatment, storage, and disposal units at Y-12 ..................3-3

3.2 Summary of completed and ongoing CERCLA response actions in the UEFPC Watershed ..........3-6

3.3 Primary actions under a Soil Removal Alternative, UEFPC focused feasibility study .................3-14

3.4 Summary of completed and ongoing CERCLA response actions in the Bear Creek

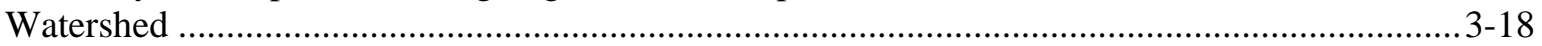

3.5 Summary of completed and ongoing CERCLA response actions in the Chestnut Ridge

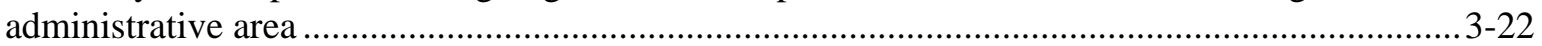

3.6 Legacy waste management units in the Bear Creek Hydrogeologic Regime ..............................3-34

3.7 Legacy and active waste management units in the Chestnut Ridge Hydrogeologic Regime .........3-41

\section{FIGURES}

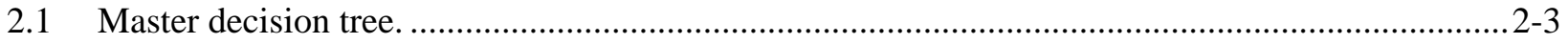

2.2 Y-12 National Security Complex soil disturbance project CERCLA screening process.................2-6

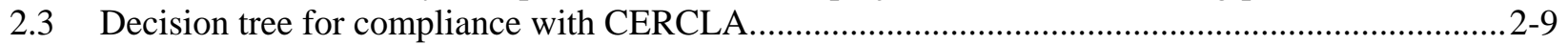

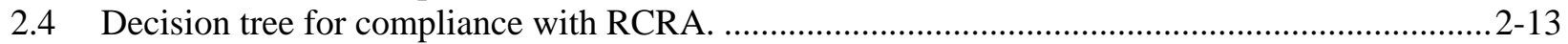

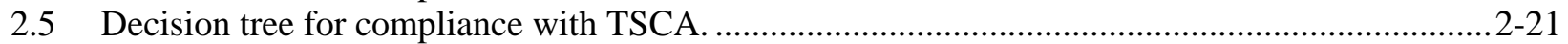

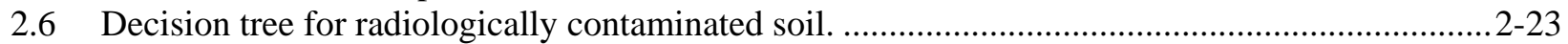

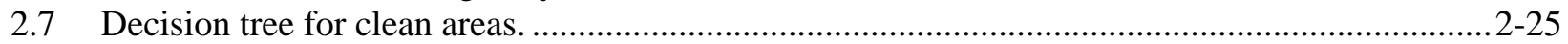

3.1 Locations of RCRA TSD units in post-closure status at Y-12 and waste management units in the Chestnut Ridge administrative area. ..............................................................................

3.2 Locations of former RMPE actions and completed and ongoing CERCLA response actions in the UEFPC Watershed and Chestnut Ridge administrative area. ........................................... 3-11

3.3 Estimated areas of soil excavation in the western Y-12 area under a soil removal alternative, UEFPC Focused Feasibility Study.

3.4 Estimated areas of soil excavation in the eastern Y-12 area under a soil removal alternative, UEFPC Focused Feasibility Study.....

3.5 Locations of completed and ongoing CERCLA response actions in the Bear Creek

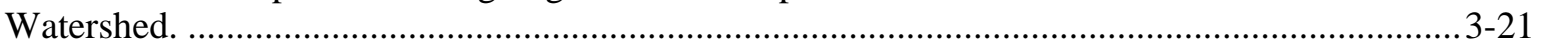

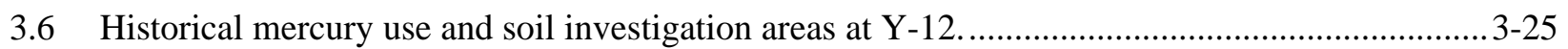

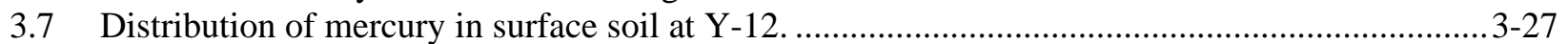

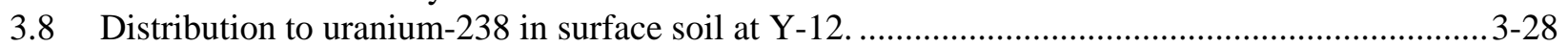

3.9 Distribution of total PCBs in surface soil at Y-12.................................................................. 3-29

3.10 Summary of surface soil risks for the unprotected industrial worker and site-specific soils data locations for the UEFPC Watershed............................................................................. 3-31

3.11 Y-12 radiological characterization summary - UEFPC Watershed and Chestnut Ridge

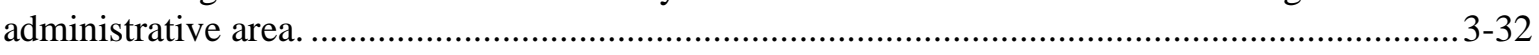

3.12 Distribution of risks to hypothetical industrial workers and unprotected maintenance workers in Bear Creek Valley................................................................................................. 3-35

3.13 Distribution of cadmium in Bear Creek floodplain soils and sediments.....................................3-37

3.14 Distribution of uranium-238 in Bear Creek floodplain soils and sediments...............................3-38

3.15 Distribution of total PCBs in Bear Creek floodplain soils and sediments. ..................................3-39

3.16 Y-12 radiological characterization summary - Bear Creek Watershed...................................... 3-41 
3.17 Source areas, environmental infrastructure, and radiological contamination areas in the Bear Creek Watershed.

3-18 Source areas, environmental infrastructure, and radiological contamination areas in the Chestnut Ridge administrative area. 


\section{PLATES}

1 Waste management units and source area locations in the Bear Creek, Upper East Fork

Poplar Creek, and Chestnut Ridge areas. .

1A Waste management units and source area locations in the Upper East Fork Poplar Creek

Watershed. 3

1B Waste management units and source area locations in the Upper East Fork Poplar Creek

Watershed.

1C Waste management units and source area locations in the Upper East Fork Poplar Creek

Watershed.

2 Source areas, environmental infrastructure, and radiological contamination areas in the Upper East Fork Poplar Creek Watershed.

\section{ACRONYMS}

$\begin{array}{ll}\text { AEA } & \text { Atomic Energy Act } \\ \text { AHA } & \text { activity hazard analysis } \\ \text { AOC } & \text { area of contamination } \\ \text { BCBG } & \text { Bear Creek Burial Grounds } \\ \text { BCV } & \text { Bear Creek Valley } \\ \text { BMP } & \text { best management practice } \\ \text { BY/BY } & \text { Boneyard/Burnyard } \\ \text { C/D } & \text { construction/demolition } \\ \text { CAMU } & \text { Corrective Action Management Unit } \\ \text { CERCLA } & \text { Comprehensive Environmental Response, Compensation, and Liability Act } \\ \text { CFR } & \text { Code of Federal Regulations } \\ \text { CMTS } & \text { Central Mercury Treatment System } \\ \text { COC } & \text { constituent of concern } \\ \text { CWA } & \text { Clean Water Act } \\ \text { CX } & \text { Categorical Exclusion } \\ \text { DARA } & \text { Disposal Area Remedial Action } \\ \text { DOE } & \text { U. S. Department of Energy } \\ \text { EEVOC } & \text { East End Volatile Organic Compound } \\ \text { EM } & \text { Environmental Management } \\ \text { EMWMF } & \text { Environmental Management Waste Management Facility } \\ \text { EPA } & \text { U. S. Environmental Protection Agency } \\ \text { ES\&H } & \text { Environment, Safety, and Health (Division) } \\ \text { FCAP } & \text { Filled Coal Ash Pond } \\ \text { FFA } & \text { Federal Facilities Agreement } \\ \text { FFS } & \text { focused feasibility study } \\ \text { FR } & \text { Federal Register } \\ \text { FY } & \text { fiscal year } \\ \text { HSWA } & \text { RCRA Hazardous and Solid Waste Amendments of 1984 } \\ \text { IDW } & \text { investigation-derived waste } \\ \text { IH } & \text { industrial hygiene } \\ \text { KHQ } & \text { Kerr Hollow Quarry } \\ \text { LDR } & \text { land disposal restriction } \\ & \end{array}$




\section{PLATES}

1 Waste management units and source area locations in the Bear Creek, Upper East Fork

Poplar Creek, and Chestnut Ridge areas. .

1A Waste management units and source area locations in the Upper East Fork Poplar Creek

Watershed. 3

1B Waste management units and source area locations in the Upper East Fork Poplar Creek

Watershed.

1C Waste management units and source area locations in the Upper East Fork Poplar Creek

Watershed.

2 Source areas, environmental infrastructure, and radiological contamination areas in the Upper East Fork Poplar Creek Watershed.

\section{ACRONYMS}

$\begin{array}{ll}\text { AEA } & \text { Atomic Energy Act } \\ \text { AHA } & \text { activity hazard analysis } \\ \text { AOC } & \text { area of contamination } \\ \text { BCBG } & \text { Bear Creek Burial Grounds } \\ \text { BCV } & \text { Bear Creek Valley } \\ \text { BMP } & \text { best management practice } \\ \text { BY/BY } & \text { Boneyard/Burnyard } \\ \text { C/D } & \text { construction/demolition } \\ \text { CAMU } & \text { Corrective Action Management Unit } \\ \text { CERCLA } & \text { Comprehensive Environmental Response, Compensation, and Liability Act } \\ \text { CFR } & \text { Code of Federal Regulations } \\ \text { CMTS } & \text { Central Mercury Treatment System } \\ \text { COC } & \text { constituent of concern } \\ \text { CWA } & \text { Clean Water Act } \\ \text { CX } & \text { Categorical Exclusion } \\ \text { DARA } & \text { Disposal Area Remedial Action } \\ \text { DOE } & \text { U. S. Department of Energy } \\ \text { EEVOC } & \text { East End Volatile Organic Compound } \\ \text { EM } & \text { Environmental Management } \\ \text { EMWMF } & \text { Environmental Management Waste Management Facility } \\ \text { EPA } & \text { U. S. Environmental Protection Agency } \\ \text { ES\&H } & \text { Environment, Safety, and Health (Division) } \\ \text { FCAP } & \text { Filled Coal Ash Pond } \\ \text { FFA } & \text { Federal Facilities Agreement } \\ \text { FFS } & \text { focused feasibility study } \\ \text { FR } & \text { Federal Register } \\ \text { FY } & \text { fiscal year } \\ \text { HSWA } & \text { RCRA Hazardous and Solid Waste Amendments of 1984 } \\ \text { IDW } & \text { investigation-derived waste } \\ \text { IH } & \text { industrial hygiene } \\ \text { KHQ } & \text { Kerr Hollow Quarry } \\ \text { LDR } & \text { land disposal restriction } \\ & \end{array}$




$\begin{array}{ll}\text { LEFPC } & \text { Lower East Fork Poplar Creek } \\ \text { LUCIP } & \text { Land Use Control Implementation Plan } \\ \text { NCP } & \text { National Contingency Plan } \\ \text { NEPA } & \text { National Environmental Policy Act of 1969 } \\ \text { NFA } & \text { no further action } \\ \text { NFI } & \text { no further investigation } \\ \text { NNSA } & \text { National Nuclear Security Administration } \\ \text { NPDES } & \text { National Pollutant Discharge Elimination System } \\ \text { ORR } & \text { Oak Ridge Reservation } \\ \text { OSHA } & \text { Occupational Safety and Health Administration } \\ \text { PCB } & \text { polychlorinated biphenyl } \\ \text { PK } & \text { process knowledge } \\ \text { PPE } & \text { personal protection equipment } \\ \text { ppm } & \text { part per million } \\ \text { ppt } & \text { part per trillion } \\ \text { RA } & \text { remedial action } \\ \text { RADCON } & \text { radiological control } \\ \text { RAIMS } & \text { Remedial Action Information Management System } \\ \text { RCRA } & \text { Resource Conservation and Recovery Act } \\ \text { RER } & \text { Remediation Effectiveness Report } \\ \text { RI } & \text { remedial investigation } \\ \text { RMPE } & \text { Reduction of Mercury in Plant Effluent } \\ \text { ROD } & \text { record of decision } \\ \text { SVOC } & \text { semivolatile organic compound } \\ \text { SWDF } & \text { solid waste disposal facility } \\ \text { SWMU } & \text { solid waste management unit } \\ \text { TCLP } & \text { toxicity characteristic leaching procedure } \\ \text { TDEC } & \text { Tennessee Department of Environment and Conservation } \\ \text { TDRH } & \text { Tennessee Division of Radiological Health } \\ \text { TSCA } & \text { Toxic Substances Control Act } \\ \text { TSD } & \text { treatment, storage, and disposal } \\ \text { UEFPC } & \text { Upper East Fork Poplar Creek } \\ \text { UNC } & \text { United Nuclear Corporation } \\ \text { UST } & \text { underground storage tank } \\ \text { UTS } & \text { Universal Treatment Standard } \\ \text { VOC } & \text { volatile organic compound } \\ \text { WAC } & \text { waste acceptance criteria } \\ \text { WCPF } & \text { Waste Coolant Processing Facility } \\ \text { WEMA } & \text { West End Mercury Area } \\ \text { WRRP } & \text { Water Resources Restoration Program } \\ \text { Y-12 } & \text { Y-12 National Security Complex } \\ & \end{array}$




\section{EXECUTIVE SUMMARY}

This Soil Management Plan applies to all activities conducted under the auspices of the National Nuclear Security Administration (NNSA) Oak Ridge Y-12 National Security Complex (Y-12) that involve soil disturbance and potential management of waste soil. The plan was prepared under the direction of the Y-12 Environmental Compliance Department of the Environment, Safety, and Health Division. Soil disturbances related to maintenance activities, utility and building construction projects, or demolition projects fall within the purview of the plan. This Soil Management Plan represents an integrated, visually oriented, planning and information resource tool for decision making involving excavation or disturbance of soil at Y-12.

This Soil Management Plan addresses three primary elements.

1. Regulatory and programmatic requirements for management of soil based on the location of a soil disturbance project and/or the regulatory classification of any contaminants that may be present (Chap. 2). Five general regulatory or programmatic classifications of soil are recognized to be potentially present at $\mathrm{Y}-12$; soil may fall under one or more these classifications:

- Comprehensive Environmental Response, Compensation, and Liability Act (CERCLA) pursuant to the Oak Ridge Reservation (ORR) Federal Facilities Agreement;

- Resource Conservation and Recovery Act (RCRA);

- RCRA 3004(u) solid waste managements units pursuant to the RCRA Hazardous and Solid Waste Amendments Act of 1984 permit for the ORR;

- Toxic Substances and Control Act-regulated soil containing polychlorinated biphenyls; and

- Radiologically contaminated soil regulated under the Atomic Energy Act review process.

2. Information for project planners on current and future planned remedial actions (RAs), as prescribed by CERCLA decision documents (including the scope of the actions and remedial goals), land use controls implemented to support or maintain RAs, RCRA post-closure regulatory requirements for former waste management units, legacy contamination source areas and distribution of contamination in soils, and environmental infrastructure (e.g., caps, monitoring systems, etc.) that is in place or planned in association with RAs.

3. Regulatory considerations and processes for management and disposition of waste soil upon generation, including regulatory drivers, best management practices (BMPs), waste determination protocols, waste acceptance criteria, and existing waste management procedures and BMPs for Y-12.

This Soil Management Plan provides information to project planners to better coordinate their activities with other organizations and programs with a vested interest in soil disturbance activities at Y-12. The information allows project managers and maintenance personnel to evaluate and anticipate potential contaminant levels that may be present at a proposed soil disturbance site prior to commencement of activities and allows a more accurate assessment of potential waste management requirements. 
04-120(E)/030205 


\section{INTRODUCTION}

This Soil Management Plan applies to all activities conducted under the auspices of the National Nuclear Security Administration (NNSA) Oak Ridge Y-12 National Security Complex (Y-12) that involve soil disturbance and potential management of waste soil. This plan was prepared under the direction of the Y-12 Environmental Compliance Department of the Environment, Safety, and Health $($ ES\&H) Division. Planned soil disturbances related to maintenance activities, utility and building construction projects, or demolition projects fall within the purview of the plan. The plan may also serve as a useful reference for environmental projects conducted under the Comprehensive Environmental Response, Compensation, and Liability Act (CERCLA); however, such projects typically develop their own waste management specifications, including any special provisions for management of wastes within CERCLA areas of contamination (AOCs). This Soil Management Plan represents an integrated planning tool and information resource that encompasses land use controls; various potential regulatory controls; legacy contaminants and related remedial actions (RAs); environmental infrastructure; and waste soil management, characterization, and disposition.

\subsection{BACKGROUND AND PURPOSE}

Soil disturbance and excavation within Y-12 is frequently required as part of numerous activities, including routine maintenance projects and new utility or building construction. The need for a soil management plan has long been recognized and an initial version of a soil management plan was prepared in 1993 that focused almost exclusively on regulatory processes for management of excavated soils as wastes (Radian 1993). With maturation of the Oak Ridge Reservation (ORR) Environmental Management (EM) Program, along with Y-12 modernization plans and footprint reduction activities, the need for a more comprehensive plan is evident. A large collection of data has been compiled from historical and CERCLA characterization projects that is now available for use during planning for soil excavations. Additionally, numerous environmental response actions have been completed and future actions planned, which must be considered when planning for soil disturbance activities.

In consideration of the evolving complexity of programmatic interactions and regulatory requirements noted above, the objective of this revised Soil Management Plan is to serve as an information resource and decision-making tool for Y-12 project managers that achieves three objectives:

1. Provides regulatory and programmatic requirements for management of soil based on the location of a soil disturbance project and/or the regulatory classification of any contaminants that may be present (Chap. 2). Five general regulatory or programmatic classifications of soil are recognized to be potentially present at Y-12; soil may fall under one or more these classifications:

- CERCLA pursuant to the ORR Federal Facilities Agreement (FFA);

- Resource Conservation and Recovery Act (RCRA);

- $\quad$ RCRA 3004(u) solid waste managements units (SWMUs) pursuant to the RCRA Hazardous and Solid Waste Amendments Act of 1984 (HSWA) permit for ORR;

- Toxic Substances and Control Act (TSCA)-regulated soil containing polychlorinated biphenyls (PCBs); and

- Radiologically contaminated soil regulated under the Atomic Energy Act (AEA) review process. 
2. Presents information for project planners on current and future planned RAs, as prescribed by CERCLA decision documents (including the scope of the actions and remedial goals), land use controls implemented to support or maintain RAs, RCRA post-closure regulatory requirements for former waste management units, legacy contamination source areas and distribution of contamination in soils, and environmental infrastructure (e.g., caps, monitoring systems, etc.) that is in place or planned in association with RAs.

3. Presents regulatory considerations and processes for management and disposition of waste soil upon generation, including regulatory drivers, best management practices (BMPs), waste determination protocols, waste acceptance criteria (WAC), and existing waste management procedures and BMPs for Y-12.

Accordingly, this Soil Management Plan provides information for project planners to better coordinate their activities with other organizations and programs with a vested interest in soil disturbance activities at Y-12. The information will allow project managers and maintenance personnel to evaluate and anticipate potential contaminant levels that may be present at a proposed soil disturbance site prior to commencement of activities and will allow a more accurate assessment of potential waste management requirements.

\subsection{CONTENT AND USE OF THE PLAN}

This Soil Management Plan is designed and organized to be a user-friendly, visually oriented tool for decision making involving soil excavation or disturbance at Y-12. Where possible, interfaces and processes have been flowcharted for ease of use. Maps and plates illustrating locations of contaminant sources, completed and future RAs, and known occurrence and distribution of key legacy contaminants are provided wherever possible. This plan is not intended to present requirements, procedures, or historical information at a great level of detail; rather, summary information is provided to guide the user in the decision-making process with references to more definitive resources that may be accessed, as needed, for project planning purposes.

The regulatory and programmatic requirements section of this plan is provided to help the user define key considerations, information sources, and points of contact for identifying regulatory and procedural requirements that may apply to soil excavated from a site having a particular regulatory classification or containing certain types of regulated contaminants. Such considerations include identifying the location of the project, regulatory classification of soil contaminants known or determined to be present (e.g., RCRA, TSCA, radiological standards), and if a project site is located within areas governed under CERCLA decision documents, Land Use Control Implementation Plans (LUCIPs), or regulatory permits. Additionally, the Y-12 National Environmental Policy Act of 1969 (NEPA) checklist process and excavation/penetration permit process require multiple information inputs and decision points with respect to project planning.

A summary of legacy contamination in soil and baseline risks for industrial workers is provided to aid the user in assessing potential contaminants and concentrations that may be encountered within a planned soil disturbance area. The summary of legacy contamination is based on the most current compilations of data available, as presented in CERCLA Remedial Investigation (RI) Reports for the Upper East Fork Poplar Creek (UEFPC) and Bear Creek watersheds (DOE 1998, 1997). These documents incorporated available data from historical investigations and compliance programs, as well as new data collected expressly for the purposes of the RIs.

Information on completed environmental response actions taken to date, ongoing response actions, and planned future actions is also compiled. This information includes discussion of land use assumptions 
and remediation goals and, where applicable, the type of action taken and whether long-term performance monitoring is required under the terms of the decision. CERCLA decisions and other governing regulatory permits (e.g., RCRA post-closure permits) are summarized to inform the user of potential restrictions or limitations and land use assumptions that may affect planning decisions for soil disturbances. Identified former and current waste management areas, contaminant point sources, and other areas of known contamination (e.g., Bear Creek floodplain soil) are presented. As an example, soil excavation within a CERCLA AOC or source area may require characterization to determine whether contaminant levels exceed CERCLA remedial goals or other applicable standards, which may merit special considerations for further response actions or soil disposal. Additionally, RCRA post-closure regulations restrict the disturbance of engineered caps and monitoring systems installed as part of closure activities for former treatment, storage, and disposal (TSD) units.

Related to the summary of environmental response actions, a discussion of existing environmental infrastructure constructed as part of the responses is presented where possible (i.e., engineered caps, monitoring systems, and drainage control systems). As noted above, governing decision documents or permits frequently include restrictions or prohibitions for unapproved disturbance or damage to such systems, including the possibility of administrative violations and fines. This information points to the existence of such infrastructure and the awareness of this infrastructure may be incorporated into soil disturbance planning.

Lastly, this plan outlines the Y-12 processes for management and disposition of waste soil upon generation. This section includes a discussion of the flow of regulatory controls and the programmatic contacts/resources for project managers. Considerations for staging the excavated soil to meet site BMPs are provided for the plan user. Summary information is provided relative to characterization requirements; process knowledge (PK) determinations; and guidelines for selection of disposal options based on results of analyses, properties of the excavated material, and acceptance criteria of the disposal facilities. A brief overview of transportation requirements is also provided for soil characterized as low-level and hazardous waste, along with references to programmatic resources who can assist the project manager with identification of transportation requirements.

\subsection{CONFIGURATION MANAGEMENT}

This Soil Management Plan is maintained by the Y-12 ES\&H Division. This document is not subject to a controlled distribution and is not a controlled document. Routine periodic updates (e.g., annual or biannual) are not currently planned by the Y-12 ES\&H Division.

\subsection{ORGANIZATION}

The background, purpose, and content of this Soil Management Plan are presented in Chap. 1. Chapter 2 of this plan includes a discussion of programmatic and regulatory interfaces that may be required during the course of project planning or maintenance activities that involve soil disturbance. Chapter 3 represents a reference source for plan users containing a summary of legacy soil contamination; discussion of historical and future RAs that could affect planned soil disturbances; a summary of regulated units and areas; and a description of current environmental infrastructure that must be considered when planning soil disturbances. Chapter 4 of this plan outlines the regulatory and waste management processes required for managing soil once it is excavated. Appendix A contains the NEPA Review Project Checklist. A summary of identified regulated contaminant source units and non-specific AOCs (e.g., floodplain soils) is contained in Appendix B. Appendix C contains an example of the current Y-12 Excavation Permit. 
04-120(E)/030205 


\section{PROJECT PLANNING}

This chapter outlines project planning and preparatory processes that apply to most soil disturbance projects. These planning processes have been organized, and in some cases proceduralized, into project decision trees. The project decision trees are management tools that provide a consistent, rigorous framework for identifying regulatory or programmatic requirements that may apply to the project. The decision trees also provide indicators for relevant information inputs, critical path decision points, organizational points of contact, and project reporting requirements. The constant revision and change of regulations creates limitations to this and any other management planning tool and requires some level of generalization. Planning for anticipated rule changes is difficult; however, the basic framework for regulatory requirements pertaining to management of contaminated soil has been long established and is expected to remain relatively constant.

The placement of the entire ORR on the National Priorities List (NPL) and a large pool of historical characterization data indicates that all areas within Y-12 may be suspected of containing some level of contamination. Each soil-generating project is addressed independently; however, the basic project planning and preparatory process remains consistent from project to project. The first preference for management of soil within the Y-12 controlled area is staging of soil on the project site, following the Clean Water Act (CWA) BMPs, and placement back into the excavation upon completion (beneficial re-use). However, PK or visual inspections of the project site may indicate that further management of soil is required. Additionally, excess volume then can be beneficially re-used may be generated and require management as waste. Also, during project execution, indications of contamination (e.g., gross staining or strong odors) may be observed once soil excavation or movement begins, which may trigger duties to report and various other cleanup requirements [e.g., underground storage tank (UST) rules]. For soil not subject to beneficial re-use, the specific regulatory and programmatic requirements that apply must be identified in consultation with the Division Environmental Officer and Y-12 Waste Operations Organization personnel within the Y-12 ES\&H Division.

The basic screening process and the key branching programmatic or regulatory decision pathways are flowcharted in this chapter as a series of six decision trees for ease of reference. Text summaries describing the use of the decision trees are presented, along with discussions of key individual decision components for additional clarification. Each of the project decision trees relies, in some part, on information inputs summarized in Chap. 3. The end product of these project decision trees is a set of specific requirements that apply to management of soil generated by the project. Some of these requirements feed into the project waste management protocols, which include additional information inputs and decision points discussed in further detail in Chap. 4.

For completeness and to assist in ongoing efforts to address the nature and extent of contamination at Y-12, a clean soil decision tree was created in addition to those for various regulatory programs. Although no regulatory basis for this decision tree exists (because soil located outside an area that is subject to regulation does not require testing of any kind), prudence would suggest the establishment of some level of assessment. In the clean soil and other decision trees, reference is made to visual surveys and sampling and analysis for indicator parameters. This is a preliminary survey of the conditions associated with an area and is intended to indicate the presence or absence of contamination, not to fully characterize the area, such as would occur under a RCRA corrective action or CERCLA RA.

Where the decision trees refer to sampling and analysis to acquire more detailed knowledge of soil contamination, the intent is not to fully characterize the project site but to determine the presence or absence and concentrations of contamination. When no contamination is known or no prior sampling and

analysis has occurred, the presence or absence of contamination should be documented using a screening 
process consisting of two major steps. First, the location should be reconnoitered to collect information on potential sources of contamination, visibly contaminated soils, and other parameters based on professional judgment and considering the historical use of the area and its proximity to activities that might have impacted the location at some time. Second, soil samples should be collected and analyzed in a laboratory if the initial screening indicates the likely presence of contamination. The extent of sample collection shall be based on the size of the area, what the initial screening shows, and professional judgment. The analysis will provide additional information about the nature of the contamination or will deny that contamination is present. The Clean Area Decision Tree should be followed to completely evaluate these locations.

Generated investigation-derived waste (IDW) should be managed in the same manner as the soil from which it came would be managed. IDW that is generated within an AOC or SWMU, and is not removed from the boundaries of the area, may be returned to the place from which it was removed. IDW that has been removed to a laboratory setting, where it is shown to contain contamination, should be managed in compliance with applicable regulatory programs described in this Plan. IDW that remains at the generation area, but may not be returned to the ground, should be treated, stored, or disposed of in the same manner as is suggested for soil in this Plan. IDW with an undetermined status (i.e., analytical results are pending) should be managed in accordance with Y-12 policies and procedures.

\subsection{MASTER DECISION TREE}

The master decision tree (Fig. 2.1) is used to identify applicable programmatic and regulatory requirements for various situations and provides for selection of standardized, cost-effective, and compliant options for excavated soil management. Soil movement of any kind should be subjected to the decision tree analysis. Five distinct types of contaminated or potentially contaminated soil are expected to be present at Y-12, and decision trees for each type that branch from the master decision tree have been developed to relate the regulatory requirements and options. Proper utilization of the decision trees requires that the user first read the master decision tree and then read through all applicable regulatory program decision trees. Any construction engineering plans developed for use at the facility should consider whether soil will be disturbed as a result of the project execution.

\subsubsection{Project Identification and Location}

Upon project identification, a determination is made regarding the degree of review required under NEPA and Y-12 Comprehensive Environmental Review (Sect. 2.1.1.1). The NEPA/Comprehensive Environmental Review includes review of the project location and will determine if additional review is needed to determined if the project location is subject to regulatory programs or if additional screening is required (e.g., CERCLA screening). Field verification of current site conditions is recommended. The NEPA/Comprehensive Environmental Review produces a set of applicable environmental protection BMPs, inclusive of soil management.

Once it is determined that a candidate project will involve soil management, a CERCLA screening process (Sect. 2.1.1.2) is conducted to identify if the project location is within an area for which actions pursuant to CERCLA or RCRA post-closure have been conducted or are planned. If the project will not overlap areas subject to a regulatory program, the clean soil decision tree should be reviewed. If the project will involve soil management in an area subject to a regulatory program, an alternative location should be sought. If this is accomplished, the clean soil decision tree should be reviewed to identify management requirements for soil in areas where there is no suspected contamination. 


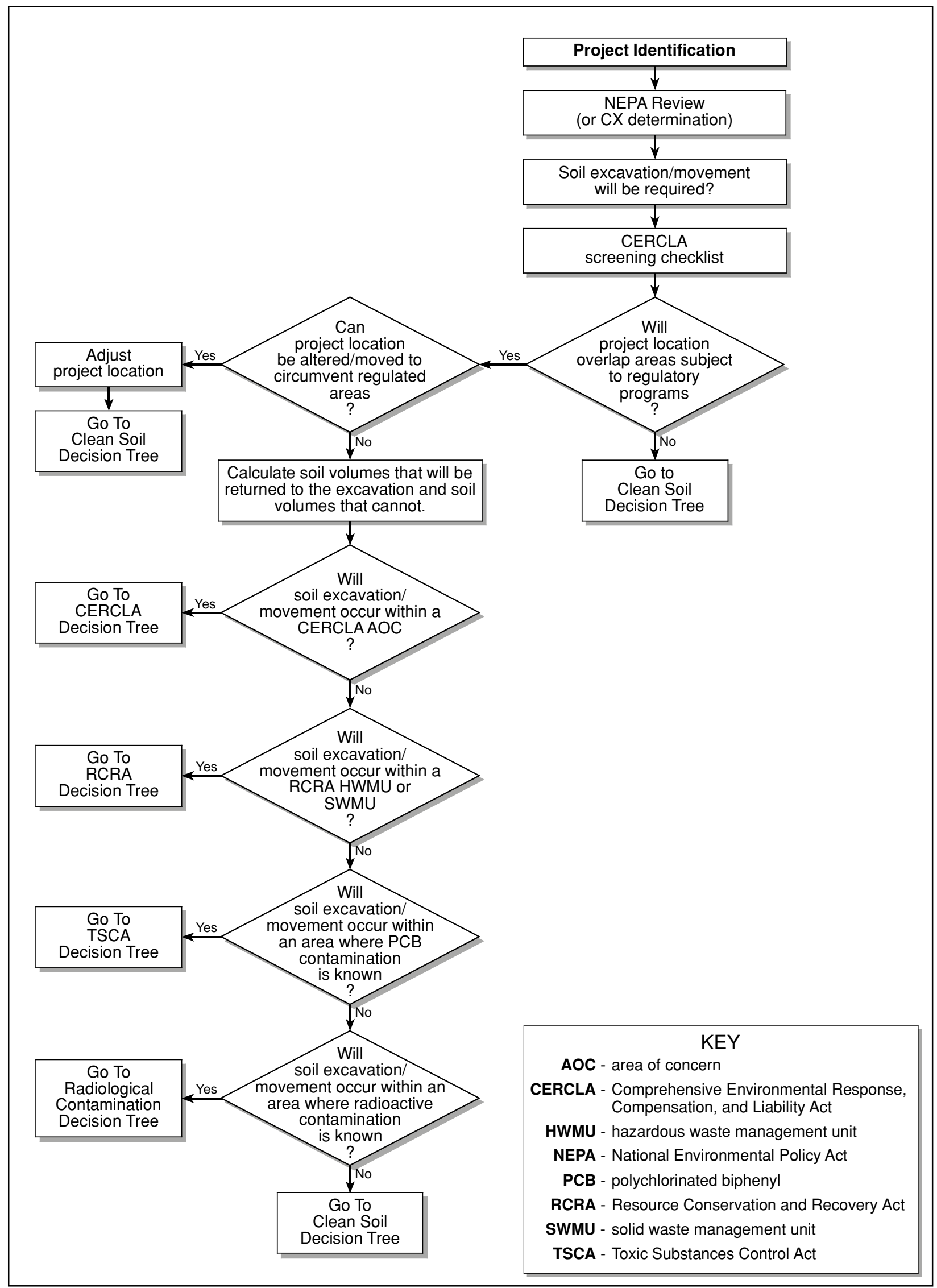

Fig. 2.1. Master decision tree.

G04-0128 flowchart 4 


\subsubsection{Y-12 NEPA/Comprehensive Environmental Review}

The NEPA/Comprehensive Environmental Review process is conducted by the Y-12 ES\&H Division and has been proceduralized in the form of a NEPA checklist (Appendix A). Some types of routine maintenance and environmental compliance activities have been categorically reviewed and are covered under a Categorical Exclusion (CX; CX-GEN-011); thus, specific projects may be exempted from the full NEPA review should they fall under the purview of the CX. However, the CX includes provisions for individual project NEPA review should the action have the potential to result in an unusual or minor impact to the environment.

The NEPA review process is a broad-based review of

- applicable environmental regulations,

- $\quad$ potential environmental impacts of a proposed activity,

- $\quad$ potential impacts on facility infrastructure and utilities,

- potential disturbances of hazardous or radiologically contaminated materials (e.g., soil, groundwater, etc.),

- $\quad$ waste generation and handling, and

- $\quad$ potential waste minimization BMPs that may be applied.

In terms of direct applicability to soil disturbances, the NEPA review forces an examination of the regulatory implications of a planned activity, an examination of the presence of legacy contamination and source areas within the project footprint, and initiates the proper oversight and interfaces required for management and disposition of any contaminated soil that may be generated. Optimally, the NEPA review is conducted simultaneously with the CERCLA screening process because both processes rely on several of the same information inputs, which are supported by Chap. 3 of this Plan (e.g., locations of remedial response actions, legacy contaminants, source areas, and environmental infrastructure).

The end product of the NEPA review is a set of applicable environmental protection BMPs and requirements for project implementation, including soil management. The NEPA review product helps to identify regulatory requirements that could potentially apply to soil that is not be eligible for beneficial re-use (e.g., returned to the excavation). The review further denotes whether new permits, modified permits, or other notifications to regulatory agencies may be required prior to soil disturbance activities (e.g., stormwater permits, RCRA post-closure permit notifications, etc.). The review product also provides indicators as to the need for excavation/penetration permits and industrial hygiene (IH) review or support on the project.

\subsubsection{Y-12 CERCLA screening process}

The CERCLA screening process focuses on:

- legacy contaminants that may be present in soil and associated remediation goals,

- $\quad$ project impacts on planned future RAs under CERCLA, 
- $\quad$ project relationship and potential impacts with respect to the land use basis for current and planned future CERCLA decisions, and

- $\quad$ potential project impacts on contaminant migration patterns (i.e., groundwater and surface water).

Although not specifically a soil management issue, the screening process also addresses demolition of contaminated buildings with respect to assessing the potential for releases of contaminants to the environment. If such facility demolition activities may require excavation and management of adjacent soil that becomes contaminated, then the requirements of this Soil Management Plan are applicable.

Figure 2.2 illustrates the overall Y-12 CERCLA screening process for soil disturbance activities. Table 2.1 lists the information inputs into the initial decision point as to whether or not CERCLA oversight may be required. Summary data for most of these information inputs are presented in Chap. 3, including overviews of legacy contamination, current and future planned RAs, and the land use basis. If a decision is reached wherein the project may require additional CERCLA oversight, a written project summary is compiled for more detailed evaluation by NNSA and FFA project managers as to whether CERCLA oversight is required. Upon reaching an affirmative decision point regarding CERCLA oversight, specific requirements and documentation needs with respect to FFA and reporting mechanisms for communicating with FFA managers are established. The decision pathway for soil management within a CERCLA AOC is further discussed below. For negative decisions with respect to CERCLA oversight, the project may be subject to other requirements of other environmental regulations.

\subsubsection{Soil Management in Areas Subject to Regulatory Programs}

Through review of the information inputs (e.g., maps, data, permits, decision documents, etc.) for the NEPA/Comprehensive Environmental Review and the CERCLA screening, a determination is made that the project will overlap areas subject to regulatory programs. Where this is the case, the master decision tree pathway is followed through to the appropriate programmatic or regulatory-specific decision trees for additional planning considerations before continuing with the planned project. Each of the specific decision trees is described in further detail in Sects. 2.2 through 2.6.

In many cases where soil will be subject to regulatory programs, the option of soil replacement or beneficial re-use (returned to the excavation) will be available. In cases where the entire volume of soil to be excavated cannot be accommodated in a beneficial re-use scenario, the calculated volume of soil not to be returned to its original location will be subject to different management scenarios under different regulatory programs. BMPs and other applicable requirements of CWA regulations will be specified as part of the NEPA/Comprehensive Environmental Review to ensure the control of erosion or runoff due to contaminant migration. Additional information on BMPs and limitations on beneficial re-use is provided in Chap. 4.

\subsubsection{Other Program and Regulatory Requirements Impacting Soil Excavation and Movement}

Other regulatory programs, although outside of the specific scope of this Plan, may also pertain to a soil disturbance project and are included for completeness.

\section{Classified Materials}

Special requirements for the management of classified materials may apply in addition to 


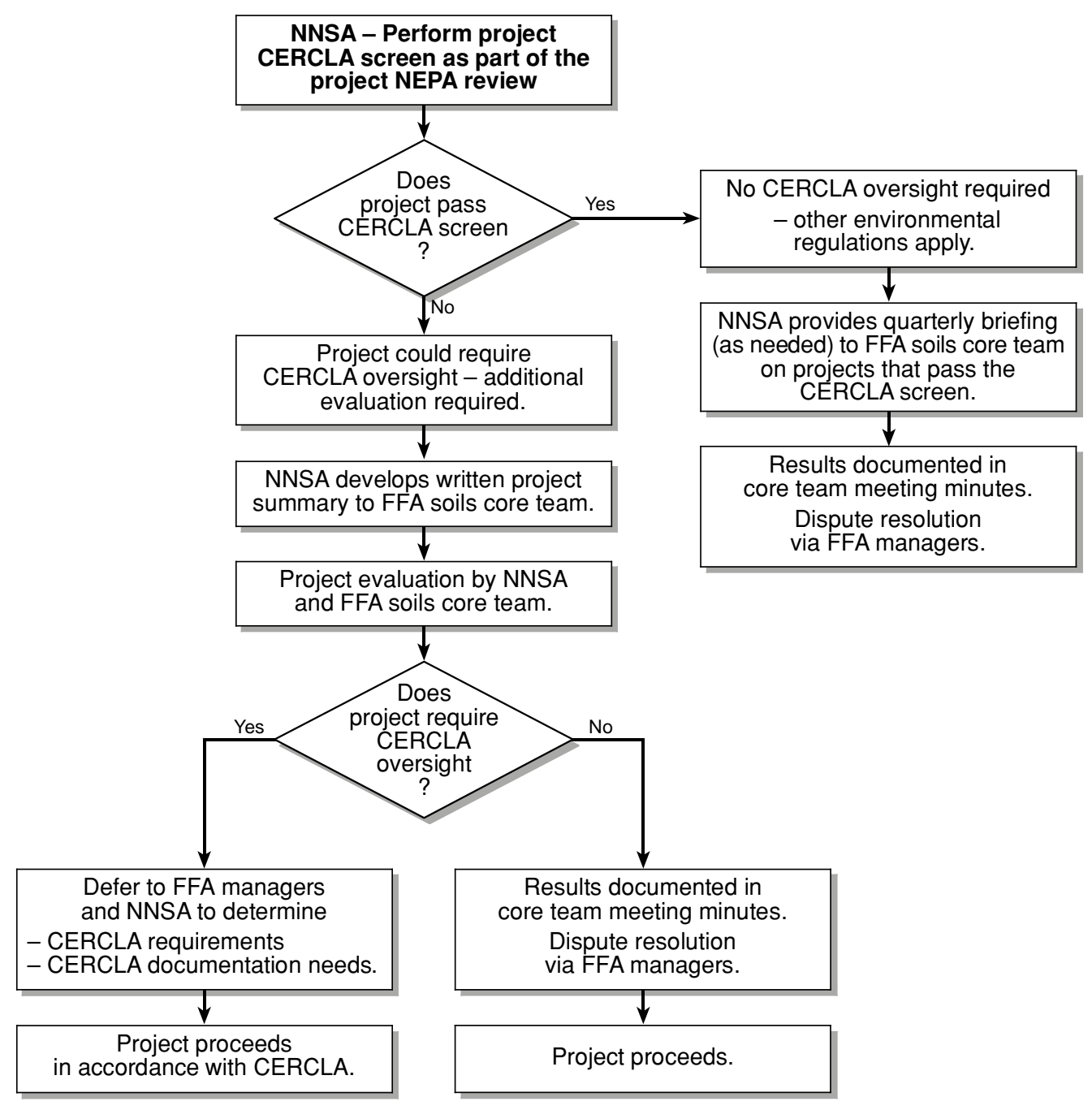

\section{KEY}

CERCLA - Comprehensive Environmental Response, Compensation, and Liability Act

FFA - Federal Facilities Agreement

NEPA - National Environmental Policy Act

NNSA - National Nuclear Security Agency

Fig. 2.2. Y-12 National Security Complex soil disturbance project CERCLA screening process. 
Table 2.1. Y-12 National Security Complex soil disturbance project CERCLA Screening Checklist

1. Impact on Future Planned Remedial Action: Evaluation whether the proposed project will interfere with existing or planned environmental remediation actions at the Y-12 National Security Complex other than soil (which is addressed in checklist item number 2, below).

Are any Federal Facilities Agreement Appendix C-listed remediation sites/facilities within the boundary of the proposed project footprint (excluding soil contamination areas, which is addressed in item 2, below)?

Will the proposed project adversely impair planned groundwater remediation activities?

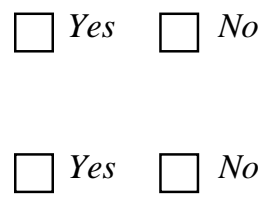

2. Soil Contamination Evaluation: Evaluation whether the proposed project will disturb areas where soil contaminants are above soil remediation criteria as defined in the Upper East Fork Poplar Creek (UEFPC) Soil and Scrapyard Focused Facility Study.

Does the proposed project footprint encompass any identified soil contamination "hotspot," $\square$ Yes $\square$ No as identified in the UEFPC Soils and Scrapyard Focused Feasibility Study?

Note: Any project-specific soil sampling results that show soil contamination above levels established in the UEFPC Soil and Scrapyard Focused Feasibility Study will require further consultation with regulatory agencies to identify CERCLA requirements.

3. Changes to Planned Future Land Use: Evaluation whether the proposed project will change the planned future land use of the site from continued long-term industrial use by the federal government for defense-related purposes.

Will the proposed project involve change of existing land use by the U. S. Federal $\square$ Yes $\square$ No Government for industrial defense-related purposes?

4. Impact on Contaminant Migration: Evaluation whether the proposed project will potentially change contaminant migration due to changes in surface water or groundwater flow.

Will the proposed project alter surface water or groundwater flow within the Y-12 National Security Complex such that the potential exists to adversely impact migration of legacy contamination?

5. Building Demolition Only-Site Characterization Evaluation: Evaluation whether the proposed building demolition will demolish facilities that are process contaminated with hazardous and/or radioactive materials such that a potential threat of a release to the environment exists if the demolition is not accomplished with proper engineering controls.

Has the facility to be demolished been known to process hazardous or radioactive materials in uncontained equipment and/or containers (i.e., excluding material storage in closed containers/tanks, process operations in glove boxes, or other contained equipment, etc.)?

Has the facility to be demolished been a hazard category I, II, or III Nuclear Facility or a Chemically Hazardous Facility, as defined by the Y-12 Facility Safety Program Description?

Has the operation of the facility included any history of hazardous substance $\square$ Yes $\square$ No spills/releases?

Note: Any project-specific site characterization sampling results that show widespread contamination of hazardous or radioactive materials throughout the facility will require further review to determine if existing process knowledge information on historical use is accurate.

Note: Answering "Yes" to any of the CERCLA screening questions will require further consultation with regulatory agencies to identify CERCLA requirements and establish CERCLA documentation requirements. 
requirements provided in the program-specific decision trees. Prior to project work in areas that potentially contain classified material, interfaces with the appropriate Y-12 classification and security organizations must be initiated and relevant requirements incorporated into soil management planning.

\section{OSHA or RADCON Requirements}

Occupational Safety and Health Administration (OSHA) and/or Radiological Control (RADCON) requirements may dictate the use of personal protection equipment (PPE) and/or engineered controls during soil disturbance. For example, soil movement within a regulated area [e.g., an operable unit (OU)] must be carried out by workers trained in accordance with the OSHA Hazard Waste Operations and Emergency Response Standard [29 Code of Federal Regulations (CFR) 1910.120(e)]. Such requirements are dictated through Y-12 Health and Safety Procedures Y73-378, Safe Conduct of Excavation/Penetration Work, and Y73-164, Subcontractor Environmental Safety and Health Management, which mandate health and safety organizational evaluation of planned activities involving excavation or disturbance of soil, as well as other types of work activities. The mechanism for this organizational evaluation is the Activity Hazard Analysis (AHA). The AHA serves to document potential physical, chemical, and radiological hazards that may be encountered during the course of work. The AHA also identifies the appropriate engineering and administrative controls and monitoring activities (environmental and personnel monitoring) that are to be implemented to mitigate those hazards.

\section{Excavation Permit Process}

The excavation permit review process is mandatory for all planned soil disturbances at Y-12. Excavations that may penetrate $1 \mathrm{ft}$ or deeper below ground surface require an excavation permit. The process also triggers notification to the RADCON organization (regardless of whether an excavation permit is required) prior to the start of work. The process is initiated through the Engineering Organization and documented in accordance with Y-12 Engineering Procedure Y17-69-410, Initiation, Review, and Termination of Excavation/Penetration Permits. Responsibility for initiating and obtaining a completed excavation permit (Appendix C) prior to the start of work lies with the project manager or designee. The excavation permit review focuses on the presence of physical plant infrastructure, which, if disturbed, could have negative safety or environmental consequences or impact facility operations or security. This Soil Management Plan does not attempt to provide the requisite information for completing excavation permits. The excavation permit review does not specifically encompass environmental remediation infrastructure (e.g., monitoring systems, engineered caps, drainage controls, etc.). Provisions for these types of infrastructure are included as part of the CERCLA process review and, in part, the NEPA checklist review. Summary information on environmental remediation infrastructure is contained in Sects. 3.1 and 3.4, respectively.

\subsection{USING THE COMPREHENSIVE ENVIRONMENTAL RESPONSE, COMPENSATION, AND LIABILITY ACT DECISION TREE}

Projects involving soil management will be impacted by CERCLA if they fall into a designated regulatory area such as an AOC or an OU for which a remedial decision has been completed, is ongoing, or is planned. This determination is made through the CERCLA project screening process. Although the large majority of investigative activities under CERCLA within the Y-12 area of responsibility have been completed, portions of AOCs that may be slated for further characterization also must be considered. Because of the broad definitions of AOCs and OUs, many areas within Y-12 are potentially subject to the rules associated with operations within a CERCLA AOC even though the project may not be located within a specific source area (e.g., UEFPC soil and scrapyard, Sect. 3.1.2). The specific decision tree addressing soil management within a CERCLA AOC is provided in Fig. 2.3. 


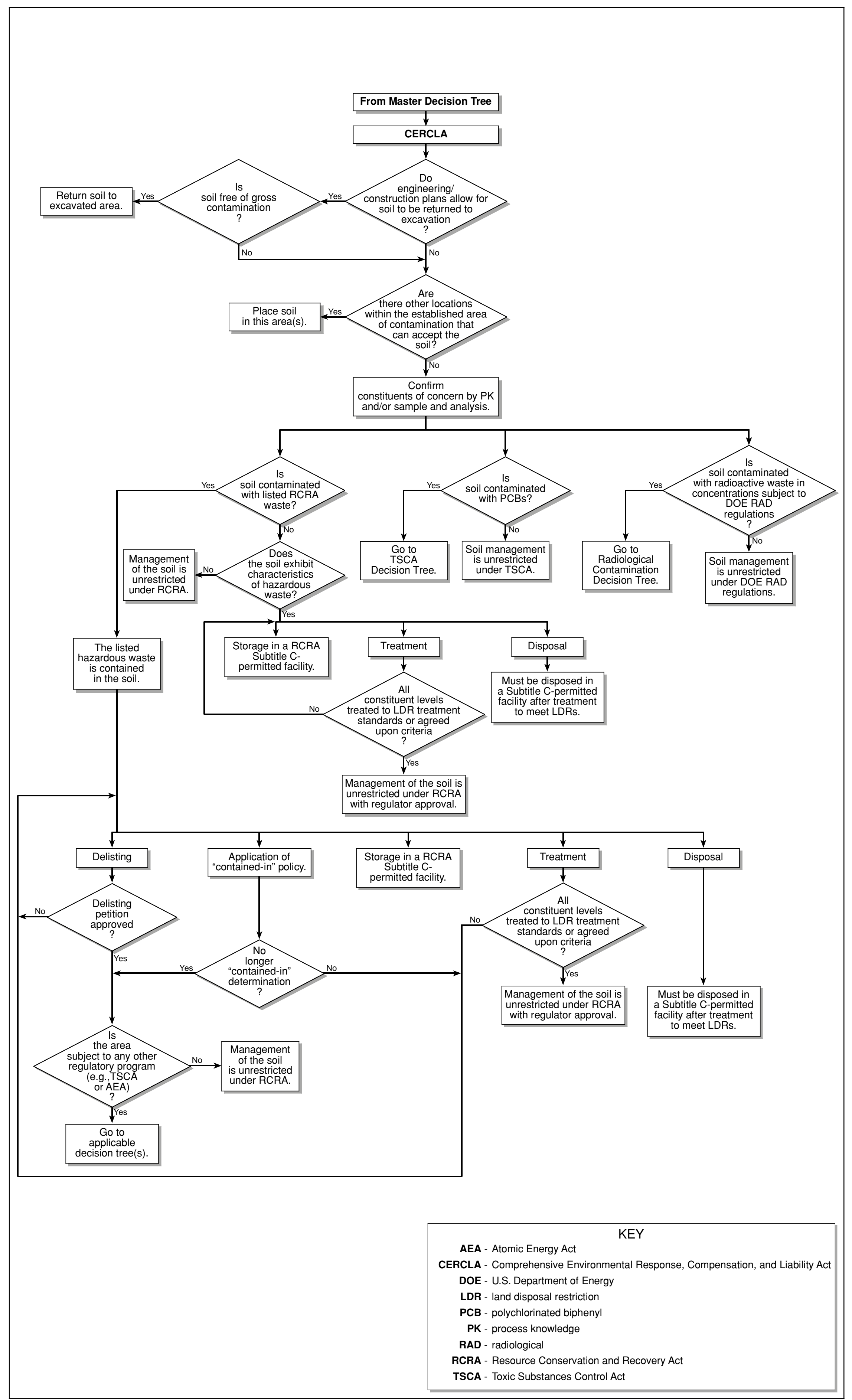

Fig. 2.3. Decision tree for compliance with CERCLA. 


\subsubsection{Soil Disposition}

Specific project construction and engineering plans shall be reviewed to assess the soil volumes to be excavated, the required depths of the excavations, and the total displacement that will occur because of the project.

\subsubsection{Beneficial re-use}

Soil excavated as part of an RA within a CERCLA AOC may be returned to its excavation point, and the return of the soil is not considered to be placement when moving soil within a unit [55 Federal Register (FR) 8758]. The concept of placement triggers other regulatory controls, namely RCRA land disposal restriction (LDR) requirements. The U. S. Environmental Protection Agency (EPA) interprets placement to mean putting hazardous wastes into one of these units, not the movement of waste within the unit (55 FR 8759, 51 FR 40577, and 54 FR 41566). In 2002, EPA promulgated the Corrective Action Management Unit (CAMU) Rule through which beneficial re-use or soil replacement may be extended to multiple AOCs subject to requesting and obtaining a CAMU determination. The preamble to the NCP further clarifies that normal earthmoving and grading operations within a unit would not be considered placement and thus would not trigger LDRs (55 FR 8759-60). Soil excavated within a CERCLA AOC during a project that is not part of an RA (e.g., maintenance, construction) may not be subject to the conditions above and regulatory determination should be made as part of project planning.

\subsubsection{Soil replacement within the designated unit}

Soil that has been excavated during an RA from within a CERCLA AOC and that cannot be beneficially re-used due to engineering constraints may be placed in other areas within the same AOC (53 FR 51444-5). If the soil volume is greater than can be accommodated in an AOC, the excess soil must

be managed as a contaminated soil and is subject to established regulatory controls. Soil that is not to be returned to the unit should undergo sampling and analysis either to confirm the constituents of concern (COCs) or to make a hazardous waste determination and identify treatment requirements for LDRs. As noted for beneficial re-use, a regulatory determination should be made for other types of projects within an AOC.

\subsubsection{Soil That Cannot be Managed Within the Unit}

For soil that cannot be returned to the excavation site or remain within the boundary of the AOC, other management is required. Once confirmatory sampling and analysis are performed, applicable regulatory programs must be identified and followed.

\subsubsection{Soil contaminated with RCRA hazardous waste}

When doubt exists regarding the RCRA status of a waste, conservative assumptions should be made in favor of RCRA jurisdiction. Sources of COCs should be identified, but if this information is not available, the soil should be assessed for likely contamination (e.g., PK determination) and for hazardous waste characteristics [defined at TN Rule 1200-1-11.02(3)]. If the soil is determined to be contaminated with listed constituents, and if the process that released listed hazardous waste can be identified and linked to the contamination present in the soil, the listing must apply. Before attempting to manage soil contaminated with RCRA hazardous waste, the RCRA decision tree and waste management requirements of Chap. 4 should be reviewed. 


\subsubsection{Soil contaminated with PCBs}

When sampling and analysis results show PCBs, the contamination source must be identified. TSCA regulatory requirements for PCBs vary depending on the date of the spill, the concentration of the PCB material contaminating the soil, and the accessibility of the contamination. Before attempting to manage soil contaminated with PCBs, the PCB decision tree should be reviewed.

\subsubsection{Soil that contains low-level radioactive material}

When sampling and analysis results show levels of radioactivity above designated background levels, certain steps must be taken. Before attempting to manage soil considered or suspected of being low-level radioactive waste or low-level mixed radioactive waste, the low-level radioactive waste decision tree should be reviewed.

\subsection{USING THE RESOURCE CONSERVATION AND RECOVERY ACT DECISION TREE}

Figure 2.4 illustrates the decision tree for managing soil under RCRA regulatory drivers. If the soil disturbance project falls into any of the following regulatory areas, RCRA requirements potentially apply:

- Hazardous waste management unit (HWMU) (TN Rule 1200-1-11);

- $\quad$ SWMU (50 FR 28712, 55 FR 30808);

- Area of suspected contamination, listed waste; and

- Area of suspected contamination, characteristic waste.

Under Subtitle C of RCRA, hazardous wastes, as defined in TN Rule 1200-1-11.02(1)(c), are waste streams that are either listed in TN Rule 1200-1-11.02(4) or exhibit a characteristic of hazardous waste described in TN Rule 1200-1-11.02(3). Appendix 02/E to TN Rule 1200-1-11 lists hazardous constituents, sometimes called COCs, which are associated with the hazardous waste listings. Presence of Appendix 02/E constituents in a waste does not automatically designate that waste as a RCRA hazardous waste, i.e., listed or characteristic. Solid wastes that are not listed as hazardous wastes and do not exhibit a characteristic of hazardous waste may contain hazardous constituents. The uncontrolled release of hazardous constituents from SWMUs, via solid waste, is subject to corrective action under RCRA Sect. 3004(u).

\subsubsection{Soil Movement Within a Hazardous Waste Management Unit}

A HWMU is defined as a contiguous area on or in which hazardous waste is placed, or the largest area on or in which there is significant likelihood of mixing hazardous waste constituents in the same area. Examples of HWMUs include hazardous waste incinerators, surface impoundments, or tanks and associated piping. HWMUs are subject to RCRA permitting requirements. Active permitted HWMUs at Y-12 are precluded from any soil disturbance other than that required for unit construction or maintenance needs. Seven former HWMUs at Y-12 (see Sect. 3.1) are closed and in post-closure status; soil disturbance within these areas is prohibited without prior approval of the Tennessee Department of Environment and Conservation (TDEC). Under the terms of the RCRA post-closure permits for the seven former HWMUs, any required corrective actions are deferred to the CERCLA process. Various historical characterization data are available for the closed HWMUs within Y-12; these data have been incorporated into the CERCLA process, along with newer characterization data and are available for determining disposition requirements for any soil that may require excavation within the units. 
04-120(E)/030205 


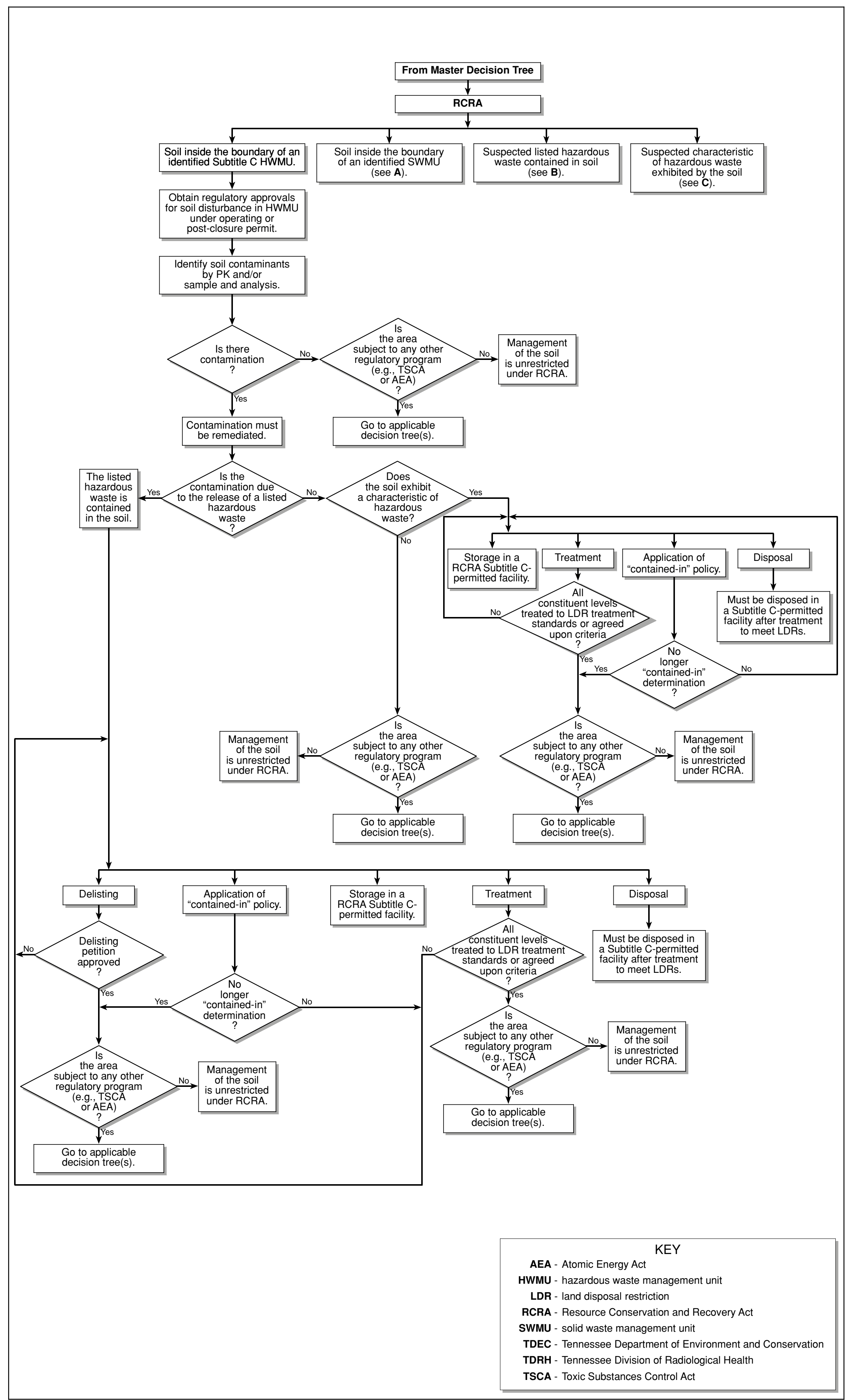




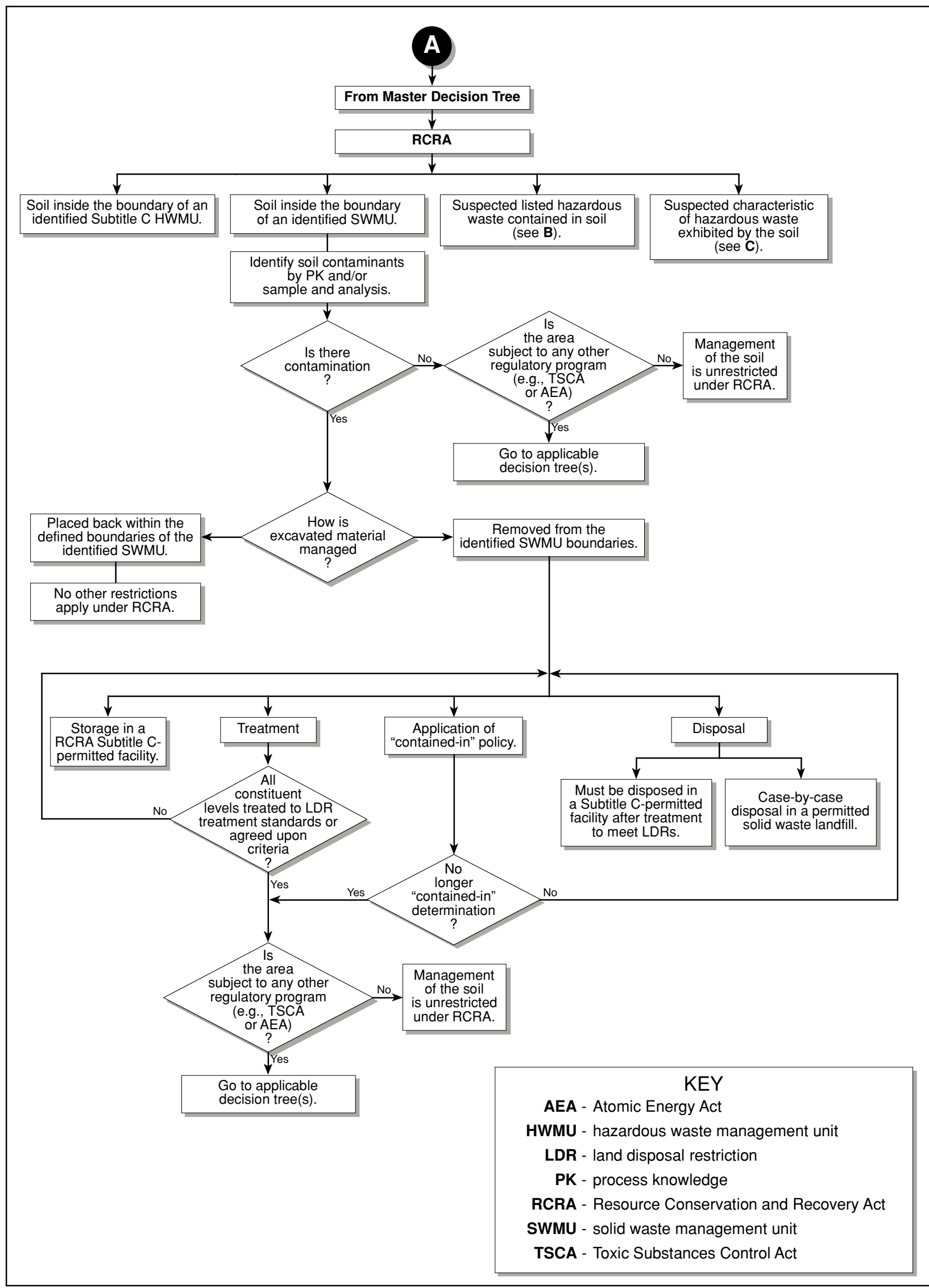

Fig. 2.4. (continued)

G04-0128 flowchart 7 B 


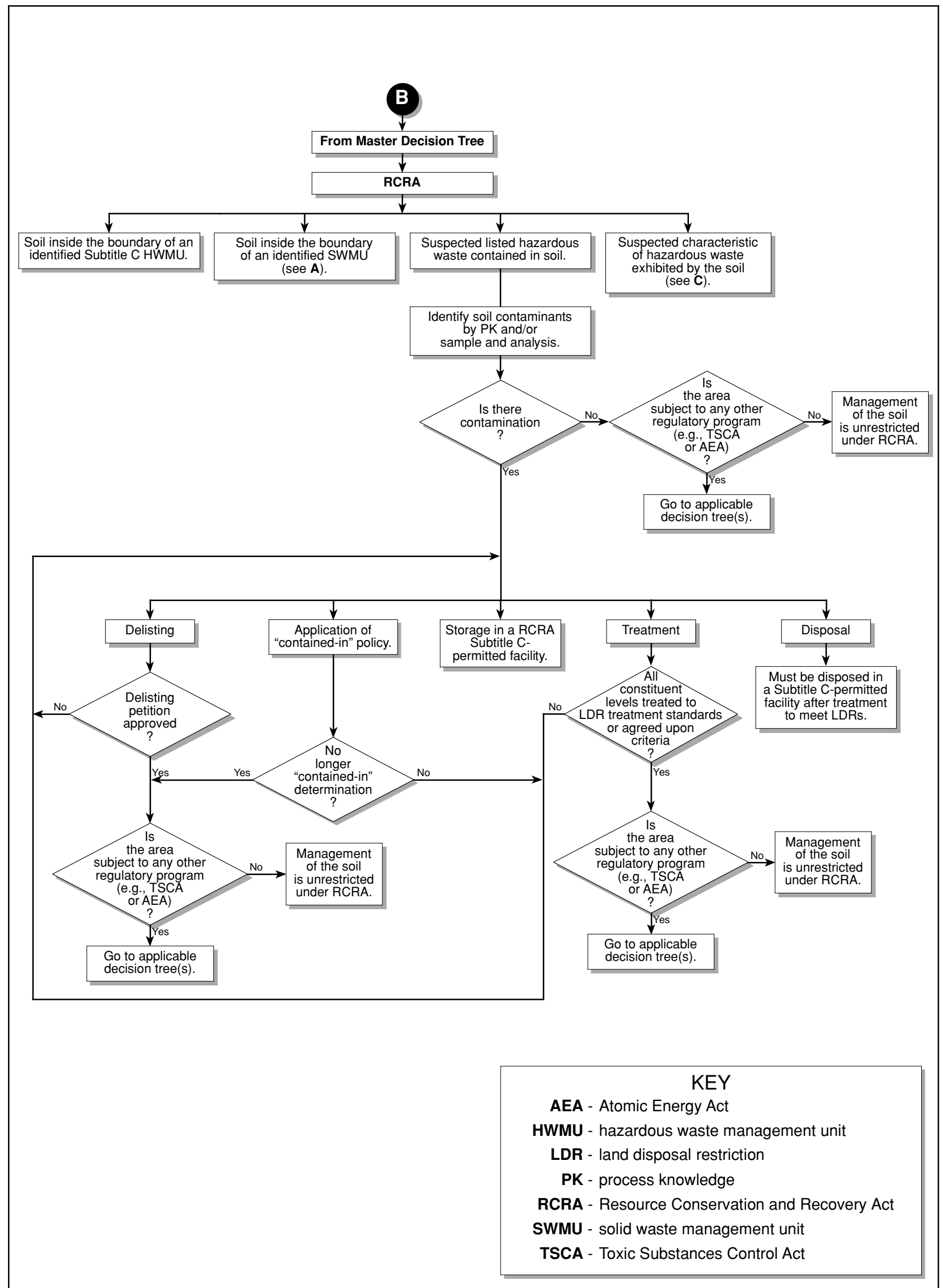

Fig. 2.4. (continued)

G04-0128 flowchart 8 B 


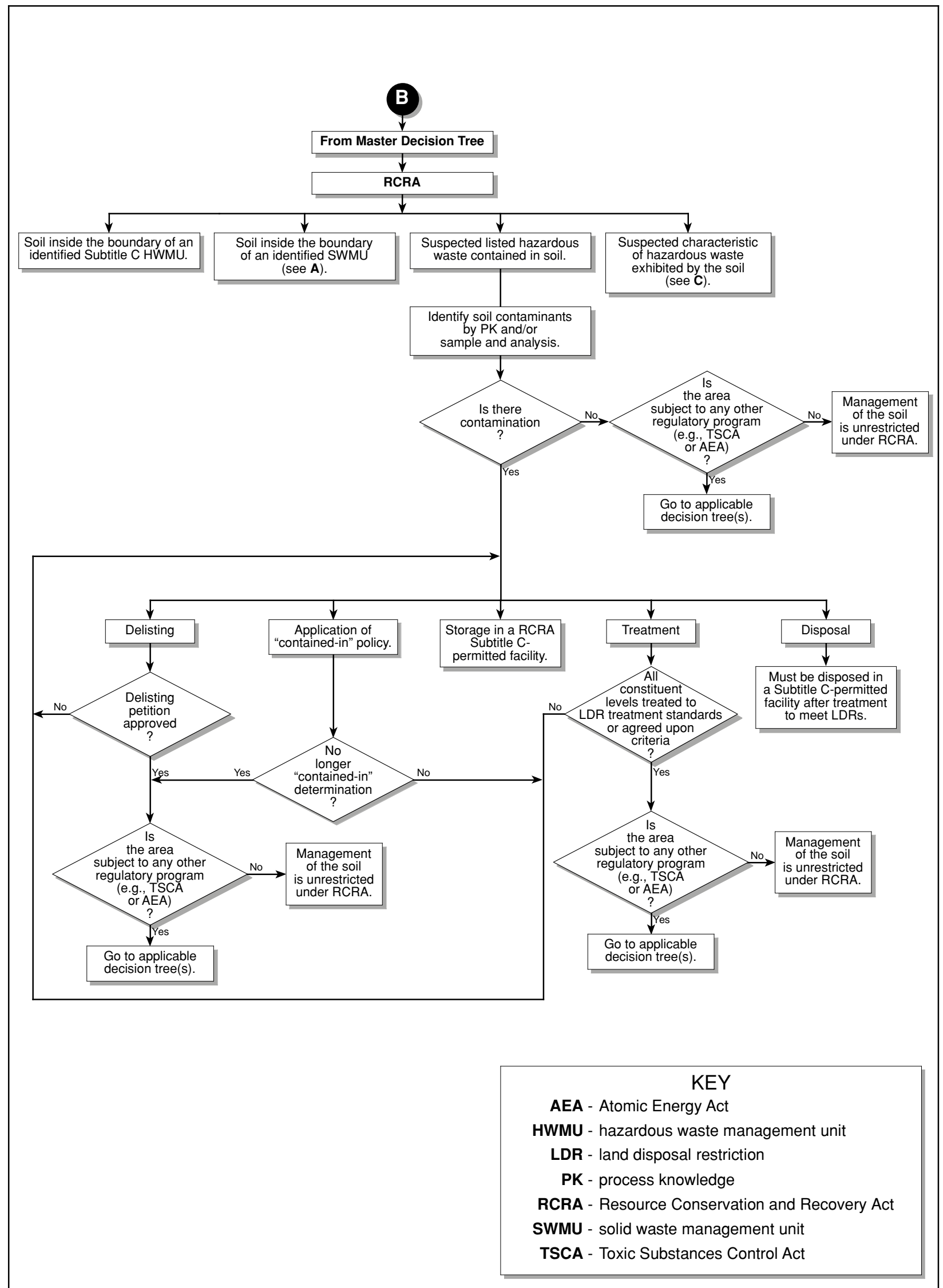

Fig. 2.4. (continued)

G04-0128 flowchart 8 B 


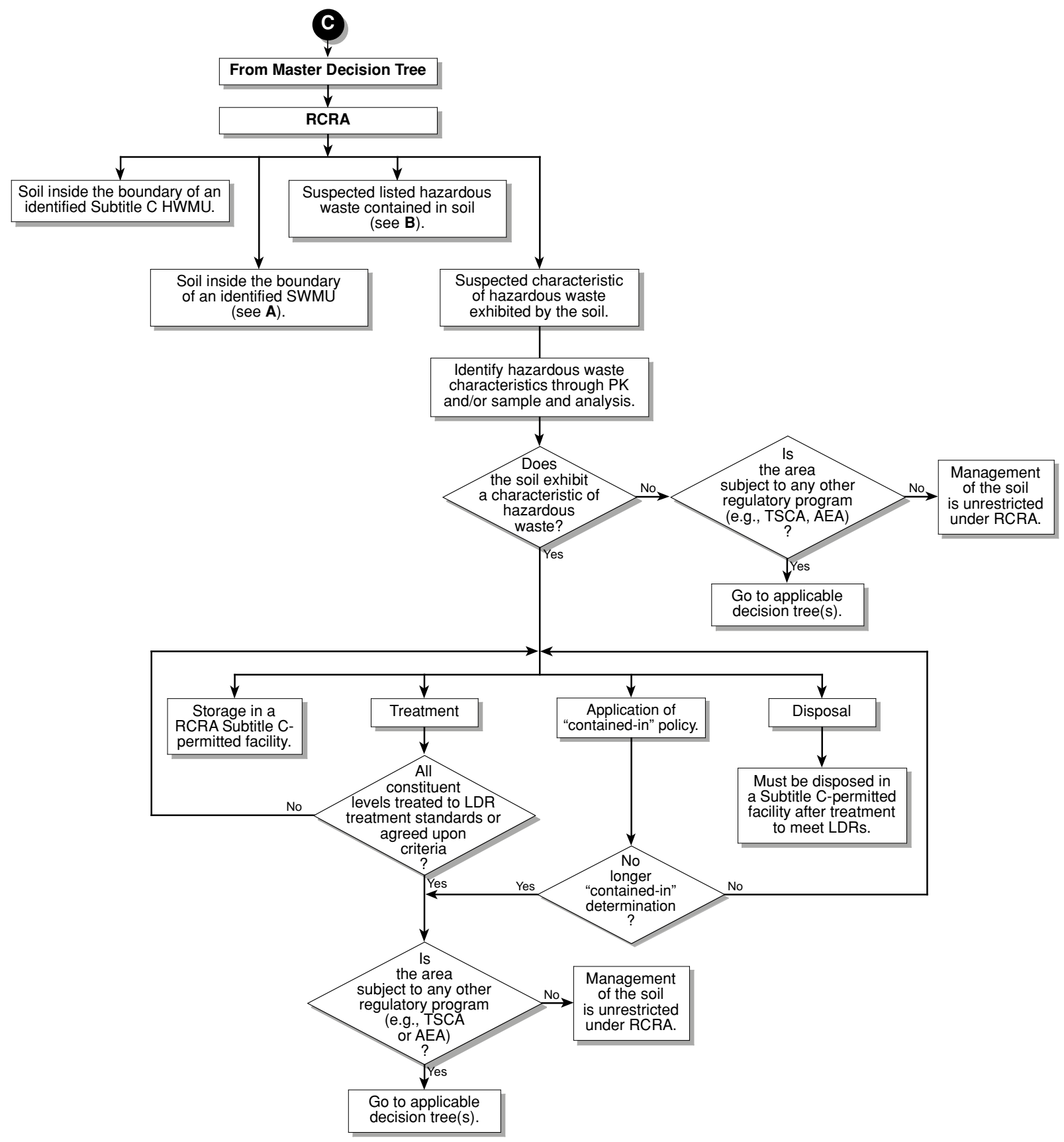

\begin{tabular}{|c|} 
KEY \\
AEA - Atomic Energy Act \\
HWMU - hazardous waste management unit \\
LDR - land disposal restriction \\
PK - process knowledge \\
RCRA - Resource Conservation and Recovery Act \\
SWMU - solid waste management unit \\
TSCA - Toxic Substances Control Act \\
\hline
\end{tabular}

Fig. 2.4. (continued)

G04-0128 flowchart 9 B 
Should soil disturbance within a HWMU be required, a PK determination is initially made on the basis of available data. Where insufficient data exist, soil samples should be collected and analyzed for constituents based on known or suspected characteristics of wastes disposed, stored, or treated at the unit.

If the soil analyses show the presence of listed or characteristic hazardous waste, management of the soil under the RCRA decision tree is required. Contamination due to a listed hazardous waste would require the use of some combination of the following management options (see Chap. 4):

- Delisting;

- Application of the Contained-in Policy (no longer "contained in" determination, regulatory approval that listed constituents are less than agreed upon criteria);

- Storage;

- Treatment to agreed upon criteria for hazardous constituents specified by appropriate regulatory authorities for beneficial re-use; and

- Treatment to below LDRs with disposal (Subtitle C hazardous waste management facility or case-bycase disposal in a permitted solid waste facility).

Soil analyses that show the presence of one or more hazardous waste characteristics in the soil would also require the use of some combination of storage, no longer "contained-in" determination, treatment, and disposal. If a listed hazardous waste or hazardous waste characteristic is not associated with the soil, management of the soil is unrestricted under RCRA (e.g., eligible for beneficial re-use).

\subsubsection{Soil Management Within a Solid Waste Management Unit}

A SWMU has been identified as "Any discernable unit at which wastes have been placed at any time, irrespective of whether the unit was intended for the management of solid or hazardous waste." Such units may include any area at a facility at which solid wastes have been routinely and systematically placed (55 FR 30808). Examples of SWMUs include tanks, container storage areas, recycling units, and loading and unloading areas. The HSWA corrective action permit for the ORR identifies SWMUs within Y-12; this information is summarized in Sect. 3.2 and Appendix B. The HSWA permit defers corrective action requirements for SWMUs to the CERCLA process. Historical characterization data are available for a number of SWMUs within Y-12; these data have been incorporated into the CERCLA process, along with newer characterization data and are available for determining disposition requirements for soil excavated within SWMUs (see Sect. 3.3).

If the soil disturbance project is to be conducted within an area identified as a SWMU, a PK determination is initially made on the basis of available data. If RCRA facility investigation (RFI) or CERCLA RI data are nonexistent or insufficient and specific hazardous COCs are not identified, soil samples should be collected and analyses performed for known or suspected site-related hazardous constituents based on operational history.

Should analyses indicate that the soil contains listed hazardous waste or the presence of one or more hazardous waste characteristics, certain restrictions will apply to the task of excavating or moving the soil. Excavated soil that remains within the designated boundaries of the SWMU may be replaced in the 
excavation or elsewhere within the SWMU. Soil removed outside the SWMU boundaries, however, would require some combination of storage, treatment, or disposal options as follows:

- $\quad$ Storage;

- $\quad$ Application of the Contained-in Policy;

- Treatment to below LDR treatment standards for hazardous constituents specified by appropriate regulatory authorities or continued management; and

- Disposal, in a Subtitle C hazardous waste management facility or case-by-case disposal in a permitted solid waste facility.

If no listed wastes or characteristically hazardous contamination is identified in the excavated soil, the management of the soil is unrestricted under RCRA. Likewise, if the soil is placed back within the boundaries of the identified SWMU, the soil is not subject to management restrictions until the SWMU is remediated.

\subsubsection{Area of Suspected Contamination, Listed Hazardous Waste}

If a release within an area is suspected where soil will be excavated, soil samples should be collected and an analysis performed for constituents associated with the suspected release.

If soil analyses show contamination, appropriate soil management is required. Contamination due to the presence of listed hazardous wastes requires the use of some combination of the following management options:

- $\quad$ Delist, if approved, soil may be eligible for beneficial re-use;

- $\quad$ Application of the Contained-in Policy;

- $\quad$ Storage;

- Treatment to agreed upon criteria for hazardous constituents specified by appropriate regulatory authorities for beneficial re-use; and

- Treatment to below LDRs with disposal in a Subtitle $\mathrm{C}$ hazardous waste management facility, in compliance with the LDR treatment standard.

If soil samples indicate that the soil is not contaminated with listed hazardous waste or if treatment to agreed upon criteria (detection limits, risk-based criteria, etc.) is achieved ${ }^{1}$ and a characteristic of hazardous waste is not exhibited, management of the soil is unrestricted under RCRA.

\subsubsection{Area of Suspected Contamination, Characteristic Waste}

If a release is suspected within an area where soil will be excavated, soil samples should be collected and an analysis performed for constituents associated with the suspected release.

\footnotetext{
${ }^{1}$ Contained-in Policy, EPA Memorandum, dated November 13, 1986, "if the [soil] is treated such that it no longer contains a hazardous waste, the [soil] would no longer be subject to regulation under Subtitle C of RCRA."
} 
If soil analyses show contamination, appropriate soil management is required. Contamination due to the presence of characteristic hazardous wastes requires the use of some combination of the following management options:

- $\quad$ Storage;

- Application of the Contained-in Policy;

- Treatment to below LDR treatment standards or agreed upon criteria specified by appropriate regulatory authorities and beneficial re-use; and

- Treatment to below LDRs with disposal in a Subtitle $\mathrm{C}$ hazardous waste management facility, in compliance with the LDR treatment standards.

If data indicate that the soil is not contaminated with characteristic hazardous wastes or treatment to below treatment standards is achieved, the management of the soil is unrestricted under RCRA.

\subsection{USING THE TOXIC SUBSTANCES CONTROL ACT DECISION TREE}

TSCA, enacted in 1976, sought to limit manufacture, processing, and distribution in commerce, and control the use, marking, storage, and disposal of PCBs (40 CFR Part 761). To supplement the Act, the PCB Spill Cleanup Policy (40 CFR 761, Subpart G) became effective on May 4, 1987, which addresses spills or releases occurring after May 4, 1987. The PCB Disposal Amendments Rule (63 FR 35384 of June 29, 1998), 40 CFR 761.61, applies to almost all spills or releases and broadened the definition of PCB remediation wastes. Under 40 CFR 761.61, soil contaminated with historical PCB releases at Y-12 is considered as bulk PCB remediation waste. Soil containing non-liquid PCB materials (e.g., paint chips) may be classified as PCB bulk product waste (see Chap. 4). PCB releases prior to April 18, 1978, are excluded from the Disposal Amendments Rule, but are subject to site-by-site evaluation of the EPA Region if a site poses an unreasonable risk [40 CFR 761.50(b)(3)]. Spills between April 1978 and May 1987 may be addressed as bulk PCB remediation wastes or under the Spill Cleanup Policy. Figure 2.5 diagrams the TSCA process for managing PCB-contaminated soil at Y-12.

Identifying the source of a historical spill is important to identifying the management requirements for PCB-contaminated soil and the concentrations that may have been present in any spilled materials (see Sect. 4.2.2). Spills that occurred prior to April 1978 are subject to site-by-site evaluation; however, the concentration of the source of the spill is less likely to be known. More recent spills (after May 1987) will have been closely managed, and information regarding concentration of spilled material may be available. Concentrations of PCBs in the soil, regardless of the time of release, will also affect soil management and disposal decisions.

\subsubsection{Polychlorinated Biphenyl Contamination Due to Unknown Sources}

If the source of the PCBs is unknown, the PCB concentration in the spilled materials cannot be determined. If the PCB levels in the soil equal or exceed 50 part per million (ppm), the soil must be stored and disposed in compliance with TSCA. Contamination due to an unknown source is not likely to be subject to the PCB Spill Policy, but may trigger the self-implementing option for disposition under the Disposal Amendments Rule. Concentrations of PCBs in the soil may be used to determine the proper soil management practices (e.g., beneficial re-use). 
04-120(E)/030205 


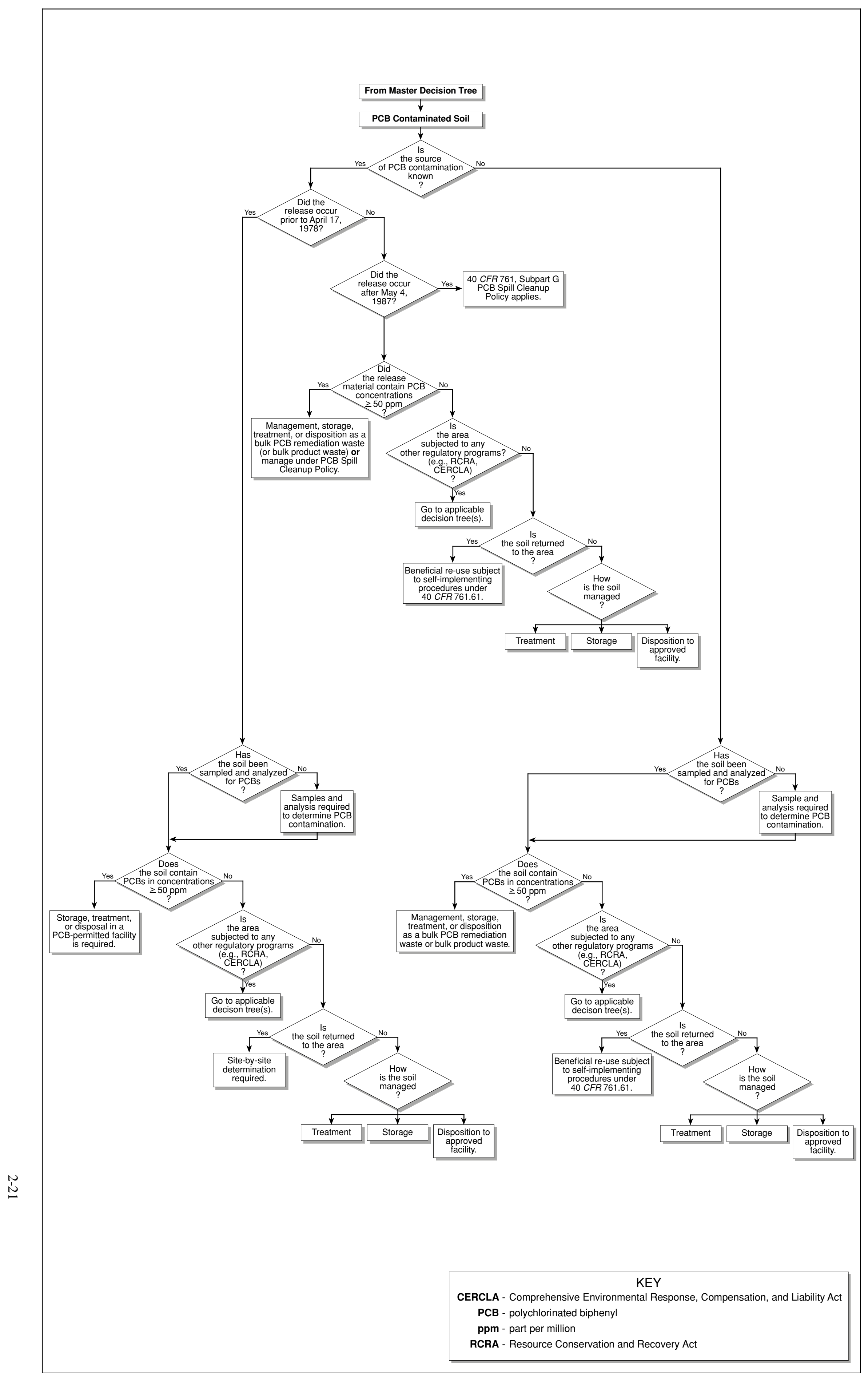




\subsubsection{Polychlorinated Biphenyl Contamination Due to Pre-1978 Spills}

Soil contaminated with PCBs released prior to April 1978 is subject to site-by-site evaluations by EPA. As such, specific management of that soil is subject to the conditions placed on the spill area by the regulatory requirements. Soil PCB concentrations less than $50 \mathrm{ppm}$ may be allowed to be returned to the excavation where remediation activities are planned for the future [40 CFR 761.120(a)(4) and (c)], provided a site-by-site evaluation from EPA has been approved.

\subsubsection{Releases of Polychlorinated Biphenyls Due to Post-1978 Spills}

Soil contaminated with PCBs released between April 1978 and May 1987, may be addressed under either the PCB Spill Cleanup Policy or under the PCB Disposal Amendments Rule. For releases that occurred during this time, the PCB concentration, as well as the source of the spill, will be factors considered in soil management options. Releases occurring after May 4, 1987, are subject to the PCB Spill Cleanup Policy and are fully regulated. Soil with PCB concentrations greater than or equal to $50 \mathrm{ppm}$ must be managed in compliance with the storage and disposal requirements. Beneficial re-use options for soil < $50 \mathrm{ppm}$ PCBs (classified as bulk PCB remediation waste) are dictated by the concentrations present and occupancy of the site.

\subsection{USING THE ATOMIC ENERGY ACT DECISION TREE}

Low-level radioactive wastes or mixed low-level radioactive and RCRA hazardous waste is subject to jurisdiction by the U. S. Department of Energy (DOE) under AEA and is included in the scope of this Plan. Figure 2.6 diagrams the process for managing soil under DOE requirements and AEA regulations.

\subsubsection{Low-Level Radioactive Material}

Soil contaminated with radioactive material should be managed pursuant to applicable DOE rules and orders. Radiologically contaminated soil may be eligible for disposal on-site in the ORR Class II industrial landfills if it contains uranium at levels below $35 \mathrm{pCi} / \mathrm{g}$ (total uranium), passes TDEC screening criteria for 18 radionuclides of concern [uranium isotopes (U-234, U-235, U-238), H-3, C-14, Co-60, Sr-90, Tc-99, Cs-137, Eu-152, Eu-154, Ra-226, Th-230, Th-232, Np-237, Pu-238, Pu-239, or Am-241] (TDEC 2003), and also meets DOE Order 5400.5 surface release criteria. In addition, other COCs must be at concentrations allowed in the on-site disposal units (see Sect. 4.4.1). Soil that can otherwise be returned to an excavated area is not precluded from this action simply due to the presence of low-level radioactive materials. CERCLA includes radionuclides on its Hazardous Substance List (40 CFR 302.4). While CERCLA and EPA have authority over the management of radioactive material/soil at CERCLA sites, the focus of the regulatory activity has been to incorporate or reference DOE- and other AEA-related management standards that already exist.

\subsubsection{Mixed Waste}

Soil known to contain or potentially containing RCRA hazardous waste mixed with radioactive material should be analyzed for indicator parameters based on the types contaminants known or suspected to be present, unless sufficient PK is available to otherwise characterize the soil for management requirements. Based on PK or analytical results, segregation of soil may be appropriate to separate soil containing only radioactive constituents from that containing only hazardous waste contaminations or mixed waste contamination. 


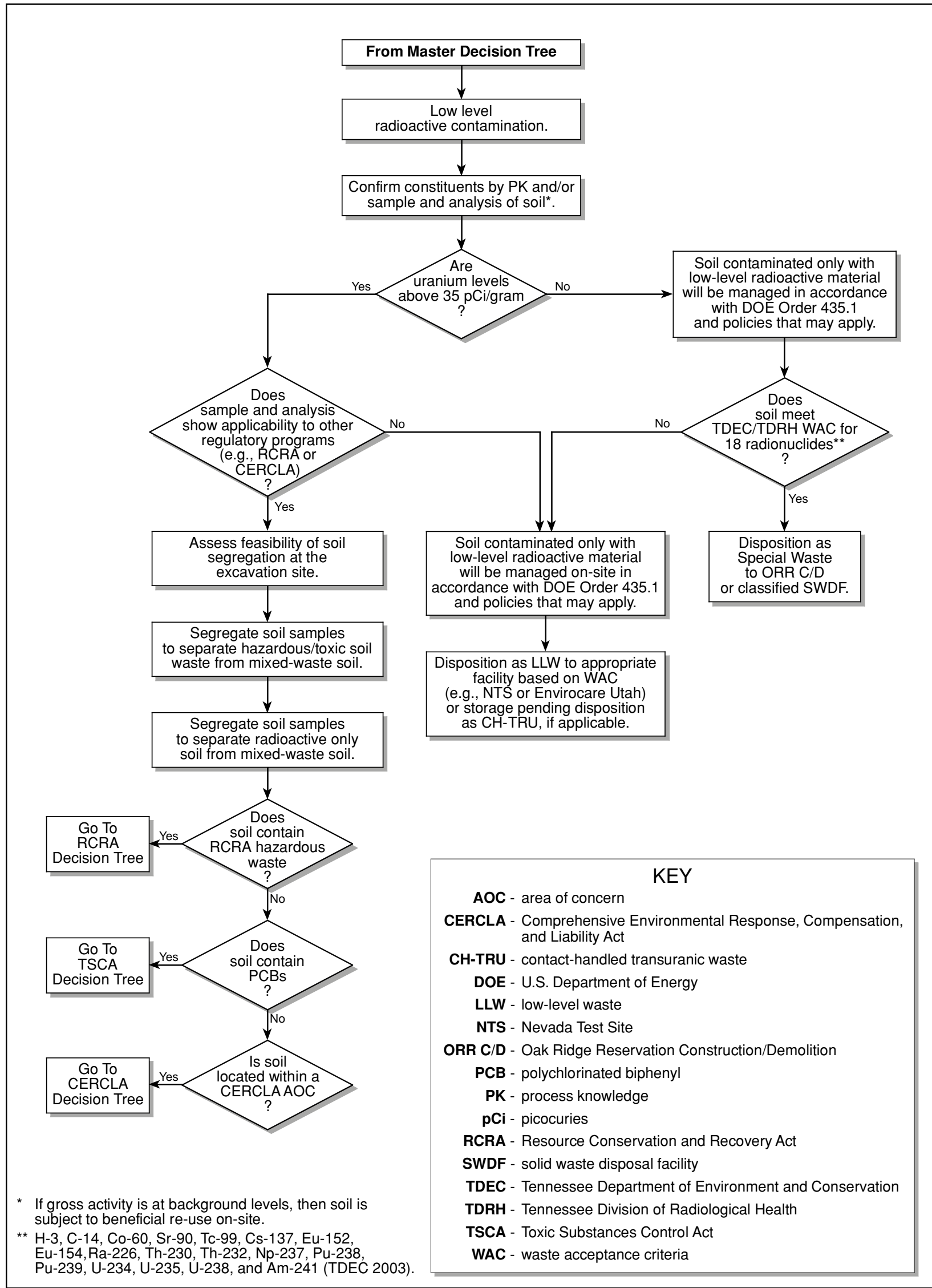

Fig. 2.6. Decision tree for radiologically contaminated soil. 
Where the excavated soil is considered as mixed waste, the applicable regulatory programs will apply. If RCRA hazardous waste is identified, the RCRA decision tree should be reviewed before attempting to manage this soil. Likewise, if PCB contamination is detected, the TSCA decision tree should be reviewed. If the soil contaminated with mixed waste is within a CERCLA OU or AOC, the CERCLA decision tree should be reviewed.

\subsection{USING THE CLEAN AREA DECISION TREE}

For projects to be conducted where contamination is not known or suspected, no specific regulatory requirements apply. Due to the history and nature of operations at the facility, assumptions have been made and conservative policies established to minimize liabilities and to ensure protection of the environment. Figure 2.7 diagrams the process for ensuring that undiscovered contamination is detected and appropriately managed.

\subsubsection{Status of Analytical Data}

Due to the operational history of $\mathrm{Y}-12$, some level of PK and visual assessment for contamination is advisable for each project using available information sources summarized in Chap. 3 of this Plan, CERCLA RI reports, or databases, such as the Oak Ridge Environmental Information System (see Sect. 4.3). The PK process includes professional judgment and consideration of the historical use of the areas and their proximity to any regulated areas. Visual assessment includes observing the project site for signs of stressed vegetation, stained soil, areas where the ground surface has been disturbed, unusual odors, and obvious sources of contamination on the ground surface. Surface water and groundwater (e.g., tributaries, ditches, springs, seeps), if present, should be evaluated for evidence of leaching from soil sources.

When soil excavation or movement will occur in areas not identified under a particular regulatory program and sufficient PK is not available, analyses for indicator parameters may be warranted. Further characterization, if required, may include monitoring or testing with real-time instruments, portable testing kits for certain parameters, and/or collection of screening samples for fixed-base laboratory analysis. Basic indicator parameters include:

- $\quad \mathrm{pH}$ (for soil and water);

- $\quad$ Total gross activity (surface surveys);

- $\quad$ Total petroleum hydrocarbons (> $100 \mathrm{ppm})$;

- Headspace analysis on soils >10 ppm total organics above background using portable photoionization detectors and flame ionization detectors; and

- $\quad H g$ vapor analyzers.

Other more quantitative analyses for metals/inorganics, radiological constituents, and organic compounds may be employed if suspected sources of contamination are present or to check for false positives generated by the initial screening. 


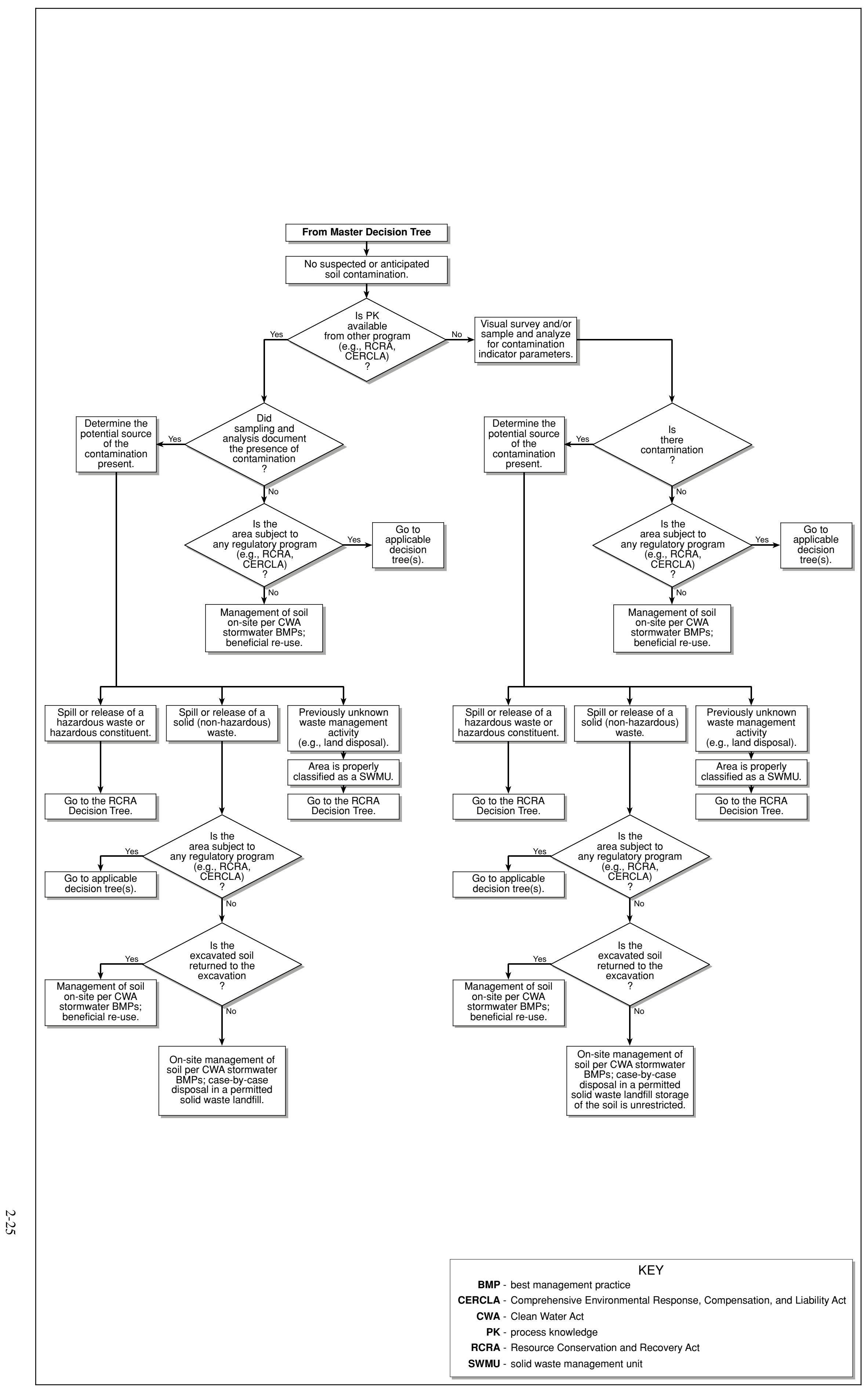




\subsubsection{Absence of contamination}

If contamination is not found and the soil is not located in an area subject to a regulatory program, the soil is subject to beneficial re-use. These conditions also apply to projects that are conducted in regulated locations for which characterization efforts have been completed and a No Further Investigation (NFI)/No Further Action (NFA) status has been obtained (e.g., the site is clean or contaminant levels were below the applicable risk-based screening criteria).

\subsubsection{Indication of contamination}

If contamination is found, the potential source of the contamination must be determined to identify the appropriate soil management requirements that may apply. The presence of contamination would be due to one or a combination of the following three events:

- Previously unknown waste management activity;

- $\quad$ Release of a solid waste; and

- Release of a hazardous waste.

If the soil is within an area subject to a regulatory management program, the applicable decision tree should be reviewed. Where possible, the first preference for soil management under these circumstances is beneficial re-use. If the soil is not subject to beneficial re-use (e.g., excess volume or contaminant levels exceed regulatory requirements), then the management and disposition of the soil would be subject to the requirements of the applicable programmatic and regulatory drivers discussed above and in Chap. 4. 


\section{LEGACY CONTAMINATION AND ENVIRONMENTAL INFRASTRUCTURE}

Planning for soil disturbances at Y-12 and management of excavated soil often involves evaluation of the types of contaminants that may be present and the potential issues related to the regulatory status of a site. Legacy contamination information is useful for supporting PK evaluation, potential IH requirements, and regulatory requirements that may apply. Some remedial decisions deemed protective under CERCLA involve specified land use assumptions (e.g., industrial worker exposure scenario). A major long-term soil disturbance within a CERCLA AOC may require evaluation of risks for a different exposure receptor (e.g., construction worker) than assumed in the decision. This chapter contains reference information, including an overview of the occurrence and distribution of the principal types of soil contamination, and describes completed and planned response actions under a variety of regulatory programs. Locations and the regulatory status for contaminant source areas and waste management units are presented. Unit closures and RAs have also frequently incorporated engineered structures and post-closure or remediation performance monitoring systems that must remain intact and functional for long periods of time. The presence of such infrastructure is also a consideration when planning for soil disturbance activities, and information pertaining to its presence and location is also presented in this chapter. As a precaution, information presented on the occurrence and distribution of principal soil contaminants is derived from historical sources and does not reflect current site conditions.

\subsection{HISTORICAL RESPONSE ACTIONS AND COMPREHENSIVE ENVIRONMENTAL RESPONSE, COMPENSATION, AND LIABILITY ACT DECISIONS}

Y-12 is contaminated by legacy wastes from past operations and waste management practices. Sources of contamination include waste disposal areas, former surface impoundments, leak and spill sites, tanks, buildings, and process pipelines. Investigations of the occurrence and distribution of contaminants in soil have been conducted by numerous organizations under a variety of regulatory drivers, including CERCLA, RCRA, and Tennessee UST regulations, as well as various scientific studies. Waste management unit closures under RCRA and RAs (including NFI/NFA decisions) under CERCLA have been completed for a number of source areas at Y-12. A summary of additional future actions included in the EM Program baseline (as of issuance of this plan) for Y-12 is also presented for each watershed in the Y-12 area of responsibility.

As with investigation phases of work, response actions to date for environmental legacies at Y-12 have been addressed under various regulatory programs, including RCRA, CERCLA, and National Pollutant Discharge Elimination System (NPDES)-related programs [e.g., Reduction of Mercury in Plant Effluent (RMPE)]. In addition, one non-hazardous solid waste disposal facility (SWDF; Centralized Sanitary Landfill II) on Chestnut Ridge is closed, maintained, and monitored in accordance with federal and state solid waste regulations. Future response actions for environmental legacy concerns have been relegated to CERCLA and will be conducted pursuant to the ORR FFA. Detailed descriptions of historical and CERCLA environmental response actions may be found in the Remediation Effectiveness Report (RER), which is updated annually (DOE 2003b). Starting in fiscal year (FY) 2000, and at requisite intervals thereafter, the RER encompasses the formal CERCLA 5-Year Review for completed response actions. 


\subsubsection{Historical Response Actions}

\section{RCRA Programs}

During the mid-1980s through early 1990s, an intensive closure program was implemented, under the auspices of RCRA, to close most of the major former hazardous waste TSD units in the UEFPC and Bear Creek watersheds, as well as sites on Chestnut Ridge. Closure of most of the major former TSD units at Y-12 involved the installation of engineered caps and drainage controls. A leachate collection and treatment system was installed in a portion of the Bear Creek Burial Grounds (BCBG) as part of closure actions. Maintenance of engineered caps and/or long-term groundwater monitoring is required at seven of these closed TSDs under the terms of RCRA post-closure permits for the UEFPC, Chestnut Ridge, and Bear Creek hydrogeologic regimes (Permit Nos. TNHW-113, TNHW-088, and TNHW-116, respectively). A contaminated groundwater plume emanating from the S-3 Ponds and migrating east into Y-12 is also addressed under the post-closure permit for the UEFPC regime. Under the terms of the RCRA post-closure permits, modifications to groundwater monitoring networks or engineered structures require prior approval of TDEC and permit modifications. Table 3.1 lists former TSDs currently regulated under RCRA post-closure requirements. A fourth unit in the Chestnut Ridge administrative area (East Chestnut Ridge Waste Pile) is anticipated to be added to the Chestnut Ridge Hydrogeologic Regime post-closure permit upon its re-issuance (expected in 2005). Locations of closed TSD units are shown on Fig. 3.1.

\section{NPDES and RMPE Programs}

The RMPE Program, conducted in the mid- to late 1990s (DOE 1998), encompassed numerous actions to eliminate sources of mercury to UEFPC. Actions were conducted under two phases. Phase 1 RMPE actions consisted of identifying major mercury sources and completing interim remediation, such as storm sewer inspection, cleaning, relining, and rerouting of process water flows. Additionally, a $2000-\mathrm{ft}$ section of the North-South Pipe, which conveys UEFPC in the western area of the complex, containing mercury-contaminated sediment was abandoned and replaced. Phase 1 RMPE actions were completed in the late 1980s and do not have associated long-term maintenance or performance monitoring requirements.

Phase 2 RMPE actions focused on reducing the migration of residual mercury and meeting the mercury compliance schedule specified in the 1995 NPDES permit. Upon negotiation of the FFA, legacy mercury responses were eventually transferred to CERCLA and the RMPE Program was phased out. Completed Phase 2 actions included eliminating mercury sources and rerouting the process pipe in former mercury-use buildings in the western portion of Y-12. Ongoing components of the Phase 2 RMPE actions include the Lake Reality By-Pass Project, Flow Management in UEFPC, and operation of the East End Mercury Treatment System and Central Mercury Treatment System (CMTS). Additionally, the UEFPC Stream Bank Stabilization Project was implemented wherein runoff controls and rip rap placement along the stream banks was initiated as a CERCLA treatability study and completed in January 2000.

\subsubsection{Comprehensive Environmental Response, Compensation, and Liability Act Actions in the Upper East Fork Poplar Creek Watershed (Y-12 National Security Complex)}

\subsubsection{Completed CERCLA actions}

A total of six CERCLA RAs have been completed to date within the UEFPC watershed (Table 3.2). Locations of these actions are shown on Fig. 3.2. With exception of the Union Valley Interim 
Table 3.1. RCRA post-closure status for former treatment, storage, and disposal units at Y-12

\begin{tabular}{|c|c|c|}
\hline Unit & $\begin{array}{l}\text { Major components of } \\
\text { closure }\end{array}$ & Major post-closure requirements \\
\hline \multicolumn{3}{|c|}{$\begin{array}{c}\text { UEFPC Hydrogeologic Regime } \\
\text { (RCRA Post-Closure Permit No. TNHW-113) }\end{array}$} \\
\hline $\begin{array}{l}\text { Former New Hope } \\
\text { Pond }\end{array}$ & $\begin{array}{l}\text { Engineered cap, UEFPC } \\
\text { distribution channel }\end{array}$ & $\begin{array}{l}\text { Cap inspection and maintenance. } \\
\text { No current groundwater monitoring requirements in lieu of } \\
\text { ongoing CERCLA actions in the eastern portion of Y-12. }\end{array}$ \\
\hline $\begin{array}{l}\text { Eastern S-3 Ponds } \\
\text { Groundwater Plume }\end{array}$ & $\begin{array}{l}\text { None for groundwater } \\
\text { plume, see former S-3 } \\
\text { Ponds (S-3 Site) for source } \\
\text { area closure }\end{array}$ & $\begin{array}{l}\text { Post-closure corrective action monitoring. } \\
\text { Inspection and maintenance of the monitoring network. }\end{array}$ \\
\hline \multicolumn{3}{|c|}{$\begin{array}{l}\text { Chestnut Ridge Hydrogeologic Regime } \\
\text { (RCRA Post-Closure Permit No. TNHW-088) }\end{array}$} \\
\hline $\begin{array}{l}\text { Chestnut Ridge } \\
\text { Security Pits }\end{array}$ & Engineered cap & $\begin{array}{l}\text { Cap inspection and maintenance. } \\
\text { Post-closure corrective action monitoring. } \\
\text { Inspection and maintenance of the monitoring network and } \\
\text { survey benchmarks. }\end{array}$ \\
\hline Kerr Hollow Quarry & $\begin{array}{l}\text { Waste removal, access } \\
\text { controls }\end{array}$ & $\begin{array}{l}\text { Access controls inspection and maintenance. } \\
\text { Post-closure detection monitoring. } \\
\text { Inspection and maintenance of the monitoring network and } \\
\text { survey benchmarks. }\end{array}$ \\
\hline $\begin{array}{l}\text { Chestnut Ridge } \\
\text { Sediment Disposal } \\
\text { Basin }\end{array}$ & Engineered cap & $\begin{array}{l}\text { Cap inspection and maintenance. } \\
\text { Post-closure detection monitoring. } \\
\text { Inspection and maintenance of the monitoring network and } \\
\text { survey benchmarks. }\end{array}$ \\
\hline \multicolumn{3}{|c|}{$\begin{array}{c}\text { Bear Creek Hydrogeologic Regime } \\
\text { (RCRA Post-Closure Permit No. TNHW-116) }\end{array}$} \\
\hline $\begin{array}{l}\text { Former S-3 Ponds } \\
\text { (S-3 Site) }\end{array}$ & $\begin{array}{l}\text { Neutralization and } \\
\text { stabilization of wastes, } \\
\text { engineered cap, and asphalt } \\
\text { cover }\end{array}$ & $\begin{array}{l}\text { Cap inspection and maintenance. } \\
\text { Post-closure corrective action monitoring. } \\
\text { Inspection and maintenance of the monitoring network and } \\
\text { survey benchmarks. }\end{array}$ \\
\hline Oil Landfarm & Engineered cap & $\begin{array}{l}\text { Cap inspection and maintenance. } \\
\text { Post-closure corrective action monitoring. } \\
\text { Inspection and maintenance of the monitoring network and } \\
\text { survey benchmarks. }\end{array}$ \\
\hline $\begin{array}{l}\text { BCBG A, B, and } \\
\text { Walk-In Pits }\end{array}$ & $\begin{array}{l}\text { Engineered cap, leachate } \\
\text { collection system generic } \\
\text { to the burial grounds }\end{array}$ & $\begin{array}{l}\text { Cap inspection and maintenance. } \\
\text { Post-closure corrective action monitoring. } \\
\text { Inspection and maintenance of the monitoring network and } \\
\text { survey benchmarks. }\end{array}$ \\
\hline
\end{tabular}

CERCLA = Comprehensive Environmental Response, Compensation, and Liability Act.

RCRA $=$ Resource Conservation and Recovery Act.

UEFPC $=$ Upper East Fork Poplar Creek.

Y-12 = Y-12 National Security Complex. 
04-120(E)/030205 


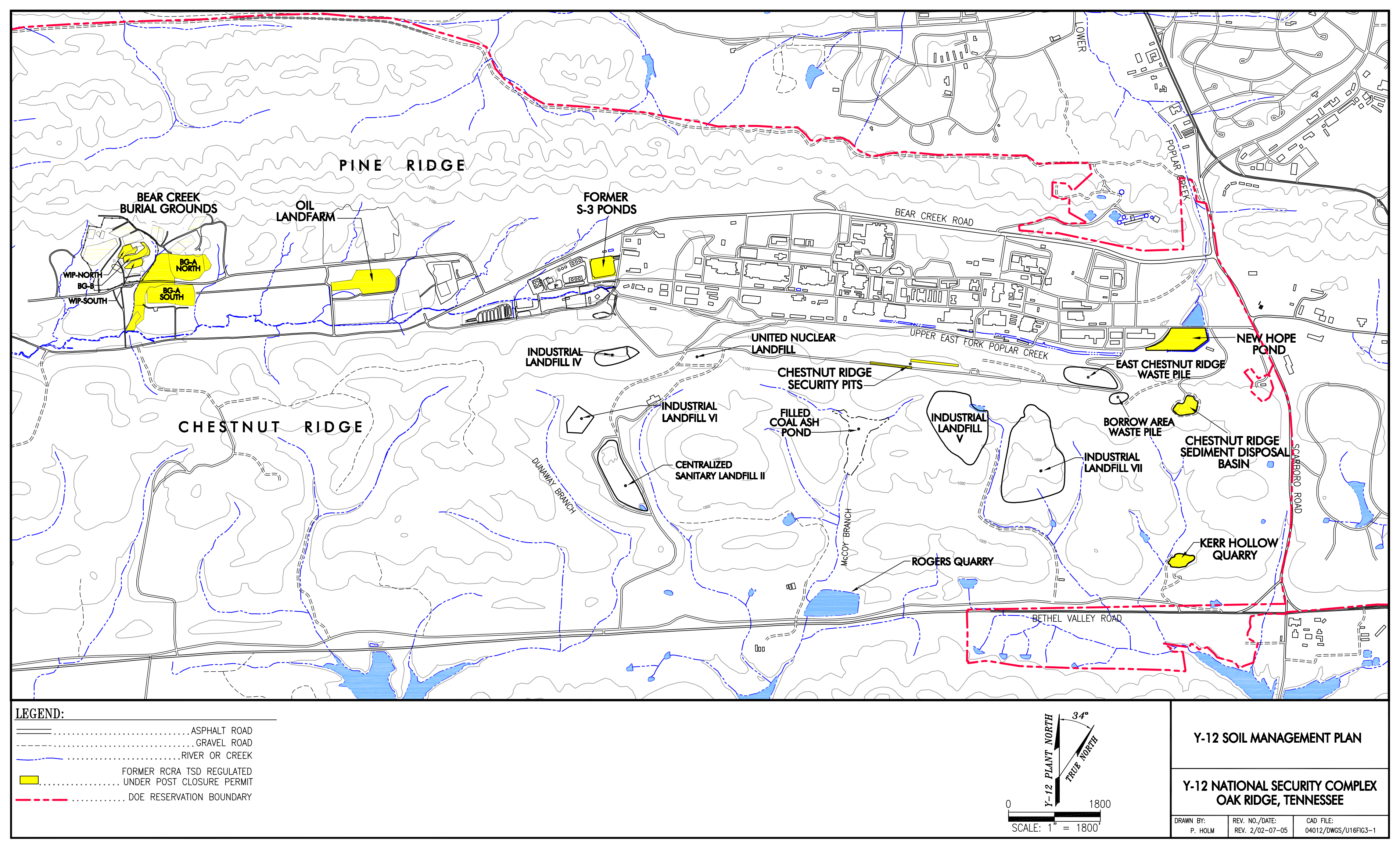


Table 3.2. Summary of completed and ongoing CERCLA response actions in the UEFPC Watershed

\begin{tabular}{|c|c|c|c|c|}
\hline Site/project & Summary of selected remedy & $\begin{array}{l}\text { Summary of performance } \\
\text { goals }\end{array}$ & $\begin{array}{l}\text { Monitoring/stewardship } \\
\text { requirements }\end{array}$ & $\begin{array}{l}\text { Reference for } \\
\text { monitoring/stewardship } \\
\text { requirements }\end{array}$ \\
\hline \multirow[t]{6}{*}{$\begin{array}{l}\text { Phase I ROD for } \\
\text { Interim Source } \\
\text { Control Actions } \\
\text { (Ongoing) }\end{array}$} & Station 17. & $\begin{array}{l}\text { Watershed performance goal: } 200 \\
\text { ppt total mercury in surface water at } \\
\text { Station } 17 . \text { Achieve reduction of } \\
\text { mercury in fish tissue in UEFPC. }\end{array}$ & $\begin{array}{l}\text { Surface water monitoring: } \\
\text { - } \quad \text { Station } 17 . \\
\text { Mercury in stoneroller } \\
\text { minnows (whole body), } \\
\text { redbreast sunfish fillets, } \\
\text { and largemouth bass fillets } \\
\text { at EFK 23.4. }\end{array}$ & $\begin{array}{l}\text { Record of Decision for Phase I } \\
\text { Interim Source Control Actions } \\
\text { in the Upper East Fork Poplar } \\
\text { Creek Characterization Area at } \\
\text { the Oak Ridge } \\
\text { Y-12 Plant DOE/OR/ 01- } \\
\text { 1951\&D3. }\end{array}$ \\
\hline & $\begin{array}{l}\text { Removal of contaminated sediments and bank } \\
\text { soils from UEFPC and Lake Reality to reduce } \\
\text { mercury levels. }\end{array}$ & $\begin{array}{l}70 \text { percent flux reduction within } \\
\text { UEFPC at Station } 8 \text { and achieve } \\
\text { performance goal at Station } 17 \text {. }\end{array}$ & Station 8. & \\
\hline & $\begin{array}{l}\text { WEMA: } \\
\text { - Install } 3.5 \text { acres of asphalt caps over } \\
\text { mercury runoff areas. } \\
\text { - } \quad \text { Flush contaminated sediments from } \\
\text { storm sewers. } \\
\text { - } \quad \begin{array}{l}\text { Reline or replace storm sewers as } \\
\text { needed. }\end{array}\end{array}$ & $\begin{array}{l}50 \text { percent mercury flux reduction in } \\
\text { WEMA discharges (Outfalls } 150 \text {, } \\
160,162 \text {, and 169). }\end{array}$ & Outfalls 150, 160, 163, and 169. & \\
\hline & $\begin{array}{l}\text { Continued operation of CMTS pending } \\
\text { demonstration of remedy effectiveness in the } \\
\text { WEMA. }\end{array}$ & $\begin{array}{l}\text { NPDES discharge limits and } 200 \mathrm{ppt} \\
\text { total mercury at CMTS discharge } \\
\text { (Outfall 551). }\end{array}$ & CMTS discharge (Outfall 551). & \\
\hline & $\begin{array}{l}\text { Building 9201-2 WTS: } \\
\text { - } \quad \text { Treatment of groundwater discharge } \\
\text { from Outfall 51. } \\
\text { - } \quad \text { Treatment of groundwater collected in } \\
\text { dewatering sumps in Bldg. } 9201-2\end{array}$ & $\begin{array}{l}\text { WTS goals: } \\
\text { - } \quad \text { NPDES discharge limits and } \\
\text { 200 ppt total mercury at WTS } \\
\text { discharge point (TBD). } \\
\text { - } \quad \text { building 9201-2 WTS achieves } \\
\text { state and federal air emission } \\
\text { standards. } \\
\text { - Achieve Bldg. 9201-2 WTS } \\
\text { 95\% mercury mass removal. }\end{array}$ & $\begin{array}{l}\text { WTS monitoring: } \\
\text { - } \quad \text { Building 9201-2 WTS } \\
\text { water discharges upon } \\
\text { completion. } \\
\text { - } \text { Building 9201-2 WTS air } \\
\text { emissions upon } \\
\text { completion per system } \\
\text { specifications. }\end{array}$ & \\
\hline & $\begin{array}{l}\text { Continued operation of EEMTS pending } \\
\text { completion of the Bldg. 9201-2 WTS. }\end{array}$ & $\begin{array}{l}\text { NPDES discharge limits and } 200 \mathrm{ppt} \\
\text { total mercury at EEMTS discharge } \\
\text { (Outfall 550). }\end{array}$ & $\begin{array}{l}\text { EEMTS discharge } \\
\text { (Outfall 550). }\end{array}$ & \\
\hline
\end{tabular}


Table 3.2 (continued)

\begin{tabular}{|c|c|c|c|c|}
\hline Site/project & Summary of selected remedy & $\begin{array}{c}\text { Summary of performance } \\
\text { goals }\end{array}$ & $\begin{array}{l}\text { Monitoring/stewardship } \\
\text { requirements }\end{array}$ & $\begin{array}{l}\text { Reference for } \\
\text { monitoring/stewardship } \\
\text { requirements }\end{array}$ \\
\hline $\begin{array}{l}\text { Phase I ROD for } \\
\text { Interim Source } \\
\text { Control Actions } \\
\text { (continued) }\end{array}$ & Land Use Controls/Monitoring. & & $\begin{array}{l}\text { Property record restrictions } \\
\text { and notices, zoning notices for } \\
\text { the WEMA. Continuation of } \\
\text { the ongoing excavation/ } \\
\text { penetration permit program. } \\
\text { Continuation of signs, } \\
\text { postings, and security controls } \\
\text { to limit unauthorized access. } \\
\text { Monitoring of above-listed } \\
\text { stations. }\end{array}$ & \\
\hline $\begin{array}{l}\text { Mercury Tanks } \\
\text { Interim Remedial } \\
\text { Action }\end{array}$ & $\begin{array}{l}\text { Cleaning tanks and rerouting storm sewers } \\
\text { and process pipelines in conjunction with } \\
\text { RMPE Phase } 1 \text { actions. }\end{array}$ & $\begin{array}{l}\text { Reduce the amount of mercury- } \\
\text { contaminated sediment and } \\
\text { elemental mercury entering the } \\
\text { storm sewer system from the three } \\
\text { former tanks. }\end{array}$ & $\begin{array}{l}\text { None following the removal } \\
\text { action. }\end{array}$ & $\begin{array}{l}\text { Record of Decision, Interim } \\
\text { Action for the Mercury Tank } \\
\text { Remediation, DOE/OR/02- } \\
1164 .\end{array}$ \\
\hline $\begin{array}{l}\text { Plating Shop } \\
\text { Container Areas }\end{array}$ & $\begin{array}{l}\text { NFA. Risks below the range of concern for } \\
\text { the current and future industrial land use } \\
\text { exposure scenarios. }\end{array}$ & NA & NA & $\begin{array}{l}\text { Record of Decision for the } \\
\text { Y-12 Plating Shop Container } \\
\text { Areas, Oak Ridge Y-12 Plant, } \\
\text { Oak Ridge, Tennessee, } \\
\text { DOE/OR-1049\&D3. }\end{array}$ \\
\hline $\begin{array}{l}\text { Abandoned Nitric } \\
\text { Acid Pipeline } \\
\text { (UEFPC OU 2) }\end{array}$ & NFA & NA & NA & $\begin{array}{l}\text { Record of Decision for the } \\
\text { Upper East Fork Poplar Creek } \\
\text { Operable Unit } 2 \text { (Abandoned } \\
\text { Nitric Acid Pipeline) at the } \\
\text { Oak Ridge Y-12 Plant, Oak } \\
\text { Ridge, Tennessee, } \\
\text { DOE/OR/02-1265\&D2. }\end{array}$ \\
\hline $\begin{array}{l}\text { Building 9201-4 } \\
\text { Exterior Process } \\
\text { Piping }\end{array}$ & $\begin{array}{l}\text { Removal of former mercury and hydrogen } \\
\text { feed lines from Bldg. 9201-4. }\end{array}$ & $\begin{array}{l}\text { Remove mercury feed and } \\
\text { hydrogen lines to reduce the risk } \\
\text { that a mercury release poses to } \\
\text { human health and the environment. }\end{array}$ & $\begin{array}{l}\text { None following the removal } \\
\text { action. }\end{array}$ & $\begin{array}{l}\text { Action Memorandum for } \\
\text { Building 9201-4, Exterior } \\
\text { Process Piping Removal at the } \\
\text { Y-12 Plant, Oak Ridge, } \\
\text { Tennessee, DOE/OR/02- } \\
\text { 1571\&D2. }\end{array}$ \\
\hline
\end{tabular}




\begin{tabular}{|c|c|c|c|c|}
\hline Site/project & Summary of selected remedy & $\begin{array}{l}\text { Summary of performance } \\
\text { goals }\end{array}$ & $\begin{array}{l}\text { Monitoring/stewardship } \\
\text { requirements }\end{array}$ & $\begin{array}{l}\text { Reference for } \\
\text { monitoring/stewardship } \\
\text { requirements }\end{array}$ \\
\hline $\begin{array}{l}9822 \text { Sediment } \\
\text { Basin and } \\
\text { Bldg. 81-10 Sump } \\
\text { Removal Action }\end{array}$ & Removal of contaminated sediment. & $\begin{array}{l}\text { Reduce health and environmental } \\
\text { risks associated with the release of } \\
\text { contaminants from the } 9822 \\
\text { Sediment Basin and the Bldg. } 81- \\
10 \text { Sump. }\end{array}$ & $\begin{array}{l}\text { None following the removal } \\
\text { action. }\end{array}$ & $\begin{array}{l}\text { Action Memorandum for the } \\
\text { Y-12 Plant } 9822 \text { Sediment } \\
\text { Basin and Building } 81-10 \\
\text { Sump, Oak Ridge, Tennessee, } \\
\text { DOE/OR/01-1716\&D1. }\end{array}$ \\
\hline $\begin{array}{l}\text { Y-12 Plant East } \\
\text { End VOC Plume } \\
\text { Removal Action } \\
\text { (ongoing) }\end{array}$ & $\begin{array}{l}\text { Interception (groundwater pumping and } \\
\text { treatment system) of the groundwater } \\
\text { contaminant plume to prevent migration off } \\
\text { of the ORR east into Union Valley. }\end{array}$ & $\begin{array}{l}\text { Reduce health and environmental } \\
\text { risks associated with the migration } \\
\text { of VOC-contaminated groundwater } \\
\text { from the east end of the Y-12 and } \\
\text { reduce the potential risk from } \\
\text { exposure to this contamination in } \\
\text { off-site areas. }\end{array}$ & $\begin{array}{l}\text { Maintenance and operation of } \\
\text { the treatment system } \\
\text { (Bldg. 9422-22). Monitoring } \\
\text { of treatment system influent, } \\
\text { effluent, and air emissions. } \\
\text { Monitoring of groundwater at } \\
\text { the east end of Y-12 (wells } \\
\text { GW-154 and -722) and in } \\
\text { Union Valley (wells GW-169, } \\
-170 \text {, and -232). }\end{array}$ & $\begin{array}{l}\text { Action Memorandum for the } \\
\text { Oak Ridge Y-12 Plant East } \\
\text { End Volatile Organic } \\
\text { Compound Plume, Oak Ridge, } \\
\text { Tennessee, DOE/OR/01- } \\
\text { 1819\&D2. }\end{array}$ \\
\hline $\begin{array}{l}\text { Union Valley } \\
\text { Interim Remedial } \\
\text { Action }\end{array}$ & $\begin{array}{l}\text { Property owner notifications, groundwater } \\
\text { use restrictions, and an annual deed search. }\end{array}$ & $\begin{array}{l}\text { Ensure public health is protected } \\
\text { while final actions are being } \\
\text { developed and implemented. } \\
\text { Identify and, if necessary, prohibit } \\
\text { future activities with a potential to } \\
\text { accelerate the rate of contaminant } \\
\text { migration from the CA or increase } \\
\text { the extent of the contaminant } \\
\text { plume. }\end{array}$ & $\begin{array}{l}\text { Annual deed searches and } \\
\text { notifications to new property } \\
\text { owners. }\end{array}$ & $\begin{array}{l}\text { Record of Decision for an } \\
\text { Interim Action for Union } \\
\text { Valley, Upper East Fork } \\
\text { Poplar Creek Characterization } \\
\text { Area, Oak Ridge, Tennessee, } \\
\text { DOE/OR/02-1545\&D2. }\end{array}$ \\
\hline
\end{tabular}


Table 3.2 (continued)

\begin{tabular}{|c|c|c|c|c|}
\hline Site/project & Summary of selected remedy & $\begin{array}{c}\text { Summary of performance } \\
\text { goals }\end{array}$ & $\begin{array}{c}\text { Monitoring/stewardship } \\
\text { requirements }\end{array}$ & $\begin{array}{l}\text { Reference for } \\
\text { monitoring/stewardship } \\
\text { requirements }\end{array}$ \\
\hline $\begin{array}{l}\text { Lead Source } \\
\text { Removal of } \\
\text { Former YS-860, } \\
\text { Firing Ranges } \\
\text { Removal Action }\end{array}$ & Soil removal. & $\begin{array}{l}\text { Protect human health and the } \\
\text { environment from the lead } \\
\text { contamination source and } \\
\text { achievement of a risk-based } \\
\text { cleanup level of } 1400 \mathrm{ppm}(\mu \mathrm{g} / \mathrm{g}) \\
\text { lead in soil based on a recreational } \\
\text { scenario. }\end{array}$ & $\begin{array}{l}\text { None following the removal } \\
\text { action. }\end{array}$ & $\begin{array}{l}\text { Action Memorandum for Lead } \\
\text { Source Removal at the Former } \\
\text { YS-860 Firing Ranges, Y-12 } \\
\text { Plant, Oak Ridge, Tennessee, } \\
\text { DOE/OR/02-1622\&D1. }\end{array}$ \\
\hline
\end{tabular}

$\mathrm{CA}=$ characterization area

CERCLA = Comprehensive Environmental Response, Compensation, and Liability Act.

CMTS $=$ Central Mercury Treatment System.

EEMTS = East End Mercury Treatment System.

$\mathrm{NA}=$ not applicable

$\mathrm{NFA}=$ no further action.

NPDES = National Pollutant Discharge Elimination System

$\mathrm{OU}=$ operable unit.

ORR = Oak Ridge Reservation

ppm $=$ part per million

$\mathrm{ppt}=$ part per trillion.

RMPE $=$ Reduction of Mercury in Plant Effluent (program).

ROD $=$ record of decision.

$\mathrm{TBD}=$ to be determined.

UEFPC $=$ Upper East Fork Poplar Creek

$\mathrm{VOC}=$ volatile organic compound.

WEMA = West End Mercury Area

WTS $=$ Water Treatment System

Y-12 = Y-12 National Security Complex. 
04-120(E)/030205 


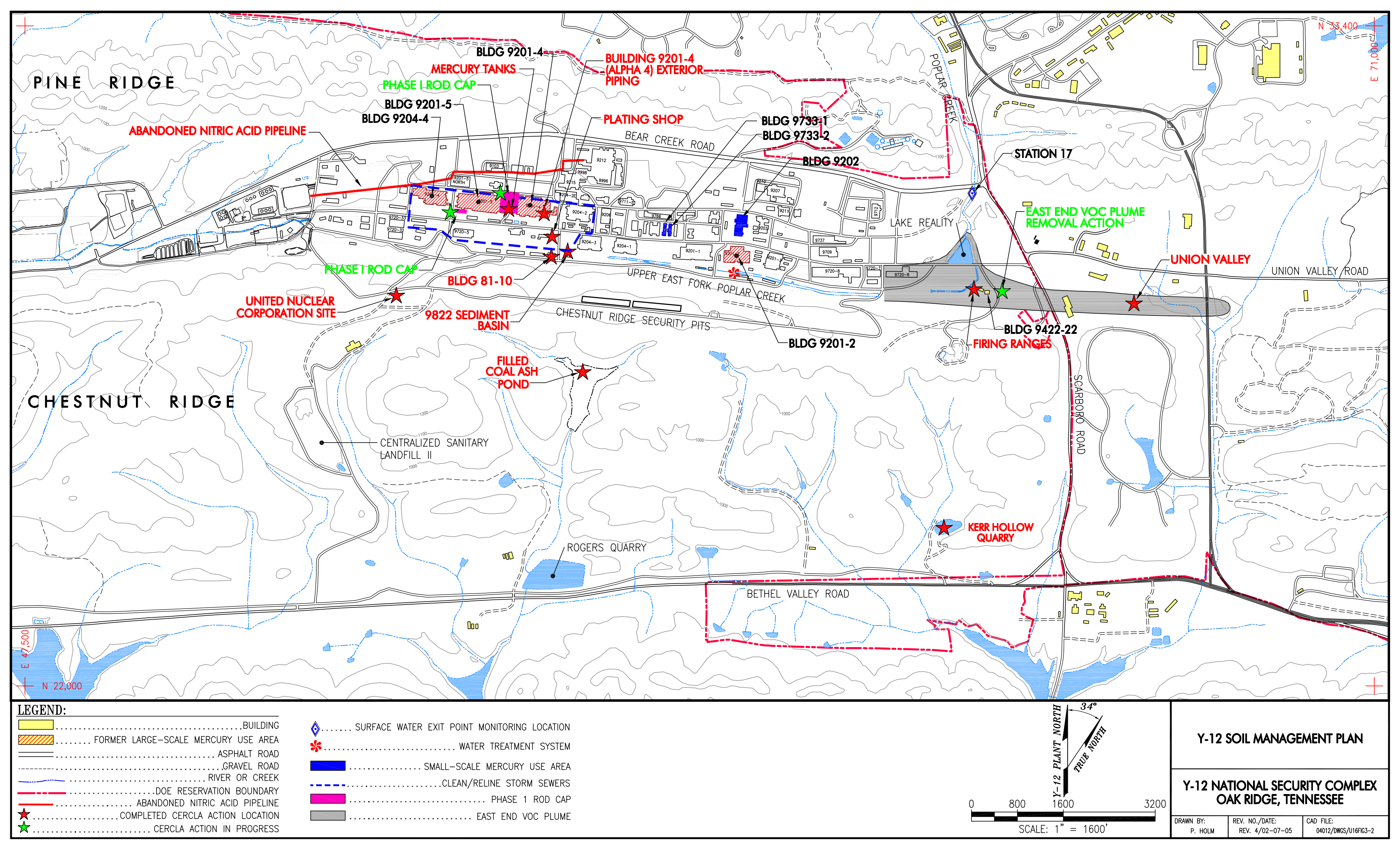

Fig. 3.2. Locations of former RMPE actions and completed and ongoing CERCLA response actions in the UEFPC Watershed and Chestnut Ridge administrative area. 
Record of Decision (ROD), these completed actions are removal actions or NFA decisions and have no post-remediation performance or stewardship requirements (e.g., maintenance of engineered controls or access restrictions) other than general provisions of the UEFPC LUCIP, which are currently in preparation. The Union Valley Interim ROD involves off-site areas and includes only administrative requirements. Although these actions do not have long-term monitoring or maintenance requirements, planning for potential soil disturbances within these areas must consider the basis for the decisions at the time they were made, including, as applicable, assumptions regarding likely future land use, risk exposure scenarios, and clean up levels. These considerations especially apply to the Abandoned Nitric Acid Pipeline, Plating Shop Container Areas, and the former YS-860 Firing Ranges decisions, which were based on specific land use and exposure assumptions. Changes in the land use basis as a result of any future major soil disturbance could result in the decision being no longer protective.

\subsubsection{Ongoing CERCLA response actions}

As of FY 2004, two multi-component CERCLA actions were ongoing within the UEFPC Watershed: the Phase I interim source control actions for mercury source areas (Phase I ROD) and the Y-12 East End Volatile Organic Compound (VOC) Plume (EEVOC) removal action (see Table 3.2). The Phase I ROD for mercury source areas has the most implications relative to soil disturbance. The EEVOC removal action involves groundwater remediation and is a consideration only from the perspective of utilities and infrastructure associated with the action.

\section{Phase I Interim Source Control Actions}

The Phase I ROD, signed in May 2002, includes a combination of source control and receptor media (e.g., sediment in the UEFPC) remedies designed to reduce mercury loading within the UEFPC at the watershed scale. Source control actions under the scope of the ROD will include: (1) capping exposed mercury-contaminated soils in the West End Mercury Area (WEMA), (2) cleaning and re-lining contaminated storm sewers, and (3) treating point discharges to the UEFPC (Outfall 51 and Bldg. 9201-2 dewatering sumps). Receptor media to be addressed include removing contaminated sediment from portions of the UEFPC main channel and from Lake Reality (Fig. 3.2).

A LUCIP is in preparation in conjunction with the Phase I ROD, which proposes protective actions to reduce the risk of human exposure to contaminants. Because Y-12 is an active installation, many of the protective elements of the LUCIP are in place. The LUCIP specifies property record restrictions, property record notices, and zoning notices for the WEMA in Y-12. Continuation of the Y-12 excavation/penetration permit program is cited as a control to regulate unauthorized excavations of potentially contaminated areas. Signs and continuation of security patrols provide protection to reduce the risk of exposure of unauthorized personnel to surface water within the UEFPC. Negotiation of land use controls is ongoing as of the date of issue of this Soil Management Plan and has not been implemented and is subject to revision.

Evaluating the overall effectiveness of the Phase I actions will be achieved through a watershed-level remedial performance standard, 200 part per trillion (ppt), for total aqueous mercury in surface water at the watershed integration point (Station 17; Fig. 3.2). Other key components of the Phase I ROD also have performance standards and goals based on expected outcomes of individual components of the remedy. Measuring the progress toward attainment of these goals is done through monitoring selected interior outfalls and UEFPC mainstem locations and evaluating data with respect to quantitative or semiquantitative measures of the expected outcomes (Table 3.2). These performance standards represent an additional consideration when evaluating BMPs for runoff controls from soil disturbance sites, particularly in former mercury use areas. 


\section{East End VOC Plume Removal Action}

At the east end of Y-12, a plume of contaminated groundwater (e.g., carbon tetrachloride, chloroform, and other chlorinated compounds) extends from the eastern UEFPC Watershed through Union Valley, where it discharges to springs (i.e., SCR 7.1SP and former Spring SCR 7.18SP) in the Scarboro Creek headwaters near Illinois Avenue. A non-time-critical removal action was initiated in FY 1998 to contain the plume through installation of a groundwater extraction well (GW-845) and treatment of pumped groundwater with discharge to UEFPC. Construction of action components was completed in October 2000. Treatment of groundwater to remove particulates, iron, manganese, and VOCs is conducted using an automated filtration and air stripper system housed in Bldg. 9422-22 east of the former New Hope Pond (Fig. 3.2). Influent piping systems from the extraction well to the treatment building and effluent piping from the treatment building to UEFPC were installed. Electrical service, both above and below grade, is present in the immediate vicinity of the treatment building and pumping well. An additional ongoing component of the remedy includes evaluation of in situ bioremediation to enhance or replace the pump-and-treat technology. Installation of a new multi-port monitoring well southeast of Bldg. 9720-6 was completed in the fall of 2002 as part of this study. The well will be used to introduce bioamendments to the groundwater system and to monitor results.

\subsubsection{Future CERCLA actions}

Future decisions in the UEFPC Watershed will address the other principal COCs in the UEFPC, as well as environmental media not covered by the completed or ongoing responses noted above. These future actions are intended to address contaminated soil within Y-12, additional mercury source controls, integrated actions for UEFPC and Lower East Fork Poplar Creek (LEFPC) surface water, and a final groundwater decision.

\section{UEFPC Soils Interim ROD}

The most significant future decision from a soil management perspective is the future UEFPC soils interim ROD, which will address contaminated soils areas in Y-12, scrap metal removal at the Salvage Yard, and soil remediation at Bldg. 9201-2. A focused feasibility study (FFS) addressing UEFPC soils was issued in September 2003 (DOE 2003a); the attendant proposed plan is scheduled for September 2004. Accordingly remediation levels in association with this CERCLA action are considered preliminary as of the date of issue of this Soil Management Plan. The FFS only evaluated a no action alternative and a soil/scrap material removal alternative with disposal in the Bear Creek Environmental Management Waste Management Facility (EMWMF).

The soil/scrap removal alternative, if selected as the preferred remedy in the pending interim ROD, will involve removal of soil containing radionuclides, cadmium, mercury, and total uranium at concentrations above selected risk and chemical hazard thresholds for an industrial worker receptor (Table 3.3). An estimated 25,000 to $40,000 \mathrm{yds}^{3}$ of contaminated soil will require excavation (Figs. 3.3 and 3.4) to a maximum depth of $2 \mathrm{ft}$ with backfilling using clean soil. Some mercury-contaminated soil in the basement of Bldg. 9201-2 to depths up to $5 \mathrm{ft}$ below the basement grade will also require excavation. Contaminated subsurface structures (e.g., basements and pipelines) may also require remediation should contaminant levels exceed risk thresholds. A key element associated with the soil removal alternative is soil accessibility. Under this alternative, currently accessible soil (e.g., not under buildings, critical active roads, and critical active utilities) will be addressed initially. However, the alternative includes provisions for evaluation and future removal of soil that becomes accessible in the future. For future activities within Y-12 that would decrease accessibility to soil, the condition of the surface soil would be assessed and actions taken as necessary. Deeper soil would be institutionally controlled to prevent unacceptable access. 
Table 3.3. Primary actions under a Soil Removal Alternative, UEFPC focused feasibility study

\begin{tabular}{|c|c|c|c|c|}
\hline Problem & Remedial actions & Protection goals & $\begin{array}{c}\text { Demonstration of } \\
\text { effectiveness }\end{array}$ & $\begin{array}{l}\text { Performance } \\
\text { standards }\end{array}$ \\
\hline \multicolumn{5}{|c|}{ Probable conditions and base actions } \\
\hline $\begin{array}{l}\text { Radiological/PCB/ } \\
\text { metal-contaminated } \\
\text { surface soil and } \\
\text { buried waste }\end{array}$ & $\begin{array}{l}\text { Excavation and disposal } \\
\text { in the EMWMF. }\end{array}$ & $\begin{array}{l}\text { Protect the } \\
\text { site-specific } \\
\text { industrial user. }\end{array}$ & $\begin{array}{l}\text { Residual soil below } \\
\text { remediation levels. }\end{array}$ & $\begin{array}{l}\text { Average and maximum } \\
\text { remediation levels. }\end{array}$ \\
\hline $\begin{array}{l}\text { Mercury-contaminated } \\
\text { soil }\end{array}$ & $\begin{array}{l}\text { Excavation and disposal } \\
\text { in the EMWMF. }\end{array}$ & $\begin{array}{l}\text { Protect groundwater } \\
\text { and adjacent surface } \\
\text { water. }\end{array}$ & $\begin{array}{l}\text { Residual soil below } \\
\text { remediation levels. }\end{array}$ & $\begin{array}{l}\text { Groundwater and } \\
\text { surface water protection } \\
\text { remediation levels (less } \\
\text { than } 200 \text { part per } \\
\text { trillion mercury at } \\
\text { Station } 17 \text { ). }\end{array}$ \\
\hline Scrap & $\begin{array}{l}\text { Removal and disposal } \\
\text { in the EMWMF. }\end{array}$ & $\begin{array}{l}\text { Protect the } \\
\text { site-specific } \\
\text { industrial user. }\end{array}$ & All scrap removed. & None. \\
\hline \multicolumn{5}{|c|}{ Reasonable deviations and contingent actions } \\
\hline Subsurface structures & $\begin{array}{l}\text { Removal or } \\
\text { decontamination and } \\
\text { disposal in the } \\
\text { EMWMF. }\end{array}$ & $\begin{array}{l}\text { Protect the } \\
\text { site-specific } \\
\text { industrial user, } \\
\text { groundwater, and } \\
\text { adjacent surface } \\
\text { water. }\end{array}$ & $\begin{array}{l}\text { Subsurface } \\
\text { structures below } \\
\text { remediation levels. }\end{array}$ & $\begin{array}{l}\text { Average and maximum } \\
\text { remediation levels; } \\
\text { groundwater protection } \\
\text { remediation levels. }\end{array}$ \\
\hline $\begin{array}{l}\text { Soil contaminated } \\
\text { with COCs }\end{array}$ & $\begin{array}{l}\text { Excavation and disposal } \\
\text { of soil > leaching } \\
\text { criteria in the } \\
\text { EMWMF. }\end{array}$ & $\begin{array}{l}\text { Protect groundwater } \\
\text { and adjacent surface } \\
\text { water. }\end{array}$ & $\begin{array}{l}\text { Residual soil below } \\
\text { remediation levels. }\end{array}$ & $\begin{array}{l}\text { Groundwater protection } \\
\text { remediation levels } \\
\text { (industrial use goals at } \\
\text { risk level of } 10^{-4} \text { and } \\
\text { hazard index }=1.0 \text { ). }\end{array}$ \\
\hline
\end{tabular}

COCs $=$ Constituents of concern.

EMWMF = Environmental Management Waste Management Facility.

$\mathrm{PCB}=$ polychlorinated biphenyl.

$\mathrm{UEFPC}=$ Upper East Fork Poplar Creek.

$\mathrm{VOC}=$ volatile organic compound.

In addition, the alternative includes an RA objective to protect surface water and groundwater through evaluation of soil sources using numerical modeling and identifying any areas that may require remediation. For surface water protection, any soil mass that is modeled and could cause an exceedance of $200 \mathrm{ppt}$ mercury in surface water at Station 17 would be removed. For groundwater protection, any soil mass for which existing COCs are modeled to leach to groundwater at concentrations greater than industrial drinking water standards (risk $>10^{-4}$ or hazard index $>1$ ) would be removed. 


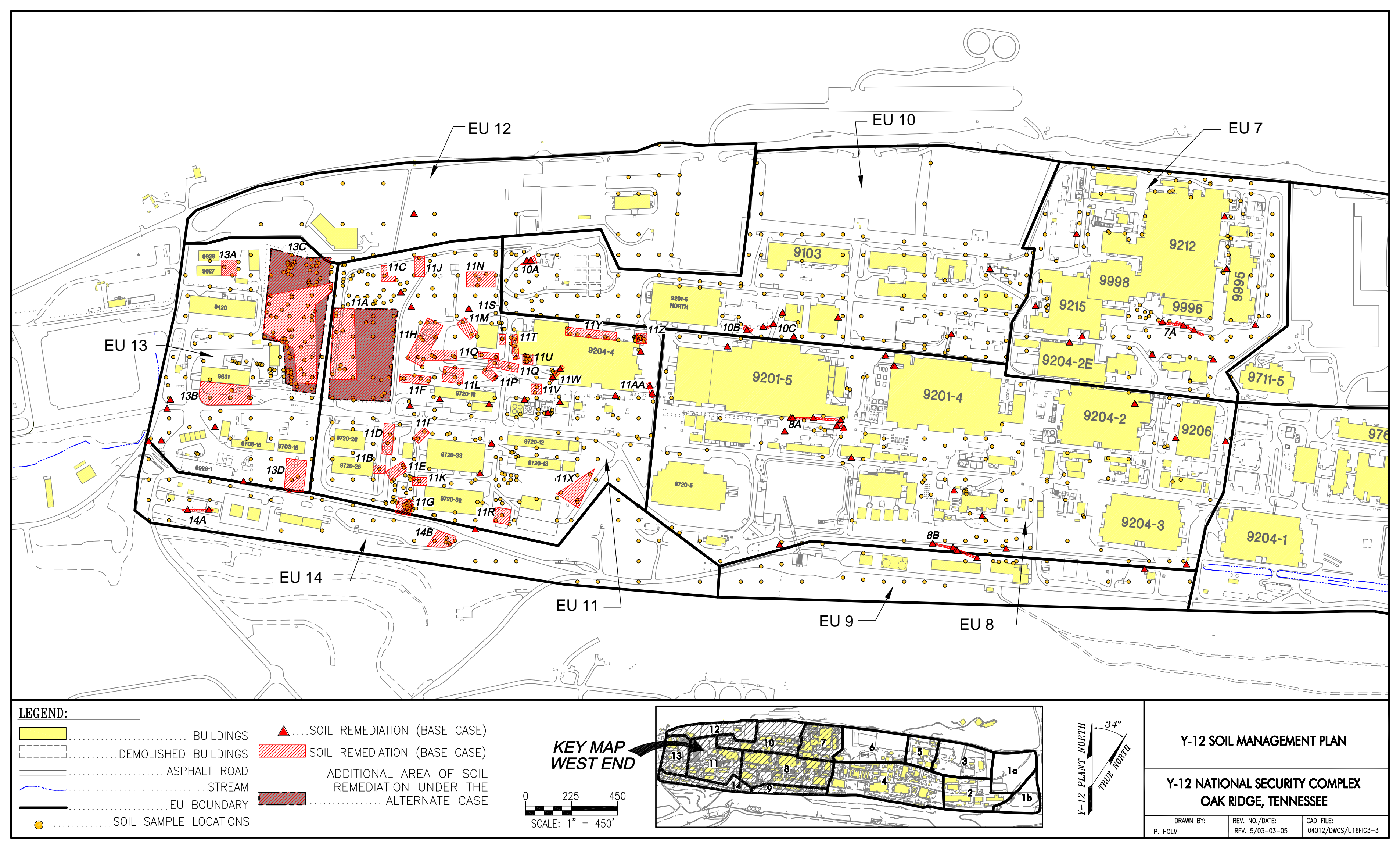

Fig. 3.3. Estimated areas of soil excavation in the western Y-12 area under a soil removal alternative, UEFPC Focused Feasibility Study. 


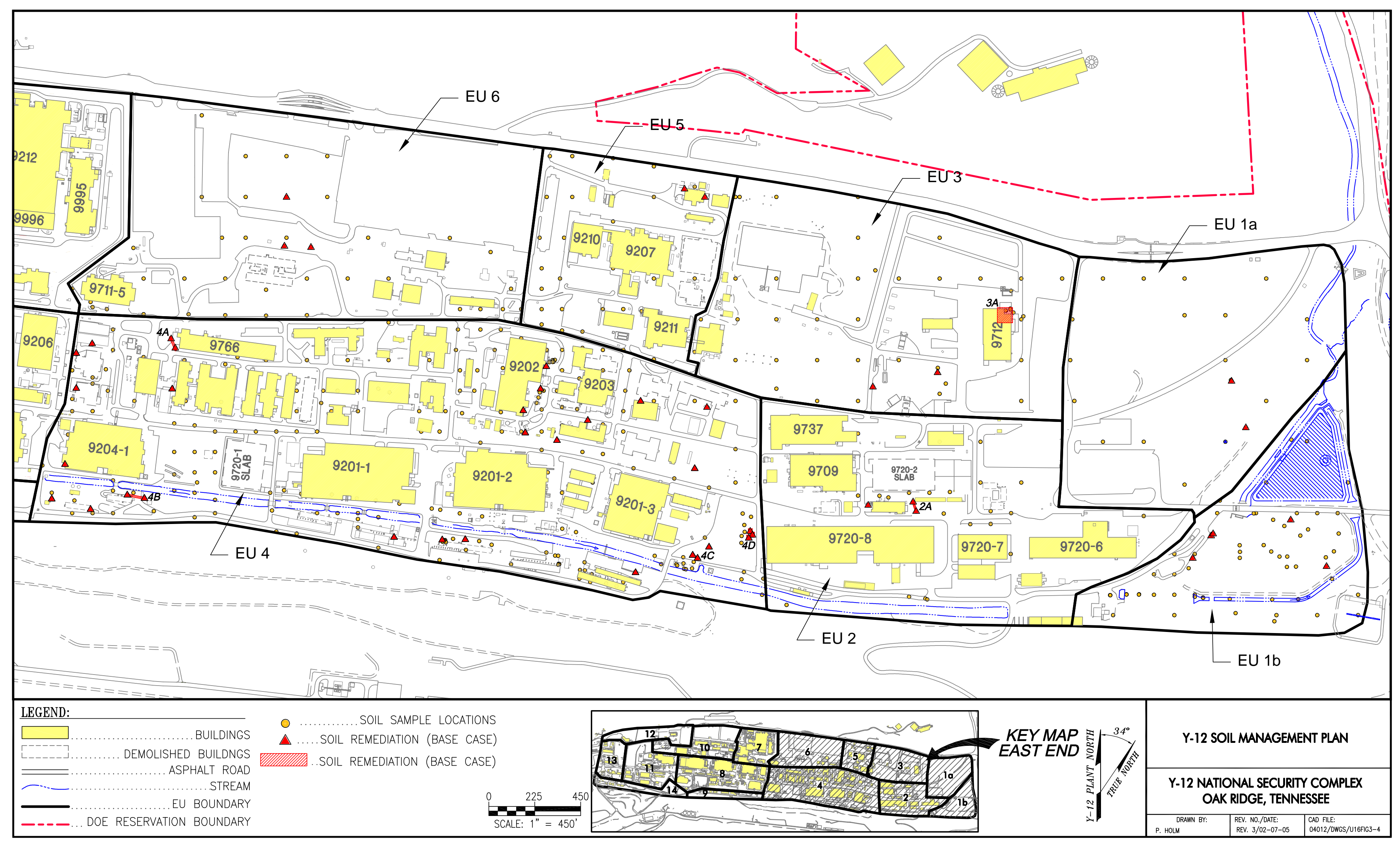

Fig. 3.4. Estimated areas of soil excavation in the eastern Y-12 area under a soil removal alternative, UEFPC Focused Feasibility Study. 


\section{Future Mercury Source Actions, Surface Water, and Groundwater}

An amendment to the ROD for Phase I interim mercury source control actions is also planned to address remediation of Bldg. 81-10 soils and, as feasible, to install hydraulic controls in WEMA to reduce the volume of contaminated groundwater being extracted via building sumps and treated. A final UEFPC decision is also planned to integrate surface water goals for UEFPC and LEFPC. Interim groundwater actions, in addition to the EEVOC Plume removal action, will be taken, if necessary, to further protect off-site receptors. A final decision for groundwater, and other potential remaining environmental liabilities, represents the last planned watershed-scale decision, which will occur after future building decontamination and decommissioning activities. As future actions are completed, amendments to the LUCIP for UEFPC will be completed to incorporate any additional controls prescribed by the remedies.

\subsubsection{Comprehensive Environmental Response, Compensation, and Liability Act Actions in the Bear Creek Watershed}

In addition to RCRA closures at the former S-3 Ponds (S-3 Site), Oil Landfarm, and portions of BCBG discussed in Sect. 3.1.1, a number of CERCLA responses have been completed or are ongoing in the Bear Creek Watershed. The Bear Creek Watershed encompasses that portion of Bear Creek Valley (BCV) from the S-3 Site and extending west to the confluence of Bear Creek with East Fork Poplar Creek near the Highway 95/58 junction. A brief summary of these actions and long-term monitoring and stewardship requirements is provided for informational purposes should soil disturbance activities be planned within this watershed.

CERCLA actions, completed to date (Table 3.4), have addressed principal sources of contaminant releases or reduce the potential for exposure to contaminants for the public or workers. Figure 3.5 illustrates the locations of completed and ongoing actions, taken to date, in the Bear Creek Watershed. An additional completed action (White Wing Scrapyard) is located in the extreme western portion of the watershed. All of the completed and ongoing actions, to date, involve long-term remedial effectiveness monitoring and/or stewardship requirements. These completed and ongoing decisions, to date, also encompass land use and access controls that must be considered in any future soil excavation planning activities involving the affected areas.

Under the Bear Creek Phase I ROD (summarized in Table 3.4), soil excavation, capping, and restoration actions at the Boneyard/Burnyard (BY/BY) were completed in 2003. As water quality data are compiled and evaluated to assess attainment of watershed-scale remediation goals, additional actions under a future watershed-level decision will be identified as necessary. This future decision will also address waste units in BCBG, White Wing Scrapyard, and final remediation goals for both groundwater and the S-3 Site.

\subsubsection{Comprehensive Environmental Response, Compensation, and Liability Act Actions in the Chestnut Ridge Administrative Area}

In the Chestnut Ridge area, three CERCLA actions have been completed to date: Kerr Hollow Quarry (KHQ), Filled Coal Ash Pond (FCAP), and the United Nuclear Corporation (UNC) Site (Fig. 3.2, Table 3.5). Each of these actions includes long-term monitoring and stewardship requirements, including inspection and maintenance of various engineered controls and monitoring networks (e.g., fencing, multilayered caps, erosion controls, etc.). The CERCLA decision for KHQ defers to the RCRA post-closure permit for long-term groundwater monitoring and maintenance of the monitoring network. As noted in Sect. 3.1.1, any changes or modifications to the KHQ monitoring network or survey benchmarks require prior approval from TDEC and a formal modification to the post-closure permit. The UNC Site 
Table 3.4. Summary of completed and ongoing CERCLA response actions in the Bear Creek Watershed

\begin{tabular}{|c|c|c|c|c|}
\hline Site/project & Summary of selected remedy & $\begin{array}{c}\text { Summary of performance } \\
\text { goals }\end{array}$ & $\begin{array}{l}\text { Monitoring/ stewardship } \\
\text { requirements }\end{array}$ & $\begin{array}{l}\text { Reference for } \\
\text { monitoring/stewardship } \\
\text { requirements }\end{array}$ \\
\hline $\begin{array}{l}\text { Spoil Area } 1 \\
\text { and SY-200 } \\
\text { Yard (Bear } \\
\text { Creek OU 2) } \\
\text { Remedial } \\
\text { Action }\end{array}$ & $\begin{array}{l}\text { Physical barriers (fences, gates, and } \\
\text { signs). } \\
\text { Land use controls. } \\
\text { Surveillance and maintenance. }\end{array}$ & $\begin{array}{l}\text { Restrict access and use. } \\
\text { Maintain integrity of surface } \\
\text { cover and site features. }\end{array}$ & $\begin{array}{l}\text { None; surveillance and } \\
\text { maintenance of access } \\
\text { controls and surface cover. }\end{array}$ & $\begin{array}{l}\text { Record of Decision for Bear } \\
\text { Creek Valley OU } 2 \text { (Spoil } \\
\text { Area } 1 \text { and SY-200 Yard), } \\
\text { DOE/OR/02-1435\&D2. }\end{array}$ \\
\hline $\begin{array}{l}\text { S-3 Ponds } \\
\text { Tributary } \\
\text { Interception } \\
\text { (Pathways } 1 \\
\text { and 2) }\end{array}$ & $\begin{array}{l}\text { Install a reactive barrier to collect and } \\
\text { treat (in situ) uranium-contaminated } \\
\text { groundwater. }\end{array}$ & $\begin{array}{l}\text { Reduce flux of uranium in } \\
\text { Bear Creek that is associated } \\
\text { with discharge from shallow } \\
\text { groundwater. }\end{array}$ & $\begin{array}{l}\text { Monitoring, surveillance, } \\
\text { and maintenance } \\
\text { requirements to be } \\
\text { determined under a future } \\
\text { decision for the Bear Creek } \\
\text { Watershed. }\end{array}$ & $\begin{array}{l}\text { Action Memorandum for the } \\
\text { Bear Creek Valley } \\
\text { Interception Trenches for the } \\
\text { S-3 Uranium Plume, Oak } \\
\text { Ridge, Tennessee, } \\
\text { DOE/OR/01-1739\&D1. }\end{array}$ \\
\hline $\begin{array}{l}\text { BCV Phase I } \\
\text { ROD: S-3 Site } \\
\text { Pathway } 3 \\
\text { (ongoing), Oil } \\
\text { Landfarm } \\
\text { (ongoing) area, } \\
\text { and BY/BY } \\
\text { (completed) }\end{array}$ & $\begin{array}{l}\text { S-3 Site: Install a trench at NT-1 for } \\
\text { passive in situ treatment of shallow } \\
\text { groundwater. } \\
\text { BY/BY: Excavate source areas and } \\
\text { contaminated floodplain soils and } \\
\text { sediments; on-site disposal of excavated } \\
\text { materials meeting waste acceptance } \\
\text { criteria at the EMWMF and off-site } \\
\text { disposal of materials exceeding } \\
\text { EMWMF waste acceptance criteria; } \\
\text { install clay cap over uncapped disposal } \\
\text { areas; maintain existing caps; and } \\
\text { implement hydraulic isolation measures, } \\
\text { including reconstruction of NT-3, } \\
\text { elimination of stagnation points, and }\end{array}$ & $\begin{array}{l}\text { Preservation of groundwater } \\
\text { and surface water quality in } \\
\text { Zone } 1 \text { of BCV and attaining } \\
\text { improvements in water } \\
\text { quality in Zones } 2 \text { and } 3 \text { of } \\
\text { BCV. } \\
\text { Numeric performance } \\
\text { standards for uranium and } \\
\text { mercury at NT-3; uranium, } \\
\text { cadmium, and nitrate at } \\
\text { BCK } 12.34 \text {; and } \\
\text { risk/chemical hazards at the } \\
\text { BKC } 9.47 \text { integration point. }\end{array}$ & $\begin{array}{l}\text { Monitoring and } \\
\text { enforcement of use controls } \\
\text { on groundwater and surface } \\
\text { water. Maintenance of } \\
\text { existing and new caps in the } \\
\text { Oil Landfarm and BY/BY } \\
\text { area. Maintain current land } \\
\text { use and access controls. } \\
\text { Future potential land use } \\
\text { controls, as needed, to } \\
\text { achieve land use objectives } \\
\text { of the ROD and attendant } \\
\text { LUCIP. }\end{array}$ & $\begin{array}{l}\text { Record of Decision for the } \\
\text { Phase I Activities in Bear } \\
\text { Creek Valley at the Oak Ridge } \\
\text { Y-12 Plant, Oak Ridge, } \\
\text { Tennessee, DOE/OR/01- } \\
\text { 1750\&D4. }\end{array}$ \\
\hline
\end{tabular}




\begin{tabular}{|c|c|c|c|c|}
\hline Site/project & Summary of selected remedy & $\begin{array}{l}\text { Summary of performance } \\
\text { goals }\end{array}$ & $\begin{array}{l}\text { Monitoring/ stewardship } \\
\text { requirements }\end{array}$ & $\begin{array}{l}\text { Reference for } \\
\text { monitoring/stewardship } \\
\text { requirements }\end{array}$ \\
\hline $\begin{array}{l}\text { BCV Phase I } \\
\text { ROD: S-3 Site } \\
\text { Pathway 3, Oil } \\
\text { Landfarm area, } \\
\text { and BY/BY } \\
\text { (continued) }\end{array}$ & $\begin{array}{l}\text { installation of drains or well points. } \\
\text { Oil Landfarm: Remove waste stored in } \\
\text { the Oil Landfarm Soil Containment Pad } \\
\text { for commercial off-site disposal and } \\
\text { dismantle the structure. } \\
\text { Other: Remove waste stored in the } \\
\text { Disposal Area Remedial Action facility } \\
\text { for off-site commercial disposal, and } \\
\text { dismantle the structure. }\end{array}$ & $\begin{array}{l}\text { Groundwater and surface } \\
\text { water quality goals relative } \\
\text { to surface water AWQCs } \\
\text { and drinking water MCLs. }\end{array}$ & & \\
\hline EMWMF & $\begin{array}{l}\text { Design, construct, operate, and close an } \\
\text { engineered, above-grade disposal cell } \\
\text { and associated support facilities for the } \\
\text { disposal of non-classified and classified } \\
\text { non-liquid wastes (e.g., soil, dried } \\
\text { sludges, debris, and scrap equipment), } \\
\text { including low-level radiological waste, } \\
\text { RCRA waste, TSCA waste, and mixtures } \\
\text { of the above-regulated wastes. }\end{array}$ & $\begin{array}{l}\text { Provide capacity on the } \\
\text { ORR for the permanent, } \\
\text { consolidated disposal of } \\
\text { CERCLA wastes that will be } \\
\text { generated from response } \\
\text { actions at individual sites } \\
\text { and that present } \\
\text { unacceptable risks. }\end{array}$ & $\begin{array}{l}\text { Monitoring groundwater, } \\
\text { surface water, collected } \\
\text { leachate and contact waters, } \\
\text { and air. } \\
\text { Operational inspections and } \\
\text { maintenance, including } \\
\text { leachate collection and } \\
\text { treatment. } \\
\text { Facility closure upon } \\
\text { attaining capacity, including } \\
\text { demolition of support } \\
\text { facilities and disposal in the } \\
\text { EMWMF. } \\
\text { Post-closure monitoring and } \\
\text { indefinite institutional and } \\
\text { access controls, regular } \\
\text { surveillance inspections, } \\
\text { and maintenance. }\end{array}$ & $\begin{array}{l}\text { Record of Decision for the } \\
\text { Disposal of Oak Ridge } \\
\text { Reservation Comprehensive } \\
\text { Environmental Response, } \\
\text { Compensation, and Liability } \\
\text { Act of } 1980 \text { Waste, Oak Ridge, } \\
\text { Tennessee, DOE/OR/01- } \\
\text { 1791\&D3. }\end{array}$ \\
\hline
\end{tabular}




\begin{tabular}{|c|c|c|c|c|}
\hline Site/project & Summary of selected remedy & $\begin{array}{c}\text { Summary of performance } \\
\text { goals }\end{array}$ & $\begin{array}{l}\text { Monitoring/ stewardship } \\
\text { requirements }\end{array}$ & $\begin{array}{c}\text { Reference for } \\
\text { monitoring/stewardship } \\
\text { requirements }\end{array}$ \\
\hline $\begin{array}{l}\text { White Wing } \\
\text { Scrapyard } \\
\text { Interim ROD } \\
\text { (Waste Area }_{\text {Grouping } 11)^{b}}\end{array}$ & $\begin{array}{l}\text { Removal of radiologically contaminated } \\
\text { scrap and debris and disposal at WAG } 6 \\
\text { at ORNL; revegetation of disturbed } \\
\text { areas. }\end{array}$ & $\begin{array}{l}\text { Reduce environmental } \\
\text { degradation. Reduce } \\
\text { physical safety concerns and } \\
\text { site surveillance and } \\
\text { maintenance costs. }\end{array}$ & $\begin{array}{l}\text { No specified stewardship } \\
\text { requirements in the interim } \\
\text { ROD. Site is fenced and } \\
\text { posted to provide access } \\
\text { control and inspected as a } \\
\text { BMP. }\end{array}$ & $\begin{array}{l}\text { Interim Record of Decision for } \\
\text { the Oak Ridge National } \\
\text { Laboratory Waste Area } \\
\text { Grouping } 11 \text { Surface Debris, } \\
\text { Oak Ridge, Tennessee, } \\
\text { DOE/OR-1055\&D4. }\end{array}$ \\
\hline
\end{tabular}

Note: Report is currently conducted as baseline monitoring pending modifications to the remedial system. Final monitoring requirements will be developed following implementation of the remedial system modification and presented in the D2 revision of the Removal Action Report.

${ }^{a}$ Monitoring specified in the D1 revision of the Removal Action.

${ }^{b}$ Currently included as a miscellaneous action under CERCLA remediation effectiveness evaluation.

AWQC = Ambient Water Quality Criteria.

$\mathrm{BCV}=$ Bear Creek Valley.

$\mathrm{BY} / \mathrm{BY}=$ Boneyard/Burnyard.

CERCLA = Comprehensive Environmental Response, Compensation, and Liability Act.

EMWMF = Environmental Management Waste Management Facility.

LUCIP $=$ Land Use Control Implementation Plan.

$\mathrm{MCL}=$ maximum contaminant level.

NT $=$ North Tributary.

ORNL = Oak Ridge National Laboratory.

ORR $=$ Oak Ridge Reservation

$\mathrm{OU}=$ operable unit.

RCRA = Resource Conservation and Recovery Act.

$\mathrm{ROD}=$ record of decision

TSCA $=$ Toxic Substances Control Act. 


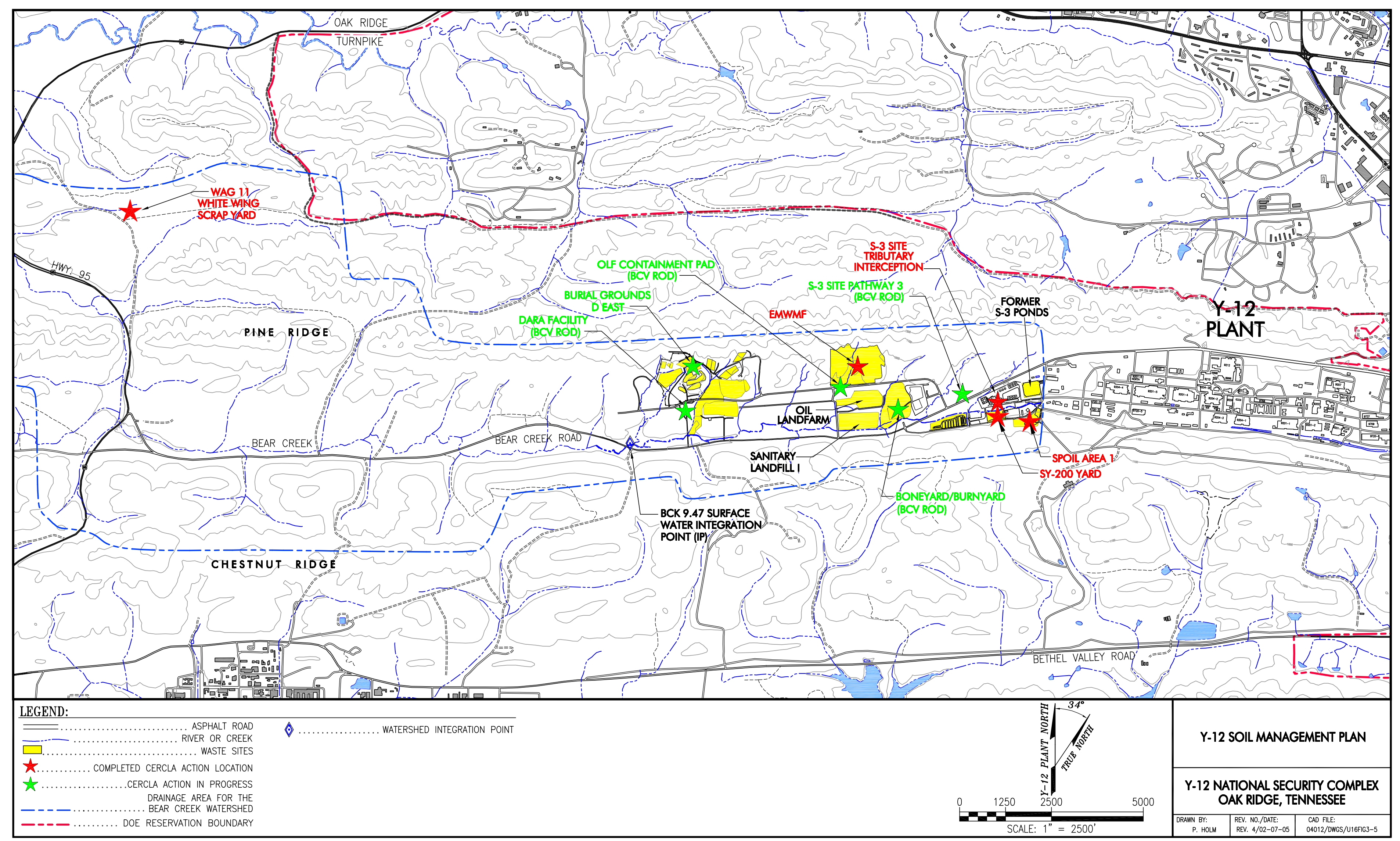

Fig. 3.5. Locations of completed and ongoing CERCLA response actions in the Bear Creek Watershed. 
Table 3.5. Summary of completed and ongoing CERCLA response actions in the Chestnut Ridge administrative area

\begin{tabular}{|c|c|c|c|c|}
\hline Site/project & Summary of selected remedy & Summary of performance goals & $\begin{array}{c}\text { Monitoring/stewardship } \\
\text { requirements }\end{array}$ & $\begin{array}{c}\text { Reference for } \\
\text { monitoring/stewardship } \\
\text { requirements } \\
\end{array}$ \\
\hline KHQ & $\begin{array}{l}\text { RCRA closure. Removal of visible } \\
\text { debris and solid waste from the } \\
\text { quarry. Contaminated sediment and } \\
\text { non-visible debris left in place. } \\
\text { Physical access controls and site } \\
\text { postings. }\end{array}$ & $\begin{array}{l}\text { Prevent the physical exposure to } \\
\text { contaminants and mitigate the } \\
\text { migration of contaminants to } \\
\text { groundwater or surface water } \\
\text { runoff. RCRA closure activities } \\
\text { were deemed protective of human } \\
\text { health and the environment; } \\
\text { therefore, no further action was } \\
\text { required under the CERCLA } \\
\text { ROD. }\end{array}$ & $\begin{array}{l}\text { Groundwater detection } \\
\text { monitoring under the } \\
\text { RCRA post-closure permit. } \\
\text { Maintenance of the } \\
\text { monitoring network and } \\
\text { access controls (e.g., } \\
\text { fencing and warning signs). }\end{array}$ & $\begin{array}{l}\text { Record of Decision for } \\
\text { Kerr Hollow Quarry at } \\
\text { the Oak Ridge Y-12 } \\
\text { Plant, Oak Ridge, } \\
\text { Tennessee, } \\
\text { DOE/OR/02-1398\&D2. }\end{array}$ \\
\hline FCAP & $\begin{array}{l}\text { Dam slope stabilization, runoff } \\
\text { controls and grading, artificial wetland } \\
\text { construction, and site postings. }\end{array}$ & $\begin{array}{l}\text { Reduce the risk to human and } \\
\text { ecological receptors by: } \\
\text { (1) improving the containment of } \\
\text { coal ash, (2) reducing contaminant } \\
\text { migration into Upper McCoy } \\
\text { Branch with a passive treatment } \\
\text { system (wetland), and (3) } \\
\text { restricting human access to the } \\
\text { contamination by implementing } \\
\text { institutional controls. }\end{array}$ & $\begin{array}{l}\text { Inspection of the dam, } \\
\text { spillway channel, adjacent } \\
\text { slopes, settling basin, and } \\
\text { wetland area. Surface water } \\
\text { monitoring above and } \\
\text { below the passive treatment } \\
\text { wetland. }\end{array}$ & $\begin{array}{l}\text { Record of Decision for } \\
\text { Chestnut Ridge Operable } \\
\text { Unit } 2 \text { (Filled Coal Ash } \\
\text { Pond and Vicinity), Oak } \\
\text { Ridge, Tennessee, } \\
\text { DOE/OR/02-1410\&D3. }\end{array}$ \\
\hline UNC Site & $\begin{array}{l}\text { Engineered cap, drainage controls, and } \\
\text { site postings. }\end{array}$ & $\begin{array}{l}\text { Ensure that mobile contaminants } \\
\text { in the UNC waste (nitrate and } \\
\text { in } \mathrm{Sr} \text {, are not leached to } \\
\text { groundwater at a rate that would } \\
\text { result in concentrations above safe } \\
\text { drinking water standards. }\end{array}$ & $\begin{array}{l}\text { Groundwater monitoring. } \\
\text { Inspection and maintenance } \\
\text { of the engineered cap, } \\
\text { monitoring network, and } \\
\text { site postings. }\end{array}$ & $\begin{array}{l}\text { Record of Decision for } \\
\text { the United Nuclear } \\
\text { Corporation Disposal } \\
\text { Site, Y-12 Plant, Oak } \\
\text { Ridge, Tennessee, } \\
\text { June } 1991 .\end{array}$ \\
\hline
\end{tabular}

CERCLA = Comprehensive Environmental Response, Compensation, and Liability Act.

FCAP $=$ Filled Coal Ash Pond

$\mathrm{KHQ}=$ Kerr Hollow Quarry.

$\mathrm{OU}=$ operable unit.

RCRA = Resource Conservation and Recovery Act.

$\mathrm{ROD}=$ record of decision

$\mathrm{UNC}=$ United Nuclear Corporation. 
action included the installation of an engineered multi-layer cap, and FCAP RAs included the installation of a vegetation cover and wetlands. Both actions include the maintenance of covers and drainage controls and the performance of assessment monitoring.

Because of the hydrologic characteristics of the Chestnut Ridge area and comparatively limited nature and extent of contaminants, a watershed-scale decision involving numeric performance standards at a single integration point is not currently planned. A future environmental remedial decision under CERCLA is planned to address soils and to reduce the potential for future releases to surface water at remaining legacy sites not addressed to date (e.g., Rogers Quarry and Chestnut Ridge Security Pits). This future decision will also include a groundwater component.

\subsection{SOLID WASTE MANAGEMENT UNITS}

More than 200 SWMU sites pursuant to Sect. 3004u of RCRA have been identified within Y-12, in the Bear Creek Watershed, and the Chestnut Ridge area. These SWMUs represent known or potential sources of contamination to the environment as a result of past waste management practices. The SWMUs are tracked and governed under the RCRA HSWA portion of the RCRA Operating Permit for ORR.

A number of the SWMUs have been specifically investigated under either historical RCRA programs or the CERCLA FFA and have progressed into RA phases or have had NFA/investigation decisions rendered. Corrective action for historical SWMUs under the HSWA permit and RAs for CERCLA AOCs under the FFA have been, for the most part, combined into a single program under CERCLA, however, language found within the permit allows the state to require cleanup to be conducted separately under the RCRA permit if warranted. These units are tracked in an information database commonly referred to as the RA Information Management System (RAIMS). RAs at SWMUs taken to date are delineated in Sect. 3.1. Legacy soil contamination within SWMUs, based on available data, is addressed in Sect. 3.3. Other SWMUs identified within RAIMS represent non-point sources or AOCs (e.g., groundwater plumes for which RAs are ongoing or planned under future decisions). Planning for soil disturbances should evaluate whether the activity will take place within a SWMU and whether any regulatory or land use controls/restrictions may be in force in accordance with the HSWA permit.

Complete regulatory status information for individual SWMUs may be found in RAIMS. A current listing and summary of the regulatory status of known SWMUs is contained in Appendix B. Plates 1, 1A, 1B, and 1C illustrate the locations of SWMUs indicated in Appendix B.

\subsubsection{Upper East Fork Poplar Creek Watershed (the Y-12 National Security Complex)}

A total of 165 SWMUs have been identified and cataloged within the UEFPC Watershed. These units include a wide range of unit types, including a substantial number of comparatively small former UST locations and loading dock areas to broad classifications of contaminated media (e.g., soils and groundwater throughout the watershed). Actions taken, to date, at SWMUs within the UEFPC Watershed are described in Sects. 3.1.1 and 3.1.2.

\subsubsection{Bear Creek Watershed}

A total of 45 SWMUs have been identified in the Bear Creek Watershed and entered into the RAIMS database as of 2004. The majority of SWMU designations within this watershed encompass relatively large areas, including former waste management units such as the BCBG, as well as broad classifications of contaminated media (e.g., Bear Creek floodplain soils). Actions taken, to date, at SWMUs within the Bear Creek Watershed are described in Sects. 3.1.1 and 3.1.3. 


\subsubsection{Chestnut Ridge Administrative Area}

A total of 18 SWMUs have been designated in the Chestnut Ridge administrative area and entered into the RAIMS database as of 2004. As with the Bear Creek Watershed, designated SWMUs in the Chestnut Ridge administrative area primarily encompass former waste management areas (e.g., Chestnut Ridge Security Pits), along with broad classifications of contaminated media (e.g., contaminated soil and groundwater). Actions taken, to date, at SWMUs within the Chestnut Ridge administrative area are described in Sects. 3.1.1 and 3.1.4.

\subsection{SUMMARY OF ENVIRONMENTAL CONTAMINATION IN SOIL}

This section summarizes information obtained, to date, on legacy environmental contamination within the UEFPC Watershed associated with source areas outlined in Sect. 3.2. Brief overviews of environmental contamination in the adjacent Bear Creek Watershed and the Chestnut Ridge administrative area are also provided for completeness. Detailed presentations of environmental legacy contamination in the UEFPC Watershed maybe found in the CERCLA RI report (DOE 1998). Additionally, comprehensive information for the Bear Creek Watershed may be found in the RI report for this watershed (DOE 1997). A comprehensive RI report has not been prepared for the Chestnut Ridge Hydrogeologic Regime and very little data related to soil contamination levels have been obtained; however, current information on waste management units and environmental issues is published in the ORR Annual Site Environmental Report and in the annual CERCLA RER. Additionally, ongoing compliance program and CERCLA monitoring data and detailed historical analytical data are compiled in the Oak Ridge Environmental Information System.

\subsubsection{Upper East Fork Poplar Creek Watershed}

\subsubsection{Soil source areas}

Soil contamination source areas include current and former operational and materials storage facilities (e.g., docks, container storage areas, material staging yards, etc.), waste management units having wastes in place, and miscellaneous AOCs. The principal contaminants associated with these sources include radionuclides (uranium and daughter products) and mercury. Contaminants other than uranium and mercury are known to occur in conjunction with miscellaneous source areas, many of which are SWMUs that are no longer operational [e.g., organics at the former Salvage Yard Drum Deheader Facility and PCBs within the former Z-Oil distribution facility]. Some miscellaneous areas of soil contamination were created through redistribution/dispersion of contaminated material during various historical construction, grading, or other industrial activities throughout Y-12. In many of these miscellaneous locations, uranium and mercury are co-located with these other classes of contaminants.

Available information regarding associated environmental legacy contamination at contaminated soil source areas, in particular mercury use areas, may be found in RAIMS (Sect. 3.2) and the UEFPC RI report (DOE 1998). As described in Sect. 3.1, former mercury source areas (Fig. 3.6) are being addressed

under the UEFPC Phase I ROD. Other contaminated soil areas are to be addressed through the future soils ROD. 


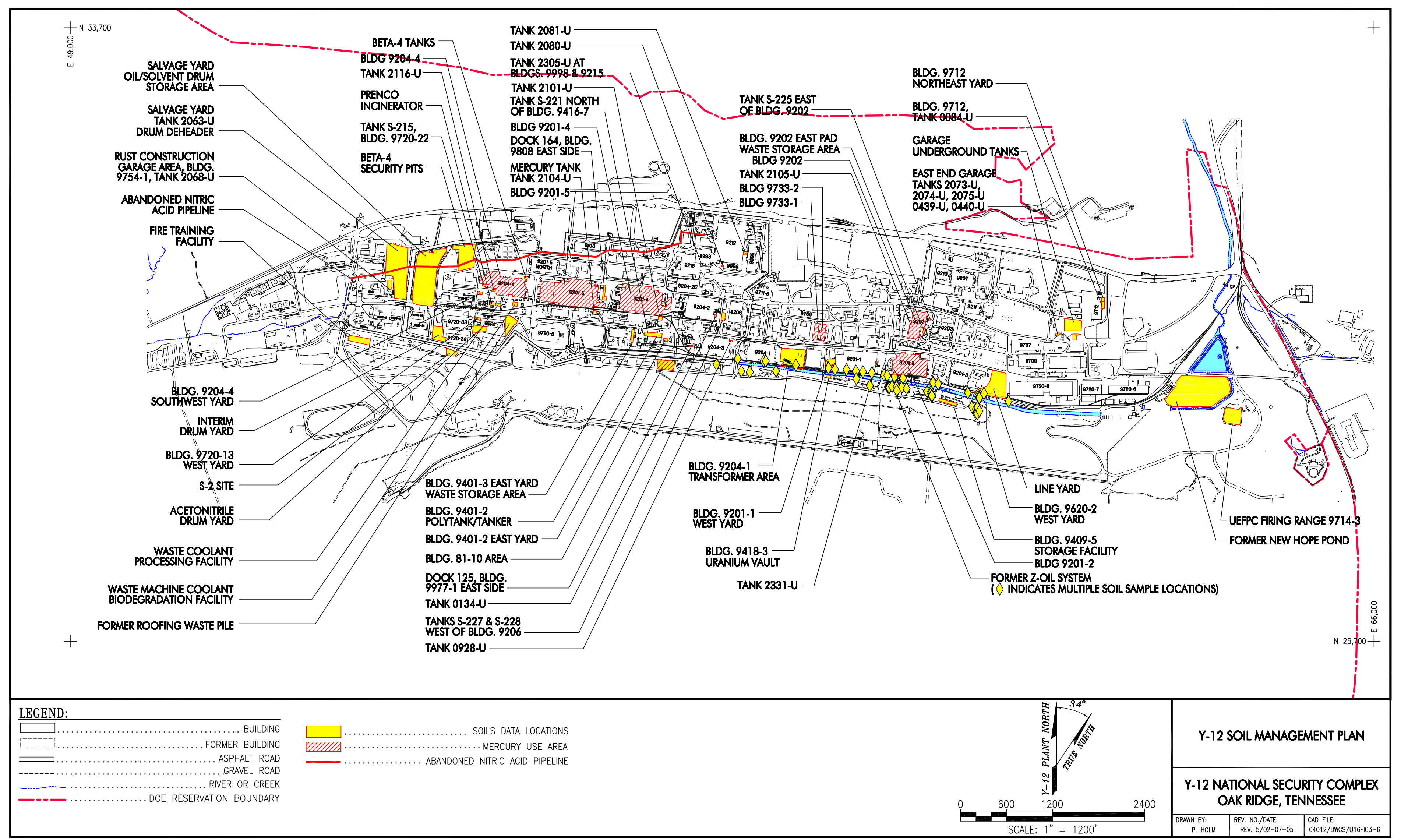




\subsubsection{Soil contamination occurrence and distribution}

Available soil characterization data are derived from numerous historical site-specific investigations associated with various SWMUs and other source areas within Y-12 (Fig. 3.6). In addition, the Outdoor Radiological and Chemical Surface Scoping Survey, conducted in the mid-1980's by the Oak Ridge National Laboratory, included sampling of surface soil (0 to 6 in.) across the facility using a high-density grid sampling approach (MMES 1989). The majority of the grid samples were analyzed for gamma activity, mercury, and 238U. Minority subsets of samples were analyzed for other selected radiological constituents and PCBs. These data have some uncertainty due to their age, but remain a valuable resource for characterizing the potential for encountering certain contaminants. All available historical data were compiled and presented in the UEFPC Watershed RI (DOE 1998).

Concentrations of mercury in surface soil are greatest in the western portion of Y-12, with historical concentrations as high as 7700 parts per million (ppm) within WEMA (Fig. 3.7). Concentrations in excess of $100 \mathrm{ppm}$ in surface soil also occur at Bldg. 9201-2. As evident in Fig. 3.7, mercury contamination in soil has been distributed beyond the immediate vicinity of the mercury use areas through runoff and erosion, as well as through industrial activities such as construction, grading work, and storage of contaminated equipment outdoors. Mercury data for subsurface soil are sporadic and associated primarily with historical investigations at SWMUs. One former investigation at Bldg. 81-10 showed mercury contamination at concentrations as high as $1000 \mathrm{ppm}$ in soil to depths of $12 \mathrm{ft}$ (MMES 1984). In addition to mercury contamination of soil, mercury within the Y-12 storm sewer system and UEFPC stream sediment and bank soils has been identified.

The most comprehensive available data for uranium contamination of surface soil are for ${ }^{238} \mathrm{U}$, which was released through historical uranium-processing operations (Fig. 3.8). Analytical results for ${ }^{238} \mathrm{U}$ from the Outdoor Radiological and Chemical Scoping Survey range from 0.5 to 18,000 (pCi)/g in the eastern end of the characterization area, from 0.24 to $65,000 \mathrm{pCi} / \mathrm{g}$ in the middle portion of the characterization area, and from 0.17 to $109,000 \mathrm{pCi} / \mathrm{g}$ in the western end of the characterization area (DOE 1998). As with mercury, uranium data for subsurface soil is sporadic and associated primarily with historical investigations at SWMUs.

PCBs represent another class of contaminants of particular interest at Y-12 due to their common applications in electrical equipment and other historically used materials (e.g., paint). Figure 3.9 presents available surface soil data for total PCBs within Y-12 at the time of UEFPC RI Report preparation.

Principal soil source areas at Y-12 that have contaminated wastes in place or where residual contaminants other than mercury or uranium have been documented in soil include (Fig. 3.6):

- $\quad$ Fire Training Facility (VOCs and metals),

- Salvage Yard [metals, VOCs, semivolatile organic compounds (SVOCs), and PCBs],

- $\quad$ Rust Construction Garage Area (metals and VOCs),

- Waste Coolant Processing Facility (WCPF) (metals, inorganics, VOCs, and SVOCs),

- Former S-2 Site (nitrate-bearing sludges, SVOCs, radiological constituents, and metals),

- Beta-4 Security Pits (metallic wastes in place),

- Coal Pile Trench (uranium wastes in place),

- Interim Drum Yard (metals, PCBs, VOCs, SVOCs, pesticides, and radiological constituents),

- Tank 0134-U (petroleum compounds),

- Tank 2331-U (metals and petroleum compounds), 


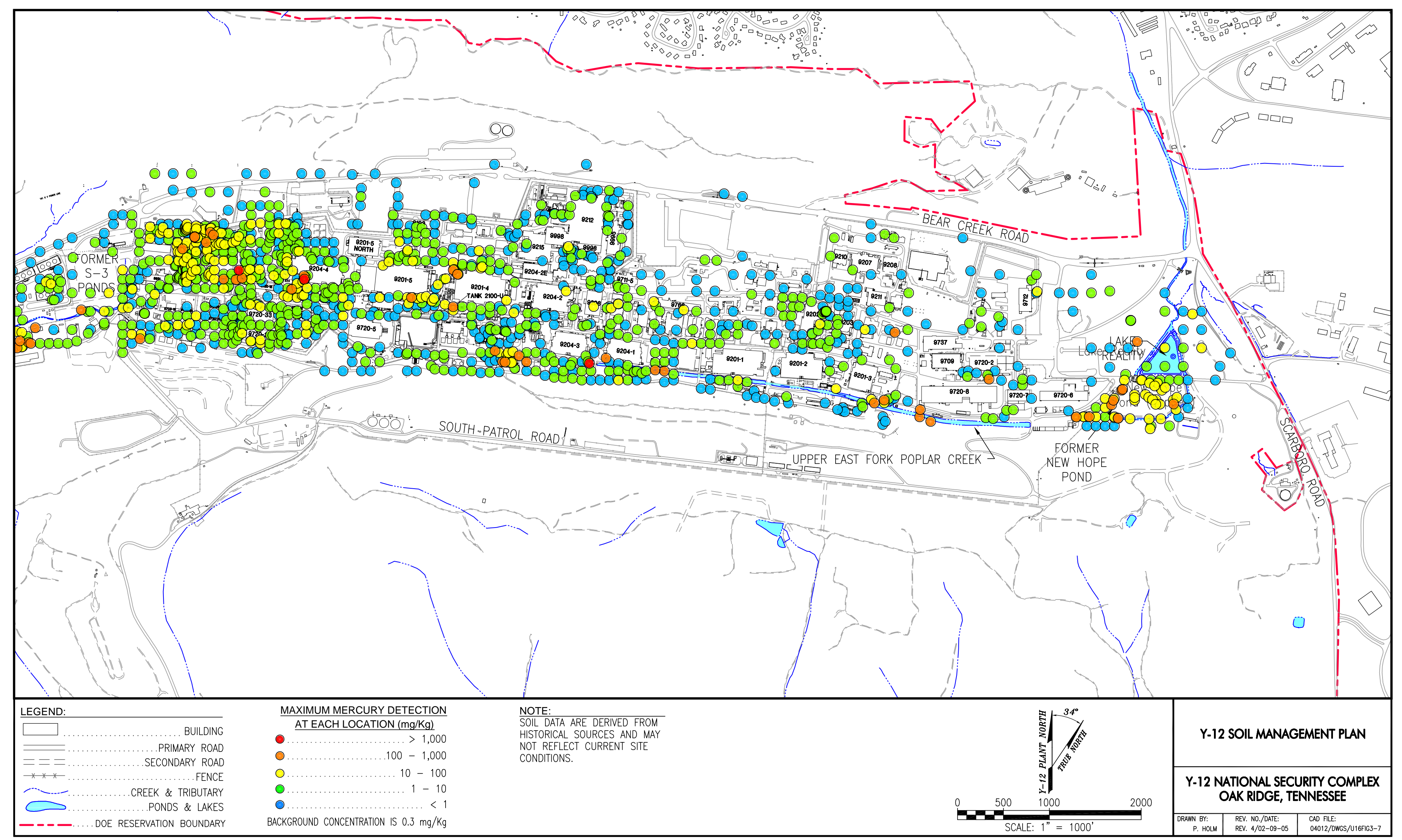

Fig. 3.7. Distribution of mercury in surface soil at $Y-12$. 


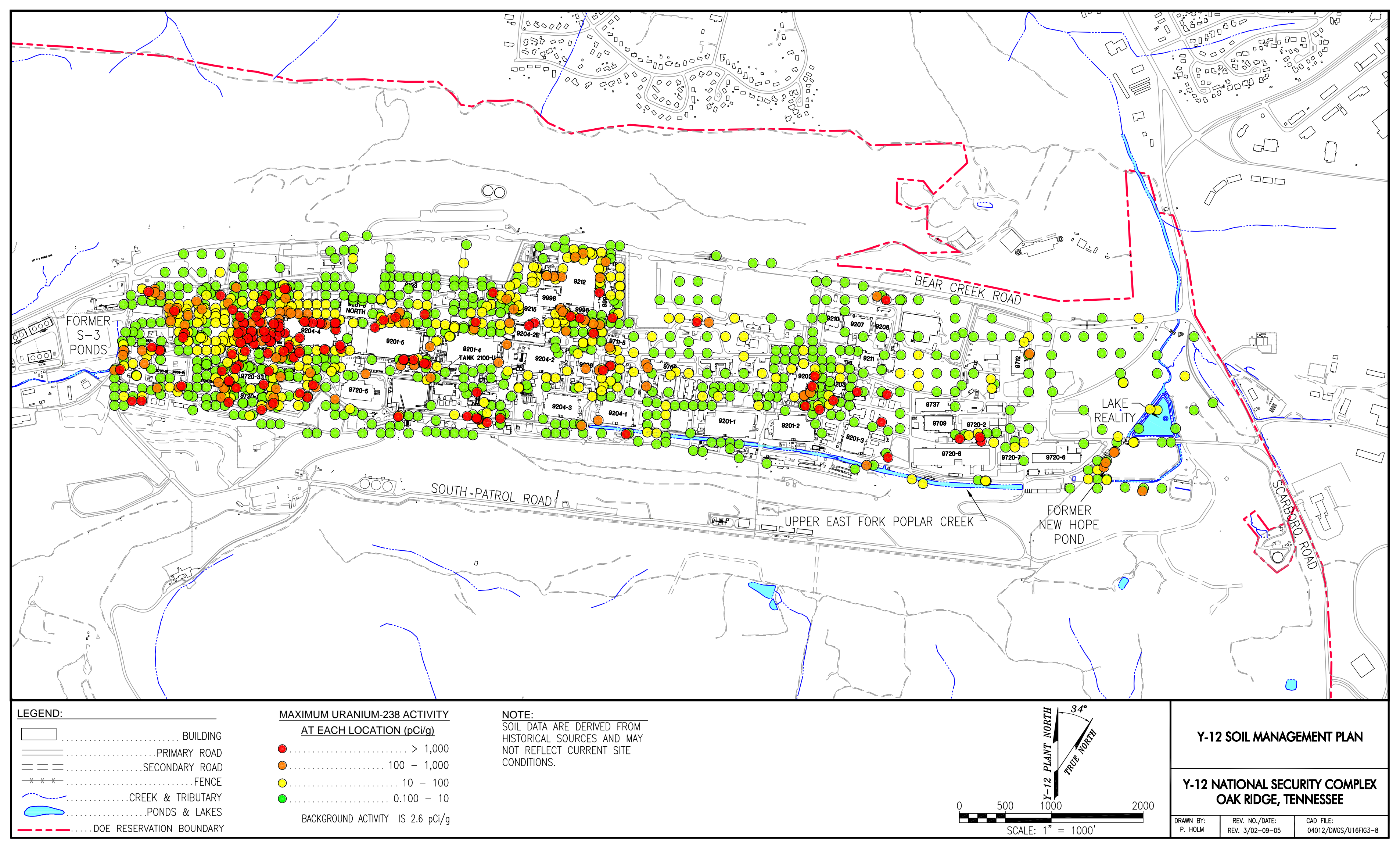




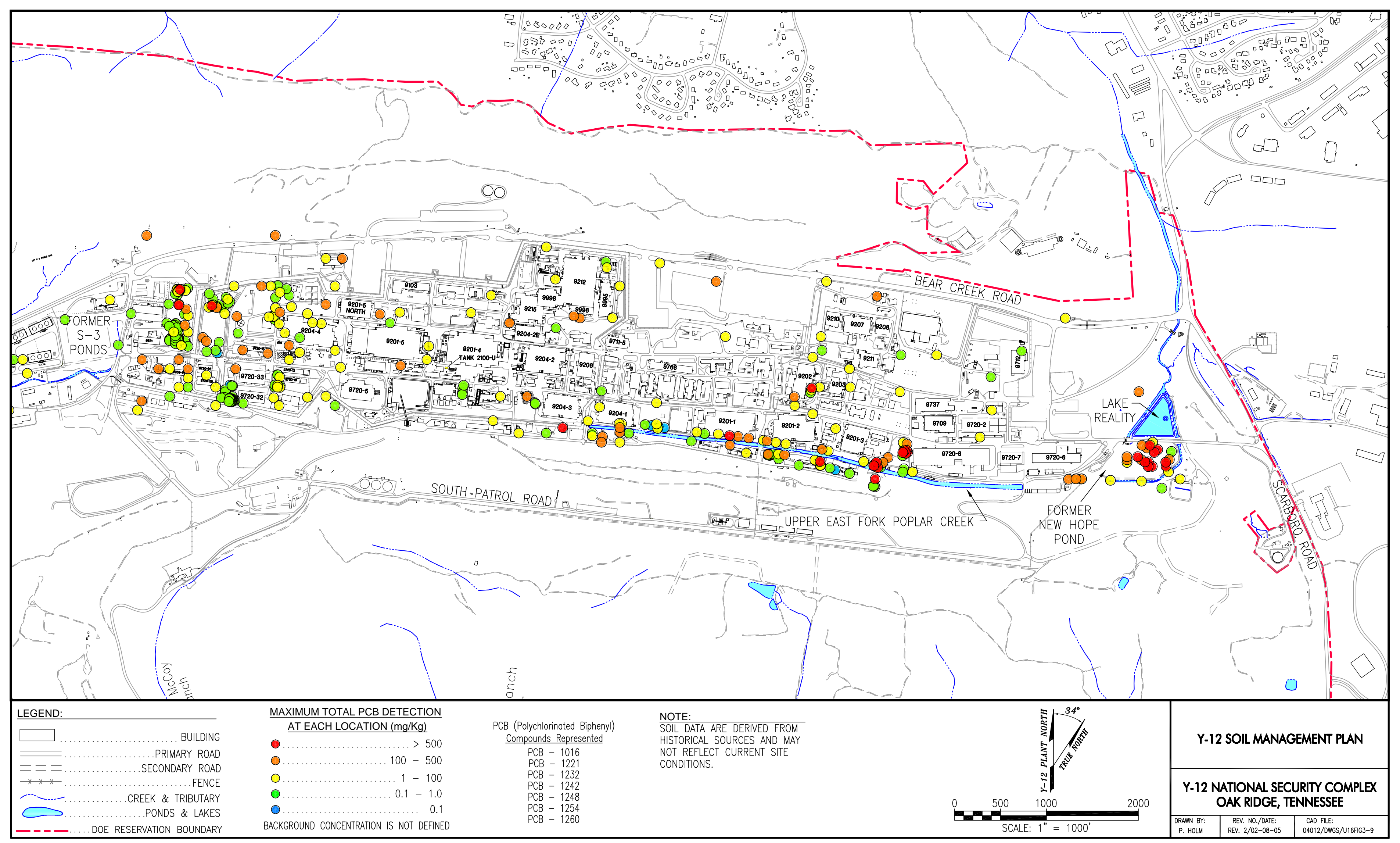


- New Hope Pond (sediments in place, PCBs, and metals including mercury and uranium),

- Former Oil Skimmer Basin (sediments in place and radiological constituents),

- $\quad$ Former Z-Oil distribution system (PCBs),

- Building 9409-5 Storage Area (metals, VOCs, and radiological constituents),

- $\quad$ East End Fuel Station (petroleum compounds, PCBs, and metals),

- $\quad$ East End Pistol Range (lead below removal action criteria), and

- $\quad$ 9418-3 Uranium Vault (uranium oxide wastes in place).

Other soil contaminant source areas have been characterized within Y-12; these sites typically have fewer contaminants, lesser concentrations, and/or more sporadic occurrence and distribution. These additional sites are fully discussed and categorized in the UEFPC RI Report (DOE 1998).

Where chemical specific data were available, risks and chemical hazards to various hypothetical receptors were evaluated in the UEFPC RI. The risk assessment formed the basis for cleanup goals and for delineating areas requiring excavation under a potential soil removal alternative. The most applicable receptor evaluated with respect to planning for potential soil disturbances was the industrial worker scenario. Figure 3.10 illustrates the risks and chemical hazards associated with a hypothetical industrial worker scenario on a sample point-by-sample point basis within the UEFPC Watershed. It is noted that the industrial worker scenario is more conservative in terms of exposure frequency, duration, and pathways than a construction worker scenario. The risk characterization is caveated in that it represents baseline conditions for data at the time of sample collection (some of which dates to the mid-1980s). The assessment also addresses unprotected receptors and does not consider potential IH or RADCON (e.g., engineered controls or PPE) that may be applied (e.g., respirators, protective clothing, etc.). The risks presented also do not reflect changes in the Y-12 physical plant over time; risk reductions achieved through remedial responses; or attenuation of soil contaminants through chemical/biological degradation, radiological decay, or erosional processes.

In addition to the specific investigations noted above, data from various surface radiological surveys, including a comprehensive walkover survey conducted in 1998 and the Outdoor Radiological and Chemical Scoping Survey, were compiled as a Y-12 Site Radiological Characterization Summary in June 2003 (Fig. 3.11). The Radiological Characterization Summary focused on the UEFPC Watershed but also includes portions of the Bear Creek Watershed and the Chestnut Ridge area. Although specific activity concentration values for radiological activity are limited only to historical sampling points, the compilation provides a useful planning reference for evaluating locations where potential outdoor contamination may be encountered and identified areas with fixed contamination. Appendix D contains results of the 1998 walkover survey for 61 potential radiological contamination areas identified from operational information and the FFA.

\subsubsection{Bear Creek Watershed}

\subsubsection{Soil source areas}

As noted in Sect. 3.3.1, a total of 45 contaminant source areas have been identified in the Bear Creek Watershed, which are tracked in RAIMS. The principal source areas within the watershed are closed legacy waste management units associated with historical operations at Y-12. Wastes, contaminated residues, and/or contaminated soil remain in place within all of the legacy waste management units. Wastes and contaminants within these units are varied and include metallic debris and metals-contaminated materials, waste oils, solvents, PCBs, and radiologically contaminated materials. Source removal was completed in 2003 for a large portion of the BY/BY to reduce uranium flux to surface water and groundwater; however, some contaminated residual materials were left in place. Multilayer 


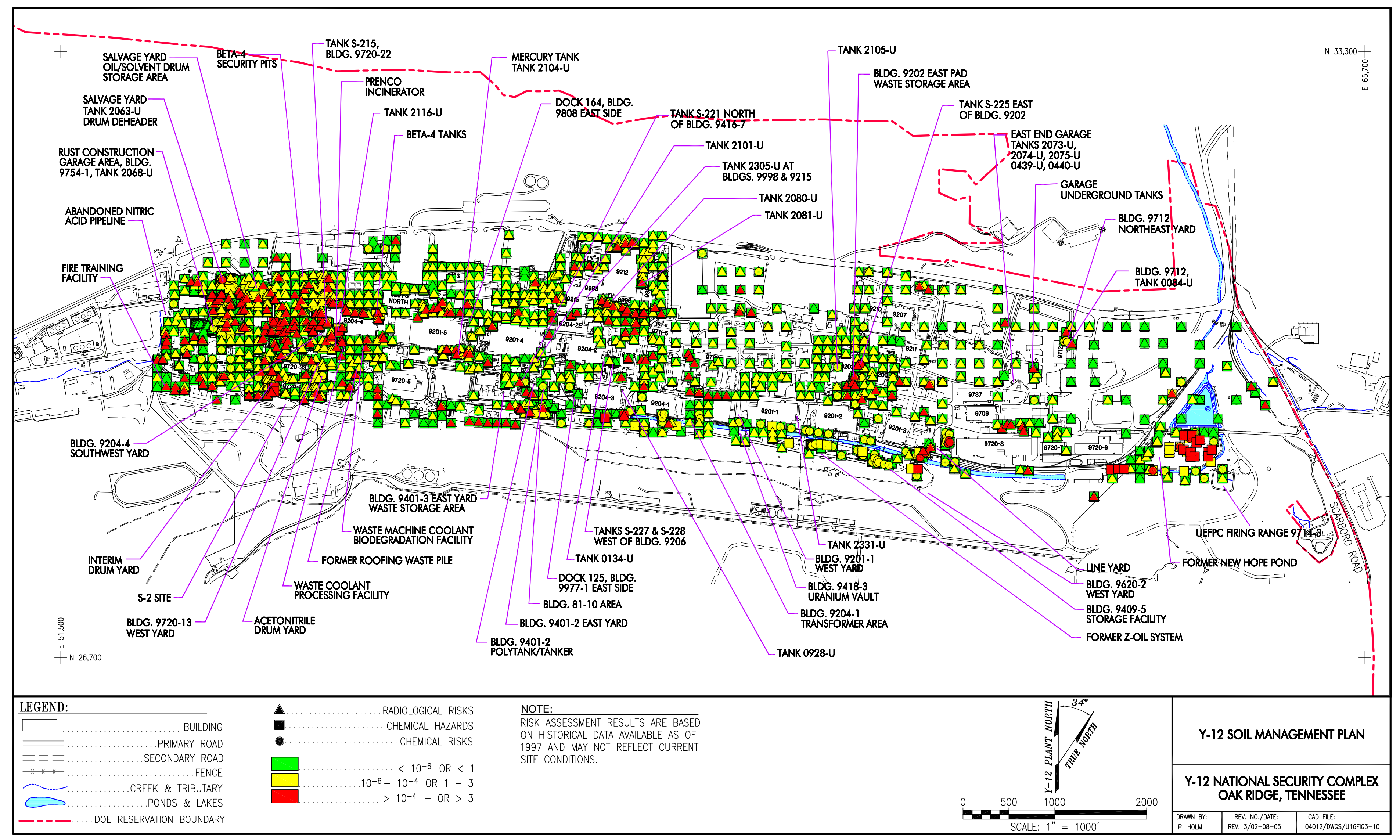




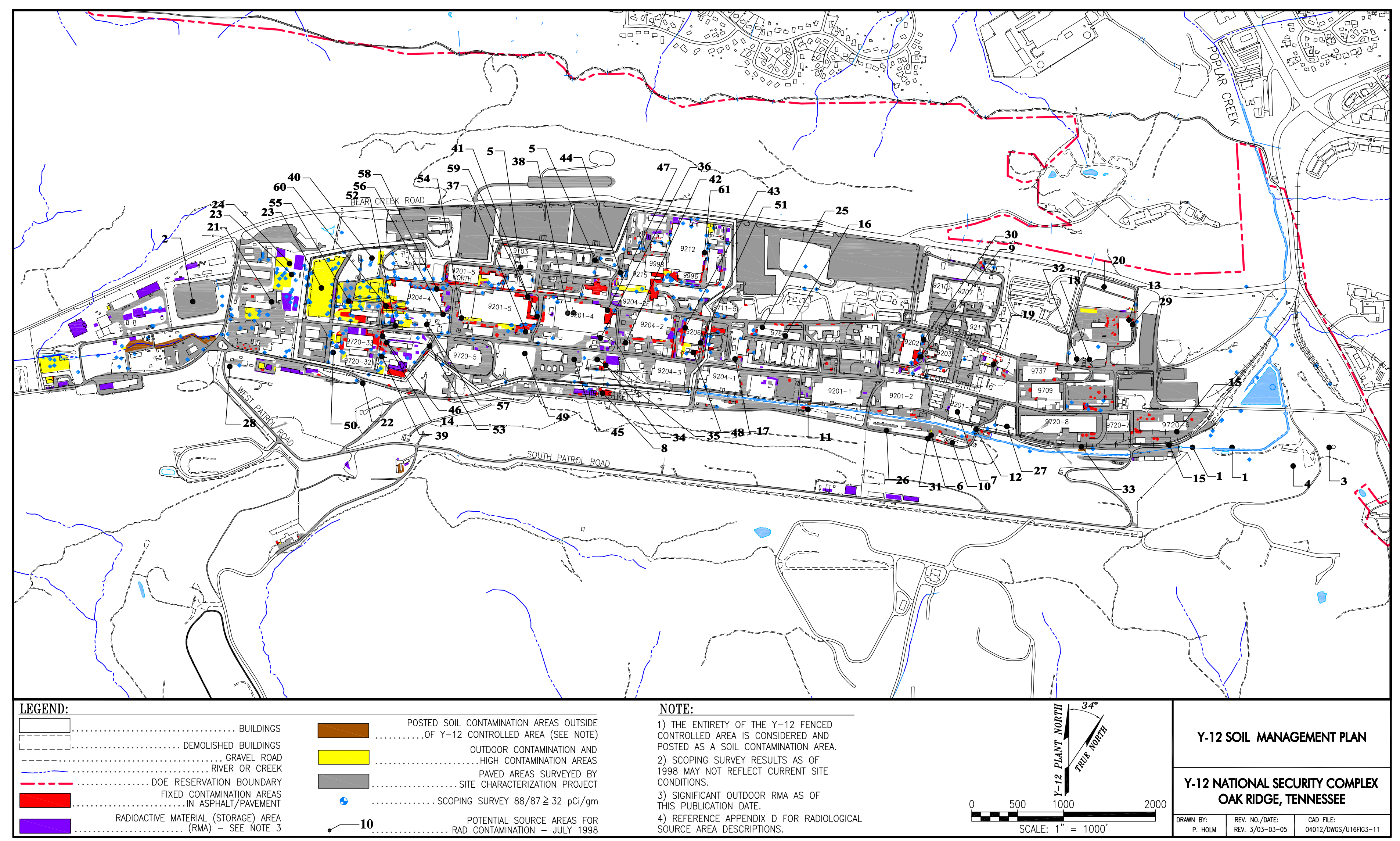

Fig. 3.11. Y-12 radiological characterization summary - UEFPC Watershed and Chestnut Ridge administrative area. 
engineered caps have been installed at the S-3 Site, Oil Landfarm, and BCBG as part of RCRA closures, and these units also have ongoing maintenance requirements under RCRA post-closure permits. The BY/BY was, in part, capped with a clay cover as part of CERCLA RAs.

Active waste management facilities associated with facility operations (West End Treatment Facilities) and CERCLA remediation activities [EMWMF and Disposal Area Remedial Action (DARA) treatment facility within the $\mathrm{BCBG}$ ] also dominate the land use within the watershed. Table 3.6 describes the principal legacy waste management sites and soil source areas within the Bear Creek regime; locations are illustrated on Fig. 3.5. Discussions of completed, ongoing, and planned environmental response actions are presented in Sects. 3.1.1 and 3.1.3.

\subsubsection{Soil contamination occurrence and distribution}

Wastes, contaminated residues, and contaminated soil remain in place within all of the legacy waste management units in the Bear Creek Watershed. Wastes and contaminants within these units are varied and include metallic debris and metals-contaminated materials, waste oils, solvents, PCBs, and radiologically contaminated materials. Source removal was recently completed for a large portion of the BY/BY to reduce uranium flux to surface water and groundwater; however, some contaminated residual materials remain in place. Historical soil characterization within the watershed is somewhat spotty and targeted to specific source areas, including the BCBG, Oil Landfarm, BY/BY, and Sanitary Landfill I vicinities. Historical soil characterization to depths greater than $8 \mathrm{ft}$ has been conducted within these four source areas. As part of the Bear Creek Watershed RI (DOE 1997), walkover surveys (pancake and sodium iodide probes) were conducted at BCBG and BY/BY, and a surface electromagnetic (EM-31) geophysical survey was performed at BY/BY. In addition, Bear Creek floodplain soil and sediment were characterized as part of CERCLA investigations in the watershed.

Soil contaminants within the source areas generally reflect the types of wastes disposed at each unit. Uranium (total and isotopic) represents the most pervasive COC in soil within source areas in the Bear Creek Watershed for an industrial worker receptor scenario, with the exception of Sanitary Landfill I and the Oil Landfarm. Beryllium and thorium isotopes were also identified as COCs in the several of the individual BCBG units, as well as at the former S-3 Ponds. Organics including PCBs, tetrachloroethene, and trichloroethene were also identified as COCs in the Burial Grounds A-North and A-South. Other notable COCs include various radiological contaminants other than uranium at the former S-3 Ponds and semivolatile organics at the former BY/BY. Full discussion of the results for each source area may be found in the Bear Creek RI Report (DOE 1997). Figure 3.12 presents a summary of risks to hypothetical industrial worker and maintenance worker receptors for source areas evaluated in the RI. The risk distribution information is caveated in that the risk assessment evaluated unprotected receptors and does not reflect administrative and engineered controls or PPE that would typically be required by IH or RADCON procedures for workers operating in contaminated areas. The risk assessment results also reflect conditions at the time of the Bear Creek Watershed RI (1995) and do not account for physical changes in the watershed since that time.

Sediment and soil in the Bear Creek floodplain represent receptor media for contaminants that have migrated from various source areas into the Bear Creek tributary system through erosion and depositional processes. Key contaminants observed in sediment and floodplain soil include cadmium, mercury, lithium, uranium, $\mathrm{PCBs}$, and semivolatile organics primarily polycyclic aromatic hydrocarbons. Figures 3.13 through 3.15 illustrate the occurrence and distribution of cadmium, ${ }^{238} \mathrm{U}$, and total PCBs, respectively, in floodplain soil and sediment. However, concentrations of these contaminants were low enough so that there were no identified COCs with risks greater than $10^{-6}$ or chemical hazards $>0.1$ under the hypothetical industrial worker or maintenance worker exposure scenarios. 
Table 3.6. Legacy waste management units in the Bear Creek Hydrogeologic Regime

\begin{tabular}{|c|c|}
\hline Site & Historical data \\
\hline S-3 Site & $\begin{array}{l}\text { Four unlined surface impoundments constructed in 1951. Received liquid nitric } \\
\text { acid/uranium-bearing wastes via the Nitric Acid Pipeline until 1983. Closed and capped under } \\
\text { RCRA in 1988. Shallow groundwater response action (S-3 Site Pathways } 1 \text { and 2) ongoing, } \\
\text { including in situ passive treatment system (trench, siphon system, piping, and electrical). }\end{array}$ \\
\hline Oil Landfarm & $\begin{array}{l}\text { Operated from } 1973 \text { to } 1982 \text {. Received waste oils and coolants tainted with metals and } \\
\text { PCBs. Closed and capped under RCRA in 1989. Part of the Oil Landfarm Waste } \\
\text { Management Area. }\end{array}$ \\
\hline Boneyard & $\begin{array}{l}\text { Used from } 1943 \text { to } 1970 \text {. Unlined shallow trenches used to dispose of construction debris } \\
\text { and to burn magnesium chips and wood. Part of the Oil Landfarm Waste Management Area. } \\
\text { CERCLA response action completed in } 2003 \text {. }\end{array}$ \\
\hline Burnyard & $\begin{array}{l}\text { Used from } 1943 \text { to } 1968 \text {. Wastes, metal shavings, solvents, oils, and laboratory chemicals } \\
\text { were burned in two unlined trenches. Part of the Oil Landfarm Waste Management Area. } \\
\text { CERCLA response action completed in } 2003 \text {. }\end{array}$ \\
\hline $\begin{array}{l}\text { Hazardous Chemical } \\
\text { Disposal Area }\end{array}$ & $\begin{array}{l}\text { Used from } 1975 \text { to } 1981 \text {. Built over the burnyard. Handled compressed gas cylinders and } \\
\text { reactive chemicals. Residues placed in a small, unlined pit. Part of the Oil Landfarm Waste } \\
\text { Management Area. CERCLA response action completed in } 2003 \text { as part of BY/BY } \\
\text { remediation. }\end{array}$ \\
\hline Sanitary Landfill I & $\begin{array}{l}\text { Used from } 1968 \text { to 1982. TDEC-permitted, non-hazardous industrial landfill. May be a } \\
\text { source of certain contaminants to groundwater. Closed and capped under TDEC } \\
\text { requirements in 1985. Part of the Oil Landfarm Waste Management Area. }\end{array}$ \\
\hline $\begin{array}{l}\text { BCBG: A, C, and } \\
\text { Walk-in Pits }\end{array}$ & $\begin{array}{l}\text { A and C received waste oils, coolants, beryllium and uranium, various metallic wastes, and } \\
\text { asbestos into unlined trenches and standpipes. Walk-in Pits received chemical wastes, } \\
\text { shock-sensitive reagents, and uranium saw fines. Activities ceased in 1981. Final closure } \\
\text { certified for A (1989), C (1993), and the Walk-in Pits (1995). Infiltration is the primary } \\
\text { release mechanism to groundwater. }\end{array}$ \\
\hline $\begin{array}{l}\text { Bear Creek Burial } \\
\text { Grounds: B, D, E, } \\
\text { and J, and Oil } \\
\text { Retention Ponds } 1 \\
\text { and } 2\end{array}$ & $\begin{array}{l}\text { Burial Grounds B, D, E, and J: unlined trenches, received depleted uranium metal } \\
\text { and oxides and minor amounts of debris and inorganic salts. Ponds } 1 \text { and 2, built in } 1971 \\
\text { and 1972, respectively, captured waste oils seeping into two Bear Creek } \\
\text { tributaries. The ponds were closed and capped under RCRA in 1989. Certification } \\
\text { of closure and capping of Burial Grounds B and part of C was granted in February of } 1995 \text {. }\end{array}$ \\
\hline Rust Spoil Area & $\begin{array}{l}\text { Used from } 1975 \text { to } 1983 \text { for disposal of construction debris, but may have included } \\
\text { materials bearing solvents, asbestos, mercury, and uranium. Closed under RCRA in } 1984 \text {. } \\
\text { Site is a source of VOCs to shallow groundwater according to the CERCLA RI. }\end{array}$ \\
\hline Spoil Area I & $\begin{array}{l}\text { Used from } 1980 \text { to } 1988 \text { for disposal of construction debris and other stable, non- } \\
\text { radiological wastes. Permitted under TDEC solid waste management regulations in 1986; } \\
\text { closure began shortly thereafter. Soil contamination is of primary concern. CERCLA ROD } \\
\text { issued in } 1996 \text {. }\end{array}$ \\
\hline SY-200 Yard & $\begin{array}{l}\text { Used from } 1950 \text { to } 1986 \text { for equipment and materials storage. No documented waste } \\
\text { disposal at the site occurred. Leaks, spills, and soil contamination are concerns. CERCLA } \\
\text { ROD issued in } 1996 \text {. }\end{array}$ \\
\hline
\end{tabular}

BY/BY = Boneyard/Burnyard.

CERCLA = Comprehensive Environmental Response, Compensation, and Liability Act.

PCB = polychlorinated biphenyl.

RCRA = Resource Conservation and Recovery Act.

$\mathrm{RI}=$ remedial investigation.

$\mathrm{ROD}=$ record of decision.

TDEC $=$ Tennessee Department of Environment and Conservation.

$\mathrm{VOC}=$ volatile organic compound. 


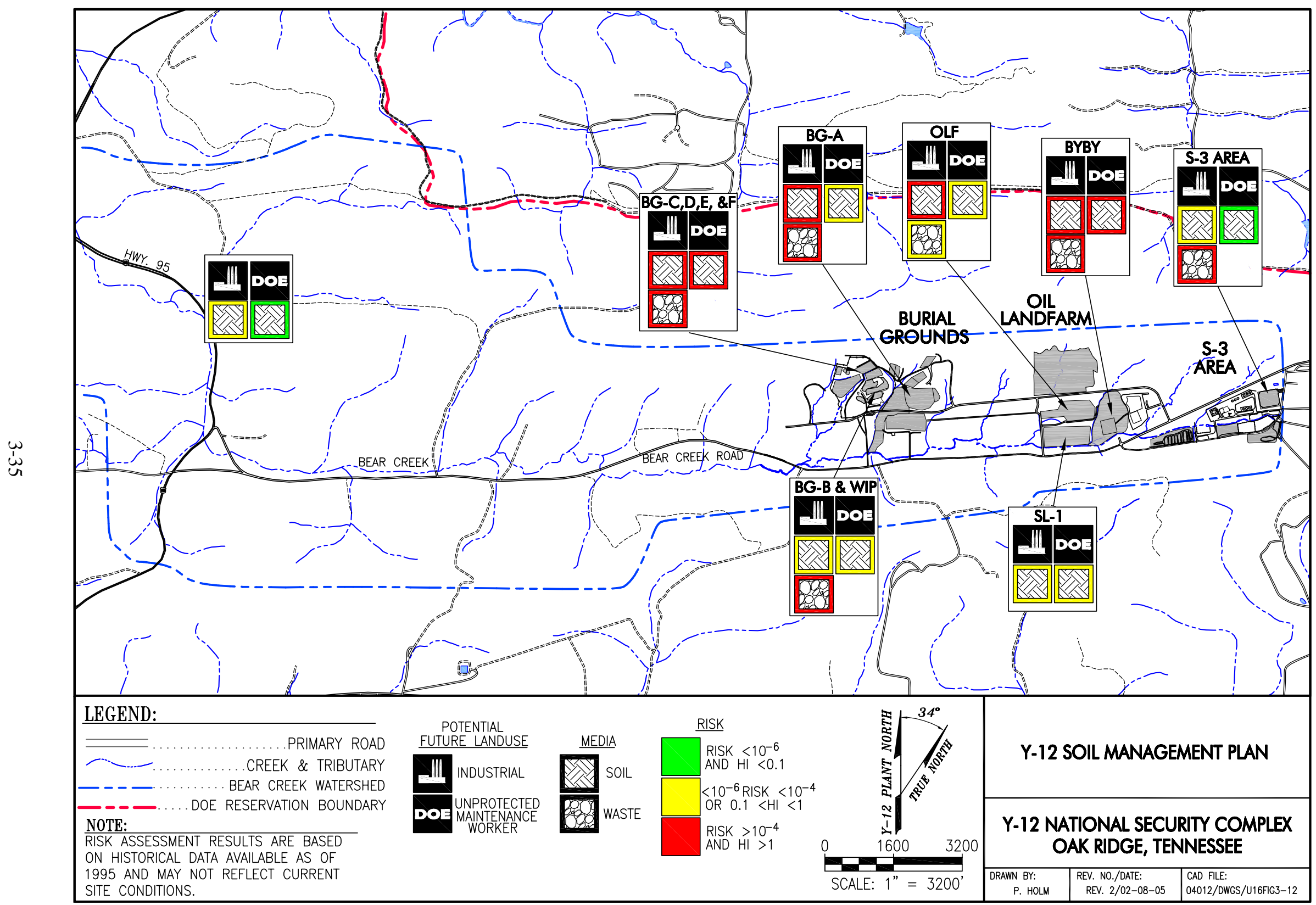

Fig. 3.12. Distribution of risks to hypothetical industrial workers and unprotected maintenance workers in Bear Creek Valley. 
04-120(E)/030205 


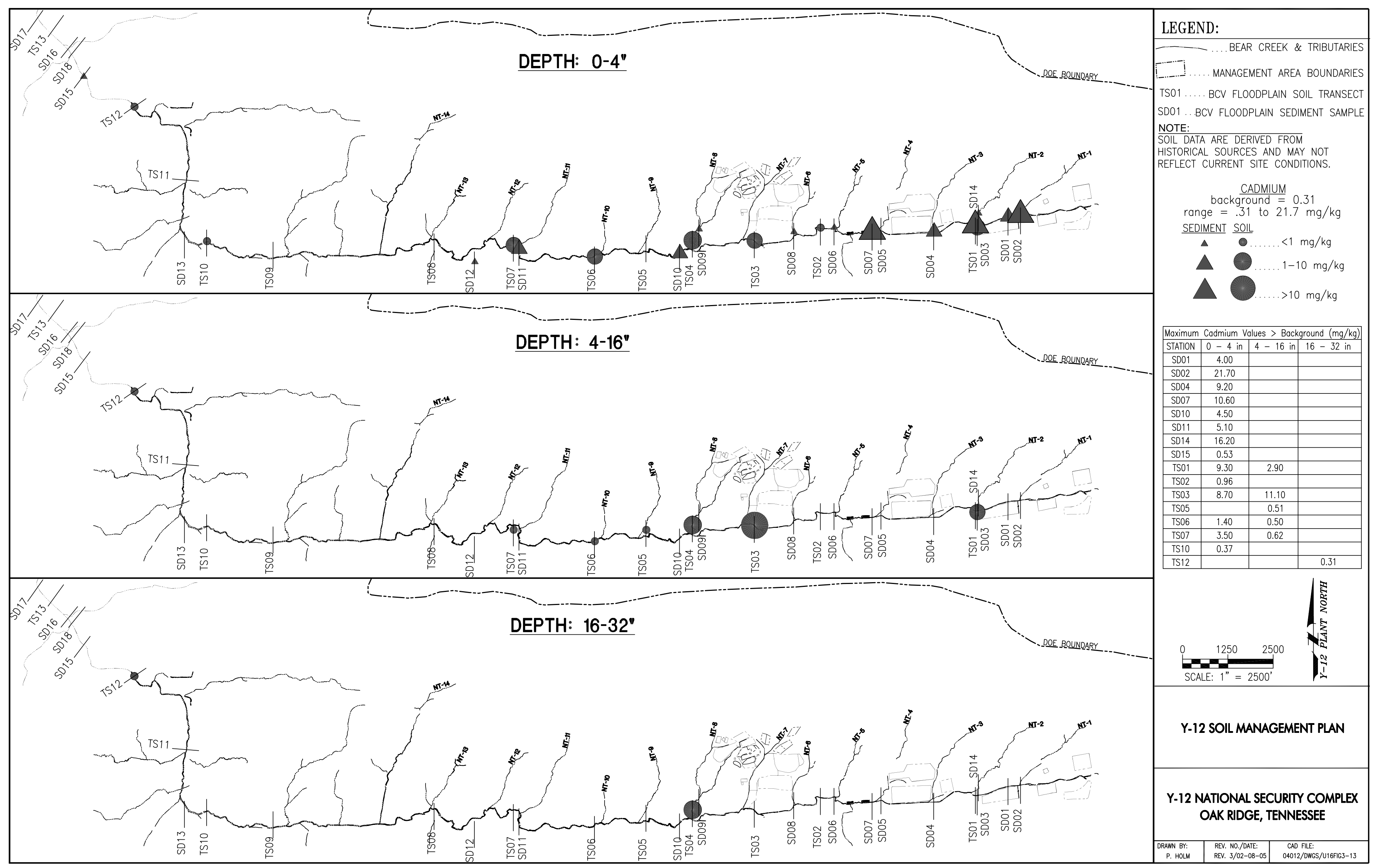

Fig. 3.13. Distribution of cadmium in Bear Creek floodplain soils and sediments. 


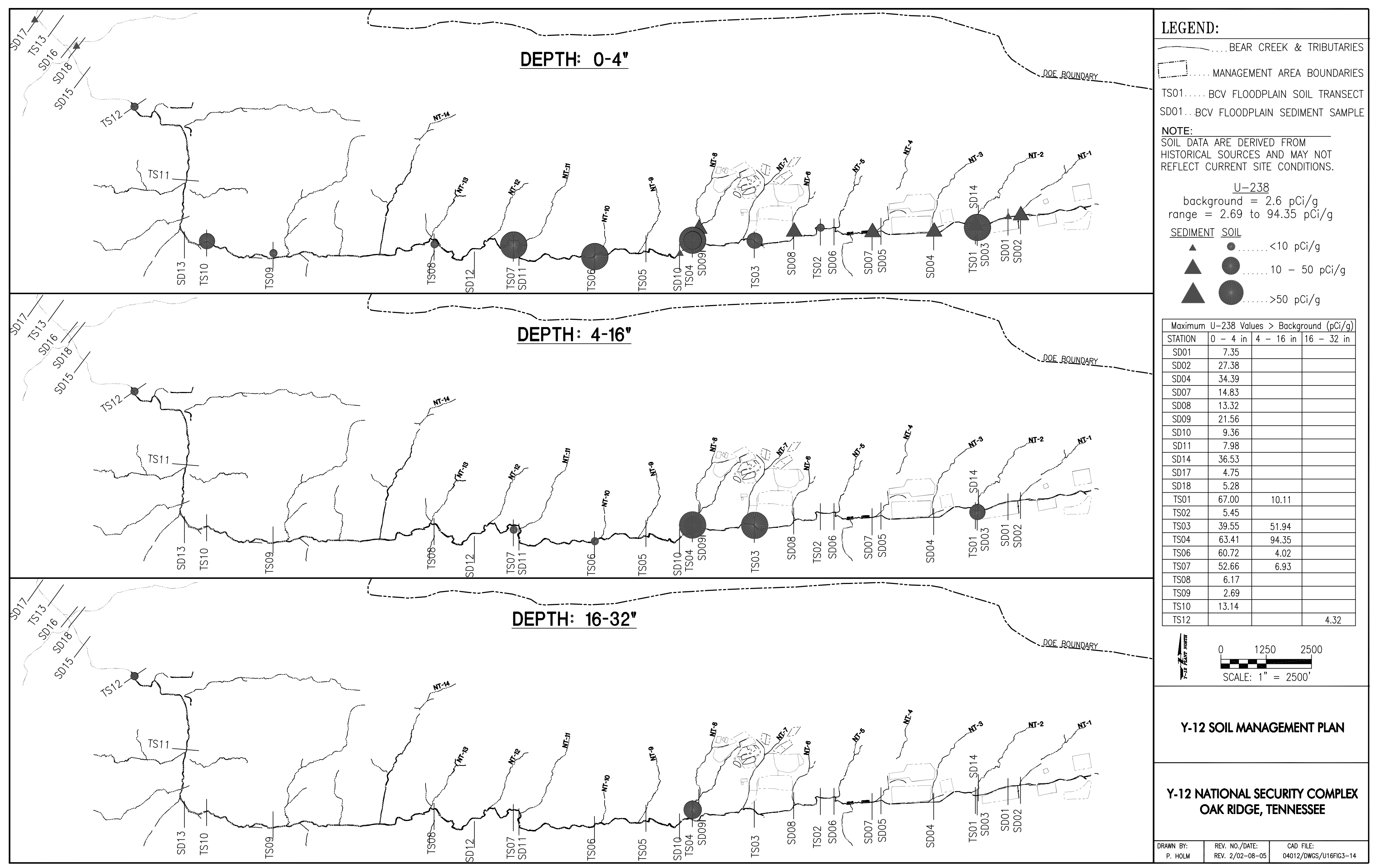

Fig. 3.14. Distribution of uranium-238 in Bear Creek floodplain soils and sediments. 


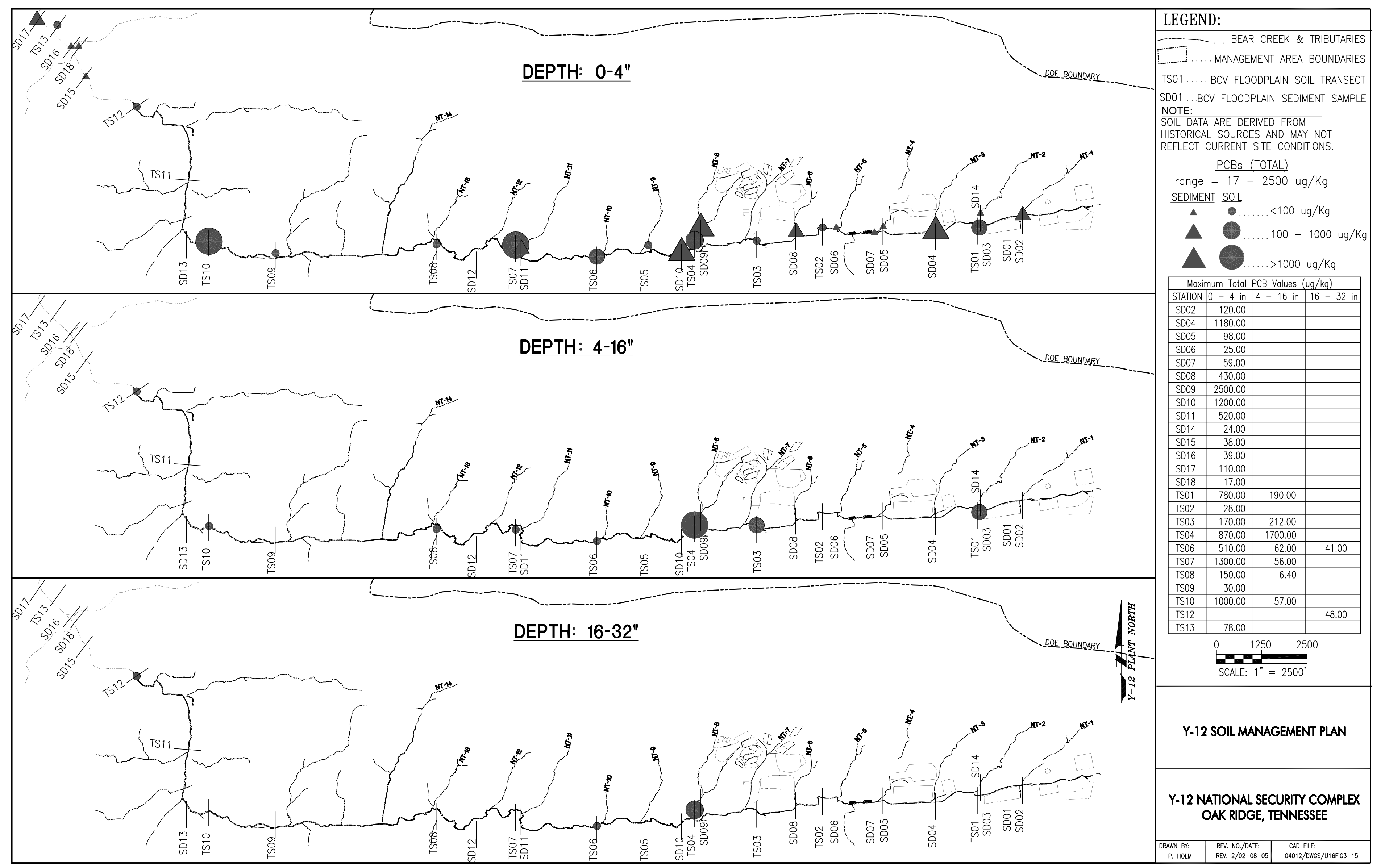


Compilation of available information from the Radiological Characterization Summary (see Sect. 3.1.1) focused on the UEFPC Watershed but also includes portions of the Bear Creek Watershed. Walkover survey results and delineated radiological areas from the summary are illustrated on Fig. 3.16. As denoted on this figure, substantial portions of BCBG and the former BY/BY vicinity are designated as radiological soil contamination areas. Appendix D contains results of the 1998 walkover survey for 61 potential radiological contamination areas identified from operational information and the FFA.

\subsubsection{Chestnut Ridge Administrative Area}

\subsubsection{Soil source areas}

The Chestnut Ridge administrative area contains several legacy hazardous waste disposal units associated with historical operations at Y-12 and other facilities on the ORR. Although not technically soil sources, two large quarries that received waste materials and are designated as legacy sites are located within the regime (KHQ and Rogers Quarry).

Additionally, active and closed non-hazardous SWDFs (landfills) servicing ORR facility operations dominate the land use within the regime (Centralized Sanitary Landfill II; Industrial Landfill V; and Construction/Demolition (C/D) Landfills IV, VI, and VII). Table 3.7 lists legacy waste management units, as well as active and closed landfill facilities within the Chestnut Ridge administrative area. Locations are illustrated on Figs. 3.1 and 3.2. Discussions of completed and planned RAs at legacy sites are presented in Sect. 3.1.4. In addition to the legacy and active waste management units noted above, a sewage sludge application area is located north of KHQ, wherein sewage treatment facility sludges from the city of Oak Ridge are applied to the land surface.

\subsubsection{Soil contamination occurrence and distribution}

Wastes, contaminated residues, and contaminated soil remain in place within all of the legacy waste management units in the Chestnut Ridge Regime. Wastes and contaminants within these units are varied and include metallic debris and metals-contaminated sludges, sediment, and flyash; waste oils; solvents; and radiologically contaminated materials. A watershed-scale RI has not been completed within the Chestnut Ridge administrative area.

Soil characterization data are limited primarily to characterization of waste materials that were disposed of in legacy units such as the Chestnut Ridge Security Pits and Chestnut Ridge Sediment Disposal Basin. For units in RCRA post-closure status (Chestnut Ridge Security Pits, Chestnut Ridge Sediment Disposal Basin, and KHQ), such source term characterization data are summarized in the RCRA post-closure permit for the Chestnut Ridge Hydrogeologic Regime (Permit No. TNHW-088). The principal source term contaminants in the Chestnut Ridge Security Pits include uranium and other metals and chlorinated solvents. The Chestnut Ridge Sediment Disposal Basin received sediments dredged from New Hope Pond, which were contaminated primarily with uranium, mercury, and other metals and low levels of PCBs. KHQ was used for the disposal of reactive materials (sodium metal) and compressed gas cylinders; source term contaminants include uranium and other metals and radiological constituents.

Under CERCLA, characterization of flyash residues in the FCAP was conducted as part of a site-specific RI conducted in 1995 (DOE 1995). Source term contaminants present at the FCAP primarily include metals (arsenic, mercury, etc.) associated with coal ash residues. A compilation of historical characterization data, risk evaluation, and contaminant fate and transport analysis was conducted for the UNC Site in 1986 in lieu of an RI, which identified radiological constituents (particularly ${ }^{90} \mathrm{Sr}$ ), metals, and nitrate as primary constituents present in the waste materials (Roy F. Weston 1986). 


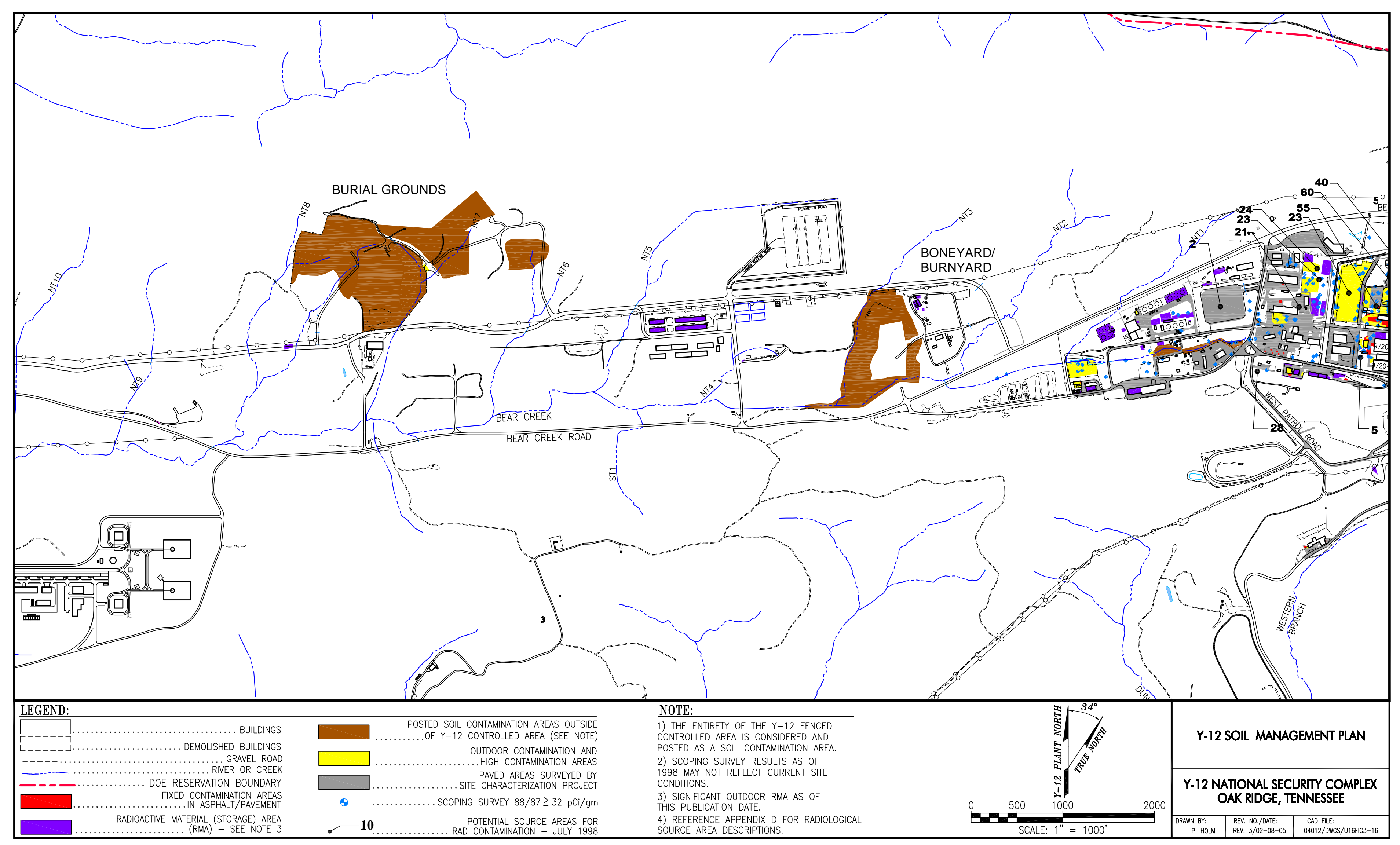

Fig. 3.16. Y-12 radiological characterization summary - Bear Creek Watershed. 
Table 3.7. Legacy and active waste management units in the Chestnut Ridge Hydrogeologic Regime

\begin{tabular}{|c|c|}
\hline Site & Historical data \\
\hline $\begin{array}{l}\text { Chestnut Ridge Sediment } \\
\text { Disposal } \operatorname{Basin}^{a}\end{array}$ & $\begin{array}{l}\text { Operated from } 1973 \text { to } 1989 \text {. Received soil and sediment from New Hope } \\
\text { Pond and mercury-contaminated soils from Y-12. Site was closed under } \\
\text { RCRA in 1989. Not a documented source of groundwater contamination. }\end{array}$ \\
\hline Kerr Hollow Quarry ${ }^{a}$ & $\begin{array}{l}\text { Operated from 1940s to } 1988 \text {. Used for the disposal of reactive materials, } \\
\text { compressed gas cylinders, and various debris. Closure (waste removal) was } \\
\text { conducted between } 1990 \text { and } 1993 \text {. Certification of closure with some wastes } \\
\text { remaining in place was approved by TDEC in February of 1995; CERCLA } \\
\text { ROD has been issued. }\end{array}$ \\
\hline $\begin{array}{l}\text { Chestnut Ridge Security } \\
\text { Pits }^{a}\end{array}$ & $\begin{array}{l}\text { Operated from } 1973 \text { to } 1988 \text {. Series of trenches for disposal of classified } \\
\text { materials, solvents, waste oils, thorium, uranium, heavy metals, and various } \\
\text { debris. Closed under RCRA in 1989. Infiltration is the primary release } \\
\text { mechanism to groundwater. }\end{array}$ \\
\hline $\begin{array}{l}\text { United Nuclear } \\
\text { Corporation Site }^{a}\end{array}$ & $\begin{array}{l}\text { Received about } 29,000 \text { drums of cement-fixed sludges and soils demolition } \\
\text { materials, and low-level radioactive contaminated soils. Closed in 1992; } \\
\text { CERCLA ROD has been issued. }\end{array}$ \\
\hline Industrial Landfill II & $\begin{array}{l}\text { Central sanitary landfill for the ORR. Detection monitoring under } \\
\text { post-closure plan has been ongoing since } 1996 \text {. }\end{array}$ \\
\hline Industrial Landfill V & $\begin{array}{l}\text { New sanitary landfill for the ORR; initiated operations in April of } 1994 . \\
\text { Baseline groundwater monitoring began in May of } 1993 \text { and was completed } \\
\text { in January of 1995. Currently under TDEC-DSWM detection monitoring. }\end{array}$ \\
\hline Industrial Landfill IV & $\begin{array}{l}\text { Permitted to receive only non-hazardous industrial solid wastes. Detection } \\
\text { monitoring under TDEC-SWM regulations has been ongoing since } 1988 \text {. }\end{array}$ \\
\hline $\begin{array}{l}\text { Construction/Demolition } \\
\text { Landfill VI }\end{array}$ & $\begin{array}{l}\text { New facility completed and initiated operations in December of } 1993 . \\
\text { Baseline groundwater quality monitoring began in May of } 1993 \text { and was } \\
\text { completed in December of 1993. Currently under permit-required detection } \\
\text { monitoring per TDEC. }\end{array}$ \\
\hline $\begin{array}{l}\text { Construction/Demolition } \\
\text { Landfill VII }\end{array}$ & $\begin{array}{l}\text { New facility; construction completed in December of } 1994 \text {. TDEC granted } \\
\text { approval to operate in January of } 1995 \text {. Baseline groundwater quality } \\
\text { monitoring began in May of } 1993 \text { and was completed in January of } 1995 . \\
\text { Permit-required detection monitoring per TDEC was temporarily suspended } \\
\text { in October of } 1997 \text { pending closure of C/D of Landfill VI. }\end{array}$ \\
\hline Rogers Quarry $^{a}$ & $\begin{array}{l}\text { Used from 1960s to } 1993 \text {. Received flyash slurry overflows from FCAP; } \\
\text { direct flyash slurry discharges; and solid process-related metallic wastes from } \\
\text { Y-12. Surface water impacts documented within the quarry (mercury, } \\
\text { selenium, and other metals). }\end{array}$ \\
\hline Former Borrow Area Waste Pile ${ }^{a}$ & $\begin{array}{l}\text { Former open pit containing soil with low levels of mercury and other metals } \\
\text { from off-site locations (Oak Ridge sewer line beltway, etc.). }\end{array}$ \\
\hline East Chestnut Ridge Waste Pile ${ }^{a}$ & $\begin{array}{l}\text { Lined RCRA interim status waste management unit for contaminated soil } \\
\text { (mercury and chromium). Currently capped with soil cover. No documented } \\
\text { releases to groundwater. }\end{array}$ \\
\hline Filled Coal Ash Pond ${ }^{a}$ & $\begin{array}{l}\text { Received Y-12 Steam Plant coal ash slurries. A CERCLA ROD has been } \\
\text { issued. Remedial action complete. }\end{array}$ \\
\hline \multicolumn{2}{|c|}{$\begin{array}{l}{ }^{a} \text { Legacy environmental waste management unit. } \\
\text { CERCLA = Comprehensive Environmental Response, Compensation, and Liability Act. } \\
\text { ORR = Oak Ridge Reservation. } \\
\text { RCRA = Resource Conservation and Recovery Act. } \\
\text { ROD = record of decision. } \\
\text { DSWM = Division of Solid Waste Management. } \\
\text { TDEC = Tennessee Department of Environment and Conservation. } \\
\text { Y-12 = Y-12 National Security Complex. }\end{array}$} \\
\hline
\end{tabular}


Characterization of contaminated soil within the East Chestnut Ridge Waste Pile as part of historical investigations and closure planning efforts indicated chromium and mercury as the primary constituents present in waste material (soil) placed into this unit. Comprehensive evaluation of human health risks has not been conducted within the Chestnut Ridge administrative area.

\subsection{CURRENT AND FUTURE ENVIRONMENTAL INFRASTRUCTURE}

Environmental infrastructure associated with remedial or closure actions at waste management units and legacy contaminated sites represents a major consideration in planning soil disturbances. Such infrastructure includes, but is not limited to, engineered caps, drainage control systems, leachate collection systems, and monitoring systems. Such infrastructure is not normally considered in detail in conjunction with the excavation/penetration permit process, although any subsurface piping and electrical systems associated with these structures would typically be included. Post-closure regulations for closed RCRA and SWDF facilities specifically prohibit disturbance or penetration of engineered caps without prior authorization from TDEC. Disturbance of engineered caps or other infrastructure installed as part of CERCLA actions are regulated through the terms of decision documents such as action memoranda or RODs under the ORR FFA. Unauthorized disturbance or damage to such infrastructure can potentially result in administrative violations, including fines or stipulated penalties under the terms of the governing regulatory authority.

Active waste management areas are also included within the scope of this section, as are administratively controlled areas under CERCLA decision documents. Both types of units may include prohibitions on excavation without prior authorization and proper controls, which should be considered during planning of soil disturbance activities.

For each of the three administrative watershed areas, the following sections provide an overview of existing remediation infrastructure, including existing engineered caps (RCRA, SWDF, or other), active waste management areas (e.g., landfills and EMWMF), administratively controlled areas under CERCLA decisions, future cap areas or excavation areas, treatment systems, and major remedial performance/compliance monitoring systems.

\subsubsection{Upper East Fork Poplar Creek Watershed (the Y-12 National Security Complex)}

Major environmental infrastructure within the UEFPC Watershed includes the multilayer engineered cap, drainage controls, and survey benchmarks associated with the closure of New Hope Pond. A soil/clay cap was installed over the Beta-4 Security Pits as part of closure of this site. Under the CERCLA ROD for the Abandoned Nitric Acid Pipeline (Plate 2), NFA was deemed protective under current and foreseeable land use at Y-12; thus, the former pipeline was left in place and marked with signs indicating its location. Planning for any soil disturbances in the vicinity of the pipeline should include evaluation of its location and the possibility of disturbance of deep contaminated soil associated with the structure. As noted in Sect. 3.1.2, the EEVOC Plume action included installation of a deep pumping well, a deep multiport well near Bldg. 9720-6, and a treatment system (Bldg. 9422-22) with associated influent and effluent piping and electrical systems.

Under the Phase I interim ROD for mercury source areas, future environmental infrastructure will include placement of an asphalt cap over mercury-contaminated surface soil between Bldgs. 9201-4 and 9201-5 and south of Bldg. 9201-5 (Fig. 3.2). Pending results of a future technical feasibility study, a horizontal dewatering well may be installed along the north sides of Bldgs. 9201-1, 9201-5, and 9204-4 to reduce the amount of contaminated influent currently being collected from building basement dewatering sumps and treated at the CMTS. 
As noted in Sect. 3.1.2, under the FFS for the UEFPC Watershed (DOE 2003a), a potential future soils removal action may potentially involve excavation and disposal of 25,000 to 40,000 $\mathrm{yds}^{3}$ of soil containing COCs above industrial land use remedial goals, primarily in the western portions of Y-12. Although remediation infrastructure such as caps is not included as part of the alternative, long-term monitoring adjacent to deep soil excavation areas is specified as part of remedial performance assessment. Plate 2 provides a detailed compilation of current and future environmental infrastructure, along with source area locations, radiologically contaminated areas, and indicators for required reviews prior to soil disturbance.

\subsubsection{Bear Creek Watershed}

Within the Bear Creek Watershed, environmental infrastructure associated with past waste management unit closures, CERCLA actions, and active waste management facilities covers a large percentage of the valley (Fig. 3.17). The former S-3 Ponds, Oil Landfarm, and BCBG were all closed with multiplayer engineered caps with associated drainage controls and survey benchmarks that require protection, routine inspection, and maintenance. A leachate control system was also installed as part of the closure of portions of BCBG, which must also be maintained as stipulated in the RCRA post-closure permit. Sanitary Landfill I, the Rust Spoil Area, and the SY-200 Yard include maintained soil/clay and vegetative covers.

CERCLA RAs at BY/BY included capping of portions of the site and reconstruction of the NT-3 channel following excavation of the most contaminated wastes. Protection of the revegetated site is required. Baseline channel profiles were created following reconstruction of the channel and protection and log-term monitoring of the channel configuration is required as part of post-remediation activities. Additionally, in situ treatment systems (i.e., passive treatment trench, siphon pump system, and treatment boxes) were installed as part of the Pathways 1 and 2 RAs at the former S-3 Ponds. These treatment systems and associated performance monitoring network remain active under the remedial decision.

Active waste management facility infrastructure includes the West End Treatment Facility and associated physical structures, along with the EMWMF, which is undergoing expansion. Multiple waste storage facilities (Low-Level Above Grade Storage Facility, DARA Soils Storage Facility, etc.) also occupy substantial footprints within the watershed.

An extensive compliance and remedial performance monitoring network exists within the watershed, which requires protection, routine inspection, and maintenance. Specifics regarding locations of monitoring systems are not included in this plan and are subject to change over time. Current information on compliance monitoring systems may be found in the RCRA post-closure permit for the Bear Creek Hydrogeologic Regime (TNHW-116), the Water Resources Restoration Program (WRRP) Annual Sampling and Analysis Plan, and the annual RER. Other monitoring is periodically conducted under DOE Order 5400.1; information on this program may be obtained through the Y-12 ES\&H Division.

\subsubsection{Chestnut Ridge Administrative Area}

Partial removal of debris and material was completed for KHQ as part of RCRA closure; however, contaminated sediments and non-visible debris were left in place in the quarry. The only environmental infrastructure at KHQ includes fencing and signage to maintain physical access controls at the site. Multilayer engineered caps and drainage controls have been installed at the UNC Site, Chestnut Ridge Security Pits, and the Chestnut Ridge Disposal Basin as part of RCRA closures and these components 


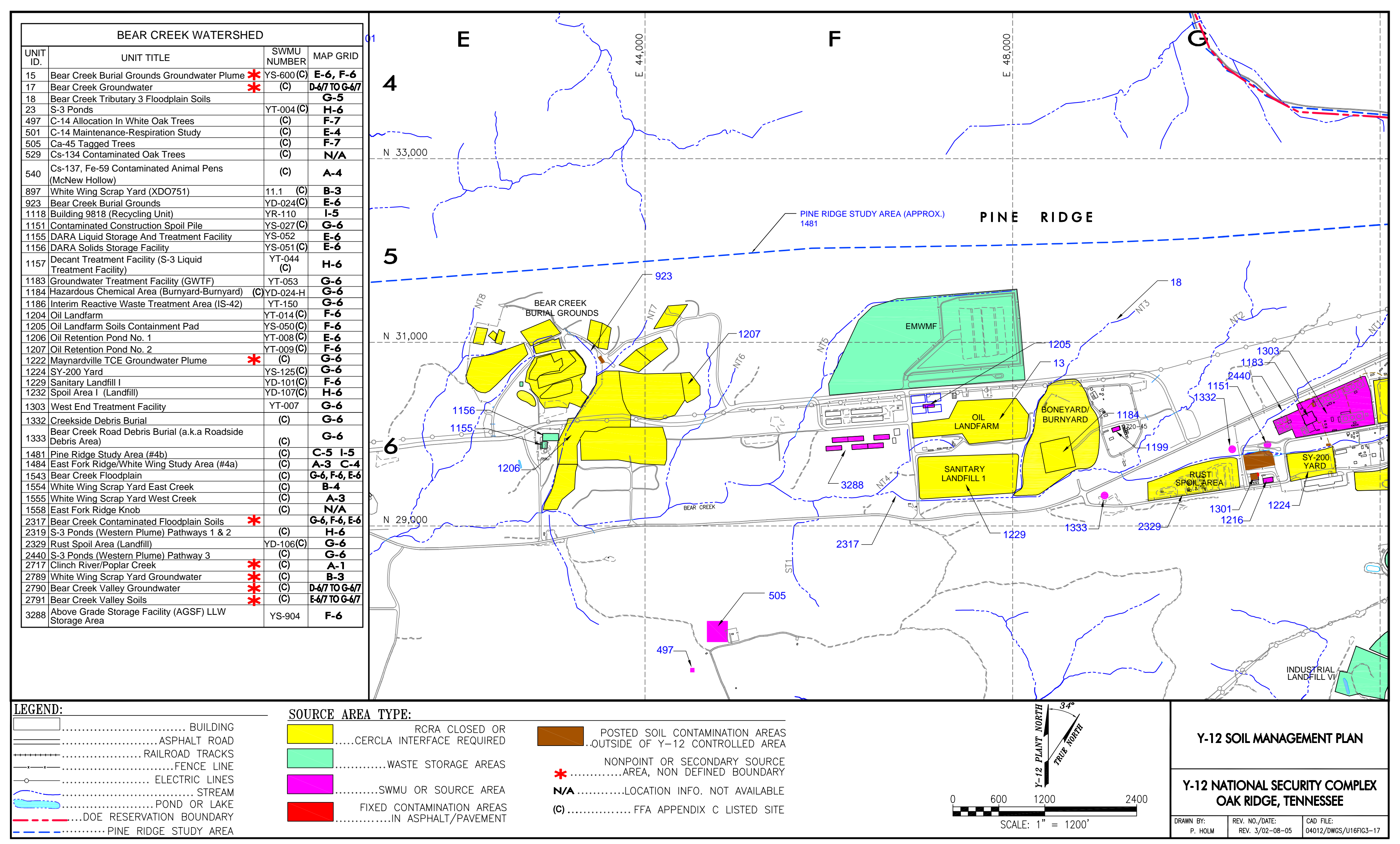

Fig. 3.17. Source areas, environmental infrastructure, and radiological contamination areas in the Bear Creek Watershed. 
have ongoing maintenance requirements under RCRA post-closure permits and CERCLA decision documents. All sites regulated under the terms of the RCRA post-closure permit (TNHW-088) include periodic inspection and maintenance of survey benchmarks at the sites. The Centralized Sanitary Landfill II is closed and capped with a methane venting system and maintained in accordance with Tennessee solid waste management regulations. At FCAP, drainage controls, a reconstructed flyash impoundment dam, vegetative cover, and artificial wetland represent major infrastructure components of the remedy that required protection and maintenance. Figure 3.18 illustrates the extent of unit covers/caps, as well as active waste management units, radiological areas, and indicators for required planning reviews in the Chestnut Ridge administrative area.

All of the above units include provisions for post-closure monitoring (RCRA or SWDF) or CERCLA performance assessment monitoring. Thus, groundwater and/or surface water monitoring systems are in place at these units, which require protection, periodic inspections, and maintenance. Specifics regarding locations of monitoring systems are not included in this plan and are subject to change over time. Current information on compliance monitoring systems may be found in the RCRA post-closure permit for the Chestnut Ridge Hydrogeologic Regime (TNHW-088), the annual RER, and respective SWDF permits for landfill facilities. Other monitoring is periodically conducted under DOE Order 5400.1; information on this program may be obtained through the Y-12 ES\&H Division. 


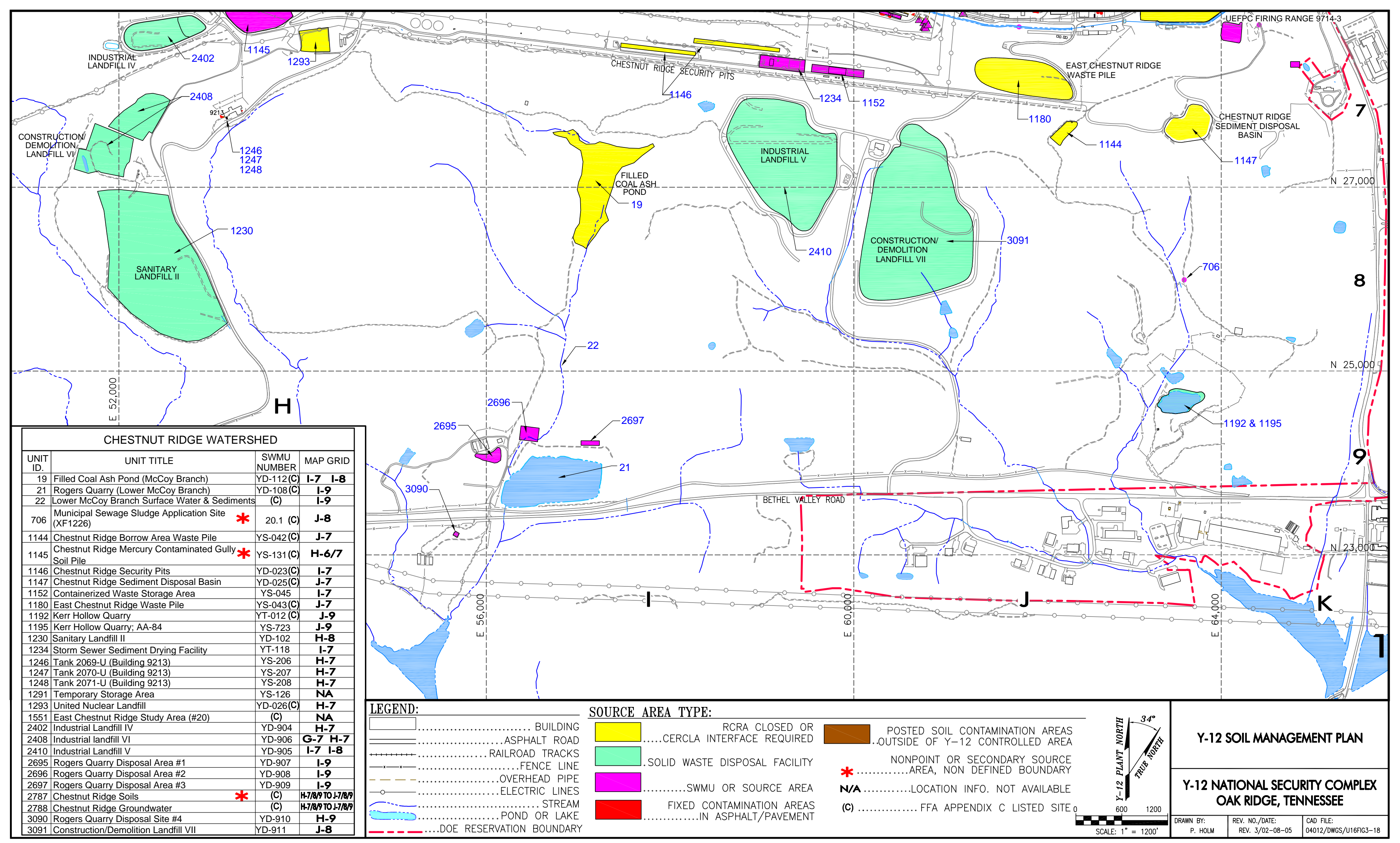

Fig. 3.18. Source areas, environmental infrastructure, and radiological contamination areas in the Chestnut Ridge administrative area. 
04-120(E)/030205 


\section{WASTE MANAGEMENT PROTOCOLS AND PROCEDURES}

The following sections discuss constraints and associated decision-making for on-site management and final disposition of Y-12 excavated soils. Section 4.2 discusses staging of the excavated soil to meet site BMPs. Section 4.3 covers minimum characterization protocols, and Sect. 4.4 discusses selection of a disposal option based on soil characterization and WAC of disposal facilities. Section 4.5 presents an overview of transportation issues related to soil disposal.

\subsection{OVERVIEW OF THE SOIL DISPOSITION PROCESS}

At Y-12, any soil that is excavated must be managed per regulatory requirements and associated BMPs. In general, it is considered a BMP to return soil excavated during routine operations and maintenance activities to the same area from which it was excavated unless the soil shows signs of gross contamination. This beneficial re-use of soil is consistent with CERCLA and RCRA policies regarding return of contaminated media to the AOC or SWMU. Soil that is not subject to beneficial re-use must be managed per applicable regulations and BMPs; characterized with respect to regulated constituents; and transported for disposal in compliance with requirements of federal, state, and local regulations and ordinances and DOE and Y-12 policies. Under the ORR FFA (FFA 1992), the discovery of contaminated excavated soils at previously unidentified locations on ORR may trigger notification and corrective action requirements in addition to regulated-waste management requirements.

\subsection{ON-SITE MANAGEMENT OF EXCAVATED SOILS: REGULATORY REQUIREMENTS AND BEST MANAGEMENT PRACTICES}

The purpose of excavated soil management BMPs is to prevent migration of contaminants across media (e.g., from soil into surface water) or to soils outside existing contamination areas. At a minimum, excavated soils must be managed so that the soil is not wind-dispersed and contaminated run-off cannot be introduced to the soil or other environmental media. The concept of as low as reasonably achievable applies to the management of excavated soil such that the volume of potentially contaminated soil generated and dispersal of contaminants (run-on and contaminated run-off, wind, etc.) from a soil staging pile is minimized to the maximum practical extent.

\subsubsection{Clean Water Act Best Management Practices}

On-site management of excavated soil must be in compliance with CWA BMPs. EPA initiated a national stormwater permitting program in 1990, which applied to industrial activities, construction sites greater than or equal to 5 acres, and urban run-off from larger cities. CWA Stormwater Phase II regulations in 1999 addressed additional urbanized areas, certain cities with population over 10,000, and construction activities of 1 to 5 acres. TDEC, Division of Water Pollution Control, implements the EPA Phase I and Phase II regulations in Tennessee. Y-12 is currently regulated under a stormwater permit for normal industrial activities and soil disturbances, which is incorporated into the current NPDES permit. When an activity or project plans to disturb 1 acre or more, then a stormwater permit is applied for and issued to the project by TDEC. DOE has also submitted a Stormwater Pollution Prevention Plan for Y-12. Depending on the project location, the project will be subject to meeting conditions of the stormwater permit and management of soil consistent with the overall Y-12 permit and stormwater pollution prevention plan.

TDEC, Division of Water Pollution Control, implements the Phase I and Phase II Stormwater regulations in Tennessee. State BMP guidance is found in the Division of Water Pollution Control 
"Tennessee Erosion and Sediment Control Handbook": (http://www.state.tn.us/environment/wpc/ sed_ero_controlhandbook/). The handbook is designed to guide planners, developers, engineers, and contractors on the proper selection, installation, and maintenance of BMPs, and is intended for use during the design and construction of projects that require erosion and sediment controls to protect waters of the state. Typical BMPs include installing silt fences, using proper grading, and leaving natural vegetation in place for as much of the construction period as possible. Residual water in excavated soil should be field-sampled for $\mathrm{pH}$ and conductivity and may be 'filtered' through filter fabric/filter bags and/or hay bales prior to discharge along surface drainage pathways.

\subsubsection{Contaminated Soil Regulatory Requirements and Best Management Practices}

Principal regulatory requirements that apply to management of excavated soil at Y-12 include CERCLA, RCRA, TSCA, DOE Orders, and EPA guidance for the management of radiologically contaminated materials.

If excavated soil is suspected of exhibiting a RCRA-hazardous characteristic [e.g., it is believed that the soil would likely fail the RCRA toxicity characteristic leaching procedure (TCLP) for mercury] or is suspected of containing a RCRA-listed hazardous waste (e.g., soil contaminated from a spill of a U- or Plisted chemical), the soil must be managed as RCRA hazardous until sufficient information is obtained to determine the regulatory status of the material.

RCRA-hazardous soil piles should be stored under a structure and managed such so that neither run-off nor leachate are generated that would be subject to regulation. Specific staging pile management elements include: (1) liquids (or materials containing free liquids) are not added to the pile, (2) the pile is protected from surface water run-on, (3) the pile is designed and operated to control wind dispersal by means other than wetting, and (4) the pile will not generate leachate. If these conditions cannot be met, the generator must meet conditions described in 40 CFR 264.251 for liners, leachate collection and removal, etc., and 40 CFR 264 Subpart F (RCRA SWMUs). There is a 1-year time limit for accumulation of materials subject to LDRs, except for remediation wastes in a staging pile (40 CFR 268.50). EPA recently issued guidance on BMPs for contaminated soils that are staged and treated on-site: (http://www.epa.gov/epaoswer/hazwaste/ca/resource/guidance/rem_eval/bmpfin.pdf).

\subsubsection{PCB-contaminated soils}

Excavated soil from historically contaminated areas may contain $\mathrm{PCBs}$ at levels requiring management under TSCA. Although PCBs in soils at Y-12 are likely to be the result of historical spills caused by past operations or practices, new PCB spills may be discovered, which are usually identified by soil staining. The NEPA screening process (see Sect. 2.2) should identify locations of historical spills and their regulatory status before an excavation project begins. If evidence of a PCB spill is discovered during excavation, and remediation is not scheduled under the scope of an existing RA, PCB-contaminated soil in the spill area should be excavated and the ground surface restored to its original configuration by backfilling with clean soil. Requirements for cleanup of PCB spills in soil are explained in the ORR-PCBFederal Facilities Compliance Agreement, rev. 2, 8/19/97. TSCA requirements apply to PCB-contaminated soils in storage. If the level of PCBs is $\geq 50 \mathrm{ppm}$, the soil should be stored as PCB remediation waste in compliance with 40 CFR 761 Subparts D and N. Excavated soil contaminated with PCB Bulk Waste (e.g., dry paint chips from building demolition) may have less restricted storage and marking requirements for the first 180-days following excavation if the contaminated soil can be stored near the point of generation; the generator should contact the Y-12 PCB Coordinator in the Environmental Compliance Organization within the Y-12 ES\&H Division to determine if PCB-contaminated excavated soil qualifies as PCB Bulk Waste. 


\subsubsection{Other radiological and mixed waste contaminated soils}

As a result of the historical activities, radioactive materials may be found during soil excavation in many areas at Y-12. Project-specific RADCON surveys/evaluations are conducted prior to excavation to delineate areas and levels of radiological contamination. Within a RADCON area or CERCLA AOC, soils contaminated with low levels of radiological contaminants are usually returned to the excavation area pending final remediation. Residual radioactive material in soil is managed in accordance with DOE Order 5400.5. DOE guidelines for residual concentrations of thorium and radium in soil, concentrations of airborne radon decay products, allowable external gamma radiation levels, and residual surface contamination concentrations were based on existing radiological protection standards (e.g., 40 CFR Part 192; Nuclear Regulatory Commission Regulatory Guide 1.86 and subsequent Nuclear Regulatory Commission guidance on residual radioactive material) subject to management and disposition as radiologically contaminated material.

Requirements for managing radioactive wastes, including radiologically contaminated soils, are established in DOE Order 435.1 and the DOE M 435.1-1 Chg. 1 Radioactive Waste Management Manual, Change 1, 6/19/01 (http://www.llnl.gov/es_and_h/sourcematerial/doem4351-1c1.pdf). The manual requires that the generator design, inspect, and use corrective actions, as necessary, to ensure that radiologically contaminated waste is contained and that waste container integrity is maintained throughout the storage period. General BMPs for management of excavated soil pending disposition or beneficial re-use within a RADCON area include securing the waste to prevent stormwater run-on/run-off, erosion, and wind dispersal of contaminants. The requirements of DOE Order 435.1 are implemented at $\mathrm{Y}-12$ through Procedure Y71-936. Joint EPA/DOE guidance on the storage of mixed low-level radioactive/hazardous waste, including mixed waste soils, is found at http://www.epa.gov/radiation/ mixed-waste.

\subsection{CHARACTERIZATION OF EXCAVATED SOIL FOR DISPOSITION}

This section describes the stepwise characterization of soil to determine potential disposition pathways. Because of widespread historical contamination at Y-12, soil in most areas of the plant may be suspected of containing some level of contamination. Prior to the start of work, all potential excavation areas must be evaluated with respect to potential site-related contaminants; the Y-12 CERCLA screening, Excavation Permit process, and NEPA screening process described in Chap. 2 of this document are used to evaluate the types and levels of contaminants and identify any controls and restrictions on excavated soil. When working outside areas having well-documented levels of contamination, additional research may be necessary. Preliminary characterization of excavated soils should be based both on PK and visual inspection of the soil.

The PK process includes gathering information on historical and current facility/area operations, the regulatory history (e.g., prior or current investigations/remediation under RCRA, TSCA, or CERCLA), chemical storage and spill histories, and any available data (e.g., measurements obtained by Y-12 RADCON staff) to address worker safety during excavation. PK typically is obtained by research of historical records and existing characterization reports, as well as interviews of facility/area personnel prior to the start of fieldwork. A thorough PK investigation can help to minimize project delays and costs associated with contaminant identification and waste categorization after soil has been excavated. Radiological green tags are needed for disposition of clean soil.

Batches of excavated soil should be examined for evidence of staining or strong odors, presence of liquid mercury, PCBs, solvents or oil from past spills, or evidence of subsurface debris (e.g., drums or asbestos). Soils excavated from areas adjacent to current and former facility loading docks or from product storage areas (e.g., tank farms) should be examined carefully for visual signs of product leaks. 
Evidence of gross contamination of excavated soil may trigger notification and/or remediation requirements. For leaks from petroleum USTs, TDEC guidance on reporting and corrective actions is found at http://www.state.tn.us/environment/ust/reprtreq.php.

Excavated soil for which PK indicates little or no known contamination, and that does not show signs of gross contamination (e.g., visual signs of staining, free mercury, strong odors, etc.), may be subject to beneficial re-use and returned to the excavation without further characterization. Soils from one cleanup area may not be mixed with or deposited into soil in another remediation or clean-soil area without permission of the FFA project leader.

Soil that is not eligible for beneficial re-use and must be disposed of at a landfill or spoil pile, and for which there is insufficient PK, requires sampling and laboratory analyses to determine its regulatory status (e.g., for PCBs or RCRA TCLP) and to subsequently document that it meets the acceptance criteria of the receiving facility. Excavated soil at Y-12 for which there is insufficient PK to make a regulatory/waste disposition determination is analyzed for uranium isotopes. Additional analytes (e.g., PCBs, mercury, and TCLP metals) may be selected depending on whether the site is within a suspected mercury or PCB area, operational history of the site, historical contaminants associated with that location, and the level of documentation that will be required by the disposal facility. Note: if credible PK is obtained, sampling and analysis may be minimal or unnecessary.

Waste that is volumetrically contaminated with radionuclides must be characterized by analysis of representative sample(s) or scanned at a TDEC-reviewed nondestructive assay facility prior to disposal. DOE has published methods for evaluating environmental and waste management samples on their website at http://www.pnl.gov/methods/, which includes as an appendix guidance for selecting and qualifying methods to meet analytical data quality objectives.

\subsection{ESTABLISHING A WASTE DISPOSITION PATHWAY}

Prior to fieldwork, the generator, with assistance from the Y-12 Waste Operations Organization, evaluates various disposition pathways for soil that will not or cannot be returned to the excavation area. This planning step includes evaluating all disposal options and matching the soil characteristics with the potential destination facilities' criteria for acceptance.

On-site facility acceptance criteria are tied to the site-specific permit limitations issued by TDEC. It is the generator's responsibility to determine if excavated soils can meet the intended facility's acceptance criteria. In addition, advanced written notice and approval of each soil shipment are usually required. For example, for Y-12 on-site waste management facilities that are managed by a DOE contractor/subcontractor, written documentation of the characteristics of the excavated soil must be provided in accordance with the facilities' waste acceptance plan and approved before the soil is transported from the excavation site. Y-12 Waste Operations Organization personnel within the Y-12 ES\&H Division assist the generator in submitting requests for disposal and obtaining necessary approvals.

\subsubsection{On-site Disposal Options and Associated Waste Acceptance Criteria}

On-site options for disposition of excavated soils include Class II (Sanitary/Industrial), Class II Classified Waste, Class IV (C/D) SWDFs, and C/D Spoil Areas. These facilities are permitted by TDEC under TN Rules 1200-1-11-.03 through 1200-1-11-.07 (http://www.state.tn.us/sos/rules/1200/1200-

01/1200-01-11/1200-01-11.htm). General restrictions on soils disposed at ORR SWDFs include 
prohibitions on free liquids (as determined by visual inspection). The following subsections discuss additional restrictions and requirements.

\subsubsection{Evaluation of excavated soils with RCRA-hazardous constituents}

RCRA hazardous wastes are prohibited from disposal at ORR Class II and Class IV SWDFs. The division Environmental Officer and Y-12 Waste Operations Organization personnel within the Y-12 ES\&H Division assist the generator in determining the applicability of RCRA hazardous waste regulations and restrictions to excavated soil. Sanitary/industrial wastes cannot exhibit RCRA-hazardous characteristics, cannot contain a" listed" RCRA-hazardous waste, nor can they be subject to the RCRA LDRs.

Note that by its nature, soil is not a RCRA 'solid waste' and, therefore, cannot be a RCRA hazardous waste. However, if soil exceeds RCRA toxicity characteristic thresholds (e.g., for heavy metals such as lead or mercury) when excavated, then several treatment and disposal constraints apply. These include LDRs, a requirement to eliminate the hazardous characteristic prior to disposal, and a requirement to treat the soil for any underlying hazardous constituent(s) that may reasonably be expected to be present at 10 times RCRA Universal Treatment Standards (UTS).

Soil contaminated with RCRA-listed wastes also must comply with LDR treatment standards, and any constituents reasonably expected to be present at 10 times the UTS levels must be treated. However, the treated soil remains listed and, therefore, ineligible for disposal at ORR SWDFs unless a "no-longercontained" determination at the point of generation has been obtained from the regulator.

In addition, EPA published "Guidance on Demonstrating Compliance with the Land Disposal Restrictions (LDR) Alternative Soil Treatment Standards," EPA/530/R-02/003, July 2002 (http://www.epa.gov/epaoswer/hazwaste/ldr/soil_f4.pdf) to assist the generator in these determinations.

\subsubsection{Evaluation of excavated soils with radiological constituents}

In general, sanitary wastes destined for the ORR SWDFs must be known by PK to be non-radioactive. Specific radiological WAC for ORR SWDFs include restrictions on both volumetric and surface contamination, as follows.

\section{Volumetric Contamination}

- If excavated soil is volumetrically contaminated and destined for disposal at an ORR Class II SWDF, then the waste must be documented as meeting Tennessee Division of Radiological Health screening criteria. These criteria are documented in the TDEC "Memorandum of Understanding on Volumetric Screening Criteria for 18 Radionuclides," dated March 25, 2003.

- If excavated soil destined for disposal at either an ORR-classified waste SWDF or C/D facility, and is volumetrically contaminated with uranium only, then the specific activity of the waste must be $<35 \mathrm{pCi}$ of total uranium per gram of soil (note: a sampling and analytical summary is required as documentation).

- If excavated soil destined for disposal at either an ORR-classified waste SWDF or C/D facility is volumetrically contaminated with radionuclides other than uranium and its daughters, then the generator must complete RESRAD modeling and prepare an authorized radiological limits justification package for DOE approval [note: this requirement ensures that the total dose equivalent of the soil is comparable to the allowable effective dose equivalent (per DOE Order 5400.5 and DOE 
Memorandum EH-412, "Application of DOE 5400.5 Requirements for Release and Control of Property Containing Residual Radioactive Material,” dated November 17, 1995)].

- Excavated soil to be dispositioned at a C/D spoil area must not exceed background levels of radionuclides.

\section{Surface Contamination}

If excavated waste (e.g., debris in excavated soil) is surface-contaminated, then the waste must meet the surface release criteria established in DOE Order 5400.5, "Radiation Protection of the Public and the Environment" prior to movement outside of the Y-12 controlled area.

\subsubsection{Evaluation of "Special Wastes"}

ORR maintains TDEC-permitted Class II Industrial SWDF capacity for sanitary/industrial wastes generated on the reservation. Y-12 Waste Operations Organization personnel within the Y-12 ES\&H Division assist the generator in evaluating Class II SWDFs as disposal options for industrial wastes, commercial wastes, and C/D wastes. The active ORR Class II SWDF facility is a lined landfill having a leachate collection system. The generator must obtain facility-operating contractor pre-approval and must sign a waste description (UCN-2109 form) prior to disposal of excavated waste at these facilities.

TDEC has approved certain Special Wastes for disposal at ORR SWDFs. These Special Wastes include, but are not limited to, the following waste types that could be encountered during excavation of soil:

- wastes having volumetric radionuclide contamination: total uranium $<35 \mathrm{pCi} / \mathrm{g}$ and/or uranium isotopes (i.e., U-234, U-235, U-238) with other radionuclides (H-3, C-14, Co-60, Sr-90, Tc-99, Cs-137, Eu-152, Eu-154, Ra-226, Th-230, Th-232, Np-237, Pu-238, Pu-239, or Am-241) below dose-based screening levels established by the Tennessee Division of Radiological Health (TDRH) and TDEC (2003); special waste documentation requirements apply to volumetrically contaminated wastes to be landfilled;

- $\quad$ PCB-detectable [> 2 ppm and < 50 ppm PCBs (e.g., in paint chips)] C/D wastes (note: PCB detectable paint wastes must not have other chemical or radiological COCs);

- $\quad$ soils contaminated with friable and non-friable asbestos;

- $\quad$ soils containing beryllium oxide $(\mathrm{BeO})<1000 \mathrm{ppm}$;

- $\quad$ petroleum product-contaminated soil; and

- $\quad$ soils contaminated with respiratory hazardous waste/fiberglass with loose fiberglass.

Volumetrically contaminated materials not meeting the TDRH/TDEC radiological screening criteria must be further characterized using RESRAD modeling, and a justification package approved by DOE prior to shipment.

A permit modification to allow acceptance of PCB bulk product wastes (e.g., applied paint on construction/demolition debris) containing $>50 \mathrm{ppm}$ PCBs is pending. Also, special waste packaging, including double wrapping in 0.6-mil plastic, is required for $\mathrm{BeO}$ and asbestos-containing wastes. 
The generator works in cooperation with Y-12 Waste Operations Organization personnel within the Y-12 ES\&H Division to complete an application for disposal of a Special Waste. Per TDEC, any person applying for a Special Waste Permit must submit a completed Waste Evaluation Fee Worksheet (Form CN-0932) application, disposal fee, and a completed Special Waste Data Collection Form and attachments for each new waste stream (see http://www.state.tn.us/ environment/permits/specwste.php). The types of detailed information that must be provided for disposal of a Special Waste include a chemical and physical description of the waste, the amounts and frequencies of disposal, a description of the process generating the waste, and identification of the facility receiving the waste.

\subsubsection{Classified Waste Disposal}

Separate Class II SWDF capacity for DOE ORR-classified solid wastes is permitted by TDEC. Although wastes types are generally limited to paper, wood, cardboard, plastics, rubber, and standard industrial metals, bulk industrial process wastes and C/D wastes may be accepted via TDEC Special Waste Permit on a case-by-case basis. The Y-12 Classification Office is a required interface if an ORRclassified landfill is potentially to be used as a disposal option. A minimum of 3 working days advance notification and a signed UCN-2109 form are required prior to the delivery of non-routine waste such as C/D waste.

\subsubsection{Class IV Facility Construction/Demolition Waste Disposal}

ORR also maintains TDEC-permitted Class IV C/D SWDF capacity. Class IV facilities accept wastes resulting from building $\mathrm{C} / \mathrm{D}$ and road building or repair, including soil, rock, road spoils, paving materials, concrete, rebar, bricks and other masonry, polyethylene sheeting, sheetrock, roofing materials, etc. Special wastes (e.g., non-friable asbestos, fly ash, and respiratory wastes) are accepted on a case-bycase basis. Facility-operating contractor pre-approval and a completed waste manifest (UCN-2109 form) are required prior to disposal.

\subsubsection{On-site Construction/Demolition Spoil Areas}

ORR C/D Spoil Areas are used for on-site disposition of clean earthen materials that can be used for fill. Spoil areas are used to save valuable SWDF capacity. Acceptable spoil materials include clean, non-contaminated gravel, soil, rock, concrete, brick, cinder/concrete bricks, clay products, and asphalt. Disposition in a spoil pile should not be used if excavated soil is suspected of containing any chemical contamination, low-level radioactive waste, or other radiological contamination above background. No free liquids are allowed. A minimum of 1 day advance notification, and a signed UCN-2109 form with a valid "green tag" are required.

\subsubsection{Oak Ridge Reservation Environmental Management Waste Management Facility}

EMWMF is a specially constructed landfill designed as part of a CERCLA remedy to accept wastes from DOE ORR CERCLA remediation projects, including those at Y-12. Although the EMWMF is not available for disposal of contaminated non-remediation soils, "clean" soil from Y-12 operations is accepted as fill/cover material at EMWMF on a case-by-case basis. Clean soil does not require a "green tag" or submission of a waste manifest. However, drivers transporting clean excavated soil to EMWMF must have special training. The Y-12 Waste Operations Organization personnel within the Y-12 ES\&H Division assist the generator in determining the suitability and availability of this disposition path for excavated soil that will not be returned to the excavation site. 


\subsubsection{Off-site Disposal Options}

At present, excavated soil from Y-12 is not released off-site for unrestricted use. Excavated soil that cannot be beneficially re-used on-site and does not meet WAC for ORR Sanitary/Industrial Class II or Class IV Landfills must be disposed as waste off-site. Potential off-site disposition options include the Nevada Test Site and commercial facilities (e.g., Envirocare of Utah). Each of these facilities has WAC that must be met prior to disposition.

\subsubsection{Nevada Test Site}

The Nevada Test Site accepts low-level radioactive waste from DOE facilities. DOE Order 435.1 requires that all low-level radioactive waste facilities, operations, and activities have waste acceptance requirements describing the radiological, physical, and chemical limitations of waste that can be accepted and safely managed in the facility. Compliance with stringent WAC and associated PK documentation is required, and waste must be manifested and pre-approved by the facility management contractor. At present, wastes from outside the state of Nevada must be certified as "no-RCRA added," which would preclude disposition of historical mercury-contaminated waste at this location. The Nevada Test Site WAC are detailed at http://www.nv.doe.gov/ programs/envmgmt/RWAP/ntswac.htm.

\subsubsection{Other commercial options}

The Envirocare of Utah facility is a TSDF authorized by the state of Utah Nuclear Regulatory Commission Agreement Rules. Envirocare of Utah currently provides licensed disposal capacity for low-level radioactive waste, $11 \mathrm{e}(2)$ waste, and mixed wastes. DOE has multiple disposal contracts available for use by generators seeking Envirocare of Utah disposal capacity. The DOE Oak Ridge Office manages the mixed low-level waste disposal contract. Envirocare's general WAC are based on the facility's current license, available at http://www.envirocareutah.com.

Commercial TSDFs are another commercial option for disposal of RCRA-hazardous, non-radiological waste only. Mixed wastes are not disposed at these facilities. Because of widespread radiological contamination and the co-mingling of radiological and RCRA contaminants, such as cesnium-137 and mercury in soil, it is unlikely that Y-12-contaminated soils would be certified for this type of commercial disposal.

\subsection{TRANSPORTATION REQUIREMENTS}

Soils are typically transported from the staging area in bulk, but contaminated soils may be containerized prior to off-site disposal to meet U. S. Department of Transportation and other regulatory requirements. Special manifesting, transporter licensing requirements, and record-keeping requirements apply to off-site transport of contaminated wastes. On-site transportation requirements (i.e., not on public roads) are less stringent; therefore, on-site transportation and disposal in ORR waste management units is the preferred option for disposition of contaminated soil.

Federal regulations for hazardous materials transportation are found at 49 CFR 100-185, "U. S. Department of Transportation Hazardous Materials Shipping regulations." Requirements for packaging, labeling, placarding, and shipping hazardous wastes and radiological material shipping are addressed in these regulations. RCRA hazardous waste manifesting requirements for generators are found at 40 CFR 262.20. For TSDFs, waste manifesting requirements are found at 40 CFR 264.71, 264.72, 264.76, 265.71, 265.72 , and 265.76 . 
TDEC requires that persons who transport radioactive waste or have radioactive waste transported into or within the state of Tennessee to a disposal/processing facility must obtain a License-for-Delivery from the Division of Radiological Health. The licensing process normally takes 6 to 8 weeks. Generators of radioactive waste have the primary responsibility to assure that a Tennessee License-for-Delivery is obtained before the waste is transported. 
04-120(E)/030205 


\section{REFERENCES}

DOE (U. S. Department of Energy) 1995. Remedial Investigation Report on Chestnut Ridge Operable Unit 2 (Filled Coal Ash Pond/Upper McCoy Branch) at the Oak Ridge Y-12 Plant, Oak Ridge, Tennessee, DOE/OR/01-1268/V1\&D2, Prepared by CDM Federal Programs, Inc.

DOE (U. S. Department of Energy) 1997. Report on the Remedial Investigation of Bear Creek Valley at the Oak Ridge Y-12 Plant, Oak Ridge, Tennessee, U. S. Department of Energy, Office of Environmental Management, Oak Ridge, Tennessee, DOE/OR/01-1455/V1\&D2, Lockheed Martin Energy Systems, Inc., Oak Ridge, TN.

DOE (U. S. Department of Energy) 1998. Report on the Remedial Investigation of the Upper East Fork Poplar Creek Characterization Area at the Oak Ridge Y-12 Plant, Oak Ridge, Tennessee, DOE/OR/01-1641/V1-V4\&D2, Bechtel Jacobs Company LLC, Oak Ridge, TN.

DOE (U. S. Department of Energy) 2001. Attainment Plan for Risk/Toxicity-Based Waste Acceptance Criteria at the Oak Ridge Reservation, Oak Ridge, Tennessee, DOE/OR/01-1909\&D3, Office of Environmental Management, Oak Ridge, TN.

DOE (U. S. Department of Energy) 2003a. Upper East Fork Poplar Creek Soil and Scrapyard Focused Feasibility Study. U. S. Department of Energy Office of Environmental Management, Oak Ridge, Tennessee, DOE/OR/01-2083\&D1, Bechtel Jacobs Company L.L.C., Oak Ridge, TN.

DOE (U. S. Department of Energy) 2003b. 2003 Remediation Effectiveness Report for the U. S. Department of Energy Oak Ridge Reservation, Oak Ridge, Tennessee. U. S. Department of Energy Office of Environmental Management, Oak Ridge, Tennessee, DOE/OR/01-2011\&D1, Bechtel Jacobs Company LLC, Oak Ridge, TN.

FFA (Federal Facilities Agreement) 1992. The U. S. Department of Energy's Oak Ridge Reservation Federal Facilities Agreement Under Section 120 of CERCLA, and Section 3008(h) and 6001 of RCRA, Docket No. 89-04-FF.

MMES (Martin Marietta Energy Systems, Inc.) 1984. Investigation of Subsurface Mercury at the Oak Ridge Y-12 Plant. ORNL/TM-9092, Oak Ridge National Laboratory, Oak Ridge, TN.

MMES (Martin Marietta Energy Systems, Inc.) 1989. Results of the Outdoor Radiological and Chemical Surface Scoping Survey at the Y-12 Plant Site. Y/TS-600, Oak Ridge Y-12 Plant, Oak Ridge, TN.

Radian Corporation 1993. Soil Management Plan for the Y-12 Plant, Y/SUB/92-28B99923C-Y05, Prepared for Lockheed Martin Energy Systems, Inc., Oak Ridge Y-12 Plant, Oak Ridge, TN, January.

Roy F. Weston, Inc., 1986. Pathways Analysis for the UNC Disposal Pit, Y-12 Plant, Y/SUB/86-22264/1, prepared for Martin Marietta Energy Systems, Inc., Oak Ridge, TN.

TDEC (Tennessee Department of Environment and Conservation) 2003. Tennessee Department of Environment and Conservation, Memorandum of Understanding between the Tennessee Division of Radiological Health and the Tennessee Division of Solid Waste Management, March 25. 
04-120(E)/030205 


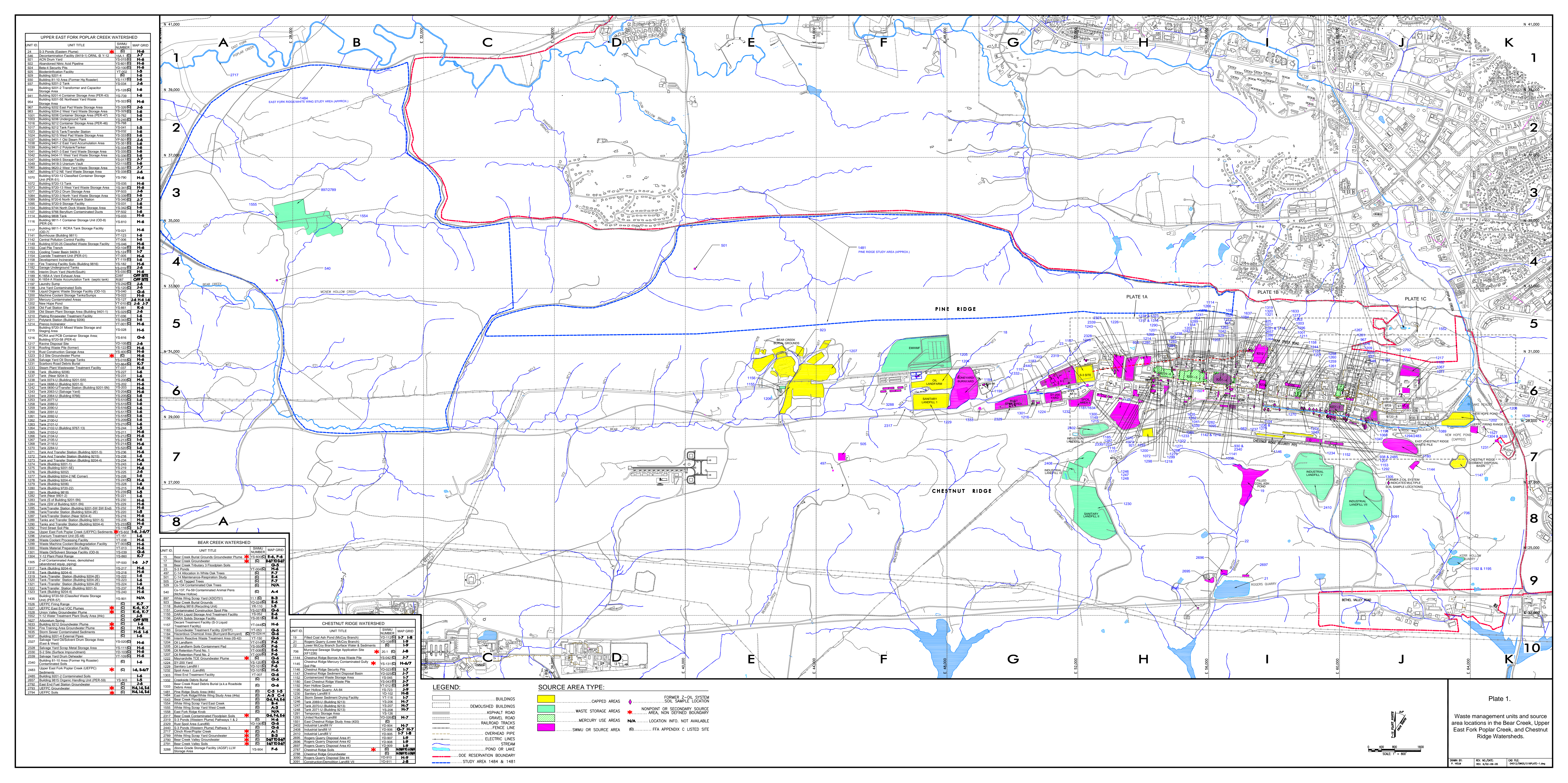


04-120(E)/030205 


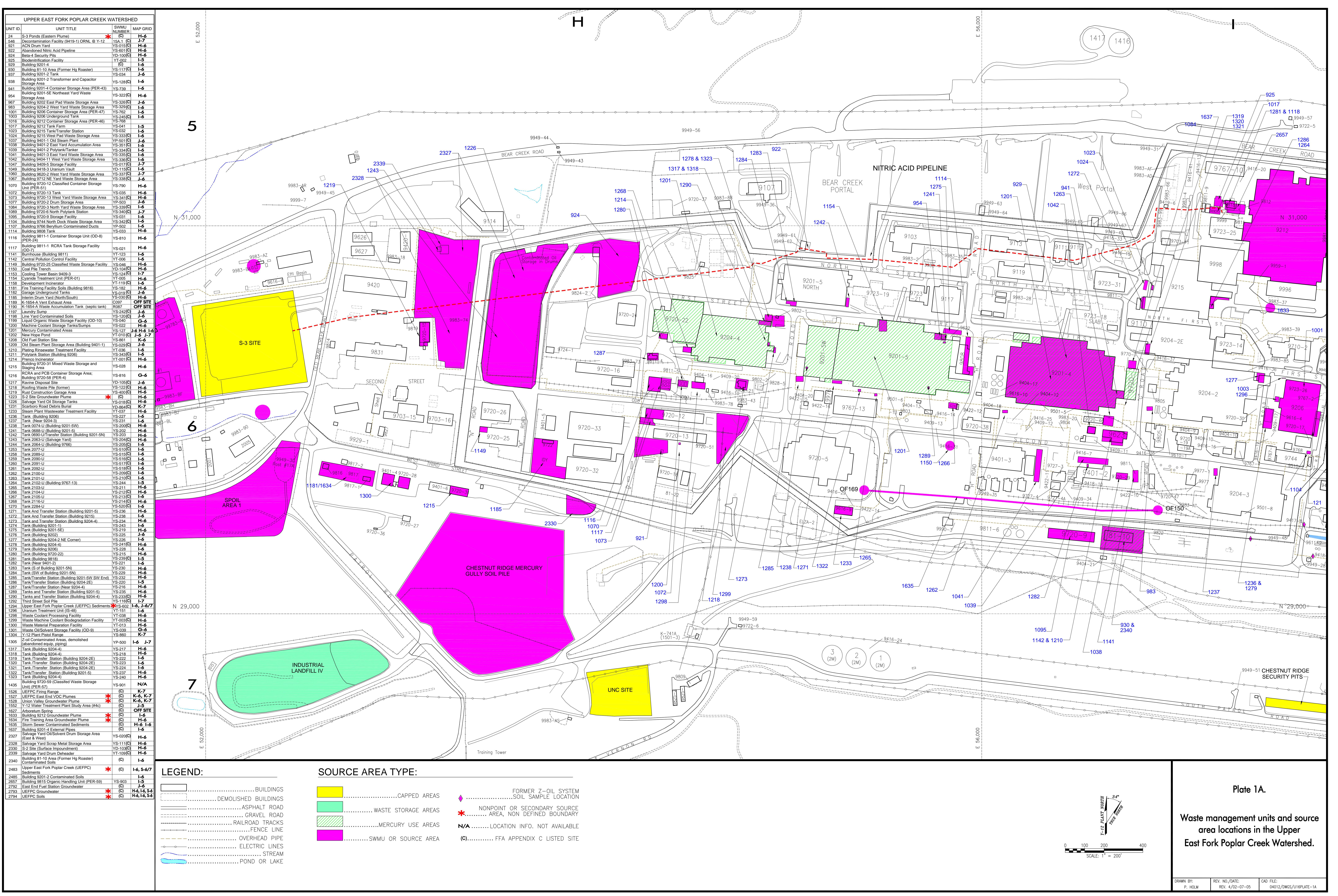


04-120(E)/030205 


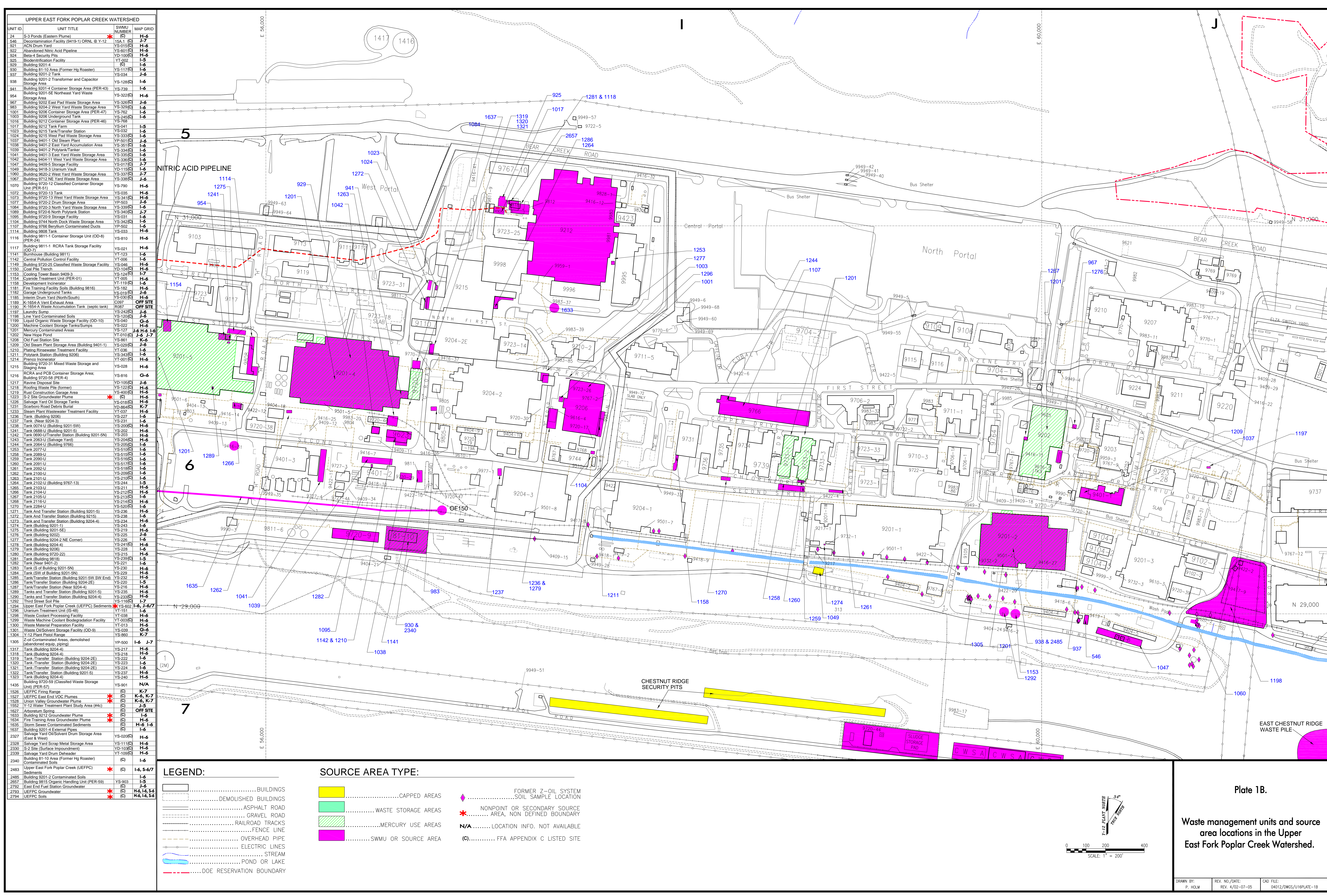


04-120(E)/030205 


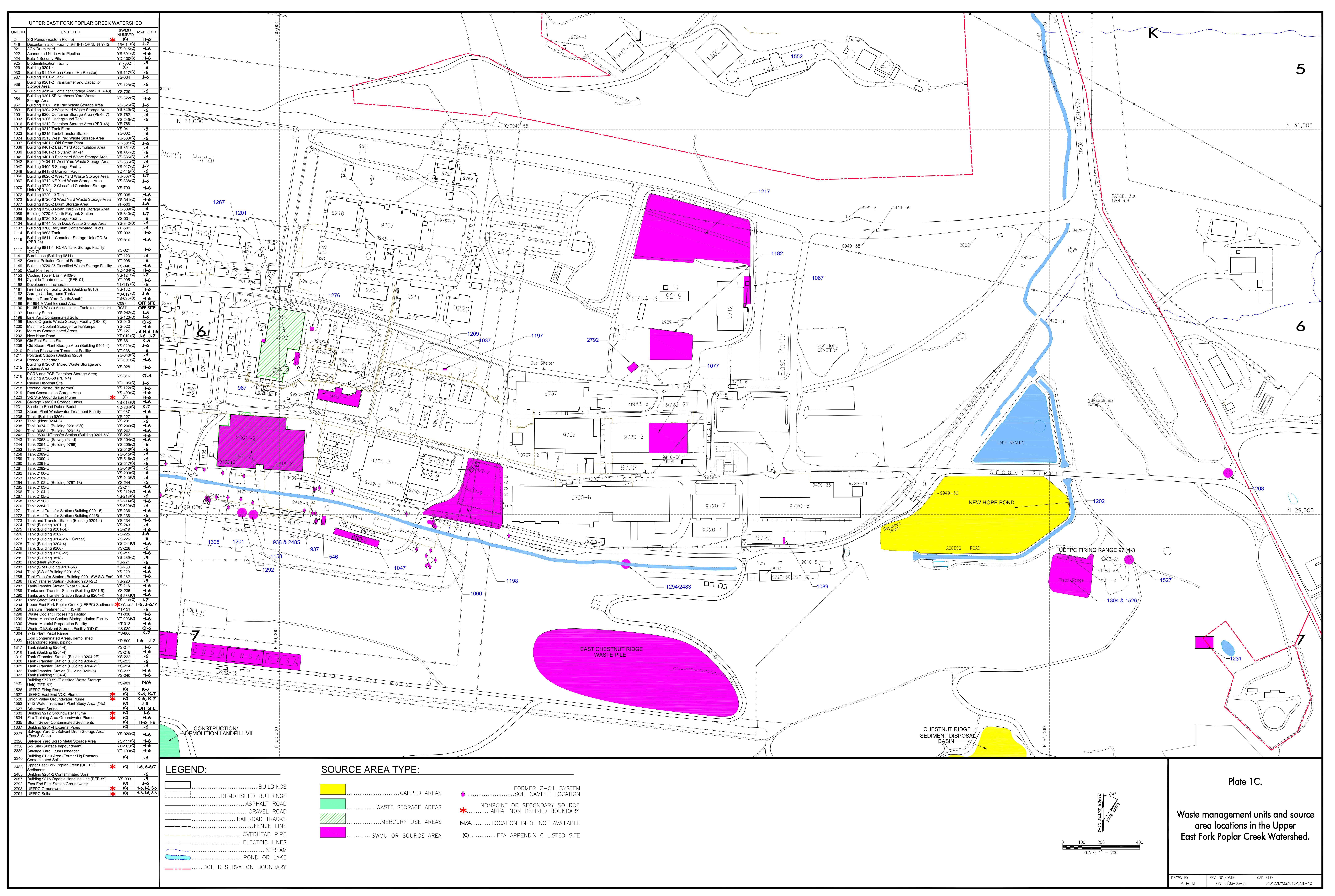


04-120(E)/030205 


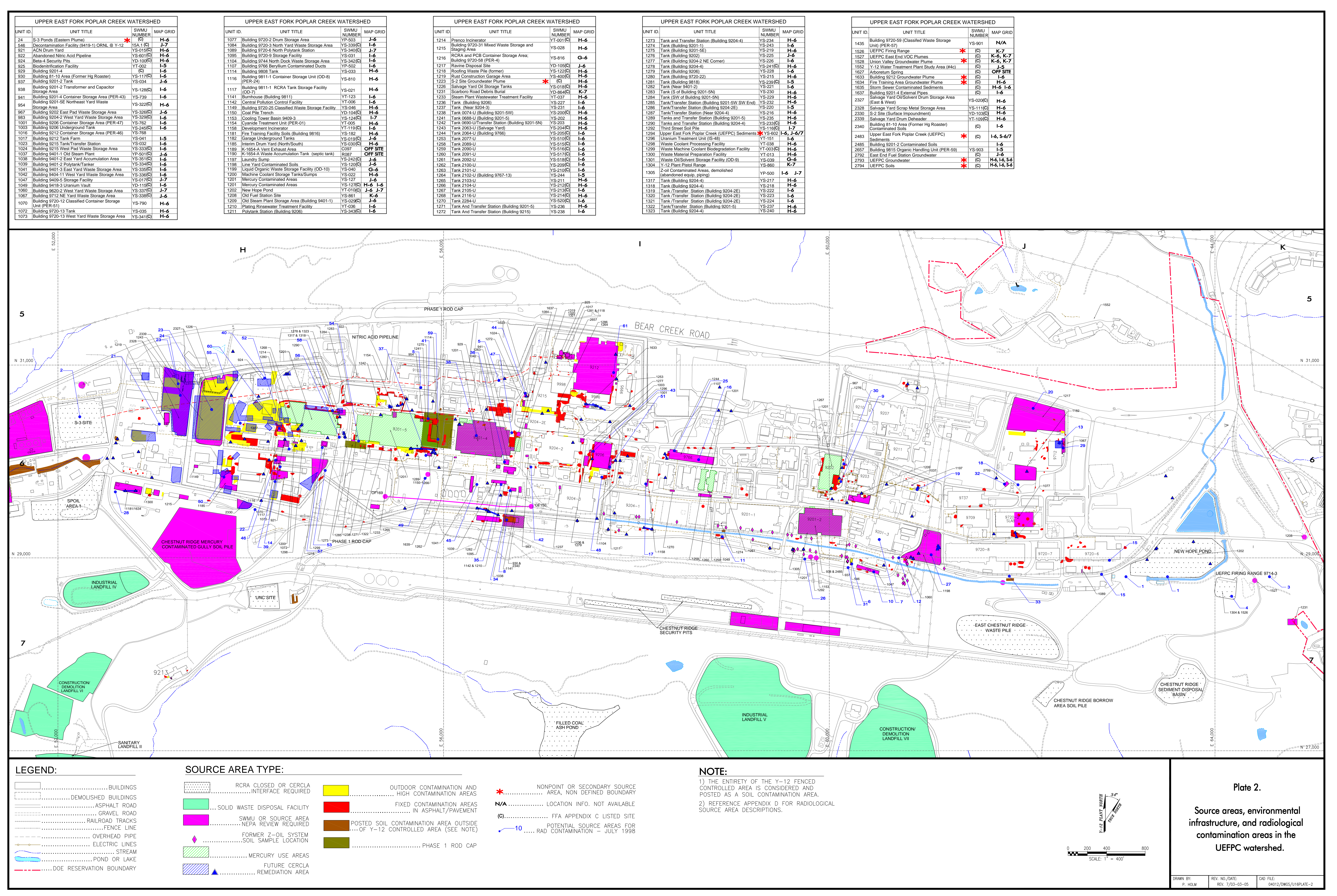


04-120(E)/030205 
APPENDIX A

BWXT Y-12, L.L.C.

NATIONAL ENVIRONMENTAL POLICY ACT

REVIEW PROJECT CHECKLIST 
04-120(E)/030205 


\section{BWXT Y-12, L.L.C. NEPA Review Project Checklist}

\section{ADMINISTRATIVE INFORMATION}

\begin{tabular}{|c|c|c|c|c|}
\hline \multicolumn{2}{|l|}{ Project Title: } & \multicolumn{2}{|c|}{ Charge No: } & Date: \\
\hline \multicolumn{2}{|l|}{ ESO, MJR or Other Project No: } & \multicolumn{3}{|c|}{ NEPA Needed By (Date): } \\
\hline \multicolumn{2}{|l|}{ Project Manager/Leader: } & \multicolumn{3}{|c|}{ Bldg/MS/Phone No: } \\
\hline Customer Organization: & Customer Contact (Name): & \multicolumn{3}{|c|}{ Bldg/MS/Phone No: } \\
\hline \multirow{3}{*}{\multicolumn{2}{|c|}{ Brief Statement of Project Scope: }} & \multicolumn{3}{|c|}{ Project Status: } \\
\hline & & Ongoing & Proposed & Revised \\
\hline & & \multicolumn{3}{|c|}{ Estimated Start Work Date: } \\
\hline
\end{tabular}

Project Location (Plant/Site, Area, Bldg No.):

\begin{tabular}{l|l|l|l|l||l|l|l|l|l}
\hline \hline \multicolumn{3}{l||}{ DOE/NNSA Program Office Providing Funding: } & \multicolumn{3}{l}{ Funding Category: } \\
\hline DP & NN & EM/WM & WFO & Other & LI & CE & GPP & EXP & GPE \\
\hline \hline
\end{tabular}

2. ENVIRONMENTAL SUMMARY: Would changes, disturbances and/or use occur within the following entities either during construction or operation? (details are requested in later sections.) $\quad \mathrm{Y}=\mathrm{Yes}, \mathrm{N}=\mathrm{No}, \mathrm{U}=$ Uncertain

1. Air Emissions

2. Liquid effluents

3. Solid waste

4. Soil

5. Radioactive waste

6. Hazardous waste

7. Mixed waste ( $\mathrm{rad}+\mathrm{haz})$

8. PCB waste

9. Asbestos waste

10. Classified waste

11. Chemical storage/use

12. Petroleum storage/use

13. Pesticide/herbicide use

14. Volatile/toxic/water reactives

15. Rad/haz substance exposure

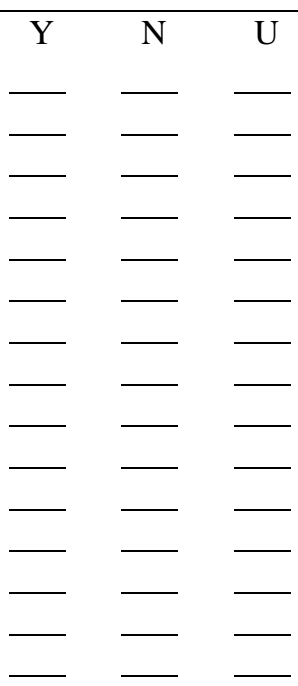

16. Floodplain/wetland interaction

17. Threatened and/or endangered species

18. Clearing or excavation

19. Archeological/cultural resources

20. Ozone-depleting substances

21. Explosives

22. Transportation issues

23. Elevated noise levels

24. Drinking water system

25. Sanitary sewage system

26. Storm drain system

27. Water use/diversion

28. PCB spill area

29. Steam piping modification

30. Other

Would the action require new or modifications to environmental permits?

If yes, identify. 
3. PURPOSE AND NEED FOR PROPOSED ACTION: State intention, purpose, and need for the action, and any pertinent background information. Include attachments where appropriate, such as Systems Requirements Document, Conceptual Design Report, etc.

4. LOCATION OF ACTION: Describe in detail the location at which the action would take place, and facilities/areas that would be impacted. Attach maps, site drawings, floor plans, sketches, and/or photographs, if available and relevant.

5. COMPONENTS OF PROPOSED ACTION: Describe the components of the project, including demolition, construction and operational phases. Be sure to include all support activities (e.g. decontamination, relocation of equipment, removal/addition of walls) and support facilities (e.g., utilities, access roads) required for the project. Include attachments where appropriate.

6. DESCRIPTION OF MATERIALS/WASTES: Describe the kinds and amounts of materials that would be used or brought on site and the wastes or excess materials that would be generated during both the C/D and operational phase. Include attachments where appropriate, such as the Waste Management Plan and lists of hazardous materials being brought on site along with a description of the applicable storage requirements (i.e., flammable storage cabinets, secondary containment, etc). (See also Section 9.)

Construction/Demolition:

Operations: 
7. POTENTIAL ENVIRONMENTAL IMPACTS: Would the action involve or affect any of the following?

\begin{tabular}{l|l|l|l|l}
\hline \hline & Y & N & U & \\
\hline Undeveloped areas & & & & \\
\hline $\begin{array}{l}\text { Threatened and/or endangered species } \\
\text { or potential habitat }\end{array}$ & & & & \\
\hline $\begin{array}{l}\text { Soil disturbance: excavation, } \\
\text { clearing, grading (>1 acre? }\end{array}$ & & & & \\
\hline 100- or 500-year floodplain & & & & \\
\hline Groundwater or surface waters & & & & \\
\hline Wetland area & & & & \\
\hline Air quality & & & & \\
\hline Natural resources (Energy consumption) & & & & \\
\hline Historic sites or properties & & & & \\
\hline $\begin{array}{l}\text { Located in Y-12 Plant National Register } \\
\text { Historic District }\end{array}$ & & & & \\
\hline $\begin{array}{l}\text { Archeological sites (undisturbed areas or } \\
\text { known sites) }\end{array}$ & & & & \\
\hline A building/structure or a portion thereof & & & & \\
\hline CERCLA remedial action area & & & & \\
\hline
\end{tabular}

$\mathrm{Y}=\mathrm{Yes}, \mathrm{N}=\mathrm{No}, \mathrm{U}=$ Uncertain 


\section{POTENTIAL FACILITY IMPACTS}

8.1 WATER RELATED SYSTEMS: Consider whether the action would involve the use of, discharges to, constructing or expanding the capacity of, or extending the useful life of systems such as wastewater treatment system, storm water drainage system, groundwater monitoring wells, etc. Discharges could include car wash rinse waters, cooling water discharges, stormwater runoff, etc.) Would the action involve, use, or affect:

\begin{tabular}{|c|c|c|c|c|}
\hline & $\mathrm{Y}$ & $\mathrm{N}$ & $\mathrm{U}$ & Describe \\
\hline \multicolumn{5}{|l|}{ Wastewater treatment system } \\
\hline \multicolumn{5}{|l|}{ Sanitary sewer system } \\
\hline \multicolumn{5}{|l|}{ Storm water drainage system } \\
\hline \multicolumn{5}{|l|}{$\begin{array}{l}\text { Potable, process, or fire water supply } \\
\text { system }\end{array}$} \\
\hline \multicolumn{5}{|l|}{ Groundwater monitoring wells } \\
\hline $\begin{array}{l}\text { Discharges to ground (e.g., condensate, } \\
\text { drain fields, french drains, or dry wells) }\end{array}$ & & & & \\
\hline
\end{tabular}

$\mathrm{Y}=\mathrm{Yes}, \mathrm{N}=\mathrm{No}, \mathrm{U}=$ Uncertain

[Y71-901, Dike Management and Contained Water Discharges]

[Y/TS-104R1, Environmental Standards for Primary and Secondary Containment and Transfer Stations]

[Y71-920, Modifications to Y-12 Storm Drain and Sanitary Sewer Systems]

8.2 DISTURBANCE OF HAZARDOUS/RADIOACTIVE SUBSTANCES: Consider whether the action would involve the disturbance of hazardous substances, pollutants, or contaminants that preexist at the project location. Would the action involve or affect:

\begin{tabular}{l|l|l|l|l}
\hline \hline & Y & N & U & \\
\hline Disturbance of hazardous substances & & & & \\
\hline $\begin{array}{l}\text { Disturbance of radioactive } \\
\text { contamination }\end{array}$ & & & & \\
\hline Contaminated groundwater & & & & \\
\hline $\begin{array}{l}\text { Solid Waste Management Units } \\
\text { (SWMU) }\end{array}$ & & & & \\
\hline
\end{tabular}

$\mathrm{Y}=\mathrm{Yes}, \mathrm{N}=\mathrm{No}, \mathrm{U}=$ Uncertain

Describe spill prevention precautions and controls this project will implement. 


\section{WASTE GENERATION AND HANDLING}

9.1 Solid/Liquid Wastes: Indicate solid, liquid, and/or sludge wastes that would be generated.

\begin{tabular}{l|l|c|c|c|c|c|c|c|c}
\hline \hline \multicolumn{1}{c}{ Waste Type (check all that apply) } \\
\hline $\begin{array}{c}\text { Waste } \\
\text { Stream }\end{array}$ & Rad & $\begin{array}{c}\text { RCRA } \\
\text { (Hazardous) }\end{array}$ & PCB & Mixed & $\begin{array}{c}\text { Sanitary/ } \\
\text { Industrial }\end{array}$ & Oil/Oily & Asbestos & $\begin{array}{c}\text { Scrap } \\
\text { Metals }\end{array}$ & Excess Soil \\
\hline Solid & & & & & & & & & \\
\hline Liquid & & & & & & & & & \\
\hline Sludge & & & & & & & & & \\
\hline
\end{tabular}

If solid, liquid, and/or sludge wastes will be generated, either during construction or subsequent operation, estimate the quantity below and describe the means by which they would be managed. Attach additional information as appropriate.

Waste Management Forecast (estimate amounts in appropriate box)

\begin{tabular}{l|c|c|c|c|}
\hline $\begin{array}{c}\text { Waste } \\
\text { Stream }\end{array}$ & $\begin{array}{c}\text { Tankers/Tanks/ } \\
\text { Containers }\end{array}$ & $\begin{array}{c}\text { Discharge into } \\
\text { Storm Drain }\end{array}$ & $\begin{array}{c}\text { Discharge into } \\
\text { Sanitary Sewer }\end{array}$ & $\begin{array}{c}\text { Landfill } \\
\text { or Other }\end{array}$ \\
\hline Solid & & & & \\
\hline Liquid & & & & \\
\hline Sludge & & & & \\
\hline
\end{tabular}

Has a Waste Disposition path been identified?

If not, describe needs.

\subsection{Air Emissions:}

Would the action generate airborne emissions during construction?

During operation?

Will there be airborne emissions other than nitrogen, oxygen, compressed air, or water vapor?

If YES, describe materials involved, types of emissions (particulate, gaseous, etc.) and estimate amounts:

\begin{tabular}{c|c|c}
\hline \hline Material & Type of Emission & Amount \\
\hline & & \\
\hline & & \\
\hline & & \\
\hline
\end{tabular}

What types of control equipment or administrative controls would be used to mitigate airborne emissions? 


\section{POLLUTION PREVENTION/WASTE MINIMIZATION:}

This section involves incorporation of pollution prevention/waste minimization principles into the action to reduce or eliminate liquid, solid, or gaseous wastes, or use recycled content materials per Y71-311INS, Y-12 Pollution Prevention Program Implementation Instruction, and others listed below. Please consider all options.

Would the action involve any of the following:

\begin{tabular}{l|l|l|l|l}
\hline \hline \multicolumn{1}{c|}{ 10.1 Source reduction activities } & Y & N & NA & \\
\hline Substitute less hazardous input materials & & & & \\
\hline $\begin{array}{l}\text { Improve operating practices (e.g., volume } \\
\text { reduction, best management practices) }\end{array}$ & & & & \\
\hline $\begin{array}{l}\text { Select environmentally friendly (less toxic) } \\
\text { or longer life products }\end{array}$ & & & & \\
\hline $\begin{array}{l}\text { Implement process/technology changes } \\
\text { (e.g., equipment modifications) }\end{array}$ & & & & \\
\hline
\end{tabular}

\begin{tabular}{l|l|l|l|l}
\hline \hline \multicolumn{1}{c|}{ 10.2 Recycling activities } & Y & N & NA & \\
\hline $\begin{array}{l}\text { Implement in-process recycling } \\
\text { (e.g., solvent recovery) }\end{array}$ & & & & \\
\hline $\begin{array}{l}\text { Re-use surplus materials on-site } \\
\text { (e.g., chemical exchange) }\end{array}$ & & & & \\
\hline $\begin{array}{l}\text { Recycle materials off-site (e.g., scrap } \\
\text { metal, fluorescent bulbs, used oil) }\end{array}$ & & & & \\
\hline
\end{tabular}

[ Y71-177, Y-12 Complex Wide Recycling ]

\begin{tabular}{l|l|l|l|l}
\hline \hline 10.3 Affirmative procurement activities & Y & N & NA & Describe \\
\hline $\begin{array}{l}\text { Buy materials with recycled contents } \\
\text { (e.g. concrete, insulation, office supplies) }\end{array}$ & & & & \\
\hline $\begin{array}{l}\text { Purchase energy and water efficient } \\
\text { equipment }\end{array}$ & & & & \\
\hline $\begin{array}{l}\text { Segregate waste/material types } \\
\text { (e.g. hazardous, rad, sanitary) }\end{array}$ & & & & \\
\hline
\end{tabular}

[ Y71-938INS, Y-12 Affirmative Procurement Instruction ]

$\mathrm{Y}=\mathrm{Yes}, \mathrm{N}=\mathrm{No}, \mathrm{NA}=$ Not applicable

NOTE: All waste generation, air emissions, water discharges, and other impacts to the human environment should be As Low As Reasonably Achievable (ALARA)!!

Revised 5/25/04 


\section{APPENDIX B}

SOURCE AREA SUMMARY INFORMATION FROM

REMEDIAL ACTION INFORMATION MANAGEMENT SYSTEM (RAIMS) 
04-120(E)/030205 
Table B.1. Source area summary information from Remedial Action Information Management System (RAIMS)

\begin{tabular}{|c|c|c|c|c|c|c|}
\hline $\begin{array}{l}\text { Unit ID } \\
\text { number }\end{array}$ & Unit title & $\begin{array}{l}\text { Unit location } \\
\text { description }\end{array}$ & History & $\begin{array}{c}\text { CERCLA } \\
\text { FFA status }\end{array}$ & SWMU note & $\begin{array}{l}\text { SWMU HSWA } \\
\text { permit } \\
\text { appendix } \\
\text { classification }^{a}\end{array}$ \\
\hline
\end{tabular}

\section{Upper East Fork Poplar Creek Watershed}

24 S-3 Ponds The S-3 Ponds are The former S-3 Ponds Waste Management Area (S-3 Ponds), now

(Eastern Plume) located in the closed and capped, were used for disposal of acidic mixed waste. western end of the

Y-12 NSC. A

portion of the

groundwater

contamination

extends into the

UEFPC CA.

546 Decontamination Located in the Facility (9419-1) southeast section \{ORNL@Y-12\} of the Y-12 NSC, south of UEFPC, north of Third

Street and adjacent to Bldg. 9409-5

ACN Drum Yard Southwest of Bldg. 9720-13 and northwest of Bldg. 9720-18.
Drums of ACN were stored outdoors on pallets before being processed through the Prenco Incinerator. The drums were removed to the Interim Drum Yard (YS-030) in January 1985, then the yard was paved with asphalt. There is no evidence of leakage from ACN drums. The site was RCRA clean closed with confirmatory soil sampling in 1987 and categorized as requiring no further action by EPA. Before its use as a drum yard, this area was used to store equipment associated with an adjacent maintenance building. $\begin{array}{lll}\text { The DFB, built in 1958, was used to remove contaminants such as Demolished Rad only; } \\ \text { beryllium from equipment associated with development of the } & \text { in 1998; } & \text { CERCLA D\&D }\end{array}$

molten-salt reactors. The primary method of decontamination was facility slab

through steam cleaning. Operations stopped with the end of the MSRP in 1969; the Building was used for storage until 1976.

to be addressed in

future

UEFPC

ROD.

\section{RCRA RCRA clean}

Clean closure 10/87

Closure in

1987
Historical 


\begin{tabular}{|c|c|c|c|c|c|c|}
\hline $\begin{array}{l}\text { Unit ID } \\
\text { number }\end{array}$ & Unit title & $\begin{array}{c}\text { Unit location } \\
\text { description }\end{array}$ & History & $\begin{array}{c}\text { CERCLA } \\
\text { FFA status }\end{array}$ & SWMU note & $\begin{array}{l}\text { SWMU HSWA } \\
\text { permit } \\
\text { appendix } \\
\text { classification }^{a}\end{array}$ \\
\hline 922 & $\begin{array}{l}\text { Abandoned Nitric } \\
\text { Acid Pipeline }\end{array}$ & $\begin{array}{l}\text { UEFPC } \\
\text { watershed; } \\
\text { between } \\
\text { Bldgs. } 9212 \text {, } \\
\text { 9215, } 9206 \text { and } \\
\text { S-3 Ponds }\end{array}$ & $\begin{array}{l}\text { This pipeline was installed in } 1951 \text { to transport liquid wastes } \\
\text { from buildings } 9212,9215 \text {, and } 9206 \text { to the S-3 Ponds. In } 1983 \text {, } \\
\text { the pipeline was plugged with cement grout and abandoned. } \\
\text { During the mid-1980s, sections of the pipeline were removed } \\
\text { during various construction projects. Remedial Investigation field } \\
\text { activities evaluated soils for metals, nitrate/nitrite, and isotopic } \\
\text { uranium. Samples from three boreholes were also analyzed for } \\
\text { volatile organic compounds. }\end{array}$ & $\begin{array}{l}\text { NFA } \\
\text { approved } \\
9 / 94\end{array}$ & $\begin{array}{l}\text { Waste line; } \\
\text { CERCLA NFA } \\
\text { ROD 9/94 }\end{array}$ & A-2 \\
\hline 924 & $\begin{array}{l}\text { Beta-4 Security } \\
\text { Pits }\end{array}$ & $\begin{array}{l}\text { At the west end of } \\
\text { Y-12, next to } \\
\text { Bldg. 9824-1 }\end{array}$ & $\begin{array}{l}\text { This site was used to dispose of classified waste from } \\
\text { February } 1968 \text { to April 1976, including uranium and uranium } \\
\text { alloys, depleted and enriched uranium-contaminated metal, } \\
\text { aluminum, steel, magnesium, beryllium, organic compounds, } \\
\text { acids, and miscellaneous waste debris. In general, the } 170-\mathrm{ft} \\
\text { trenches, one opened in February } 1968 \text { and the other opened in } \\
\text { June } 1971 \text {, were used for metal components. The } 45-\mathrm{ft} \text { trench, } \\
\text { opened in November 1971, was used for burnable materials such } \\
\text { as honeycomb, although no burning occurred. The } 14-\mathrm{ft} \text { trench } \\
\text { was used for a one-time disposal of } 7.97 \text { tons of tungsten alloy } \\
\text { parts on May } 30,1972 \text {. There are no documented releases from } \\
\text { this site. Based on sampling conducted during the PA, it was } \\
\text { concluded that "the Beta- } 4 \text { Security Pits do not show evidence of } \\
\text { leakage to the groundwater nor to the surface water and soils } \\
\text { immediately adjacent to the site" (Y/TS-266, Supp. 1). }\end{array}$ & & $\begin{array}{l}\text { Rad-contaminat } \\
\text { ed solid waste } \\
\text { burial ground }\end{array}$ & A-1(a) \\
\hline 925 & $\begin{array}{l}\text { Biodenitrification } \\
\text { Facility }\end{array}$ & $\begin{array}{l}\text { South of 9404-22 } \\
\text { and adjacent to } \\
\text { Bldg. } 9818\end{array}$ & & & $\begin{array}{l}\text { CWA } \\
\text { Permit-by-rule }\end{array}$ & A-2 \\
\hline 929 & Building 9201-4 & $\begin{array}{l}\text { South of First } \\
\text { Street, between } \\
\text { "G" and "H" roads } \\
\text { at Y-12 }\end{array}$ & $\begin{array}{l}\text { From } 1945 \text { to } 1947,9201-4 \text {, known as Alpha- } 4 \text {, was used to } \\
\text { enrich uranium through the electromagnetic separation process. } \\
\text { In } 1947 \text { the enrichment process was placed on standby mode, and } \\
\text { only routine Building maintenance occurred. In } 1953 \text {, the } \\
\text { uranium process equipment was removed and replaced with }\end{array}$ & $\begin{array}{l}\text { Outside } \\
\text { piping } \\
\text { Removal } \\
\text { action } \\
\text { complete }\end{array}$ & & \\
\hline
\end{tabular}


930 Building 81-10 East of 9720-9 Area $\{$ Former $\mathrm{Hg}$ and south of Roaster\}
Unit location description
SWMU HSWA

permit

appendix

CERCLA

FFA status SWMU note

classification $^{a}$

COLEX process equipment, used to separate the Lithium-6

isotope from natural assay lithium. No decontamination of the

facility was performed prior to installing the COLEX equipment, 9/29/99);

which began operation in 1955. The COLEX process used large

quantities (more than 10 million $\mathrm{kg}$ ) of elemental mercury for the ongoing.

lithium separation process. Numerous mercury spills and leaks

are known to have occurred. In 1962, the lithium separation

process in Alpha-4 was shut down, and most of the process liquid was drained from the system. While other activities were

conducted within various parts of the building, the COLEX

process equipment remained on standby. Mercury recovery

activities began in 1983. Initial efforts recovered an estimated

$45,000 \mathrm{~kg}$ of mercury through breaking pipe flanges or

disconnecting equipment. The COLEX equipment, however, was not dismantled and remains relatively intact on the site. During operation of the COLEX process, a pipe that passed over Second Street supplied hydrogen from a cascade in Alpha-4 to a furnace in Bldg. 9727-3. The hydrogen contained trace quantities of mercury vapor that condensed in the pipe and collected at low points along the pipe route. On June 7, 1995, about $6 \mathrm{~kg}$ of mercury leaked out of the pipe, and a total of $14 \mathrm{~kg}$ of mercury was recovered during pipe removal. The mercury was subsequently cleaned up, and a 6-meter section of the hydrogen pipe was removed where it passes over Second Street. site was identified as a tin shop in early Y-12 Plant maps. In 1957 a roasting furnace was located on the site. This site has been used as a mercury recovery facility since 1957 . The site has also stored
Demolished Building remov in 1995; $\quad$ ed in 1995; removal Former Hg soil action storage
Building 81-10 was located south of UEFPC on the original creek channel. Included as part of the site is a sump (Bldg. 9822) on the east side of "G" Road. The Bldg. 81-10 sump drains into UEFPC where the creek flows through an underground 90-in. reinforced concrete pipe. Building 81-10 was built in 1943. This

A-1(a) original creek channel complete. 
mercury- contaminated soil. A furnace was used to recover mercury from sludges, wastes, contaminated soil, scrap from dismantled equipment, and other similar materials used at the Y-12 Plant in the late 1950s and early 1960s. During operation of the furnace, it is estimated that $1361 \mathrm{~kg}$ of mercury were spilled on the concrete pad, beneath the concrete pad, and on the ground. In 1984, the site was used as a storage area to stockpile mercury-contaminated soil. The soil was removed at an unknown date. Building 81-10 and its sump were cleaned in 1971,

including the transfer of sludge to drums. During cleaning, an estimated total of $91,451 \mathrm{~kg}$ of mercury was removed from the contaminated materials in the Bldg. 81-10 area with $1209 \mathrm{~kg}$ of the total mercury being removed from the sump. Of the mercury removed, $32,270 \mathrm{~kg}$ were recovered and the rest was disposed of as scrap. In a memorandum from Ralph Turner to Don Borman on November 21, 1986, it was speculated that the area northeast of Bldg. 81-10 was the site of a springhouse. There is a layer of asphalt or concrete 15 to $20 \mathrm{ft}$ beneath the present grade, with an overburden of contaminated fill.

Poplar Creek and

southeast of

Bldg. 9610-2 


\begin{tabular}{|c|c|c|c|}
\hline $\begin{array}{l}\text { Unit ID } \\
\text { number }\end{array}$ & Unit title & $\begin{array}{l}\text { Unit location } \\
\text { description }\end{array}$ & History \\
\hline 938 & $\begin{array}{l}\text { Building 9201-2 } \\
\text { Transformer and } \\
\text { Capacitor Storage } \\
\text { Area }\end{array}$ & $\begin{array}{l}\text { Inside } \\
\text { Building 9201-2 } \\
\text { at Y-12 }\end{array}$ & $\begin{array}{l}\text { The site is a staging area inside Bldg. 9201-2, which houses } \\
\text { cyclotron cubicles. There were } 143 \text { PCB transformers and } 360 \\
\text { capacitors with an estimated PCB concentration greater than } \\
500 \text { ppm ( } \sim 3000 \text { gal of oil). Six major sumps are located in the } \\
\text { Building and discharge into Outfalls } 63 \text { and 55. These sumps are } \\
\text { part of the Mercury Abatement Report (Y/ER-251). } \\
\text { Building } 9201-2 \text { houses a variety of surplus ORNL equipment } \\
\text { that was either contaminated with PCBs or that contained } \\
\text { PCB-contaminated oils. At the staging area, transformers and } \\
\text { capacitors were drained and triple-rinsed with kerosene before } \\
\text { being moved outdoors. All surplus PCB- contaminated } \\
\text { transformers and capacitors have been disposed of in accordance } \\
\text { with TSCA regulations. Dates of operation are unknown. No } \\
\text { releases have been documented. The process-related constituents } \\
\text { are oils and PCBs. }\end{array}$ \\
\hline
\end{tabular}

941 Building 9201-4 Building 9201-4,
Container
Storage Area
Southeast
(PER-43)
Switchgear Room,

Building 9201-5E Northeast corner Northeast Yard

Waste Storage of Bldg. 9201-5E

Area

$$
\text { at } \mathrm{Y}-12
$$

967 Building 9202

East Pad Waste

Storage Area
Between buildings
9202 and 9205 at
Y-12

The paved storage area has been operational since 1983 as a container accumulation area used for the storage of

beryllium-contaminated solvents, uranium-contaminated liquids, and used oils.

The YS-326 site is a container accumulation area located between Bldgs. 9202 and 9205 . The area is a $30-$ by $90-\mathrm{ft}$ sealed concrete pad with five, connected, covered, metal storage bins and a drum storage area. Waste storage volume is six drums. The concrete pad was repaired in 1988 because of scaling and cracking. A metal roof was constructed over the area in 1988 as
SWMU HSWA

permit

appendix

CERCLA

FFA status

Will be Used for PCB

addressed

in UEFPC

Soils and

Scrapyard

ROD

storage

classification $^{a}$

Historical

RCRA permit

(TNHW 083)

certified clean

closure

Will be

addressed

Includes former

RCRA 90-day

in UEFPC accumulation

Soils and area

Scrapyard

ROD

Includes

historical waste

storage; and

former 90-day

AA;(AA-31)
A-2

Historical

Historical 


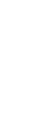

\begin{tabular}{l}
$\begin{array}{c}\text { Unit ID } \\
\text { number }\end{array}$ Unit title $\quad \begin{array}{c}\text { Unit location } \\
\text { description }\end{array}$ \\
\hline
\end{tabular}

well. The East Pad has operated since 1957 as a less-than-90-day accumulation area for miscellaneous laboratory chemicals, uranium-contaminated trash, and beryllium-contaminated trash. No releases have been document

983 Building 9204-2 West of 9204-2, West Yard Waste in UEFPC

Storage Area drainage basin $\mathrm{G}$ at $\mathrm{Y}-12$

1001 Building 9206 Building 9206,

Container First and Second

Storage Area Floor

Tank

\section{At HF scrub} solution structure at northwest
This area has been used to store sludge, mineral oil, and various drummed production wastes. Drums are stored on wooden

pallets. There have been no documented releases. corner of 9206, Subbasin $\mathrm{F}$ at Y-12
This UST was discovered in May or June 1987 during the construction work at Bldg. 9206. The tank was below grade underneath a concrete wall that had apparently been poured directly onto the tank. The tank was located in an area $\sim 25$ by $5 \mathrm{ft}$. Piping associated with the tank consisted of a vertical vent pipe, previously filled with concrete, that extended into the concrete wall, and inlet and outlet openings that had been plugged. The tank was removed by excavating the overlying asphalt and concrete. The tank was removed intact and set aside at the site. The tank contents consisted of sludge sampled through six holes, with $2 \mathrm{ft}$ separating each hole, drilled in the top of the tank. The tank was covered at the site while the contents were analyzed. After analysis the contents of the tank were removed and transported in polyethylene tanks for treatment and disposal. The tank was cut apart on the construction site and transported to the salvage yard on or about August 17, 1987. There were no apparent waste containment practices for this site (i.e., secondary containment or leachate collection system). Building 9206 operations include recycling and recovery of uranium. The tank
SWMU HSWA

permit

appendix

CERCLA

FFA status

SWMU note
Includes

historical drum

waste storage

RCRA permit

(TNHW-084)

Pulled in 1987;

contained

sludge cont. U

and metals
Historical 


洒

\begin{tabular}{l}
$\begin{array}{c}\text { Unit ID } \\
\text { number }\end{array}$ Unit title \\
\hline
\end{tabular}

SWMU HSWA

permit

appendix

History

received hydrogen fluoride scrub solution from Bldg. 9206. The
residual sludge in the tank contained uranium and metals. There are no documented releases; however, the presence of liquids, long period of operation, and lack of groundwater and soil data make the extent of possible releases uncertain.

1016 Building $9212 \quad$ Building 9212,

Container First and

Storage Area Mezzanine Level

(PER-46)

1017 Building $9212 \quad$ West of

Tank Farm Bldg. 9999

1023 Building 9215 West side of

Tank/Transfer Building 9215

1024 Building 9215

Storage Area Subbasin G at

$\mathrm{Y}-12$

Drive

which was formerly a Building foundation and is now used for

container accumulation of $8250 \mathrm{gal}$ of material. The site is sloped and surrounded by a curb. Building 9215 contains the H-1

Foundry and a rolling mill and machining operation for depleted and enriched uranium. This area has been used since 1955 for the accumulation of containers of used oil and miscellaneous scrap metal (including uranium). There are no documented releases from this site and the secondary containment makes it unlikely any releases occurred.

A $3500-\mathrm{ft}^{2}$ portion of the old steam plant was used for storage of laboratory chemicals and waste oils. In 1984 the facility stopped receiving waste. The west end of the Building is YS-029, which was clean closed under RCRA in 1986. No releases have been documented. active office

space
RCRA permit

(TNHW-084)

CWA

Permit-by-rule;

tank emptied

CWA

Permit-by-rule

Scrap metal and waste oil

storage

\section{Historical}

Ref. YS-029;

Historical 


\begin{tabular}{|c|c|c|c|c|c|c|}
\hline $\begin{array}{l}\text { Unit ID } \\
\text { number }\end{array}$ & Unit title & $\begin{array}{c}\text { Unit location } \\
\text { description }\end{array}$ & History & $\begin{array}{c}\text { CERCLA } \\
\text { FFA status }\end{array}$ & SWMU note & $\begin{array}{c}\text { SWMU HSWA } \\
\text { permit } \\
\text { appendix } \\
\text { classification }^{a}\end{array}$ \\
\hline 1038 & $\begin{array}{l}\text { Building 9401-2 } \\
\text { East Yard } \\
\text { Accumulation } \\
\text { Area }\end{array}$ & $\begin{array}{l}\text { East of } 9401-2 \text {, in } \\
\text { UEFPC } \\
\text { Subbasin E at } \\
\text { Y-12 }\end{array}$ & $\begin{array}{l}\text { This site has been used since } 1955 \text { for storing drums containing } \\
\text { spent plating solutions and sludges. The source of the wastes are } \\
\text { the process tanks in Bldg. } 9401-2 \text { that are periodically emptied of } \\
\text { their spent solutions. Sludges remaining in the tanks are manually } \\
\text { shoveled into drums. The volume of waste generated each month } \\
\text { is } \sim 55 \text { gal. The site was originally soil/gravel but was paved at an } \\
\text { unknown date. }\end{array}$ & $\begin{array}{l}\text { NFA } \\
\text { approved } \\
9 / 92\end{array}$ & $\begin{array}{l}\text { Former RCRA } \\
\text { 90-day } \\
\text { accumulation } \\
\text { area; rad waste } \\
\text { storage; } \\
\text { CERCLA NFA } \\
\text { ROD 9/30/92; } \\
\text { ref. YS-334 }\end{array}$ & Historical \\
\hline 1039 & $\begin{array}{l}\text { Building 9401-2 } \\
\text { Polytank/Tanker }\end{array}$ & $\begin{array}{l}\text { At Bldg. 9401-2, } \\
\text { in UEFPC } \\
\text { Subbasin E at } \\
\text { Y-12 }\end{array}$ & $\begin{array}{l}\text { This site is a 156- by } 30 \text {-ft paved pad on which three } 600 \text {-gal } \\
\text { aboveground polytanks are mounted. This area has received and } \\
\text { stored wastes from Bldg. } 9401-2 \text { plating activities since } 1983 \text {. } \\
\text { The Plating Shop Container Areas have been used since } 1983 \text { for } \\
\text { the collection of waste solutions and sludges that are generated } \\
\text { from metal-plating operations and processes. These waste } \\
\text { solutions contain hydrochloric, nitric, and hydrofluoric acids; } \\
\text { nickel solutions; copper and chrome plating wastes; cyanide; and } \\
\text { rinse waters. The cyanide and rinse waters are collected } \\
\text { separately from the other wastes. The waste solutions are } \\
\text { periodically transferred from metal processing tanks inside } \\
\text { Bldg. } 9407-2 \text { to } 600 \text {-gal polytanks and drums located in areas } \\
\text { along the north/northeast edge of Bldg. } 9401-2 \text { and the north side } \\
\text { of Bldg. } 9720-29 \text {. The polytanks and drums are temporarily } \\
\text { stored in these areas before shipment to waste treatment facilities. } \\
\text { During transfer of the waste solutions, incidental spills and } \\
\text { subsequent releases to the soil have occurred. A waste volume of } \\
\text { three to four polytanks is generated each month. There are } \\
\text { documented releases from this site resulting from the transfer of } \\
\text { waste solutions. }\end{array}$ & $\begin{array}{l}\text { NFA } \\
\text { approved } \\
9 / 92\end{array}$ & $\begin{array}{l}\text { RCRA 90-day } \\
\text { accumulation } \\
\text { areas (AA-17 } \\
\text { and AA-42); } \\
\text { CERCLA NFA } \\
\text { ROD 9/30/92; } \\
\text { ref. YS-351 }\end{array}$ & Historical \\
\hline
\end{tabular}


1042 Building 9404-11 West of 9404-11 West Yard Waste in UEFPC Storage Area Subbasin G at $\mathrm{Y}-12$

\section{Building 9409-5 South side of} Storage Facility UEFPC,

Subbasin A at Y-12
SWMU HSWA

permit

appendix

CERCLA
FFA status

History

Will be

$\begin{array}{ll}\text { containerized waste. The site slopes to the east toward a 36-in. } & \text { addressed } \\ \text { storm sewer west of Bldg. 9727-3. An 8-in. sanitary sewer } & \text { in UEFPC }\end{array}$

crosses under this area, flowing to the north. This site has been in Soils and operation since 1955 . The area has stored wastes generated as a Scrapyard result of operations associated with the steam plant

(Bldg. 9401-3), including oils (possibly contaminated with

PCBs), PCE, solvents, and mineral spirits. Uranium

contamination of the wastes is also possible. The east yard was paved at an unknown date, but spills may have occurred before the paving operation. There are no documented releases from this site; however, the presence of organics in surface soil samples makes it likely that spills have occurred.

Historical

This site has been used since 1976 as a less-than-90-day Will be accumulation area for the storage of drums containing acetonitrile addressed and wash water. There are no documented releases from this site

in UEFPC

Soils and

Scrapyard

ROD

Includes former

90-day

accumulation

area (AA-11);

historical

storage

Originally this site was a cooling tower serving Bldg. 9401-3. RI/FS in

This source area now consists of a concrete pad and a dike that at progress

RCRA clean

closed; 19968

tanks removed;

one time enclosed two 10,000-gal tanks, two 30,000-gal tanks, and four 5,700-gal tanks. The diked area is 241 by $33 \mathrm{ft}$ with a 6-ft-high dike. The tanks have been removed. From 1980 to 1989, also PCB the four larger tanks stored waste oils and solvents, mixed with

storage (TS-07)

Historical

miscellaneous chlorinated solvents. The four smaller tanks stored $\mathrm{m}$-wing coolant from 1985 to 1989 . The m-wing coolant contained PCE. All tanks have been removed and the area has been clean closed per RCRA requirements. There have been documented releases and the containment dike has failed leak tests. A report issued summarizing some limited soil sampling at

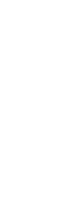


1060 Building 9620-2 At 9620-2, West Yard Waste Subbasin A at Storage Area Y-12

1067 Building 9712 NE Yard Waste Storage Area Subbasin $\mathrm{K}$ at

\section{Unit location} description
CERCLA

FFA status

SWMU HSWA

permit

appendix classification $^{a}$

the site recommended no further action (Y/TS-545, Energy Systems 1989).

1049 Building 9418-3 Subsurface; on the $\begin{array}{ll}\text { Uranium Vault } & \text { south side of } \\ \text { UEFPC west }\end{array}$ Bldg. 9404-1

This facility was originally used as a containment structure for a Z-Oil coolant storage tank (2072-U). In 1960 the

Building became a nonenriched uranium oxide $\left(\mathrm{U}_{3} \mathrm{O}_{8}\right)$ disposal facility. Drums of uranium oxide were emptied into the vault through manholes. When the vault was as full as possible, the manholes were filled with concrete. The material was considered "in storage" until 1964 when the vault was officially designated as a disposal unit. It is estimated that 238 metric tons of uranium oxide was placed in the vaults. No releases have been documented.

The West Yard is an undiked concrete pad. The surrounding site is graveled and slopes gently toward UEFPC. The area has operated from 1955 to the present as an accumulation area for used Z-oil. The used oil may have contained PCBs. The date of paving is unknown. No releases have been documented.

Will be addressed

in UEFPC Soils and

Scrapyard ROD

Northeast of 9712 This consists of a paved yard used for container accumulation. garage, UEFPC Y-12
Will be addressed

in UEFPC

Soils and

Scrapyard ROD

\section{Will}

address in UEFPC

Soil and Scrapyard ROD
The site has been used for the storage of oils and solvents and is undiked. Tank 0084-U (YS-201) was also located within the yard and stored similar materials until it was removed in 1988. The polyethylene tanks and drums are on sheets of polyethylene and the area is diked. A metal awning covers the container accumulation area. Surface drainage from the site flows into either a sump to the northwest, or a catch basin to the south. Tank 0084-U (YS-201) is located adjacent to this site. This site has been used since 1955 for a less-than-90-day accumulation of used oil, gasoline, waste diesel fuel, varsol, carburetor cleaner and degreasers (methylene chloride), ethylene glycol, used batteries, tires, and scrap metal. Initially the site was partly paved and
Uranium oxide

disposal site,

part of YP-500
Historical

Waste oil

Includes 90-day accumulation area (AA-03); historical waste storage
Historical

Historical 
SWMU HSWA

permit

Unit ID

Unit location

CERCLA

appendix

number Unit title

History

FFA status

SWMU note

partly covered with gravel. At that time, drums and batteries were stored on the gravel, and the gravel had been stained. Currently the site is completely paved. There are no documented releases from this site; however, the observance of stained gravel and period of operation indicate releases are likely.

1070 Building 9720-12 Building 9720-12,

Classified West End of

Container Building.

Storage Unit

(PER-51)

1072 Building 9720-13 South side of Tank 9720-13

1073 Building 9720-13 Northwest of West Yard Waste 9720-13, Storage Area Subbasin

This site is an active $416 \mathrm{ft}^{2}$ paved container accumulation area. The pavement in the area has numerous cracks. This site has been used for the accumulation of uranium-contaminated trash and used oils since 1981. An SI was scheduled to be completed in FY 1992, after which construction of a Weapons Return Facility on this site was scheduled to proceed. It is not indicated whether this occurred. There are no known releases from this site;

however, migration of contaminants may have occurred before the yard was paved.

1077 Building 9720-2 TBD

Drum Storage

Area

1084 Building 9720-3 North of 9720-3, North Yard UEFPC

Waste Storage Subbasin G at

Area

Y-12

This site consists of a $320 \mathrm{ft}^{2}$ uncovered paved pad used for container accumulation. Four tanks ( $\sim 2530 \mathrm{ft}$ tall) are within the confines of the storage yard. This site was used only in 1986 for the storage of uranium-contaminated trash. There are no documented releases at this site; however, the uses and contents of the tanks are unclear.

\section{RCRA permit (TNHW 084); also PCB}

storage TS-22

\section{CWA}

Permit-by-rule

Will be

addressed

in UEFPC

Soil and

Scrapyard

ROD

\section{Uranium}

contaminated

trash, waste oil

Historical

Product storage

Historical

area

Will be
addressed
in UEFPC
Soils and
Scrapyard
ROD

Uranium contaminated trash

Historical 
SWMU HSWA

permit

appendix

\begin{tabular}{|c|c|c|c|c|c|c|}
\hline $\begin{array}{l}\text { Unit ID } \\
\text { number }\end{array}$ & Unit title & $\begin{array}{l}\text { Unit location } \\
\text { description }\end{array}$ & History & $\begin{array}{c}\text { CERCLA } \\
\text { FFA status }\end{array}$ & SWMU note & $\begin{array}{c}\text { appendix } \\
\text { classification }^{a}\end{array}$ \\
\hline 1089 & $\begin{array}{l}\text { Building 9720-6 } \\
\text { North Polytank } \\
\text { Station }\end{array}$ & $\begin{array}{l}\text { South of } 9720-6 \\
\text { UEFPC } \\
\text { Subbasin A at } \\
\text { Y-12 }\end{array}$ & $\begin{array}{l}\text { The unit consists of two asphalt pads with two } 600 \text {-gal polytanks. } \\
\text { This site is a less-than-90-days accumulation area. The North } \\
\text { Polytank Station was operated as a hazardous waste accumulation } \\
\text { area from } 1983 \text { until tank removal. Wastes stored on-site were } \\
\text { laboratory and miscellaneous wastewater. No releases were } \\
\text { documented. The date of tank removal and the characteristics of } \\
\text { the wastes stored at this site are not clear. }\end{array}$ & $\begin{array}{l}\text { Will be } \\
\text { addressed } \\
\text { in UEFPC } \\
\text { Soil and } \\
\text { Scrapyard } \\
\text { ROD }\end{array}$ & $\begin{array}{l}\text { Former RCRA } \\
90 \text {-day } \\
\text { accumulation } \\
\text { area }\end{array}$ & Historical \\
\hline 1095 & $\begin{array}{l}\text { Building 9720-9 } \\
\text { Storage Facility }\end{array}$ & $\begin{array}{l}\text { North side of 3rd } \\
\text { Street, South of } \\
9201-4\end{array}$ & & & $\begin{array}{l}\text { RCRA Permit } \\
\text { (TNHW 083); } \\
\text { also PCB } \\
\text { storage (TS-01). }\end{array}$ & A-2 \\
\hline 1104 & $\begin{array}{l}\text { Building } 9744 \\
\text { North Dock } \\
\text { Waste Storage } \\
\text { Area }\end{array}$ & $\begin{array}{l}\text { Northeast of } \\
\text { Bldg. 9744; } \\
\text { UEFPC } \\
\text { Subbasin F at } \\
\text { Y-12 }\end{array}$ & $\begin{array}{l}\text { This area is a loading dock used to store uranium-contaminated } \\
\text { filters. This location is partially paved and is surrounded by } \\
\text { gravel. Releases to soil are unlikely considering the site stored } \\
\text { only packaged solid wastes; no liquid wastes have been stored at } \\
\text { this site. There are no documented releases, and the lack of } \\
\text { liquids and packaging of waste make the potential for releases } \\
\text { minimal. }\end{array}$ & $\begin{array}{l}\text { Will be } \\
\text { addressed } \\
\text { by UEFPC } \\
\text { Soil and } \\
\text { Scrapyard } \\
\text { ROD }\end{array}$ & $\begin{array}{l}\text { Uranium } \\
\text { contaminated } \\
\text { filters }\end{array}$ & Historical \\
\hline 1107 & $\begin{array}{l}\text { Building } 9766 \\
\text { Beryllium } \\
\text { Contaminated } \\
\text { Ducts }\end{array}$ & $\begin{array}{l}\text { Attic of } \\
\text { Bldg. 9766, } \\
\text { between First } \\
\text { Street and Copper } \\
\text { Drive, west of } \\
\text { Calcium Drive at } \\
\text { Y-12 }\end{array}$ & $\begin{array}{l}\text { Building } 9766 \text { was built in the } 1950 \text { s as a machine shop for } \\
\text { milling beryllium and possibly thorium. An overhead duct system } \\
\text { exhausted and filtered airborne particulate. Machine shop } \\
\text { operations ceased in } 1965 \text {. }\end{array}$ & $\begin{array}{l}\mathrm{RI} / \mathrm{FS} \text { in } \\
\text { progress }\end{array}$ & $\begin{array}{l}\text { Building active; } \\
\text { (*Beryllium } \\
\text { dust has similar } \\
\text { concern as } \\
\text { asbestos) }\end{array}$ & Historical \\
\hline 1114 & $\begin{array}{l}\text { Building } 9808 \\
\text { Tank }\end{array}$ & $\begin{array}{l}\text { Building } 9808 \text {, } \\
\text { southeast corner }\end{array}$ & & & $\begin{array}{l}\text { CWA } \\
\text { Permit-by-rule }\end{array}$ & A-2 \\
\hline
\end{tabular}




\begin{tabular}{|c|c|c|c|c|c|c|}
\hline $\begin{array}{l}\text { Unit ID } \\
\text { number }\end{array}$ & Unit title & $\begin{array}{c}\text { Unit location } \\
\text { description }\end{array}$ & History & $\begin{array}{c}\text { CERCLA } \\
\text { FFA status }\end{array}$ & SWMU note & $\begin{array}{l}\text { SWMU HSWA } \\
\text { permit } \\
\text { appendix } \\
\text { classification }^{a}\end{array}$ \\
\hline 1116 & $\begin{array}{l}\text { Building 9811-1 } \\
\text { Container } \\
\text { Storage Unit } \\
(\text { OD-8)(PER-24) }\end{array}$ & $\begin{array}{l}\text { 2nd Street and K } \\
\text { Road, east of } \\
9720-16\end{array}$ & & & $\begin{array}{l}\text { RCRA permit } \\
\text { (TNHW 083); } \\
\text { also PCB } \\
\text { storage (TS-04). } \\
\text { RCRA clean } \\
\text { closed; awaiting } \\
\text { TDEC } \\
\text { certification. }\end{array}$ & A-2 \\
\hline 1117 & $\begin{array}{l}\text { Building 9811-1 } \\
\text { RCRA Tank } \\
\text { Storage Facility } \\
\text { (OD-7) }\end{array}$ & $\begin{array}{l}\text { 2nd Street and K } \\
\text { Road, east of } \\
9720-16\end{array}$ & & & $\begin{array}{l}\text { RCRA Permit } \\
\text { (TNHW 032); } \\
\text { also PCB } \\
\text { Storage } \\
\text { (TS-10). RCRA } \\
\text { clean closed; } \\
\text { awaiting TDEC } \\
\text { certification. }\end{array}$ & A-2 \\
\hline 1141 & $\begin{array}{l}\text { Burnhouse } \\
\text { Bldg. 9811\} }\end{array}$ & $\begin{array}{l}\text { South of Second } \\
\text { Street, east of } \\
\text { Bldg. } 9401-2\end{array}$ & & & $\begin{array}{l}\text { Building } \\
\text { removed 1993; } \\
\text { used for } \\
\text { incineration of } \\
\text { paper, photo, } \\
\text { tapes }\end{array}$ & A-2 \\
\hline 1142 & $\begin{array}{l}\text { Central Pollution } \\
\text { Control Facility }\end{array}$ & $\begin{array}{l}9623 \text {, Entire } \\
\text { Building and } \\
\text { related southside } \\
\text { dock area }\end{array}$ & & & $\begin{array}{l}\text { CWA } \\
\text { wastewater } \\
\text { treatment }\end{array}$ & A-2 \\
\hline
\end{tabular}




\begin{tabular}{|c|c|c|c|c|c|c|}
\hline $\begin{array}{l}\text { Unit ID } \\
\text { number }\end{array}$ & Unit title & $\begin{array}{l}\text { Unit location } \\
\text { description }\end{array}$ & History & $\begin{array}{c}\text { CERCLA } \\
\text { FFA status }\end{array}$ & SWMU note & $\begin{array}{l}\text { SWMU HSWA } \\
\text { permit } \\
\text { appendix } \\
\text { classification }^{a}\end{array}$ \\
\hline 1149 & $\begin{array}{l}\text { Building 9720-25 } \\
\text { Classified Waste } \\
\text { Storage Facility }\end{array}$ & $\begin{array}{l}\text { Building 9720-25, } \\
\text { (permitted area - } \\
\text { northwest corner) }\end{array}$ & & & $\begin{array}{l}\text { RCRA Permit } \\
\text { (TNHW 083); } \\
\text { also PCB } \\
\text { storage (TS-41). }\end{array}$ & A-2 \\
\hline 1150 & Coal Pile Trench & $\begin{array}{l}\text { Southwestern part } \\
\text { of the Y-12 Plant, } \\
\text { underneath the } \\
\text { northeast section } \\
\text { of the coal pile; } \\
\text { UEFPC Subbasin }\end{array}$ & $\begin{array}{l}\text { The coal pile is located in the southwestern part of the Y-12 } \\
\text { Plant. The trench is located underneath the northeast section of } \\
\text { the coal pile. The trench may be as deep as } 1820 \mathrm{ft} \text { in places, and } \\
\text { it is speculated that the trench may extend to bedrock. The trench } \\
\text { received } 2000 \text { tons of waste containing depleted uranium and } \\
\text { depleted uranium alloys from } 1965 \text { to } 1966 \text {. In } 1966 \text { the waste } \\
\text { was compacted with a wrecking ball, and a } 4 \text {-ft-thick clay cap } \\
\text { was placed over the trench. Sparks from the wrecking ball ignited } \\
\text { a uranium fire that lasted } 3 \text { days starting on September } 2,1966 \text {. } \\
\text { Excavations into the trench in } 1983 \text { also ignited a uranium fire. } \\
\text { The excavations revealed that at least half of the waste was } \\
\text { saturated with water. There are no documented releases from this } \\
\text { site. }\end{array}$ & $\begin{array}{l}\text { Will be } \\
\text { addressed } \\
\text { in UEFPC } \\
\text { Soils and } \\
\text { Scrapyard } \\
\text { ROD }\end{array}$ & $\begin{array}{l}\text { Disposal trench } \\
\text { under coal pile; } \\
\text { primarily } \\
\text { rad-cont. solid } \\
\text { waste }\end{array}$ & A-1(a) \\
\hline 1153 & $\begin{array}{l}\text { Cooling Tower } \\
\text { Basin 9409-3 }\end{array}$ & $\begin{array}{l}\text { UEFPC } \\
\text { Subbasin A at } \\
\text { Y-12 }\end{array}$ & $\begin{array}{l}\text { The Cooling Tower Basin (Bldg. 9409-3) was originally part of } \\
\text { the Z-oil system. The cooling coils were drained and flushed, and } \\
\text { the lumber from the tower was placed in the basin and covered } \\
\text { with dirt to provide a controlled storage until a suitable means of } \\
\text { decontamination becomes available. Mercury-contaminated soil } \\
\text { from the Third Street soil pile (YS-116) was stored temporarily at } \\
\text { the site. No releases have been documented. }\end{array}$ & $\begin{array}{l}\text { Will be } \\
\text { included in } \\
\text { UEFPC } \\
\text { Soils and } \\
\text { Sprayer } \\
\text { ROD }\end{array}$ & $\begin{array}{l}\text { Contains } \\
\text { demolition } \\
\text { debris from } \\
\text { towers }\end{array}$ & A-1(a) \\
\hline 1154 & $\begin{array}{l}\text { Cyanide } \\
\text { Treatment Unit } \\
(\text { PER-01) }\end{array}$ & $\begin{array}{l}\text { Building } 9201-5 \mathrm{~N} \\
\text {, First Floor }\end{array}$ & & & $\begin{array}{l}\text { RCRA permit } \\
\text { (TNHW-084) }\end{array}$ & A-2 \\
\hline
\end{tabular}


SWMU HSWA

permit

\begin{tabular}{ccc}
$\begin{array}{c}\text { Unit ID } \\
\text { number }\end{array}$ Unit title & $\begin{array}{c}\text { Unit location } \\
\text { description }\end{array}$ \\
\hline
\end{tabular}

1158 Development

South of

Incinerator

Bldg. 9731,

UEFPC

Subbasin $\mathrm{C}$ at

Y-12

1181 Fire Training

Facility Soils

TBD

This site is located north of the former Bldg. 9754 and was the location of three metal USTs. This site was part of a fueling and service station (Bldg. 9754) built in 1945. The original

construction consisted of two 10,000-gal tanks for the storage of leaded gasoline and diesel fuel. The tanks were installed on a

concrete slab, below grade, inside an earthen dike with space for an additional tank. The third tank, a 20,000-gal unit, was installed in 1974 for the storage of unleaded gasoline. These three tanks gravity fed three 1000-gal holding tanks (YS-506, YS-507, and YS-508) and two emergency dispensers near Bldg. 9754 through fiberglass piping. In 1977, a new gasoline filling station was constructed west of Bldg. 9754 that included new fuel storage tanks. Consequently, use of the garage USTs for storing gasoline and diesel fuel was discontinued. At the same time, the three 1000-gal holding tanks were emptied and abandoned, and the appendix

CERCLA

FFA status

SWMU note

classification $^{a}$

992

Will be

Removed; burn

A-2

included in misc. wastes

UEFPC

Soils and

Scrapyard

ROD

Historical

burning of

waste oils on

gravel;

suspected

source of GW

contamination.

$\mathrm{RI} / \mathrm{FS}$ in

RCRA clean

progress closure 2/95;

also PCB

storage (TS-25)
A-2 
emergency dispensers were taken out of service. Beginning in

1980, the three tanks in YS-019 were used to store waste oils. A tank inspection before closure observed no signs of leakage and indicated no staining or cracking of the concrete pad beneath the tanks. The tanks were removed in October 1989. The site was clean closed in 1994. As part of the clean closure it was remediated for cadmium in soils. Approximately 40 drums of soi were removed from the site. All other clean closure criteria had been met. The west tank (20,000 gal, previously used for unleaded gasoline) and the middle tank (10,000 gal, previously used for leaded gasoline) have stored RCRA waste oils containing spent solvents (perchloroethylene and Freon-113) and contaminated with PCBs as well as uranium. These two tanks were closed per RCRA. The third tank (10,000 gal, previously used for diesel fuel), located to the east, was used for storage of non-RCRA waste oil and was closed per TSCA. It is unclear whether the piping from the garage USTs to the holding tanks was removed or dismantled before the use of the garage USTs to store used oils. There are no documented releases from this site and it is not considered a likely source of contamination to UEFPC.

1185 Interim Drum Yard $\{$ North/South
West of

Bldg. 9720-32, in

UEFPC

Subbasin I
The yard is constructed of gravel on native soil and has no liner. Secondary containment was provided by plastic sheeting diked 6 in. at the outer edges. Two such pads were covered with canvas tent structures. Drummed wastes were stored on pallets. The area was first used in 1984 for the storage of drums of chlorinated and nonchlorinated organics, halogenated solvents, acetonitrile, uranyl nitrate solution, asbestos, mixed wastes,

PCB-contaminated materials, chromium-containing sludge, mercury-contaminated wastes, and plating solutions. This yard received wastes from the Waste Machine Coolant Biodegradation Facility and Acetonitrile (ACN) Drum Yard. The southern edge
Will be

included in

UEFPC

Soils and

Scrapyard ROD
RCRA clean closure south 1988; north closure deferred to CERCLA; also PCB storage (TS-05) 
Unit title History

underwent RCRA clean closure (due to PIDAS corridor needs)
and the closure certification package has been prepared for the

remainder of the site. Analysis from the southern edge of the site indicated only cadmium exceeded the maximum allowable limits established in the approved closure plan. These soils were

excavated in 1987. There are no documented releases from this

site, and it is not considered a source of contamination to UEFPC.

\section{K-1654-A Vent TBD Exhaust Area}

1190 K-1654-A Waste TBD

Accumulation

Tank $\{$ septic

tank\}

1197 Laundry Sump
South side of Bldg. 9728; UEFPC

Subbasin B
The inactive laundry sump is located primarily below ground. The sump is a concrete wastewater sump with stainless steel covers attached to wooden 2 by 4's. The sump was emptied in 1985. The interior of the sump is $18.5 \mathrm{ft}$ long, $9 \mathrm{ft}$ wide, and $12 \mathrm{ft}$ deep. The total volume of the sump is 1500 gal, with capacity at normal overflow level $\sim 8600$ gal. The sump was designed to allow solids settling and scum removal before discharge to the storm water system and ultimately Outfall 22 into UEFPC. The Bldg. 9728 Laundry Sump was constructed during late 1943 to receive wastewater from the laundering of coveralls, towels,

respirator filters, mop heads, and rugs. The laundering operation and use of the sump were discontinued in 1985. At that time, the
Formerly C077

SWMU;

transfer to Y-12

1/95; Possible

$\mathrm{Pb}$

contamination

in surrounding

soil

Suspected $\mathrm{Pb}$

contamination

in drain field

Will be

addressed

Inactive

in UEFPC

wastewater

sump 
SWMU HSWA

permit

Unit ID

Unit location

History

CERCLA

appendix

number Unit title description

contents of the pit (wastewater with some solids) were removed and placed in 55-gal drums. The drums were bailed of this liquid phase, which was treated by the Y-12 Plant Waste Treatment

Operations. The drums and remaining solids were disposed of in the Bear Creek Burial Grounds.

\begin{tabular}{|c|c|c|}
\hline 1198 & $\begin{array}{l}\text { Line Yard } \\
\text { Contaminated } \\
\text { Soils }\end{array}$ & $\begin{array}{l}\text { The Line Yard is } \\
\text { located on the east } \\
\text { side of the Y-12 } \\
\text { Plant between } \\
\text { Bldgs. } 9720-8 \text { and } \\
9201-3 \text { and } \\
\text { Second and Third } \\
\text { Streets. }\end{array}$ \\
\hline 1199 & $\begin{array}{l}\text { Liquid Organic } \\
\text { Waste Storage } \\
\text { Facility (OD-10) }\end{array}$ & $\begin{array}{l}\text { Building 9720-45/ } \\
\text { north side of Bear } \\
\text { Creek Road }\end{array}$ \\
\hline
\end{tabular}

1200 Machine Coolant North side of Storage Second Street, Tanks/Sumps Between 9811-1 and $9404-16$

1201 Mercury Contaminated Several sites in UEFPC

Mercury-contaminated areas include facilities where mercury E, G, and $\mathrm{H}$ )

contaminated as a result of releases from mercury-handling facilities. Major facilities that handled mercury are listed below (building-subbasin-mercury use). 9733-1 (D) No information,

\begin{tabular}{|c|c|}
\hline \multirow[t]{3}{*}{$\begin{array}{l}\text { Will be } \\
\text { address } \\
\text { under the } \\
\text { UEFPC } \\
\text { Soils and } \\
\text { Scrapyard } \\
\text { ROD }\end{array}$} & $\begin{array}{l}\text { PCB } \\
\text { spills/stains } \\
\text { removed; PCB } \\
\text { equipment } \\
\text { storage }\end{array}$ \\
\hline & $\begin{array}{l}\text { RCRA Permit } \\
\text { (TNHW 032); } \\
\text { also PCB } \\
\text { storage (TS-17) } \\
\text { RCRA clean } \\
\text { closure TDEC } \\
\text { certified } \\
\text { 11/6/01. }\end{array}$ \\
\hline & $\begin{array}{l}\text { CWA } \\
\text { Permit-by-rule; } \\
\text { part of YT-038 }\end{array}$ \\
\hline $\begin{array}{l}\text { Will be } \\
\text { addressed } \\
\text { in UEFPC } \\
\text { Soils and } \\
\text { Scrapyard }\end{array}$ & $\begin{array}{l}\text { Includes } \\
\text { multiple areas } \\
\text { throughout } \\
\text { Y-12; } \\
\text { contamination }\end{array}$ \\
\hline
\end{tabular}




FFA status

9733-2 (D) Less than $100 \mathrm{lbs} \mathrm{Hg}$ used, 9202 (A) 50,000 lbs Hg lost, 9201-2 (A) 135,157 lbs Hg lost, 9204-4 (H/I) No information, 9201-5 (E/H) Approximately 200,000 lbs Hg lost, 9201-4 (G) 25-30 K lbs Hg still in process equipment, 81-10 (E) 3,000 lbs Hg in soil near building. Extensive use of mercury at the Y-12 Plant began in the mid-1950s. In order to separate 7Li from 6Li for use in thermonuclear weapons, a column exchange (COLEX) process, was developed to exploit the fact that 6 $\mathrm{Li}$ is more soluble in mercury under certain conditions. A total of $2,000,000 \mathrm{lb}$ of mercury was lost, $428,000 \mathrm{lb}$ to the ground and $1,300,000 \mathrm{lb}$ not accounted for. An estimated 300,000 lb is still in buildings and appurtenances.

This unlined, man-made pond was built in 1963 and was used to settle contaminated sediments out of UEFPC. New Hope Pond (NHP) served as a settling basin to remove suspended sediments from UEFPC before discharge to LEFPC. The pond had a volume of $\sim 46,500 \mathrm{yd}^{3}$, of which $24,000 \mathrm{yd}^{3}$ were filled with sediment.

ROD

SWMU HSWA

permit

appendix classification $^{a}$

leaks and/or

spills $\begin{array}{lll} & \text { Soils and permit 8/96 }\end{array}$ and was disposed of in the Chestnut Ridge Sediment Disposal Basin (YD-025). In 1984, a bypass ditch was constructed around the site to allow UEFPC to be diverted. Flow from UEFPC entered NHP by way of 12 discharge inlets located in a diversion-distribution channel. Later, this site was capped and covered with vegetation in a RCRA "dirty" closure completed in 1990. The water from NHP was released through an

NPDES-permitted outfall, and the sediment was left in place and was capped and covered. Removal of the sediment was not considered feasible because of the levels of PCBs, mercury, and uranium. An oil skimmer, used to collect oil and floating debris from the inflow, was located at the inlet of NHP. There are documented releases from this site, and groundwater and soil data 


\begin{tabular}{|c|c|c|c|c|c|c|}
\hline $\begin{array}{l}\text { Unit ID } \\
\text { number }\end{array}$ & Unit title & $\begin{array}{c}\text { Unit location } \\
\text { description }\end{array}$ & History & $\begin{array}{l}\text { CERCLA } \\
\text { FFA status }\end{array}$ & SWMU note & $\begin{array}{l}\text { SWMU HSWA } \\
\text { permit } \\
\text { appendix } \\
\text { classification }^{a}\end{array}$ \\
\hline & & & $\begin{array}{l}\text { confirm the presence of contamination. The vertical extent of } \\
\text { contamination is uncertain. }\end{array}$ & & & \\
\hline 1208 & $\begin{array}{l}\text { Old Fuel Station } \\
\text { Site }\end{array}$ & TBD & & & $\begin{array}{l}\text { Suspected } \\
\text { petroleum } \\
\text { contaminated } \\
\text { soils }\end{array}$ & A-2 \\
\hline 1209 & $\begin{array}{l}\text { Old Steam Plant } \\
\text { Storage Area } \\
\text { \{Bldg. 9401-1\} }\end{array}$ & $\begin{array}{l}\text { West end of } \\
9401-1 \text { at Y-12; } \\
\text { UEFPC } \\
\text { Subbasin A }\end{array}$ & $\begin{array}{l}\text { The area was previously used to store small volumes of } \\
\text { chemicals. The site was clean closed under RCRA requirements } \\
\text { around 1986. In 1986, four concrete samples were collected from } \\
\text { the floor before closure. The concrete was analyzed for EP Tox } \\
\text { for metals (barium, cadmium, chromium, lead, and mercury) and } \\
\text { TCLP for organics (carbon tetrachloride, methanol, methylene } \\
\text { chloride, methyl ethyl ketone, methyl isobutyl ketone, } \\
\text { tetrachloroethylene, toluene, trichloroethane, trichloroethylene, } \\
\text { and trichlorofluoromethane) All results were essentially below } \\
\text { detection levels. }\end{array}$ & $\begin{array}{l}\text { Will be } \\
\text { addressed } \\
\text { in the } \\
\text { UEFPC } \\
\text { Soils and } \\
\text { Scrapyard } \\
\text { ROD }\end{array}$ & $\begin{array}{l}\text { RCRA clean } \\
\text { closure } 1986\end{array}$ & A-2 \\
\hline 1210 & $\begin{array}{l}\text { Plating } \\
\text { Rinsewater } \\
\text { Treatment } \\
\text { Facility }\end{array}$ & $\begin{array}{l}\text { Building 9623, } \\
\text { north side of } \\
\text { Second Street }\end{array}$ & & & $\begin{array}{l}\text { CWA } \\
\text { wastewater } \\
\text { treatment; } \\
\text { includes } \\
\text { permit-by-rule } \\
\text { tanks }\end{array}$ & A-2 \\
\hline 1211 & $\begin{array}{l}\text { Polytank Station } \\
\{\text { Bldg. } 9206\}\end{array}$ & $\begin{array}{l}\text { Southeast side of } \\
\text { Bldg. 9206; } \\
\text { UEFPC } \\
\text { Subbasin F }\end{array}$ & $\begin{array}{l}\text { This paved area is the location of two } 600 \text {-gal polytanks that have } \\
\text { been used to contain rinse water/mop water and acetic acid since } \\
1983 \text {. The tank is a less-than- } 90 \text {-day accumulation area and has } \\
\text { been temporarily diked with sandbags. The polytanks have } \\
\text { received rinse water/mop water and acetic acid since } 1983 \text {. There } \\
\text { are no documented releases; however, the presence of liquids and } \\
\text { lack of soil and groundwater data make the extent of possible } \\
\text { releases uncertain. }\end{array}$ & $\begin{array}{l}\text { Will be } \\
\text { addressed } \\
\text { in UEFPC } \\
\text { Soil and } \\
\text { Scrapyard } \\
\text { ROD }\end{array}$ & $\begin{array}{l}\text { Former } 90 \text {-day } \\
\text { accumulation } \\
\text { area; SID 30/31 } \\
\text { wastewaters }\end{array}$ & Historical \\
\hline
\end{tabular}




\begin{tabular}{|c|c|c|}
\hline $\begin{array}{l}\text { Unit ID } \\
\text { number }\end{array}$ & Unit title & $\begin{array}{c}\text { Unit location } \\
\text { description }\end{array}$ \\
\hline 1214 & $\begin{array}{l}\text { Prenco } \\
\text { Incinerator }\end{array}$ & $\begin{array}{l}\text { East of the } 9811-1 \\
\text { storage facility } \\
\text { and machine } \\
\text { coolant storage } \\
\text { tanks; UEFPC } \\
\text { Subbasin H }\end{array}$ \\
\hline 1215 & $\begin{array}{l}\text { Building 9720-31 } \\
\text { Mixed Waste } \\
\text { Storage and } \\
\text { Staging Area }\end{array}$ & $\begin{array}{l}\text { 9720-31, South } \\
\text { side of West Third } \\
\text { Street }\end{array}$ \\
\hline 1216 & $\begin{array}{l}\text { RCRA and PCB } \\
\text { Container } \\
\text { Storage Area; } \\
\text { Bldg. 9720-58 } \\
\text { (PER-4 }\end{array}$ & Building 9720-58 \\
\hline
\end{tabular}

RCRA Permit
(TNHW 083);
a.k.a. "RCRA motel"

RCRA permit (TNHW 083); also PCB storage (TS-03 and TS-11). RCRA clean closed; awaiting TDEC

certification.
SWMU HSWA

permit

appendix classification $^{a}$ resulting in cyanide/hydrogen cyanide formation. ACN was were stored on-site for no more than 5 days before are no documented releases from this site; however, airborne missions resulted from the incineration process. The Prenco with a drain, a drum unloading and staging area, and the incinerator. The remainder of the site area was gravel. Total operated at $30 \mathrm{gal} / \mathrm{hour}$. The site has been dismantled and demolished, and the site was clean closed per RCRA requirements in 1987.

\section{CERCLA} flushed with water, and the water was burned in the incinerator. incineration. The incinerator operated $\sim 2$ weeks each year. There

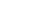

$n^{a}$

a

A-2 


\begin{tabular}{|c|c|c|c|c|c|c|}
\hline $\begin{array}{l}\text { Unit ID } \\
\text { number }\end{array}$ & Unit title & $\begin{array}{c}\text { Unit location } \\
\text { description }\end{array}$ & History & $\begin{array}{c}\text { CERCLA } \\
\text { FFA status } \\
\end{array}$ & SWMU note & $\begin{array}{c}\text { SWMU HSWA } \\
\text { permit } \\
\text { appendix } \\
\text { classification }^{a} \\
\end{array}$ \\
\hline 1217 & $\begin{array}{l}\text { Ravine Disposal } \\
\text { Site }\end{array}$ & $\begin{array}{l}\text { North of } 9712 \text { in a } \\
\text { ravine that } \\
\text { parallels Bear } \\
\text { Creek Road; } \\
\text { UEFPC } \\
\text { Subbasin K }\end{array}$ & $\begin{array}{l}\text { The Ravine Disposal Site was used for the disposal of primary } \\
\text { construction spoils and possibly a small amount of scrap metal, } \\
\text { including some uranium, from } 1943 \text { to } 1952 \text {. There are no } \\
\text { documented releases from this site; however, sporadic detections } \\
\text { of VOCs and metals in groundwater indicate possible releases. A } \\
\text { water main runs beneath the site, and in } 1957 \text { storm sewer lines } \\
\text { were installed in the area. }\end{array}$ & $\begin{array}{l}\text { Will be } \\
\text { addressed } \\
\text { in UEFPC } \\
\text { Soils and } \\
\text { Scrapyard } \\
\text { ROD }\end{array}$ & $\begin{array}{l}\text { Construction } \\
\text { debris/spoils, } \\
\text { possibly } \\
\text { uranium. }\end{array}$ & A-1(a) \\
\hline 1218 & $\begin{array}{l}\text { Roofing Waste } \\
\text { Pile }\{\text { former }\}\end{array}$ & $\begin{array}{l}\text { East of 9720-13; } \\
\text { UEFPC } \\
\text { Subbasin I }\end{array}$ & $\begin{array}{l}\text { This site is a pile of mercury-contaminated roofing waste } \\
\text { materials, underlain by a synthetic membrane to prevent release } \\
\text { to soil or groundwater. The materials could also have been } \\
\text { contaminated with airborne radionuclides from nearby production } \\
\text { operations during storage. The pile was underlain by a } 20 \text {-mil } \\
\text { synthetic membrane, which was overlain with plywood to } \\
\text { minimize tearing. A berm of soil covered with the synthetic } \\
\text { membrane was maintained around the perimeter of the site to } \\
\text { contain soil in the piles. The waste piles were removed from the } \\
\text { site in mid-1987 and placed in a temporary storage area on } \\
\text { Chestnut Ridge. }\end{array}$ & & $\begin{array}{l}\mathrm{Hg}, \mathrm{rad} \\
\text { contaminated } \\
\text { debris; moved } \\
\text { to YS-126 }\end{array}$ & A-1(a) \\
\hline 1219 & $\begin{array}{l}\text { Rust } \\
\text { Construction } \\
\text { Garage Area }\end{array}$ & $\begin{array}{l}\text { Northeast of } \\
\text { 9831; UEFPC } \\
\text { Subbasin J }\end{array}$ & $\begin{array}{l}\text { The Rust Maintenance Garage area has been used for the storage } \\
\text { of construction equipment from } 1972 \text { to the present. Releases } \\
\text { from USTs and their piping are known to have occurred, and soil } \\
\text { samples have shown the presence of diesel fuel, volatile organics, } \\
\text { and heavy metals. In 1987, two areas were determined to have oil } \\
\text { leak problems: an equipment wash pad north of the Building was } \\
\text { identified as a source of oil and other contaminants, and a drum } \\
\text { storage area was reported to be improperly storing leaking oil } \\
\text { drums. These areas were paved with asphalt in } 1987 \text { to prevent } \\
\text { contamination through surface water runoff or infiltration of } \\
\text { water through the soil into groundwater. There are documented } \\
\text { releases from this site and it is a possible source of contamination } \\
\text { to UEFPC. The site consists of three excavated areas where the }\end{array}$ & & $\begin{array}{l}\text { Historical waste } \\
\text { storage, RCRA } \\
\text { Subtitle I UST, } \\
\text { pulled by } 1989, \\
\text { groundwater } \\
\text { cont. deferred to } \\
\text { CERCLA }\end{array}$ & A-1(a) \\
\hline
\end{tabular}




政

SWMU HSWA

permit

appendix

CERCLA

History

\section{Unit ID number} Unit title

Unit location description three 9754-1 tanks, the gasoline transfer line, and the abandoned

1,000-gal tank (2068-U) were once located. The garage area

includes a former used oil drum storage lot, an equipment wash pad, an abandoned gasoline UST (2068-U), and a storage area for drums of new oil. The 9754-1 tanks were a 12,000-gal diesel tank (1219-U), a 12,000-gal gasoline tank(1222- U), and an 8,000-gal gasoline tank (2082-U); these tanks were located in one tank bay south of Bldg. 9741-1. Tank 2068-U is being evaluated as site YS-505.

\section{S-2 Site} Groundwater

Plume

\section{Salvage Yard Oil South of} Storage Tanks Bldg. 9114, east of Bldg. 9420-1; UEFPC

Subbasin J
South of 9720-32, Disposal pit was used for disposal of corrosive and toxic liquids, south side of Third Street; UEFPC

Subbasin I possibly halogenated and nonhalogenated solvents. Subsurface investigations including installation of monitoring wells, soil borings, and a conductivity survey indicated the presence of a contaminant plume migrating northward from the site in the direction of groundwater flow.

This site includes two upright non-RCRA carbon steel storage tanks for PCB-contaminated oils. The site contains one 5000-gal tank to the north, which was operated from 1980 to 1986, and one 6000-gal tank to the south, which was operated from 1978 to 1986. Tanks are located within rip- rap earthen dikes. PCB-contaminated oils were stored in the tanks. The south tank contained waste oils such as auto crankcase oil, vacuum pump oil, hydraulic fluids, and machining oils. The south tank oils contained up to $2100 \mathrm{ppm}$ PCBs and $775 \mathrm{ppm}$ chlorinated solvents. The north tank was used for mineral oils from transformer oil changeout, containing up to $86 \mathrm{ppm}$ PCBs and $850 \mathrm{ppm}$ chlorinated solvents. Spills and leaks have reportedly been contained within the dikes. There have been releases from this site, which may have resulted in soil contamination. 9-13-99: The CERCLA Area "Salvage Yard Oil Storage Tanks Contaminated Soils" was rolled up into this CERCLA Area.
Includes soils. Will be addressed in UEFPC Soils and

Scrapyard ROD
PCB waste oil, drained, suspected nearby contamination 


\begin{tabular}{|c|c|c|c|c|c|c|}
\hline $\begin{array}{l}\text { Unit ID } \\
\text { number }\end{array}$ & Unit title & $\begin{array}{c}\text { Unit location } \\
\text { description }\end{array}$ & History & $\begin{array}{c}\text { CERCLA } \\
\text { FFA status }\end{array}$ & SWMU note & $\begin{array}{l}\text { SWMU HSWA } \\
\text { permit } \\
\text { appendix } \\
\text { classification }^{a}\end{array}$ \\
\hline 1231 & $\begin{array}{l}\text { Scarboro Road } \\
\text { Debris Burial }\end{array}$ & $\begin{array}{l}\text { Approx. } 0.25 \text { mile } \\
\text { northeast of the } \\
\text { Y-12 Plant; } \\
\text { UEFPC } \\
\text { Subbasin K }\end{array}$ & $\begin{array}{l}\text { This site was discovered while a geophysical survey was being } \\
\text { conducted in the area. The geophysical data indicated that the site } \\
\text { contains concrete and other solid debris from a few feet to a few } \\
\text { tens of feet below land surface. These items were apparently } \\
\text { buried during the } 1943 \text { to } 1980 \text { time frame; however, no record is } \\
\text { known. }\end{array}$ & $\begin{array}{l}\text { Will be } \\
\text { addressed } \\
\text { in UEFPC } \\
\text { Soils and } \\
\text { Scrapyard } \\
\text { ROD }\end{array}$ & $\begin{array}{l}\text { Suspected } \\
\text { construction } \\
\text { spoils }\end{array}$ & A-1(a) \\
\hline 1233 & $\begin{array}{l}\text { Steam Plant } \\
\text { Wastewater } \\
\text { Treatment } \\
\text { Facility }\end{array}$ & $\begin{array}{l}\text { South side of } \\
\text { Bldg. 9616-9 }\end{array}$ & & & $\begin{array}{l}\text { CWA } \\
\text { wastewater } \\
\text { treatment, } \\
\text { includes } \\
\text { permit-by-rule } \\
\text { tanks }\end{array}$ & A-2 \\
\hline 1236 & $\begin{array}{l}\text { Tank } \\
\{\text { Bldg. 9206\} }\end{array}$ & 9206, West Yard & & & $\begin{array}{l}\text { CWA } \\
\text { Permit-by-rule; } \\
\text { caustic } \\
\text { solutions }\end{array}$ & A-2 \\
\hline 1237 & $\begin{array}{l}\text { Tank }\{\text { Near } \\
9204-3\}\end{array}$ & $\begin{array}{l}\text { Adjacent to NW } \\
\text { corner of } \\
\text { Bldg. 9204-3 }\end{array}$ & & & $\begin{array}{l}\text { CWA } \\
\text { Permit-by-rule; } \\
\text { former 90-day } \\
\text { accumulation } \\
\text { tank }\end{array}$ & A-2 \\
\hline 1238 & $\begin{array}{l}\text { Tank 0074-U } \\
\text { \{Bldg. 9201-5W\} }\end{array}$ & $\begin{array}{l}\text { Southwest corner } \\
\text { of the basement of } \\
\text { Bldg. 9201-5W; } \\
\text { UEFPC } \\
\text { Subbasin H }\end{array}$ & $\begin{array}{l}\text { The tank was used from } 1969 \text { to } 1987 \text { to store mop water that } \\
\text { may have contained dilute coolant (contaminated with uranium } \\
\text { and Freon). The top of the tank was flush with the basement floor } \\
\text { ( } 969 \mathrm{ft} \text { above msl), and the bottom of the tank was } 8 \mathrm{ft} \text { below the } \\
\text { basement floor. Photographs of the area indicate that the site is } \\
\text { more of an open pit covered with a grate, rather than a tank in the } \\
\text { conventional sense. In May 1987, the tank was excavated for } \\
\text { inspection and observed to collect groundwater. Inspection } \\
\text { revealed areas where water seeped in through the concrete tank }\end{array}$ & $\begin{array}{l}\text { Will be } \\
\text { addressed } \\
\text { in UEFPC } \\
\text { Soils and } \\
\text { Scrapyard } \\
\text { ROD }\end{array}$ & $\begin{array}{l}\text { CWA } \\
\text { Permit-by-rule; } \\
\text { Filled and } \\
\text { capped; } \\
\text { wastewater } \\
\text { sump }\end{array}$ & A-2 \\
\hline
\end{tabular}




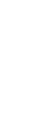

\begin{tabular}{l}
$\begin{array}{c}\text { Unit ID } \\
\text { number }\end{array} \quad$ Unit title $\quad \begin{array}{c}\text { Unit location } \\
\text { description }\end{array}$ \\
\hline
\end{tabular}

bottom. The tank originally emptied via an outlet line to UEFPC.

This outlet line was plugged and a sump pump installed at an unknown time. The tank was removed from service in December 1987, and the location was filled with gravel and capped with a 6-in. concrete slab.

\section{Tank 0688-U Building 9201-5E,}

\{Bldg. 9201-5\} Northeast Corner

of Basement, Col. K-3

\section{Tank}

Bldg. 9201-5N,

Station

216

\{Bldg. 9201-5N\}

1243 Tank 2063-U \{Salvage Yard

In the Salvage Yard, immediately west of the drum deheader/crusher facility; UEFPC Subbasin J
This tank, along with 2328-U, and 2329-U in the Salvage Yard, was used for the storage of residual oils and solvents from empty drums sent to the drum deheader. Drums to be deheaded contained residual materials, up to $1 \mathrm{in}$. in depth, that were poured into a drum placed inside tank 2063-U for secondary containment of spills. The contents of this tank traveled via a drainpipe to tanks $2328-\mathrm{U}$ and $2329-\mathrm{U}$, which also received liquids released from drum deheading or crushing, via floor drains. In 1979 the floor drains were plugged and the discharge to tanks $2328-\mathrm{U}$ and $2329-\mathrm{U}$ ceased. Until 1979, the tanks were covered only with grates, and received rainwater and runoff during rainstorms. The rubber baffle between tanks served to separate the oils from the water, which was then released into the plant storm water system via a 4-in. storm drain that traveled $75 \mathrm{ft}$ to the northwest. During heavy rains the tanks would overflow toward a storm water collection basin to the northwest. After 1979, the grates were replaced with metal plates, and
SWMU HSWA

permit

appendix

CERCLA

FFA status

SWMU note
Will be

addressed

in UEFPC

Soils and

Scrapyard

ROD
CWA

Permit-by-rule;

UST removed

1988; mopwater

storage

CWA

Permit-by-rule;

mopwater

storage; UST

Removed in

1989, drum

deheader waste 


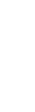

\begin{tabular}{l}
$\begin{array}{c}\text { Unit ID } \\
\text { number }\end{array}$ Unit title \\
\hline $\begin{array}{c}\text { Unit location } \\
\text { description }\end{array}$ \\
\hline
\end{tabular}

1244 Tank 2064-U \{Bldg. 9766\}

1253 Tank 2077-U
North side of the western portion of Bldg. 9766;

\section{UEFPC}

Subbasin D

1258 Tank 2089-U

1259 Tank 2090-U

Adjacent to the Bldg. 9995 at

Y-12 Plant

South of Bldg. 9733-1 in

UEFPC Sub-basi $\mathrm{C}$ at Y-12 Plant sandbags were also used to prevent runoff entering the tanks. The oils remaining in tanks $2328-\mathrm{U}$ and $2329-\mathrm{U}$ were periodically pumped out and treated or disposed in the Bear Creek Burial Grounds. The tanks were found to be leaking and taken out of service in March 1989, and removed in July 1989. The extent of contamination is uncertain.

west side of

The tank was in operation form 1946 to 1964 to store propane The underground tank was contained in a steel-capped, $6 \times 6 \mathrm{ft}$ concrete containment vault. beryllium-contaminated waste. Wastes were generated from machining of beryllium and thorium in Bldg. 9766. Wash water from exhaust air filter cleaning and floor drains was stored in tank 2064-U.

This tank stored gasoline for emergency generators from 1953 to 1964. The tank was then filled with water and abandoned in place until it was removed in 1986 .

FFA status

To be

addressed

in UEFPC

Soils and

Scrapyard

ROD

Will be

addressed

in UEFPC

Soils and

SWMU HSWA

permit

appendix classification $^{a}$

$\begin{array}{ll}\text { RI/FS in } & \text { Beryllium } \\ \text { progress } & \text { contaminated } \\ & \text { wastewater } \\ & \text { sump }\end{array}$

A-1(a)

Removed 1986;

petr. UST

Historical

Scrapyard

ROD

Propane storage Historical

tank; out of

service

Propane tank

Historical

Bldg. 9720-1,

south of Chlorine Dr. at Y-12
This tank was used 1946-64 for storage of propane. The tank was Will be in a steel-capped concrete containment vault with dimensions address in UEFPC

Soils and Scrapyard ROD 


\begin{tabular}{|c|c|c|c|c|c|c|}
\hline $\begin{array}{l}\text { Unit ID } \\
\text { number }\end{array}$ & Unit title & $\begin{array}{c}\text { Unit location } \\
\text { description }\end{array}$ & History & $\begin{array}{l}\text { CERCLA } \\
\text { FFA status }\end{array}$ & SWMU note & $\begin{array}{c}\text { SWMU HSWA } \\
\text { permit } \\
\text { appendix } \\
\text { classification }^{a}\end{array}$ \\
\hline 1260 & Tank 2091-U & $\begin{array}{l}\text { South of } \\
\text { Bldg. 9733-2 and } \\
\text { Chlorine Dr., in } \\
\text { UFPC Subbasin D }\end{array}$ & $\begin{array}{l}\text { This tank was used to store liquid propane from } 1946 \text { to } 1964 \text {. It } \\
\text { is located underground in a steel-capped concrete vault. }\end{array}$ & $\begin{array}{l}\text { Will be } \\
\text { addressed } \\
\text { in UEFPC } \\
\text { Soils and } \\
\text { Scrapyard } \\
\text { ROD }\end{array}$ & Propane tank & Historical \\
\hline 1261 & Tank 2092-U & $\begin{array}{l}\text { South of } 9733-4 \text {, } \\
\text { between } 2 \text { nd St. } \\
\text { and Chlorine Dr. } \\
\text { at Y-12 }\end{array}$ & $\begin{array}{l}\text { This unit was an underground tank used for the storage of } \\
\text { propane. The tank was located in a } 6 \times 6 \text { - } \mathrm{ft} \text { concrete vault. }\end{array}$ & $\begin{array}{l}\text { Will be } \\
\text { addressed } \\
\text { in UEFPC } \\
\text { Soils and } \\
\text { Scrapyard } \\
\text { ROD }\end{array}$ & Propane tank; & Historical \\
\hline 1262 & Tank 2100-U & $\begin{array}{l}\text { Southwest of } \\
\text { Bldg. 9201-4; } \\
\text { UEFPC } \\
\text { Subbasin E }\end{array}$ & $\begin{array}{l}\text { This 30,000-gal tank has received a methanol/water mixture, } \\
\text { used as coolant for the COLEX process, since 1951, and also was } \\
\text { used as a settling tank for mercury-contaminated water and } \\
\text { sediment from sumps in the basement of Bldg. } 9201-4 \text {. } \\
\text { Discharges through this tank to the storm drain system have been } \\
\text { as high as } 25,000 \text { gal per day. In } 1993 \text { the sediment in the tank } \\
\text { was removed and a small crack was sealed with epoxy-type paint. }\end{array}$ & $\begin{array}{l}\text { Remedial } \\
\text { action } \\
\text { complete } \\
\text { RAR } \\
\text { approved } \\
12 / 20 / 93\end{array}$ & $\begin{array}{l}\text { Wastewater } \\
\text { settling pit; } \\
\text { CERCLA ROD } \\
\text { 9/26/91 for Hg } \\
\text { contaminated } \\
\text { sludge removal }\end{array}$ & A-2 \\
\hline 1263 & Tank 2101-U & $\begin{array}{l}\text { Southeast of } \\
\text { Bldg. 9201-4; } \\
\text { UEFPC } \\
\text { Subbasin G }\end{array}$ & $\begin{array}{l}\text { This 32,000-gal tank is located southeast of Bldg. } 9201-4 \text { and } \\
\text { was used to store a methanol/water mixture. Mercury was spilled } \\
\text { in Bldg. } 9201-4 \text { and migrated into sumps in the fan room of the } \\
\text { building. Mercury and mercury-contaminated sediment was then } \\
\text { pumped from the basement, passed through the tank where any } \\
\text { sediment settled out, and entered the storm sewer system. Floor } \\
\text { drains in the Building also drained through the tank and into the } \\
\text { storm sewer system. This tank also received discarded acid wash } \\
\text { that resulted from washing mercury with a water/nitric acid } \\
\text { solution. In 1993, the oil, oily water, and sediment in the tank } \\
\text { were removed. It was noted that the bypass line was half full of } \\
\text { sludge and radioactive contamination. The tank is abandoned in }\end{array}$ & $\begin{array}{l}\text { Remedial } \\
\text { action } \\
\text { complete. } \\
\text { RAR } \\
\text { approved } \\
12 / 20 / 93\end{array}$ & $\begin{array}{l}\text { Wastewater } \\
\text { settling pit; } \\
\text { CERCLA ROD } \\
\text { 9/26/91 for Hg } \\
\text { contaminated } \\
\text { sludge removal }\end{array}$ & A-2 \\
\hline
\end{tabular}


SWMU HSWA

permit

\begin{tabular}{c}
$\begin{array}{c}\text { Unit ID } \\
\text { number }\end{array}$ Unit title $\quad \begin{array}{c}\text { Unit location } \\
\text { description }\end{array}$ \\
\hline
\end{tabular}
History

CERCLA

appendix numbe description

FFA status SWMU note

place and no longer receives water from the fan room sumps.

Water previously entering tank $2101-\mathrm{U}$ has been redirected to tank 2100-U

\section{Tank 2102-U 9204-2E/9215 \{Bldg. 9767-13\} Alley}

$\varpi$
$\stackrel{\omega}{0}$

1266 Tank 2104-U
Tank 2105-U
South of

Bldg. 9201-5

Southeast of Bldg. 9201-5; UEFPC

Subbasin E

West of Bldg. 9202; UEFPC

Subbasin A
This 32,000-gal tank received a methanol/water mixture, used as coolant for the COLEX process, beginning in 1951, and also was used as a settling tank for mercury-contaminated water and sediment from sumps in the basement of Bldg. 9201-5 . In 1993 the sediment in the tank was removed. It was noted that the bypass line was half full of sludge and radioactive contamination. Cracks noted in the tank were sealed with epoxy-type paint in 1993.

Tank 2105-U was used to store beryllium-contaminated wastewater from 1969 to 1984 . The potential exists that the wastewaters were also contaminated with 1,1,1-trichloroethane and tetrachloroethene from production operations. The tank was leak tested in 1988 and found to be competent.
CWA

Permit-by-rule; wastewater settling pit; stored mercury cont. sludge; filled with gravel 1993

Wastewater settling pit; includes UST used for waste coolant

Remedial action complete

Wastewater settling pit; CERCLA ROD 9/26/91 for $\mathrm{Hg}$ contaminated sludge removal

Will be addressed by UEFPC

Filled 5/88, beryllium cont.

Soils and

wastewater sump

\section{A-2}

Scrapyard

ROD 


\begin{tabular}{|c|c|c|c|}
\hline $\begin{array}{l}\text { Unit ID } \\
\text { number }\end{array}$ & Unit title & $\begin{array}{l}\text { Unit location } \\
\text { description }\end{array}$ & History \\
\hline 1268 & Tank 2116-U & $\begin{array}{l}\text { Southwest of } \\
\text { Bldg. 9204-4; } \\
\text { UEFPC } \\
\text { Subbasin I }\end{array}$ & $\begin{array}{l}\text { This underground steel tank was used to store liquid wastes from } \\
\text { the heavy machine shop area of Bldg. } 9204-4 \text {, including solvents, } \\
\text { coolants, and etching wastes that included acetone, caustic } \\
\text { solutions, ketones, toluene, and nitric acid, which may have been } \\
\text { contaminated with uranium and/or thorium. The machine shop } \\
\text { was responsible for machining several materials, including } \\
\text { aluminum, stainless steel, thorium, and some depleted uranium. } \\
\text { The tank received wastes via a series of pipes connected to basins } \\
\text { inside Bldg. } 9204-4 \text {. Wastes stored included Rust-Lick, } \\
\text { water-soluble oil used in the machining of some metals. The tank } \\
\text { was taken out of service in } 1970 \text { but was left in place. In } 1975 \\
\text { piping connecting the tank to Bldg. } 9204-4 \text { was removed, and an } \\
\text { aboveground tank (YS-216) was mounted on the wall of the } \\
\text { building. YS-216 has a containment dike beneath it to contain } \\
\text { spills and leaks. When it was removed in } 1985 \text {, tank } 2116-U \text { was } \\
\text { empty and holes were observed in the steel wall. }\end{array}$ \\
\hline
\end{tabular}

\section{Tank 2284-U}

Tank And

Transfer Station \{Bldg. 9201-5\}

1272 Tank And Transfer Station \{Bldg. 9215\}
South of

This unit was used for underground storage of liquid propane. Bldg. 9735, in The site consists of the 2000-gal steel tank inside a steel-capped UEFPC Sub-basin concrete vault measuring $4 \times 5 \mathrm{ft}$.

\section{$\mathrm{C}$ at $\mathrm{Y}-12$}

South side of

9201-5

\section{5, SW Corner,}

Outside and $\mathrm{Col}$

R-77, Inside
SWMU HSWA

permit

appendix

CERCLA

FFA status

SWMU not

classification $^{a}$

Will be

UST pulled in

A-1(a)

addressed 1985

by UEFPC contaminated

Soils and surrounding

Scrapyard soils, below

ROD YS-216

CWA

Permit-by-rule; mopwater

CWA

Permit-by-rule; mopwater/coola 
Table B.1 (continued)

\begin{tabular}{|c|c|c|c|c|c|c|}
\hline $\begin{array}{l}\text { Unit ID } \\
\text { number }\end{array}$ & Unit title & $\begin{array}{c}\text { Unit location } \\
\text { description }\end{array}$ & History & $\begin{array}{c}\text { CERCLA } \\
\text { FFA status } \\
\end{array}$ & SWMU note & $\begin{array}{c}\text { SWMU HSWA } \\
\text { permit } \\
\text { appendix } \\
\text { classification } \\
\end{array}$ \\
\hline 1273 & $\begin{array}{l}\text { Tank and } \\
\text { Transfer Station } \\
\{\text { Bldg. 9204-4\} }\end{array}$ & $\begin{array}{l}\text { East end of } \\
\text { basement }\end{array}$ & & & $\begin{array}{l}\text { CWA } \\
\text { Permit-by-rule; } \\
\text { aboveground, } \\
\text { mopwater/coola } \\
\text { nt wastewaters; } \\
\text { out of service }\end{array}$ & A-2 \\
\hline 1274 & $\begin{array}{l}\text { Tank } \\
\{\text { Bldg. 9201-1\} }\end{array}$ & $\begin{array}{l}\text { Between } \\
\text { Bldgs. 9720-1 and } \\
\text { 9201-1 }\end{array}$ & & & $\begin{array}{l}\text { CWA } \\
\text { Permit-by-rule; } \\
\text { outside } \\
\text { aboveground; } \\
\text { mopwater }\end{array}$ & A-2 \\
\hline 1275 & $\begin{array}{l}\text { Tank } \\
\text { \{Bldg. 9201-5E }\}\end{array}$ & $\begin{array}{l}\text { NE of 9201-5, } \\
\text { between } \\
\text { Bldg. } 9622 \text { and } \\
\text { 1st Street }\end{array}$ & & & $\begin{array}{l}\text { CWA } \\
\text { Permit-by-rule; } \\
\text { used for electro } \\
\text { chemical } \\
\text { machine } \\
\text { wastewater }\end{array}$ & A-2 \\
\hline
\end{tabular}




\begin{tabular}{|c|c|c|c|c|c|c|}
\hline $\begin{array}{l}\text { Unit ID } \\
\text { number }\end{array}$ & Unit title & $\begin{array}{c}\text { Unit location } \\
\text { description }\end{array}$ & History & $\begin{array}{c}\text { CERCLA } \\
\text { FFA status } \\
\end{array}$ & SWMU note & $\begin{array}{l}\text { SWMU HSWA } \\
\text { permit } \\
\text { appendix } \\
\text { classification }^{a}\end{array}$ \\
\hline 1276 & $\begin{array}{l}\text { Tank } \\
\{\text { Bldg. 9202\} }\end{array}$ & $\begin{array}{l}\text { Building 9202, } \\
\text { East Side }\end{array}$ & & & $\begin{array}{l}\text { CWA } \\
\text { Permit-by-rule; } \\
\text { wastewater } \\
\text { collection tank }\end{array}$ & A-2 \\
\hline 1277 & $\begin{array}{l}\text { Tank } \\
\text { \{Bldg. 9204-2 } \\
\text { NE Corner }\end{array}$ & $\begin{array}{l}\text { Building 9204-2, } \\
\text { Outside, NE } \\
\text { Corner }\end{array}$ & & & $\begin{array}{l}\text { CWA } \\
\text { Permit-by-rule; } \\
\text { used for } \\
\text { mopwater, } \\
\text { previously } \\
\text { relocated }\end{array}$ & A-2 \\
\hline 1278 & $\begin{array}{l}\text { Tank } \\
\{\text { Bldg. 9204-4\} }\end{array}$ & $\begin{array}{l}\text { Near northeast } \\
\text { corner of } \\
\text { Bldg. 9204-4; } \\
\text { UEFPC } \\
\text { Subbasin H }\end{array}$ & $\begin{array}{l}\text { This tank has been used since } 1987 \text { to store dilute cyanide rinse } \\
\text { water. There are no documented releases from this site; and, } \\
\text { because of the secondary containment structure, it is not } \\
\text { considered a likely source of contamination to UEFPC. }\end{array}$ & $\begin{array}{l}\mathrm{RI} / \mathrm{FS} \text { in } \\
\text { progress }\end{array}$ & $\begin{array}{l}\text { CWA } \\
\text { Permit-by-rule }\end{array}$ & A-2 \\
\hline 1279 & $\begin{array}{l}\text { Tank } \\
\{\text { Bldg. 9206\} }\end{array}$ & 9206, West Yard & & & $\begin{array}{l}\text { CWA } \\
\text { Permit-by-rule }\end{array}$ & A-2 \\
\hline 1280 & $\begin{array}{l}\text { Tank } \\
\text { \{Bldg. 9720-22\} }\end{array}$ & $\begin{array}{l}\text { Located on SW } \\
\text { side of } \\
\text { Bldg. 9204-4 }\end{array}$ & & & $\begin{array}{l}\text { Aboveground, } \\
\text { used for } \\
\text { wastewater } \\
\text { storage, out of } \\
\text { service }\end{array}$ & A-2 \\
\hline 1281 & $\begin{array}{l}\text { Tank } \\
\{\text { Bldg. 9818\} }\end{array}$ & $\begin{array}{l}\text { Basement of } \\
\text { Bldg. } 9818 \text { at } \\
\text { Y-12 }\end{array}$ & The tank has been used for storage of miscellaneous acid wastes. & $\begin{array}{l}\text { Will be } \\
\text { addressed } \\
\text { by UEFPC } \\
\text { Soils and } \\
\text { Scrapyard } \\
\text { ROD }\end{array}$ & $\begin{array}{l}\text { CWA } \\
\text { Permit-by-rule; } \\
\text { stored misc. } \\
\text { acidic wastes }\end{array}$ & A-2 \\
\hline
\end{tabular}




\begin{tabular}{|c|c|c|c|c|c|c|}
\hline $\begin{array}{l}\text { Unit ID } \\
\text { number }\end{array}$ & Unit title & $\begin{array}{c}\text { Unit location } \\
\text { description }\end{array}$ & History & $\begin{array}{c}\text { CERCLA } \\
\text { FFA status }\end{array}$ & SWMU note & $\begin{array}{l}\text { SWMU HSWA } \\
\text { permit } \\
\text { appendix } \\
\text { classification }^{a}\end{array}$ \\
\hline 1282 & $\begin{array}{l}\text { Tank }\{\text { Near } \\
9401-2\}\end{array}$ & $\begin{array}{l}\text { Between } \\
\text { Bldgs. 9416-7 and } \\
9401-2\end{array}$ & & & $\begin{array}{l}\text { CWA } \\
\text { Permit-by-rule; } \\
\text { Aboveground, } \\
\text { used for plating } \\
\text { rinse solutions }\end{array}$ & A-2 \\
\hline 1283 & $\begin{array}{l}\text { Tank }\{\text { S of } \\
\text { Bldg. } 9201-5 N\}\end{array}$ & $\begin{array}{l}\text { SW of Bldg } \\
9201-5 N \text {, adj. to } \\
\text { sidewalk and 1st } \\
\text { Street }\end{array}$ & & & $\begin{array}{l}\text { CWA } \\
\text { Permit-by-rule; } \\
\text { aboveground } \\
\text { used for plating } \\
\text { rinsewaters }\end{array}$ & A-2 \\
\hline 1284 & $\begin{array}{l}\text { Tank }\{\text { SW of } \\
\text { Bldg. } 9201-5 \mathrm{~N}\}\end{array}$ & $\begin{array}{l}\text { SW of Bldg } \\
9201-5 N \text {, adj. to } \\
\text { sidewalk and 1st } \\
\text { Street }\end{array}$ & & & $\begin{array}{l}\text { CWA } \\
\text { Permit-by-rule; } \\
\text { aboveground, } \\
\text { detergent } \\
\text { solution }\end{array}$ & A-2 \\
\hline 1285 & $\begin{array}{l}\text { Tank/Transfer } \\
\text { Station } \\
\text { \{Bldg. 9201-5W } \\
\text { SW End }\end{array}$ & $\begin{array}{l}\text { Building 9201-5 } \\
\text { W, SW Corner }\end{array}$ & & & $\begin{array}{l}\text { CWA } \\
\text { Permit-by-rule; } \\
\text { aboveground, } \\
\text { mopwater/coola } \\
\text { nt wastewater }\end{array}$ & A-2 \\
\hline 1286 & $\begin{array}{l}\text { Tank/Transfer } \\
\text { Station } \\
\text { \{Bldg. 9204-2E }\}\end{array}$ & $\begin{array}{l}\text { 9204-2E/9215 } \\
\text { Alley }\end{array}$ & & & $\begin{array}{l}\text { CWA } \\
\text { Permit-by-rule; } \\
\text { Diked in } 1986\end{array}$ & A-2 \\
\hline 1287 & $\begin{array}{l}\text { Tank/Transfer } \\
\text { Station }\{\text { Near } \\
9204-4\}\end{array}$ & $\begin{array}{l}\text { Adjacent to and } \\
\text { southwest of } \\
\text { Bldg. 9204-4 }\end{array}$ & & & $\begin{array}{l}\text { CWA } \\
\text { Permit-by-rule; } \\
\text { Atop YS-214 }\end{array}$ & A-2 \\
\hline
\end{tabular}




\begin{tabular}{|c|c|c|c|c|c|c|}
\hline $\begin{array}{l}\text { Unit ID } \\
\text { number }\end{array}$ & Unit title & $\begin{array}{l}\text { Unit location } \\
\text { description }\end{array}$ & History & $\begin{array}{l}\text { CERCLA } \\
\text { FFA status }\end{array}$ & SWMU note & $\begin{array}{l}\text { SWMU HSWA } \\
\text { permit } \\
\text { appendix } \\
\text { classification }^{a}\end{array}$ \\
\hline 1289 & $\begin{array}{l}\text { Tanks and } \\
\text { Transfer Station } \\
\{\text { Bldg. 9201-5 }\end{array}$ & $\begin{array}{l}\text { Inside } 9201-5, \mathrm{SE} \\
\text { Corner }\end{array}$ & & & $\begin{array}{l}\text { CWA } \\
\text { Permit-by-rule; } \\
3 \text { Tanks inside } \\
\text { building; used } \\
\text { for multiple } \\
\text { wastes, coolant }\end{array}$ & A-2 \\
\hline 1290 & $\begin{array}{l}\text { Tanks and } \\
\text { Transfer Station } \\
\text { \{Bldg. 9204-4\} }\end{array}$ & $\begin{array}{l}\text { Inside the east end } \\
\text { of Bldg. 9204-4; } \\
\text { UEFPC } \\
\text { Subbasin H }\end{array}$ & $\begin{array}{l}\text { This facility was used beginning in } 1955 \text { for the treatment/storage } \\
\text { of rinse water from plating operations. The date this tank was } \\
\text { taken out of service is not known. Historically, spills have been } \\
\text { contained within the building; however, there is a floor drain that } \\
\text { connects to the storm drain system. }\end{array}$ & & $\begin{array}{l}\text { CWA } \\
\text { Permit-by-rule; } \\
\text { empty as of } \\
1995\end{array}$ & A-2 \\
\hline 1292 & $\begin{array}{l}\text { Third Street Soil } \\
\text { Pile }\end{array}$ & $\begin{array}{l}\text { On top of 9409-3 } \\
\text { Cooling Tower } \\
\text { Basin (YS-124); } \\
\text { UEFPC } \\
\text { Subbasin A }\end{array}$ & $\begin{array}{l}\text { From } 1984 \text { to } 1988 \text {, a } 500 \text { cy mercury-contaminated soil pile was } \\
\text { temporarily stored on top of the filled and asphalt-covered } \\
\text { Bldg. } 9409-3 \text { Cooling Tower Basin (YS-124). The pile rested on } \\
\text { the asphalt and was covered with plastic sheeting. The soil was } \\
\text { removed and placed in the CRSDB before it was closed. }\end{array}$ & $\begin{array}{l}\text { Will be } \\
\text { address in } \\
\text { UEFPC } \\
\text { Soils and } \\
\text { Scrapyard } \\
\text { ROD }\end{array}$ & $\begin{array}{l}\mathrm{Hg} \\
\text { contaminated } \\
\text { soil, moved to } \\
\text { YD-025 }\end{array}$ & A-1(a) \\
\hline 1294 & $\begin{array}{l}\text { Upper East Fork } \\
\text { Poplar Creek } \\
\text { (UEFPC) } \\
\text { Sediments }\end{array}$ & $\begin{array}{l}\text { On the south and } \\
\text { east ends of the } \\
\text { Y-12 Plant }\end{array}$ & $\begin{array}{l}\text { The Y-12 Plant, an 800-acre facility, was built in } 1943 \text { as part of } \\
\text { the Manhattan Project and was originally involved in uranium } \\
\text { enrichment. The plant is a manufacturing and developmental } \\
\text { engineering facility that produced components for various nuclear } \\
\text { weapons systems and provides engineering support for other Energy } \\
\text { Systems facilities. UEFPC flows along the southern and eastern } \\
\text { ends of the Y-12 Plant and receives runoff from subbasins A-K. }\end{array}$ & $\begin{array}{l}\text { RI/FS in } \\
\text { progress; } \\
\text { includes } \\
\text { surface } \\
\text { water }\end{array}$ & $\begin{array}{l}\mathrm{Hg} \\
\text { contamination } \\
\text { from historical } \\
\text { spills/leakage }\end{array}$ & Historical \\
\hline 1296 & $\begin{array}{l}\text { Uranium } \\
\text { Treatment Unit } \\
\text { (IS-48) }\end{array}$ & $\begin{array}{l}\text { Building } 9206 \text {, } \\
\text { East Dock }\end{array}$ & & & $\begin{array}{l}\text { RCRA clean } \\
\text { closed } 1996\end{array}$ & A-2 \\
\hline 1298 & $\begin{array}{l}\text { Waste Coolant } \\
\text { Processing }\end{array}$ & $\begin{array}{l}\text { South of } \\
\text { Bldg. 9204-4, west }\end{array}$ & & & $\begin{array}{l}\text { CWA } \\
\text { Permit-by-rule }\end{array}$ & A-2 \\
\hline
\end{tabular}




\begin{tabular}{|c|c|c|c|c|c|c|}
\hline $\begin{array}{l}\text { Unit ID } \\
\text { number }\end{array}$ & Unit title & $\begin{array}{c}\text { Unit location } \\
\text { description }\end{array}$ & History & $\begin{array}{c}\text { CERCLA } \\
\text { FFA status }\end{array}$ & SWMU note & $\begin{array}{c}\text { permit } \\
\text { appendix } \\
\text { classification }^{a}\end{array}$ \\
\hline 1299 & $\begin{array}{l}\text { Waste Machine } \\
\text { Coolant } \\
\text { Biodegradation } \\
\text { Facility }\end{array}$ & $\begin{array}{l}\text { South of } \\
\text { Bldg. 9204-4; } \\
\text { UEFPC } \\
\text { Subbasin H }\end{array}$ & $\begin{array}{l}\text { The facility consists of three } 14,000 \text {-gal storage tanks (tanks } \\
2065-\mathrm{U}, 2066-\mathrm{U} \text {, and } 2067-\mathrm{U} \text { ), a feed tank, a } 30,000 \text {-gal elevated } \\
\text { concrete reactor and settling basin, two steel sludge evaporation } \\
\text { tanks, miscellaneous piping, and two } 40-\text { by } 40 \text {-ft tile drain fields. } \\
\text { The storage tanks and feed tank are addressed as a separate unit } \\
\text { (YS-022). The site was clean closed in August } 1988 \text { per RCRA }\end{array}$ & $\begin{array}{l}\text { Will be } \\
\text { addressed } \\
\text { in UEFPC } \\
\text { Soils and } \\
\text { Scrapyard } \\
\text { ROD }\end{array}$ & $\begin{array}{l}\text { RCRA clean } \\
\text { closure 11/88; } \\
\text { groundwater } \\
\text { cont. deferred to } \\
\text { CERCLA }\end{array}$ & A-1(a) \\
\hline
\end{tabular}

requirements. This facility was used from 1977 through

December 1985 to treat waste machine coolants containing up to $100,000 \mathrm{ppm}$ total organic carbon (TOC); up to several

thousand ppm chlorinated organics; up to several thousand ppm methyl ethyl ketone; EP Tox metals; and depleted uranium. In

1985 a new waste coolant processing facility was completed.

Releases from this site have been documented. Waste machine

coolant was transported to this facility in tankers, discharged into three concrete unloading pits, which drained to sumps, then was pumped to an 8000-gal tank located near the reactor. The

biological reactor was a converted cooling tower basin and was equipped with four 5-hp floating aerators, which both aerated and mixed the reactor solution. Adjacent to the reactor, a second 2000-gal basin was baffled to serve as a settling tank for the bacterial mass (sludge). A small submersible pump, activated by an electrical timer in the settling basin, recycled the settled bacterial mass every 30 minutes. Liquid effluent (supernatant) from the settling tank discharged into an underground drain field located adjacent to the facility. Closure wastes were sent to the Interim Drum Yard (YS-030). Documented spills have occurred from the aeration basin and appurtenances. Effluent was discharged to a tile drainfield. Releases from the tile drainfield may have contaminated groundwater. 
ite is located at the east end or the $\mathrm{Y}-12$ site near

Scarboro Road

1305 Z-oil Contaminated Areas

\{abandoned equip, piping
Machining collant distribution system. Contaminated equipment and piping were removed in 2003 as part of the Y-12

Infrastructure reduction program.
SWMU HSWA

permit

appendix

CERCLA

FFA status

SWMU note

classification $^{a}$

Solid waste

compactor and

storage

RCRA Permit

(TNHW 032);

also PCB storage

(TS-06). RCRA

clean closure

TDEC certified

$11 / 6 / 01$.

Lead

contaminated

soils; CERCLA

removal action

completed 1998 ,

Removal Action

Report approved

2/23/99

Suspected cont. from historical

passive leakage
A-2 


\begin{tabular}{|c|c|c|c|c|c|c|}
\hline $\begin{array}{l}\text { Unit ID } \\
\text { number }\end{array}$ & Unit title & $\begin{array}{c}\text { Unit location } \\
\text { description }\end{array}$ & History & $\begin{array}{c}\text { CERCLA } \\
\text { FFA status } \\
\end{array}$ & SWMU note & $\begin{array}{c}\text { SWMU HSWA } \\
\text { permit } \\
\text { appendix } \\
\text { classification }^{a} \\
\end{array}$ \\
\hline 1317 & $\begin{array}{l}\text { Tank } \\
\{\text { Bldg. 9204-4\} }\end{array}$ & $\begin{array}{l}\text { Northeast corner } \\
\text { of Bldg. 9204-4 }\end{array}$ & & & $\begin{array}{l}\text { Stored } \\
\text { corrosives; tank } \\
\text { removed }\end{array}$ & A-2 \\
\hline 1318 & $\begin{array}{l}\text { Tank } \\
\{\text { Bldg. 9204-4\} }\end{array}$ & $\begin{array}{l}\text { Northeast corner } \\
\text { of Bldg. 9204-4 }\end{array}$ & & & $\begin{array}{l}\text { Former 90-day } \\
\text { accumulation } \\
\text { tank; tank } \\
\text { removed }\end{array}$ & A-2 \\
\hline 1319 & $\begin{array}{l}\text { Tank /Transfer } \\
\text { Station } \\
\text { \{Bldg. 9204-2E\} }\end{array}$ & $\begin{array}{l}\text { 9204-E/9215 } \\
\text { Alley }\end{array}$ & & & $\begin{array}{l}\text { CWA } \\
\text { Permit-by-rule; } \\
\text { Diked in } 1986\end{array}$ & A-2 \\
\hline 1320 & $\begin{array}{l}\text { Tank /Transfer } \\
\text { Station } \\
\text { \{Bldg. 9204-2E\} }\end{array}$ & $\begin{array}{l}\text { 9204-2E/9215 } \\
\text { Alley }\end{array}$ & & & $\begin{array}{l}\text { CWA } \\
\text { Permit-by-rule; } \\
\text { Diked in } 1986\end{array}$ & A-2 \\
\hline 1321 & $\begin{array}{l}\text { Tank /Transfer } \\
\text { Station } \\
\text { \{Bldg. 9204-2E\} }\end{array}$ & $\begin{array}{l}\text { 9204-2E/9215 } \\
\text { Alley }\end{array}$ & & & $\begin{array}{l}\text { CWA } \\
\text { Permit-by-rule; } \\
\text { Diked in } 1986\end{array}$ & A-2 \\
\hline 1322 & $\begin{array}{l}\text { Tank/Transfer } \\
\text { Station } \\
\text { \{Bldg. 9201-5\} }\end{array}$ & $\begin{array}{l}\text { South side of } \\
9201-5\end{array}$ & & & $\begin{array}{l}\text { CWA } \\
\text { Permit-by-rule; } \\
\text { mopwater }\end{array}$ & A-2 \\
\hline 1323 & $\begin{array}{l}\text { Tank } \\
\text { \{Bldg. 9204-4\} }\end{array}$ & $\begin{array}{l}\text { 9204-4, Northeast } \\
\text { corner of building }\end{array}$ & & & $\begin{array}{l}\text { CWA } \\
\text { Permit-by-rule; } \\
\text { aboveground, } \\
\text { plating } \\
\text { rinsewaters }\end{array}$ & A-2 \\
\hline 1435 & $\begin{array}{l}\text { Bldg. 9720-59 } \\
\text { (Classified Waste } \\
\text { Storage Unit) } \\
\text { (PER-57) }\end{array}$ & Building 9720-59 & & & $\begin{array}{l}\text { RCRA permit } \\
\text { (TNHW-092) }\end{array}$ & A-2 \\
\hline
\end{tabular}


Table B.1 (continued)

SWMU HSWA

permit

appendix

\begin{tabular}{|c|c|c|c|c|c|c|}
\hline $\begin{array}{l}\text { Unit ID } \\
\text { number }\end{array}$ & Unit title & $\begin{array}{l}\text { Unit location } \\
\text { description }\end{array}$ & History & $\begin{array}{c}\text { CERCLA } \\
\text { FFA status }\end{array}$ & SWMU note & $\begin{array}{c}\text { appendix } \\
\text { classification }^{a}\end{array}$ \\
\hline 1526 & $\begin{array}{l}\text { UEFPC Firing } \\
\text { Range }\end{array}$ & & & $\begin{array}{l}\text { RmA } \\
\text { Report } \\
\text { approved. }\end{array}$ & & \\
\hline 1527 & $\begin{array}{l}\text { UEFPC East End } \\
\text { VOC Plumes }\end{array}$ & & & $\begin{array}{l}\text { RmAWP } \\
\text { approved. }\end{array}$ & & \\
\hline 1528 & $\begin{array}{l}\text { Union Valley } \\
\text { Groundwater } \\
\text { Plume }\end{array}$ & TBD & & & & \\
\hline 1552 & $\begin{array}{l}\text { Y-12 Water } \\
\text { Treatment Plant } \\
\text { Study Area (\#4c) }\end{array}$ & Not Available & & 130 acres & & \\
\hline 1627 & $\begin{array}{l}\text { Arboretum } \\
\text { Spring }\end{array}$ & & & & & \\
\hline 1633 & $\begin{array}{l}\text { Building } 9212 \\
\text { Groundwater } \\
\text { Plume }\end{array}$ & $\begin{array}{l}\text { Building } 9212 \text { is } \\
\text { located in the } \\
\text { northcentral } \\
\text { portion of the } \\
\text { Y-12 Plant south } \\
\text { of Bear Creek } \\
\text { Road }\end{array}$ & & & & \\
\hline
\end{tabular}

1634 Fire Training

Area

Groundwater

Plume 


\begin{tabular}{|c|c|c|}
\hline $\begin{array}{l}\text { Unit ID } \\
\text { number }\end{array}$ & Unit title & $\begin{array}{c}\text { Unit location } \\
\text { description }\end{array}$ \\
\hline 1635 & $\begin{array}{l}\text { Storm Sewer } \\
\text { Contaminated } \\
\text { Sediments }\end{array}$ & $\begin{array}{l}\text { Sections of storm } \\
\text { sewer in the West } \\
\text { End Mercury } \\
\text { Area of the Y-12 } \\
\text { NSC } \\
\text { approximately } \\
\text { located between } \\
\text { Outfalls } 169 \text { and } \\
150\end{array}$ \\
\hline
\end{tabular}

1637 Building 9201-4

External Pipes

\begin{abstract}
2327 Salvage Yard
\end{abstract}
Oil/Solvent Drum Storage

Storage Area

south of

[East and West] Bldg. 9114,

portions of the site are located east and west of the PIDAS
The site consists of two uncovered drum storage areas, one to the
east and one to the west, where the drums sat on a compacted gravel/soil base. Each area had a clay and gravel berm, which contains most of the east, south, and west sides. An RI was prepared to address the entire Salvage Yard area, including YS-018, YS-020, YT-109, YS-111, and YS-204, but it was not implemented. Drummed waste oils and solvents were stored on pallets before disposal. There are documented releases from the drums, and Appendix VIII constituents have been detected in soil samples collected from the storage area. The western storage area completed closure in November 1986, and the eastern portion was closed in 1988. As a result, all drums were removed to other Y-12 facilities, soils and gravel in the eastern portion were excavated to a depth of 1 to $2 \mathrm{ft}$ (September and December 1988), and the dike was removed. The area was then filled with clean clay fill and a polyethylene membrane was placed over the clay. Earlier in 1988, a 50-ft-wide PIDAS corridor was cleared, which necessitated the removal and backfill of $5 \mathrm{ft}$ of soil through the western side of the storage area. The Tennessee Department of Health and Environment (now TDEC) approved closure of the
SWMU HSWA

permit

appendix
classification

CERCLA

FFA status

SWMU note
Includes RCRA clean

soils. Will closure for

be

addressed constituents

in UEFPC 1989; remaining

Soils and contamination

Scrapyard deferred to

ROD CERCLA
A-1(a) 


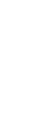

east area after review of the soil and groundwater data from in and around the facility that showed arsenic levels below ORR background levels and PCB levels below health-based criteria. 9-13-99: The CERCLA Area "Salvage Yard Oil/Solvent Drum Storage Area Contaminated Soils" was rolled up into this CERCLA Area.

2328 Salvage Yard Scrap Metal Storage Area
2330 S-2 Site (Surface The S-2 Site is Impoundment)
The site is located south of Bldg. 9114 and is bisected by the PIDAS corridor

This site is a non-RCRA storage area for scrap metal, some with Include low levels of depleted and/or enriched uranium, PCB, asbestos, or soils. beryllium contamination. Scrap metals were collected, monitored, segregated by type of contamination, stored, and sold. Now, scrap is shipped to a smelter, but in the past, uncontaminated scrap metal was sold to the public. Construction of the 50-ft-wide PIDAS corridor necessitated the removal and backfill of the top $5 \mathrm{ft}$ of soil throughout the length of this area. Areas of visual contamination scattered throughout the site have been documented by site visits and aerial photos. These discolored soils have been noted and appear to be from one-time releases, rather than continuing releases from permanent sources. There are documented releases from this site. 9-13-99: The CERCLA Area "Salvage Yard Scrap Metal Storage Area and Contaminated Soils" was rolled up into this CERCLA Area.

This unlined earthen reservoir was used from 1943 to 1951 for the disposal of corrosive and toxic aqueous wastes, possibly halogenated and nonhalogenated solvents. There are no documented releases from this site; however, due to the process activities, lack of containment structures, and known

southwestern portion of the Y-12 area, south of Bldg. 9720-32 contaminants at the site, releases are likely to have occurred. The site consisted of a disposal pit, 45 by $128 \mathrm{ft}$ at the base and 93 by $143 \mathrm{ft}$ at the crest. The disposal pit was $20 \mathrm{ft}$ deep (bottom elevation $987 \mathrm{ft} \mathrm{msl}$ ) and was excavated into the hillside. The depth to bedrock in this area is $25-40 \mathrm{ft}$. The S-2 Site was closed
Suspected

contaminated soils beneath pile

Closed filled neutralized and groundwater cont. deferred to CERCLA. 
SWMU HSWA

CERCLA

in 1951 by neutralizing the liquids and backfilling the reservoir

in 1951 by neutralizing the liquids and backfilling the reservoir
with soil. After backfill was complete, the site was covered with $24 \mathrm{ft}$ of topsoil, leveled, and seeded with grass.

\section{Salvage Yard} Drum Deheader
This site was located in the Salvage Yard in brick

Building south of Bldg. 9114
This non-RCRA treatment facility was operated from 1959 to

March 1989, and consisted of a drum deheader and a drum

crusher that were removed in 1991. The drum deheader was located in the center of a 13.3 by 10 by $8.7 \mathrm{ft}$ tall brick building, with a concrete floor and a fan in the center of one wall. A floor drain led from the area of the drum crusher to several tanks

(YS-204). An RI work plan was prepared, but never implemented to address the entire Salvage Yard area, including YS-018,

YS-020, YT-109, YS-111, and YS-204. Drums containing up to an inch of oil and solvents were emptied into a drum that was placed into a concrete block tank (tank 2063-U). Emptied drums not suitable for re-use were crushed and placed into a portable scrap hopper. The crushed drums were taken to the Bear Creek Burial Grounds or the sanitary landfill, depending on the material they contained. The deheading and crushing both caused release of residual liquid wastes, which initially drained into tanks 2328-U and 2329-U. In 1979 the floor drains were plugged, and residual liquids were then captured with absorbent materials.

There are no documented releases from this site; however, the area is contaminated and practice from the early years of operation may not have prevented the spread of contamination. 9-13-99: CERCLA Area "Salvage Yard Drum Deheader Contaminated Soils" rolled up into this CERCLA Area.
FFA status

SWMU note
Includes

soils. Will

be

addressed

in the

UEFPC

Soils and Scrapyard ROD
Deheader

removed 1991

and included 2

sumps 


\begin{tabular}{|c|c|c|}
\hline $\begin{array}{l}\text { Unit ID } \\
\text { number }\end{array}$ & Unit title & $\begin{array}{l}\text { Unit location } \\
\text { description }\end{array}$ \\
\hline 2340 & $\begin{array}{l}\text { Building 81-10 } \\
\text { Area \{Former Hg } \\
\text { Roaster\} } \\
\text { Contaminated } \\
\text { Soils }\end{array}$ & $\begin{array}{l}\text { East of } 9720-9 \\
\text { and south of } \\
\text { UEFPC on the } \\
\text { original creek } \\
\text { channel }\end{array}$ \\
\hline
\end{tabular}

2483 Upper East Fork Poplar Creek (UEFPC)

Sediments

Soils

2657 Building 9815 Organic Handling Unit (PER-59)

2792 East End Fuel Station Groundwater
Building 9815

Located in the eastern portion of Y-12 near Bldg. 9754-2 in the vicinity of the East End Garage, a former fuel storage and distribution facility.
The Y-12 Plant, an 800-acre facility, was built in 1943 as part of the Manhattan Project and was originally involved in uranium enrichment. The plant is a manufacturing and developmental engineering facility that produced components for various nuclear weapons systems and provides engineering support for other Energy Systems facilities. UEFPC flows along the southern and eastern ends

of the Y-12 Plant and receives runoff from Subbasins A-K.

CERCLA

FFA status

See Bldg. 81-10 Area \{Former Hg Roaster\}

\section{$\mathrm{RI} / \mathrm{FS}$ in}

progress.

RCRA Permit

(TNHW-084)

This site is located north of the former Bldg. 9754 and was the location of three metal USTs. This site was part of a fueling and service station (Bldg. 9754) built in 1945. The original construction consisted of two 10,000-gal tanks for the storage of leaded gasoline and diesel fuel. The tanks were installed on a concrete slab, below grade, inside an earthen dike with space for an additional tank. The third tank, a 20,000-gal unit, was installed in 1974 for the storage of unleaded gasoline. These three tanks gravity fed three 1000-gal holding tanks (YS-506, YS-507, and YS-508) and two emergency dispensers near Bldg. 9754 through fiberglass piping. In 1977, a new gasoline filling station was constructed west of Bldg. 9754 that included new fuel storage tanks. Consequently, use of the 
SWMU HSWA

permit

appendix
classification \begin{tabular}{c}
$\begin{array}{c}\text { Unit ID } \\
\text { number }\end{array} \quad$ Unit title $\quad \begin{array}{c}\text { Unit location } \\
\text { description }\end{array}$ \\
\hline
\end{tabular}

CERCLA

garage USTs for storing gasoline and diesel fuel was discontinued.

FFA status

At the same time, the three 1000-gal holding tanks were emptied

and abandoned, and the emergency dispensers were taken out of service. Beginning in 1980, the three tanks in YS-019 were used to store waste oils. A tank inspection before closure observed no signs of leakage and indicated no staining or cracking of the concrete pad beneath the tanks. The tanks were removed in October 1989. The site was clean closed in 1994. As part of the clean closure it was remediated for cadmium in soils.

Approximately 40 drums of soil were removed from the site. All other clean closure criteria had been met. The west tank

(20,000 gal, previously used for unleaded gasoline) and the middle tank (10,000 gal, previously used for leaded gasoline) have stored

RCRA waste oils containing spent solvents (perchloroethylene and Freon-113) and contaminated with PCBs as well as uranium. These two tanks were closed per RCRA. The third tank $(10,000$ gal, previously used for diesel fuel), located to the east, was used for storage of non-RCRA waste oil and was closed per TSCA. It is unclear whether the piping from the garage USTs to the holding tanks was removed or dismantled before the use of the garage

USTs to store used oils. Available data show that groundwater near the East End Garage are contaminated with petroleum related compounds and chlorinated organics. A contaminant plume can be clearly distinguished.

\section{UEFPC \\ Groundwater}

2794 UEFPC Soils
TBD

TBD 


\begin{tabular}{|c|c|c|}
\hline $\begin{array}{l}\text { Unit ID } \\
\text { number }\end{array}$ & Unit title & $\begin{array}{c}\text { Unit location } \\
\text { description }\end{array}$ \\
\hline 15 & $\begin{array}{l}\text { Bear Creek } \\
\text { Burial Grounds } \\
\text { Groundwater } \\
\text { Plume }\end{array}$ & $\begin{array}{l}\text { Bear Creek } \\
\text { Valley, from Y-12 } \\
\text { Plant to East Fork } \\
\text { Poplar Creek }\end{array}$ \\
\hline
\end{tabular}

17 Bear Creek

Groundwater

18 Bear Creek

Tributary 3

Floodplain Soils

23 S-3 Ponds

Bear Creek

Valley, emanating

from closed S-3

Ponds
The S-3 Ponds source area consists of four unlined ponds formerly used for industrial waste treatment, which were neutralized, drained, filled, and capped during RCRA closure in 1988. From 1951 to 1976, the ponds received liquid wastes from the uranium operations at the Y-12 Plant. Wastes from areas in the plant handling enriched uranium constituted the largest volumes (about 2 million gal of liquid per year). These liquids were sent to the ponds through the pipeline in small batches (about 200 gal). Of the total waste stream, about 1.5 million gal

SWMU HSWA

permit

appendix

CERCLA

FFA status

SWMU note

classification

\section{Bear Creek Watershed}

The Oak Ridge Y-12 Plant was built by the U.S. Army Corps of

RI

approved;

deferred to

a future

decision.
Contamination

from historical

disposal

operations

Historical economical gaseous diffusion process conducted at the nearby Oak Ridge K-25 Site. The area has continued to function a part of DOE operations, including reclamation and storage of of components for the nation's defense capabilities, support to national security programs, and services provided to other ustomers as approved by DOE. Primary contributors to -3 Ponds, Burn Yard-Bone Yard, Oil Landfarm, Sanitary Landfill 1, and Bear Creek Burial Ground. 
SWMU HSWA

per year were called "condensate" and were 0.1 to $4.0 \%$ nitric

acid aqueous solutions. The other stream $(500,000$ gal per year) was "raffinate" and was a mixture of about $20 \%$ aluminum nitrite in 1 to $4 \%$ nitric acid aqueous solutions. During the 1950 s to 1970 s, the uranium assay in the ponds was monitored carefully. Depleted uranium nitrate solution (30\% uranium nitrate aqueous) was pumped through the pipeline to the ponds to maintain an assay of $<0.7 \%{ }^{235} \mathrm{U}$. The ponds generally had an assay of $<0.4 \%$ ${ }^{235} \mathrm{U}$. The volume of this stream was usually 1900 to $3800 \mathrm{~L}$ (500 to 1000 gal) per year and was generated from spent pickle baths used for cleaning depleted uranium metal. The acid cleaning bath also was occasionally used for cleaning copper metal, but this was not a common practice. In 1976, a recycle and nitrate recovery system was developed and installed for the condensate and raffinate streams. The amounts of nitrate that were being released to the ponds from the plant decreased significantly, but the volumes of waste liquids going to the ponds remained approximately the same. However the amounts of depleted uranium being released did not decrease. During the late 1970s, mop waters (soap and water) that had previously been discharged in BCBG were diverted to the S-3 Ponds. This waste stream reportedly did not contain any uranium. In the late 1970s and early 1980s, the ponds received sludge from the scrubbing of waste fluoride gas from the K-25 Site. The sludge was a mixture of potassium carbonate, potassium hydroxide, and potassium fluoride with a small amount of ${ }^{99} \mathrm{Tc}$. The sludge contained about $40 \%$ solids and $60 \%$ water. Liquid waste discharges into the ponds were terminated in March 1984. While in operation, the now-abandoned nitric acid pipeline also transported liquid wastes originating from sources outside of Oak Ridge Y-12 Plant,

including raffinate from DOE's Savannah River Site and Idaho National Engineering Laboratory. The wastes from these facilities 
contained, at a minimum, the following radionuclides: ${ }^{137} \mathrm{Cs},{ }^{57} \mathrm{Co}$

and ${ }^{60} \mathrm{Co}$, californium, americium, iodine isotopes, ${ }^{237} \mathrm{~Np},{ }^{95} \mathrm{Nb}$ nickel isotopes, ${ }^{238} \mathrm{Pu}$ and ${ }^{239} \mathrm{Pu},{ }^{106} \mathrm{Ru},{ }^{90} \mathrm{Sr},{ }^{228} \mathrm{Th},{ }^{230} \mathrm{Th},{ }^{232} \mathrm{Th}$, ${ }^{234} \mathrm{Th},{ }^{99} \mathrm{Tc},{ }^{95} \mathrm{Zr}$, and uranium daughters. These radionuclides were present in the waste streams in the parts per billion (ppb) range and possibly the low parts per million ( $\mathrm{ppm}$ ) range. The ponds also received liquid waste from the K-25 Site and Oak Ridge National Laboratory in Oak Ridge, but these were transported by truck in small batches (usually in 55-gal drums). Several studies of water and sludges in the S-3 Ponds concluded that, although the pond water chemistry varied from pond to pond and from year to year, it generally remained highly acidic. Nitric acid was the primary acid constituent. Major metallic ion constituents were calcium, magnesium, potassium, aluminum; moderately high concentrations of other trace metals were present. The few organic analyses available for the pond waters indicate that concentrations of organics could have been highly variable over the period of operation. In situ treatment of wastewater in the S-3 Ponds consisted of (1) neutralization in all four ponds between May and November 1983 and (2) in situ biodenitrification processes from May 1983 to September 1984. This biodenitrification treatment decreased nitrate levels in the pond water to $<50 \mathrm{ppm}$. Nutrients continued to be added to the ponds.

497 C-14 Allocation In White Oak Trees
Located 1.9 miles on an azimuth of N 25 E from the intersection of Bethel Valley an
M. Valley Rd.
Two studies were conducted in this area. The purpose of the first was to determine seasonal changes in photosynthate translocation and allocation by following the rates of movement of the C-14 from labeled foliage, and the second was to follow the rate and efficiency of the utilization of food reserves. (Taylor 1986) 


\begin{tabular}{|c|c|c|c|c|c|c|}
\hline $\begin{array}{l}\text { Unit ID } \\
\text { number }\end{array}$ & Unit title & $\begin{array}{c}\text { Unit location } \\
\text { description }\end{array}$ & History & $\begin{array}{c}\text { CERCLA } \\
\text { FFA status }\end{array}$ & SWMU note & $\begin{array}{l}\text { SWMU HSWA } \\
\text { permit } \\
\text { appendix } \\
\text { classification }^{a}\end{array}$ \\
\hline 501 & $\begin{array}{l}\text { C-14 } \\
\text { Maintenance-Res } \\
\text { piration Study }\end{array}$ & $\begin{array}{l}\text { Distance of } 1.7 \\
\text { miles an azimuth } \\
\text { of } \mathrm{N} 22 \text { from the } \\
\text { intersection of } \\
\text { Bear Creek and } \\
\text { Gum Branch } \\
\text { Reds. }\end{array}$ & $\begin{array}{l}\text { Thirty-six trees were contaminated with C-14 to study the } \\
\text { movement of carbon during the respiration. The isotope was } \\
\text { introduced as carbon dioxide. (Boston 1995) }\end{array}$ & $\begin{array}{l}\text { NFI } \\
\text { approved } \\
4 / 96\end{array}$ & & \\
\hline 505 & $\begin{array}{l}\text { Ca- } 45 \text { Tagged } \\
\text { Trees }\end{array}$ & $\begin{array}{l}\text { Distance of } 2 \\
\text { miles on an } \\
\text { azimuth of N } 24 \mathrm{E} \\
\text { from the } \\
\text { intersection of } \\
\text { Bethel and Melton } \\
\text { Valley Reds. }\end{array}$ & $\begin{array}{l}\text { Several red maple trees were inoculated with Ca- } 45 \text {, which was } \\
\text { allowed to move in the transpiration stream throughout the tree. } \\
\text { Objective was to produce Ca- } 45 \text { containing leaves for use in } \\
\text { experiments at ER-2. (Taylor 1986) }\end{array}$ & $\begin{array}{l}\text { NFI } \\
\text { approved } \\
10 / 94\end{array}$ & & \\
\hline 529 & $\begin{array}{l}\text { Cs- } 134 \\
\text { Contaminated } \\
\text { Oak Trees }\end{array}$ & $\begin{array}{l}\text { Two sites are on } \\
\text { the north slope of } \\
\text { Chestnut Ridge; } \\
\text { two sites are in } \\
\text { Melton Valley }\end{array}$ & $\begin{array}{l}\text { The study was conducted on } 12 \text { White Oak trees at } 4 \text { sites on } \\
\text { contrasting soil types and moisture conditions. Throughout the } \\
\text { growing season leaves were collected and analyzed for } \\
\text { radionuclide distribution. (Taylor 1986) }\end{array}$ & $\begin{array}{l}\text { NFI } \\
\text { approved } \\
2 / 98\end{array}$ & & \\
\hline 540 & $\begin{array}{l}\text { Cs-137, Fe-59 } \\
\text { Contaminated } \\
\text { Animal Pens } \\
\text { (McNew Hollow) }\end{array}$ & $\begin{array}{l}\text { Located } 2.1 \text { miles } \\
\text { on an azimuth of } \\
\mathrm{N} 18 \mathrm{~W} \text { from } \\
\text { intersection of } \mathrm{H} \\
95 \text { and Bethel } \\
\text { Valley Rd }\end{array}$ & $\begin{array}{l}\text { This field study was conducted to determine the elimination of } \\
{ }^{137} \mathrm{Cs} \text { and }{ }^{59} \mathrm{Fe} \text { by wild small rodents. Periodically, the animals } \\
\text { were live-trapped and taken to the laboratory for radiological } \\
\text { analysis. (Taylor 1986) }\end{array}$ & $\begin{array}{l}\text { NFI } \\
\text { approved } \\
2 / 98\end{array}$ & & \\
\hline 897 & $\begin{array}{l}\text { White Wing } \\
\text { Scrap Yard } \\
\text { (XDO751) }\end{array}$ & $\begin{array}{l}\text { McNew Hollow } \\
\text { area on W edge of } \\
\text { East Fork Ridge; } \\
1 \mathrm{mi} \text { E of White } \\
\text { Wing Rd/ Oak }\end{array}$ & $\begin{array}{l}\text { This facility was used for burial and aboveground storage of } \\
\text { contaminated materials from the four Oak Ridge Manhattan } \\
\text { Project plants. Hot Yard Road divides the area into north and } \\
\text { south components, the northern used by the Oak Ridge K- } 25 \text { Site } \\
\text { and the Oak Ridge Y-12 Plant and the southern by ORNL. }\end{array}$ & $\begin{array}{l}\text { Interim } \\
\text { remedial } \\
\text { action } \\
\text { complete. } \\
\text { Post-constr }\end{array}$ & $\begin{array}{l}\text { Buried scrap } \\
\text { metal; } \\
\text { CERCLA ROD } \\
\text { 10/92; interim } \\
\text { remedial action }\end{array}$ & A-1(a) \\
\hline
\end{tabular}


Bear Creek Burial Grounds

$3.2 \mathrm{~km}(2$ miles $)$ west of the Y-12 Plant, north of Bear Creek Road
Unit location

Ridge Tnpk

junction.
Portions of the yard were also used for disposal of equipment

from the wartime S-50 Liquid Thermal Diffusion Plant near K-25. No description exists for the materials stored by ORGDP and Y-12. The material stored by ORNL (estimated to be $500,00 \mathrm{ft}^{3}$ ) was reported to consist of $10 \times 40$ - $\mathrm{ft}$ mild steel tanks, dump trucks, two pieces of earth-moving equipment (one weighing 22 tons), large glass-lined tanks, walk-in hoods, support frames, steel and stainless steel, and aluminum of many sizes and shapes. During active use, the north part was enclosed by a chain link fence and the south portion with barbed wire fence. The yard stopped receiving wastes in 1964. In 1966, efforts were begun to clean up the area, and these fences were removed. Contaminated scrap materials were removed and buried in SWSA 5, and the uncontaminated material was sold to a contractor for scrap recovery. Site cleanup continued until March 1970, and in October 1970, removal of about $6000 \mathrm{yd}^{3}$ of contaminated soil from the southern portion of the site was initiated, however, some scrap metal, concrete, and other waste remains at the site. (Ford et al. 1992) In 1989, an extensive survey of the area was done both inside and outside the existing scrap-yard fence. This survey resulted in addition fencing being added in 1992 to encompass this contamination. Cleanups were later performed of aboveground debris. Hot spots have subsequently been found outside the newer fenced area, especially in the ditch running across the road west of the main fenced area.

The BCBG were used from about 1955 to 1991 to dispose of industrial wastes that were composed of or contaminated with uranium. During the early years of Y-12 Plant operation, the

Maintenance Division was responsible for waste disposal,

including waste disposals at the BCBG. Waste materials disposed

of in the BCBG came not only from the Y-12 Plant but also from Oak Ridge National Laboratory, K-25 Site, and facilities outside
SWMU HSWA

permit

appendix

CERCLA

FFA status

SWMU note

classification $^{a}$

\section{uction}

report

in 1994 for

approved

9/14/94.

surface debris.

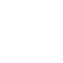


SWMU HSWA

permit

appendix

\begin{tabular}{c}
$\begin{array}{c}\text { Unit ID } \\
\text { number }\end{array}$ Unit title $\quad \begin{array}{c}\text { Unit location } \\
\text { description }\end{array}$ \\
\hline
\end{tabular}

CERCLA

FFA status

SWMU note

Oak Ridge. Materials delivered to the BCBG were segregated and Ground

disposed of in particular areas. Initially, there were only two

ROD.

areas: Burial Ground 1 and Burial Ground 2 (BG-1 and BG-2).

These areas were later subdivided, with BG-1 becoming Burial

Ground A (BG-A) and BG-2 being divided into multiple areas:

BG-B, -C, -D, -E, and -J. Trenches were dug in each area as

needed, with each trench receiving its own identification number.

For example, the number BG-A3E referred to the east end of

trench \#3 in the A area. Several areas were set aside for particular

materials: carbon foam (BG-A8FOAM), aerosol cans (BG-

A11AERCAN), asbestos (BG-A12ASBP), crucible oxides

(BG-BCRUCOX and BG-CCRUCOX), depleted uranium alloys

(BG-BDEPUCPD), depleted uranium (BG-BD38 and BG-CD38), and thorium (BG-BTHOR). The BCBGs consist of: Several principal waste disposal units designated as BG-A, -B, -C, -D, -E, and -J; Walk-In Pits (WIP); Uranium Vaults (Fig. A.8); and

ORP-1 and -2. Each waste disposal unit consisted of a series of trenches, 4.2 to $7.5 \mathrm{~m}$ (14 to $25 \mathrm{ft}$ ) deep, which were used for disposal of solid and liquid wastes. Waste disposals included: uranium-contaminated waste material, large pieces of uranium metal (machined parts), uranium tailings and chips generated by milling the machined parts, and uranium saw fines generated by fabrication methods. In general, the contaminated material and tailings were placed in the A trenches, and the large uranium parts/pieces were placed in $\mathrm{E}$ and $\mathrm{J}$ trenches. Some of the tailings were also placed in 1-B trenches, as well as in the $\mathrm{C}$ to $\mathrm{J}$ trenches. Unpublished reports and photographs indicate that, after disposal, uranium tailings exposed to air often oxidized rapidly, causing uranium fires. The most pyrophoric form of uranium disposed of in the BCBG, saw fines and chips, was disposed of in the WIP in a manner that prevented rapid oxidation and subsequent fires. In addition, photographs also reveal that wastes in many trenches were submerged. Mercury, which is a known potential 


\section{Table B.1 (continued)}

SWMU HSWA

permit

Unit ID Unit location

number Unit title description

CERCLA

appendix description

contaminant throughout the $\mathrm{Y}-12$ complex, is also found in the

BCBG. Because actual quantities of mercury disposed of at Y-12 were not routinely recorded. Before 1968, oils (including those contaminated with PCBs) were burned for disposal in the BCBG. PCBs were also used in the plant in transformers and as a coolant component for the $\mathrm{M}-\mathrm{Wing}$ and the Z-oil system. These original coolants, as well as subsequent non-PCB coolant change-out fluids, were deposited in the BCBG. Waste oils and coolants, which contained varying amounts of organic compounds

(potentially with PCB content), were used to bathe uranium chips before disposal. Actual quantities and identities of materials deposited in the BCBG have a high degree of uncertainty. Small amounts of unrecorded material may also have been buried in these areas. Area A Area A-South was the initial disposal site within the BCBG and was operational for about 6 years before other areas were opened. Uranium is a major contaminant in every BCBG area. Area A was targeted primarily for waste types identified as containing depleted uranium contamination. A wide variety of contaminated debris and wastes were deposited in Area $\mathrm{A}$, and small amounts of waste contaminated with enriched uranium may also have been disposed of here. Areas A-16 through A-18 are relatively recent burial sites designated strictly for uranium-contaminated trash; they are assumed to contain no other waste types. Other radioactive materials

1118 Building $9818 \quad$ Building 9818 \{Recycling Unit\} 


\begin{tabular}{|c|c|c|c|}
\hline $\begin{array}{l}\text { Unit ID } \\
\text { number }\end{array}$ & Unit title & $\begin{array}{l}\text { Unit location } \\
\text { description }\end{array}$ & History \\
\hline 1151 & $\begin{array}{l}\text { Contaminated } \\
\text { Construction } \\
\text { Spoil Pile }\end{array}$ & $\begin{array}{l}\text { Between Bear } \\
\text { Creek and NT-2, } \\
\text { immediately north } \\
\text { of MK-F } \\
\text { Laydown Area at } \\
\text { Y-12 }\end{array}$ & $\begin{array}{l}\text { This unit consists of soil excavated during construction of the } \\
\text { first tank farm for the West End Treatment Facility. }\end{array}$ \\
\hline 1155 & $\begin{array}{l}\text { DARA Liquid } \\
\text { Storage And } \\
\text { Treatment } \\
\text { Facility }\end{array}$ & $\begin{array}{l}\text { Adjacent to } \\
\text { Bldg. } 9720-60 \text {; } \\
\text { west of Y-12, } \\
\text { north of Bear } \\
\text { Creek Road }\end{array}$ & \\
\hline 1156 & $\begin{array}{l}\text { DARA Solids } \\
\text { Storage Facility }\end{array}$ & $\begin{array}{l}\text { In Bear Creek } \\
\text { Burial Ground } \\
\text { approx. } 2 \text { miles } \\
\text { west of Y-12 }\end{array}$ & $\begin{array}{l}\text { Building 9720-60 is designed to dewater soils by gravity flow to } \\
\text { sumps. The Building encloses a concrete basin designed to } \\
\text { dewater soils by gravity flow to sumps. Collected liquids are } \\
\text { pumped to the DARA LSF. Soil and liquids were products of the } \\
\text { excavation and closure of the oil retention ponds and associated } \\
\text { tributaries. The site has leak detection monitoring. }\end{array}$ \\
\hline
\end{tabular}

SWMU HSWA

permit

appendix

CERCLA

FFA status

SWMU note

classification $^{a}$

BCV Phase EPA declared

1 ROD

soils not solid

Historical

determined wastes

that this OU

is not

significant

contributor

watershed

contaminati

on and it

was to be

remediated

as routine

maintenance

action

CWA

Permit-by-rule;

also PCB

storage (TS-24)

RCRA Interim

Status waste

pile; also PCB

storage (TS-13)
A-2

A-1(a)

excavation and closure of the oil retention ponds and associated 


\begin{tabular}{|c|c|c|c|c|c|c|}
\hline $\begin{array}{l}\text { Unit ID } \\
\text { number }\end{array}$ & Unit title & $\begin{array}{l}\text { Unit location } \\
\text { description }\end{array}$ & History & $\begin{array}{c}\text { CERCLA } \\
\text { FFA status }\end{array}$ & SWMU note & $\begin{array}{l}\text { SWMU HSWA } \\
\text { permit } \\
\text { appendix } \\
\text { classification }^{a}\end{array}$ \\
\hline 1157 & $\begin{array}{l}\text { Decant Treatment } \\
\text { Facility }\{S-3 \\
\text { Liquid Treatment } \\
\text { Facility }\}\end{array}$ & $\begin{array}{l}\text { North of the S-3 } \\
\text { Pond Parking Lot }\end{array}$ & $\begin{array}{l}\text { This facility consists of an open Building with three settling } \\
\text { basins and was used for treatment of denitrified supernatant from } \\
\text { S3 ponds and West End Treatment Facility tanks. This unit has } \\
\text { full secondary containment, which has not been breached. }\end{array}$ & $\begin{array}{l}\text { No Further } \\
\text { Action }\end{array}$ & $\begin{array}{l}\text { CWA } \\
\text { Permit-by-rule }\end{array}$ & A-2 \\
\hline 1183 & $\begin{array}{l}\text { Groundwater } \\
\text { Treatment } \\
\text { Facility (GWTF) }\end{array}$ & $\begin{array}{l}\text { West end of Y-12 } \\
\text { Plant, west of S-3 } \\
\text { parking lot }\end{array}$ & & & $\begin{array}{l}\text { CWA } \\
\text { wastewater } \\
\text { treatment; } \\
\text { includes } \\
\text { permit-by-rule } \\
\text { tanks }\end{array}$ & A-2 \\
\hline 1184 & $\begin{array}{l}\text { Hazardous } \\
\text { Chemical Area } \\
\{\text { Burnyard-Boney } \\
\text { ard }\}\end{array}$ & $\begin{array}{l}\text { Bear Creek } \\
\text { Valley, is part of } \\
\text { an area referred to } \\
\text { as } \\
\text { Burnyard/Boneyar } \\
\text { d (BY/BY). }\end{array}$ & $\begin{array}{l}\text { Generally, the HCDA received wastes from two sources that } \\
\text { posed safety hazards within the Y-12 Plant: (1) gas cylinders with } \\
\text { leaking or damaged valves and (2) laboratory chemicals } \\
\text { considered to be reactive or explosive. Gas cylinders containing } \\
\text { noncorrosive gases were allowed to leak into the atmosphere or } \\
\text { were bled off to expedite the process. Those containing corrosive } \\
\text { gases were bled through neutralizing slurries. Empty gas } \\
\text { cylinders were either destroyed or transported to another location } \\
\text { for repair. The lab chemicals included acids, bases, organics, } \\
\text { water-reactive compounds, and explosive compounds such as } \\
\text { picric acid, benzyl peroxide, and ether. Bottles of chemicals were } \\
\text { broken under water spray in a concrete vessel that was open to } \\
\text { the atmosphere. After the explosion or chemical reaction had } \\
\text { taken place, the effluent was discharged into a small-unlined } \\
\text { surface impoundment and allowed to percolate through the soil. } \\
\text { The chemical residue remaining in the concrete vessel was } \\
\text { removed periodically and transported to the BCBG. In 1989, the } \\
\text { HCDA was covered with a cap of RCRA multilayer type } \\
\text { construction; however, no actions to remediate soils were } \\
\text { conducted before capping. This cap is not included in the BCV } \\
\text { postclosure permit. }\end{array}$ & $\begin{array}{l}\text { RDR/RAW } \\
\text { P approved } \\
9 / 15 / 00\end{array}$ & $\begin{array}{l}\text { RCRA-like } \\
\text { closure in } 11 / 90\end{array}$ & A-1(a) \\
\hline
\end{tabular}


post-excavation sampling was conducted to confirm that the

$<25$ ppm standard had been attained. Before December 1984, groundwater monitoring at the OLF was conducted in accordance with two DOE groundwater-monitoring programs. Historical monitoring at the site was conducted from 1975 to 1987 as part of a program to identify groundwater contamination sources at the

Y-12 Plant. Characterization monitoring began in 1983 in response to the MOU signed by DOE, EPA, and TDEC and continued until 1986. Groundwater quality data collected during historical and characterization monitoring verified the presence of contaminants in groundwater at the OLF. Therefore, interim status assessment monitoring was implemented at the site in lieu of detection monitoring, as required under TN Rule

1200-1-11-.05(6)(a)4. Assessment monitoring was initiated at the OLF in January 1986.

1205 Oil Landfarm At the Y-12 Oil Soils

Landfarm site in Containment Pad Bear Creek Valley
The site is used as a storage facility for contaminated soils from the closure of the Oil Landfarm.
RAR approved $7 / 16 / 01$
RCRA Interim

Status waste

pile; also PCB

storage (TS-12).

RCRA clean

closed on

11/22/00.

Closure part

Bear Creek

Valley

CERCLA

remedial action

and waste

disposed

off-site. 
Disposal Area Remedial Action (DARA) facility located to the west of ORP-1. A total of 980 screening samples (rapid turnaround) were taken during excavation to guide removal activities. A total of 287 certification samples of remaining soils were taken, and all but one of the contaminated areas in ORP-1, ORP-2, and NT- 7 were certified to have $<25$ ppm PCBs. In one area, the seepage area (Seep 1) to the west of BG- A North, higher than anticipated concentrations of PCBs were encountered during excavation (1,200 ppm). This area was closed without achieving the 25-ppm acceptance criteria. The ponds and the section of NT-7 north of ORP-1 were then covered with an engineered multilayered cap. The portion of NT-7 below ORP-1 was capped with a clay cap at this time. A new channel was constructed for NT-7, and this tributary was rerouted $15 \mathrm{~m}(50 \mathrm{ft})$ to the west of its original course.

\section{Oil Retention} Pond No. 2
On Tributary

NT-6 at the northeast corner of Bear Creek Burial Ground A
ORP-1 and -2 were constructed to prevent downstream transport of oil in NT-6 and NT-7. Although overflow of mop water from standpipes had occurred previously, oil was first observed seeping from the west ends of trenches in BG-A into NT-7 and from the soil surface above the oil disposal pits between 1969 an 1971. At this time, oil disposal in the BG-A South trenches was discontinued. ORP-2 was located northeast of BCBG A North. No significant oil accumulation was reported on the surface of ORP-2 from 1975 to closure of the pond in 1989. Both ORPs were closed and capped under an approved RCRA closure plan in 1989. During closure operations, $3060 \mathrm{~m} 3\left(4,000 \mathrm{yd}^{3}\right)$ of sludge, sediment, and soil were excavated from ORP-1, ORP-2, and NT-7. This waste was placed in the Disposal Area Remedial Action (DARA) facility located to the west of ORP-1. A total of 980 screening samples (rapid turnaround) were taken during excavation to guide removal activities. A total of 287 certification samples of remaining soils were taken, and all but one of the
PP approved; closure 12/90; deferred to groundwater a future cont. deferred to CERCLA
A-1(a) 
SWMU HSWA

permit

appendix
classification

\begin{tabular}{cc} 
Unit ID & $\begin{array}{c}\text { Unit location } \\
\text { description }\end{array}$ \\
\hline
\end{tabular}

CERCLA

contaminated areas in ORP-1, ORP-2, and NT- 7 were certified to have $<25 \mathrm{ppm}$ PCBs. In one area, the seepage area (Seep 1) to the west of BG- A North, higher than anticipated concentrations of PCBs were encountered during excavation $(1,200 \mathrm{ppm})$. This area was closed without achieving the 25 -ppm acceptance criteria. The ponds and the section of NT-7 north of ORP-1 were then covered with an engineered multilayered cap.

1222 Maynardville TCE

Groundwater

Plume
Bear Creek

Valley, just west

of Y-12 Plant

main facilities

\section{Bear Creek}

Valley, just west

of Y-12 Plant on

Old Bear Creek

Road
SY-200 Yard was operated as an aboveground "hold for future use" storage area. The site was surrounded by a 6-ft fence with gate access. During operation, there were no underground utilities or piping at the site. Y-12 Plant operations divisions that used the yard included the Assembly, Engineering and Technology, Metal Preparation, and ORNL Fusion Energy. Items stored at the site were segregated with respect to ownership by the various operating divisions using the yards. Fill soil was placed in the area in the 1950s, and there are no records of the sources of this fill. All items stored at the site were removed by September 1986 to prepare the area as the future site for an Environmental Support Facility (ESF) to include a maintenance shop, office complex, tanker terminal, and security portal. Before removal, all items were surveyed by Y-12 Health Physics Department and flagged for proper disposal and handling. The yard remained unused until ESF construction activities were initiated in

December 1988. At that time, the fence surrounding the SY-200 yard was removed, and a larger one encompassing all proposed ESF operations was erected. During construction of the ESF

\section{RI}

approved;

deferred to

a future

decision.

NFA.

Former

salvage/waste

SandM and area; CERCLA

monitoring ROD approved

ongoing. $1 / 23 / 97$. 
building, the top 6 in of gravel and soil were removed and stored in the southwest corner of the site. Excavation for the

Building foundation progressed until $\sim 8 \mathrm{ft}$ of fill material was removed and bermed along the north and east corners of the excavation. Because no natural soils were encountered during the excavation, construction activities ceased for evaluation of engineering designs. Construction activities resumed in September 1989, when the top 6 inches of soil that had been removed in December 1988 was spread and graded over the bottom of the excavation. A silt fence was placed along Bear Creek to intercept runoff and eroded sills. In light of the RFI process, construction of the ESF on the SY-200 Yard site has ceased. In early 1990, the material bermed along the north and east corners of the ESF excavation were placed back in the excavated area and covered with about $5 \mathrm{ft}$ of clean borrow material. The ESF is currently under construction immediately south of Old Bear Creek Road.

1229 Sanitary Landfill
Spoil Area I (Landfill)
0.8 mile west of the Y-12 Plant, just north of Bear Creek and immediately south of the OLF.

Bear Creek Valley, just west of Y-12 Plant main facilities
SL 1 was used between 1968 and 1983 for the disposal of combustible and decomposable solid wastes. The trench at SL was excavated to a depth of approximately $20 \mathrm{ft}$ and backfilled to approximately $15 \mathrm{ft}$ above grade. SL 1 was closed in 1985 by

grading the site to promote drainage, capping it with $2 \mathrm{ft}$ ) of clay and topsoil, and establishing a vegetation cover.

Various renovation, maintenance, and construction operations at Y-12 produced construction debris that were disposed of in this facility. The facility stopped receiving spoils in 1985 , and a clay cover was placed over the area. $\begin{array}{ll}\text { NFA. } & \begin{array}{l}\text { Solid waste } \\ \text { closure under }\end{array} \\ & \text { TDEC; Subtitle }\end{array}$

NFA

approved

7/26/96.

Annual

S\&M and

monitoring

ongoing
CERCLA ROD 
Table B.1 (continued)

SWMU HSWA

permit

appendix

\begin{tabular}{|c|c|c|c|c|c|c|}
\hline $\begin{array}{l}\text { Unit ID } \\
\text { number }\end{array}$ & Unit title & $\begin{array}{l}\text { Unit location } \\
\text { description }\end{array}$ & History & $\begin{array}{l}\text { CERCLA } \\
\text { FFA status }\end{array}$ & SWMU note & $\begin{array}{c}\text { appendix } \\
\text { classification }^{a}\end{array}$ \\
\hline 1303 & $\begin{array}{l}\text { West End } \\
\text { Treatment } \\
\text { Facility }\end{array}$ & $\begin{array}{l}\text { West of S-3 } \\
\text { Parking Lob and } \\
\text { South of Bear }\end{array}$ & & & $\begin{array}{l}\text { CWA } \\
\text { wastewater } \\
\text { treatment }\end{array}$ & A-2 \\
\hline
\end{tabular}

PP

Creekside Debris Between Bear Unknown

Burial Creek and Bear

Creek Road, north

of Rust Spoil Area

approved;

deferred to

a future

decision.

Proposed

for a $\mathrm{BCV}$

Valley

Floodplain

Early

Action that

was

cancelled

with

regulatory

agreement

in 1998.

Decision

will be

captured in

the BCV

Burial

Ground

ROD. 
Table B.1 (continued)

\begin{tabular}{|c|c|c|c|c|c|c|}
\hline $\begin{array}{l}\text { Unit ID } \\
\text { number }\end{array}$ & Unit title & $\begin{array}{c}\begin{array}{c}\text { Unit location } \\
\text { description }\end{array} \\
\end{array}$ & History & $\begin{array}{c}\text { CERCLA } \\
\text { FFA status } \\
\end{array}$ & SWMU note & $\begin{array}{l}\text { SWMU HSWA } \\
\text { permit } \\
\text { appendix } \\
\text { classification }^{a}\end{array}$ \\
\hline 1333 & $\begin{array}{l}\text { Bear Creek Road } \\
\text { Debris Burial } \\
\text { (a.k.a Roadside } \\
\text { Debris Area) }\end{array}$ & $\begin{array}{l}\text { South of Bear } \\
\text { Creek and Bear } \\
\text { Creek Road, west } \\
\text { of Rust Spoil Area } \\
\text { at Y-12 }\end{array}$ & Unknown. & $\begin{array}{l}\text { Proposed } \\
\text { for BCV } \\
\text { Floodplain } \\
\text { Hotspot } \\
\text { Removal } \\
\text { Early } \\
\text { Action, } \\
\text { project that } \\
\text { was } \\
\text { cancelled } \\
\text { with } \\
\text { regulatory } \\
\text { agreement } \\
\text { in 1998. } \\
\text { Will be } \\
\text { addressed } \\
\text { under BCV } \\
\text { Burial } \\
\text { Ground } \\
\text { ROD }\end{array}$ & & \\
\hline 1481 & $\begin{array}{l}\text { Pine Ridge Study } \\
\text { Area (\#4b) }\end{array}$ & $\begin{array}{l}\text { Northwest Pine } \\
\text { Ridge, bounded } \\
\text { by Gum Branch } \\
\text { Road, Midway } \\
\text { Turnpike, and the } \\
\text { crest of Pine } \\
\text { Ridge }\end{array}$ & $\begin{array}{l}\text { The remains of one pre-WWII structure remains on the site. The } \\
\text { area has been used for environmental study, although only one, } \\
\text { C-14 Maintenance-Respiration Study, involved radiological or } \\
\text { hazardous constituents. This study area, described elsewhere, has } \\
\text { received NFI approval. }\end{array}$ & $\begin{array}{l}1,051 \text { acres; } \\
\text { NFI } \\
\text { approved } \\
6 / 97\end{array}$ & & \\
\hline
\end{tabular}




\begin{tabular}{|c|c|c|c|c|c|c|}
\hline $\begin{array}{l}\text { Unit ID } \\
\text { number }\end{array}$ & Unit title & $\begin{array}{c}\begin{array}{c}\text { Unit location } \\
\text { description }\end{array} \\
\end{array}$ & History & $\begin{array}{c}\text { CERCLA } \\
\text { FFA status } \\
\end{array}$ & SWMU note & $\begin{array}{c}\text { SWMU HSWA } \\
\text { permit } \\
\text { appendix } \\
\text { classification }^{a}\end{array}$ \\
\hline 1484 & $\begin{array}{l}\text { East Fork } \\
\text { Ridge/White } \\
\text { Wing Study Area } \\
(\# 4 a)\end{array}$ & $\begin{array}{l}\text { ORR, bounded by } \\
\text { SR-95, Oak Ridge } \\
\text { Turnpike, Bear } \\
\text { Creek Road, } \\
\text { Midway } \\
\text { Turnpike, and } \\
\text { Gum Branch } \\
\text { Road }\end{array}$ & $\begin{array}{l}\text { The remains of several pre-WWII agricultural/residential } \\
\text { structures are located in this site. One radiological research area, } \\
\text { Cs-137, Fe-59 Contaminated Animal Pens, is located in this area } \\
\text { and has been excluded from the study area pending approval of a } \\
\text { NFI determination. White Wing Scrap Yard (WAG 11) is located } \\
\text { within this study area, but has been excluded from the study area } \\
\text { boundaries. }\end{array}$ & $\begin{array}{l}1,818 \text { acres; } \\
\text { NFI } \\
\text { approved } \\
3 / 98\end{array}$ & & \\
\hline 1543 & $\begin{array}{l}\text { Bear Creek } \\
\text { Floodplain }\end{array}$ & $\begin{array}{l}\text { The area is located } \\
\text { south of the White } \\
\text { Wing Scrapyard } \\
\text { west of SR-95 and } \\
\text { south of the Oak } \\
\text { Ridge Turnpike }\end{array}$ & $\begin{array}{l}\text { According to the BCV RI there is no evidence that this site has } \\
\text { contributed to environmental contamination or poses a risk to the } \\
\text { environment or humans. This area was addressed in a footprint } \\
\text { reduction evaluation of the West Pine Ridge Study area to } \\
\text { evaluate potential contamination from the White Wing Scrap } \\
\text { Yard. }\end{array}$ & & & \\
\hline 1554 & $\begin{array}{l}\text { White Wing } \\
\text { Scrap Yard East } \\
\text { Creek }\end{array}$ & Not Available & & & & \\
\hline 1555 & $\begin{array}{l}\text { White Wing } \\
\text { Scrap Yard West } \\
\text { Creek }\end{array}$ & Not Available & & & & \\
\hline 1558 & $\begin{array}{l}\text { East Fork Ridge } \\
\text { Knob }\end{array}$ & Not Available & & & & \\
\hline 2317 & $\begin{array}{l}\text { Bear Creek } \\
\text { Contaminated } \\
\text { Floodplain Soils }\end{array}$ & & & & & \\
\hline
\end{tabular}




\begin{tabular}{|c|c|c|c|c|c|c|}
\hline $\begin{array}{l}\text { Unit ID } \\
\text { number }\end{array}$ & Unit title & $\begin{array}{c}\text { Unit location } \\
\text { description }\end{array}$ & History & $\begin{array}{c}\text { CERCLA } \\
\text { FFA status }\end{array}$ & SWMU note & $\begin{array}{l}\text { SWMU HSWA } \\
\text { permit } \\
\text { appendix } \\
\text { classification }^{a}\end{array}$ \\
\hline 2319 & $\begin{array}{l}\text { S-3 Ponds } \\
\text { (Western Plume) } \\
\text { Pathways } 1 \text { and } 2\end{array}$ & $\begin{array}{l}\text { The S-3 Ponds are } \\
\text { located in the } \\
\text { western end of the } \\
\text { Y-12 NSC. A } \\
\text { portion of the } \\
\text { groundwater } \\
\text { contamination } \\
\text { from the ponds } \\
\text { extends into Bear } \\
\text { Creek Valley. }\end{array}$ & $\begin{array}{l}\text { The former S-3 Ponds Waste Management Area (S-3 Ponds), } \\
\text { now closed and capped, were used for disposal of acidic mixed } \\
\text { waste. }\end{array}$ & $\begin{array}{l}\text { Previous } \\
\text { action } \\
\text { memorandu } \\
\text { m approved } \\
\text { in BCV } \\
\text { Valley } \\
\text { ROD }\end{array}$ & & \\
\hline 2329 & $\begin{array}{l}\text { Rust Spoil Area } \\
\{\text { Landfill }\}\end{array}$ & TBD & $\begin{array}{l}\text { This unit was operated as a dump with periodic grading (typically } \\
\text { once a month) to promote positive drainage. Dumping progressed } \\
\text { northward from Old Bear Creek Road. As dumping occurred, the } \\
\text { natural topography was elevated, and a portion of the Bear Creek } \\
\text { channel was filled. Eventually, the stream channel course was } \\
\text { relocated to the north to compensate for outslope progression. } \\
\text { Routine compaction of soil was not intended but occurred only as } \\
\text { grading took place. Site closure activities began in fall } 1983 \text {. } \\
\text { These closure activities involved grading and shaping existing } \\
\text { fill, capping the entire fill area with a minimum of } 2 \mathrm{ft} \text { of soil, and } \\
\text { establishing vegetative growth over all disturbed areas. } \\
\text { Specifications called for a minimum of } 1.5 \mathrm{ft} \text { of compacted clay } \\
\text { and } 6 \text { inches of topsoil to be placed over the site. Closure was } \\
\text { completed in mid- } 1984 \text {. }\end{array}$ & $\begin{array}{l}\text { PP } \\
\text { approved; } \\
\text { deferred to } \\
\text { a future } \\
\text { decision. }\end{array}$ & $\begin{array}{l}\text { Includes capped } \\
\text { area and } \\
\text { equipment } \\
\text { storage }\end{array}$ & A-1(a) \\
\hline
\end{tabular}


Table B.1 (continued)

SWMU HSWA

permit

appendix

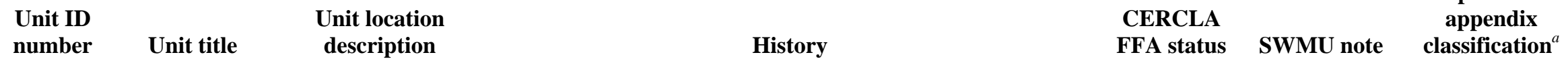

2440 S-3 Ponds The S-3 Ponds are The former S-3 Ponds Waste Management Area (S-3 Ponds),

(Western Plume) located in the now closed and capped, were used for disposal of acidic mixed

Remediatio

Pathway 3

waste.

western end of th

portion of the

groundwater

contamination

from the ponds

extends into Bear

Creek Valley.

2717 Clinch

TBD

River/Poplar

Creek

2789 White Wing

Scrap Yard

Groundwater

2790 Bear Creek

Valley

Groundwater

TBD

2791 Bear Creek

Valley Soils

RI

approved;

deferred to

a future

decision.

Includes

surface

water.

PP

approved;

deferred to

a future

decision. 
SWMU HSWA

permit

appendix

\begin{tabular}{|c|c|c|c|c|c|c|}
\hline $\begin{array}{l}\text { Unit ID } \\
\text { number }\end{array}$ & Unit title & $\begin{array}{l}\text { Unit location } \\
\text { description }\end{array}$ & History & $\begin{array}{l}\text { CERCLA } \\
\text { FFA status }\end{array}$ & SWMU note & $\begin{array}{c}\text { appendix } \\
\text { classification }^{a}\end{array}$ \\
\hline
\end{tabular}

\section{Chestnut Ridge Administrative Area}

19 Filled Coal Ash One-half mile The Coal Ash Pond was built in 1955 as a settling basin for coal Pond (McCoy south of the Y-12 ash from the Y-12 steam plant. The pond was created by Branch) Plant Building a 62-ft-high earthen dam across Upper McCoy Branch. Ash at the steam plant was mixed with untreated water from the Clinch River to form a slurry, then pumped to the crest of Chestnut Ridge and released through a large pipe. From the crest, the ash flowed by gravity down the slope of Chestnut Ridge into the pond. The pond was expected to have a 20-year capacity for ash. Ash filled the pond by 1967, however, and until 1989 the slurry was allowed to overtop the spillway and flow down Upper McCoy Branch to Rogers Quarry. Vegetation was allowed to grow on the dam, and over time the dam and spillway deteriorated. The CERCLA Record of Decision in 1996 identified stabilization of the pond dam as the preferred remedial alternative. The goal of this project was to prevent future release of coal ash slurry to the Upper McCoy Branch watershed by stabilizing the dam that supports the pond. The project achieved this goal by 1) raising the crest of the dam, 2) reinforcing the face of the dam, 3) installing a subsurface drain, 4) removing large trees from the face of the dam, and 5) repairing the emergency spillway. A small wetlands at the foot of the dam was restored and used as a passive treatment system for pollution abatement.

$\begin{array}{ll}\text { Remedial } & \text { Flyash disposal } \\ \text { action } & \text { area; CERCLA } \\ \text { complete } & \text { ROD }\end{array}$

action 
1144 Chestnut Ridge Borrow Area

Waste Pile

\section{Unit location description}

On Bethel Valley

Road,

approximately 3

mi west of Kerr

Hollow Quarry

McCoy Branch

drainage basin

below Filled Coal

Ash Pond and

above Roger's

Quarry

Located SW side

of Chestnut Ridge

and $\mathrm{N}$ of Bethel

Valley Rd. - 5

miles $\mathrm{E}$ of main

plant area

Chestnut Ridge near the east end of Y-12, just west of CR Sediment

Disposal Basin
The CRBAWP formerly provided clay for various projects. This unit received soils form the Oak Ridge Civic Center Sewer Line Beltway project. The landfill trench does indicate mercury contamination. The waste pile is underlain and covered with a 30-mil. polyethylene membrane.
The quarry was used as a source of construction materials from the 1940s through late 1950s. The quarry was abandoned in the early 960s and was subsequently used for disposal of a variety of materials from the Y-12 Plant. Until 1989 it received fly-ash slurry from the Y-12 Stem Plant

Drainage basin received flyash residues during operation of the Filled Coal Ash Pond.

The unit functioned as a land disposal operation for digested sewage sludge from the city of Oak Ridge's sewage treatment plant. (ORNL 1990)

$10 / 94$

Includes Civic

Flyash/solid A-1(a)

waste disposal area

SWMU HSWA

permit

appendix classification $^{a}$

\section{Center}

mercury-cont.

soil. Pile

removed in

2000 and

disposed of at

Y-12 Landfill

V. 


\begin{tabular}{|c|c|c|c|c|c|c|}
\hline $\begin{array}{l}\text { Unit ID } \\
\text { number }\end{array}$ & Unit title & $\begin{array}{c}\text { Unit location } \\
\text { description }\end{array}$ & History & $\begin{array}{c}\text { CERCLA } \\
\text { FFA status }\end{array}$ & SWMU note & $\begin{array}{c}\text { SWMU HSWA } \\
\text { permit } \\
\text { appendix } \\
\text { classification }^{a}\end{array}$ \\
\hline 1145 & $\begin{array}{l}\text { Chestnut Ridge } \\
\text { Mercury } \\
\text { Contaminated } \\
\text { Gully Soil Pile }\end{array}$ & $\begin{array}{l}\text { North of Patrol } \\
\text { Road and west of } \\
\text { 4th Street; } \\
\text { UEFPC } \\
\text { Subbasin J at } \\
\text { Y-12 }\end{array}$ & $\begin{array}{l}\text { This site is the location of a } 200 \text { - by } 350-\mathrm{ft}\left(70,000 \mathrm{ft}^{2}\right) \text { gully } \\
\text { where a } 70 \mathrm{ft} \text { long by } 30 \mathrm{ft} \text { wide }\left(300 \mathrm{yd}^{3}\right) \text { soil pile was disposed } \\
\text { of, covered with plastic, and overtopped. The gully was used for } \\
\text { storage of mercury-contaminated soil. Some of the soil was } \\
\text { excavated at the time the mercury was observed. The dates of } \\
\text { disposal are not given. Soil data indicate releases may have } \\
\text { occurred. }\end{array}$ & & $\begin{array}{l}\mathrm{Hg} . \\
\text { contaminated } \\
\text { soil disposal } \\
\text { area. }\end{array}$ & A-1(a) \\
\hline 1146 & $\begin{array}{l}\text { Chestnut Ridge } \\
\text { Security Pits }\end{array}$ & $\begin{array}{l}\text { Atop Chestnut } \\
\text { Ridge, } \\
\text { approximately } \\
800 \mathrm{ft} \text { southeast of } \\
\text { the central portion } \\
\text { of Y-12 Plant }\end{array}$ & 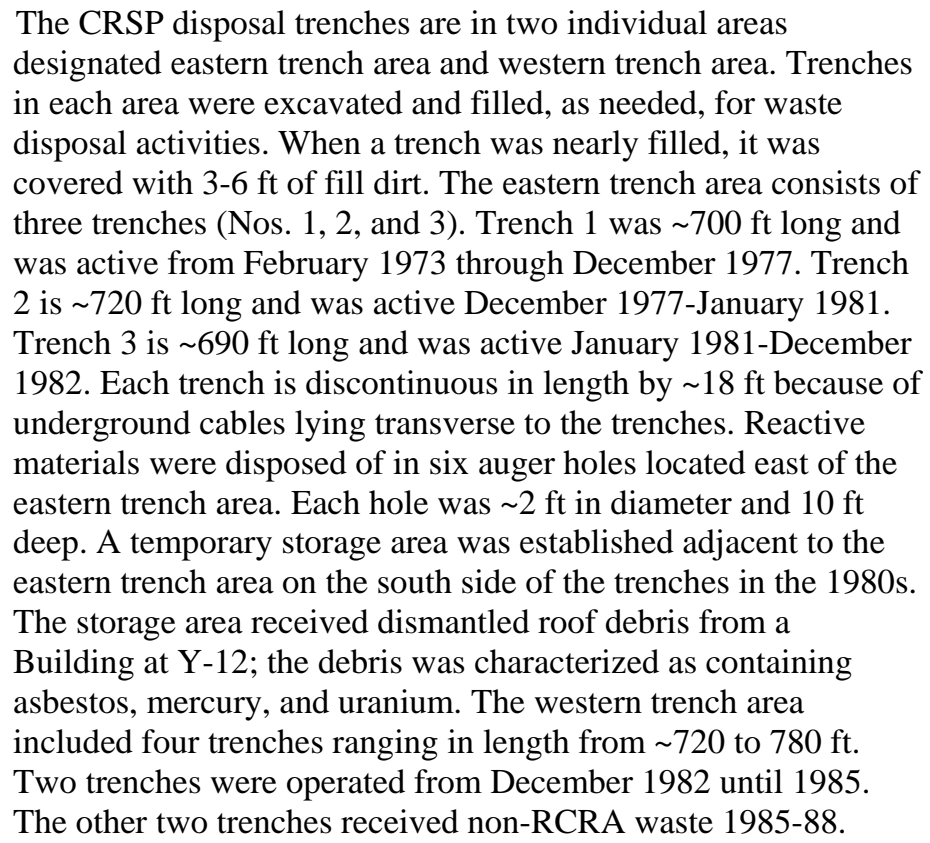 & $\begin{array}{l}\text { Postclosure } \\
\text { Permit } \\
\text { issued } 8 / 96 .\end{array}$ & $\begin{array}{l}\text { RCRA Closure } \\
12 / 89 ; \\
\text { postclosure } \\
\text { permit } 9 / 95\end{array}$ & A-1(a) \\
\hline
\end{tabular}




\begin{tabular}{|c|c|c|c|c|c|c|}
\hline $\begin{array}{l}\text { Unit ID } \\
\text { number }\end{array}$ & Unit title & $\begin{array}{l}\text { Unit location } \\
\text { description }\end{array}$ & History & $\begin{array}{c}\text { CERCLA } \\
\text { FFA status }\end{array}$ & SWMU note & $\begin{array}{l}\text { SWMU HSWA } \\
\text { permit } \\
\text { appendix } \\
\text { classification }^{a}\end{array}$ \\
\hline 1147 & $\begin{array}{l}\text { Chestnut Ridge } \\
\text { Sediment } \\
\text { Disposal Basin }\end{array}$ & $\begin{array}{l}\text { At a low pint on } \\
\text { the eastern crest } \\
\text { of Chestnut } \\
\text { Ridge, near New } \\
\text { Hope Pond }\end{array}$ & $\begin{array}{l}\text { This facility is an unlined, man-made surface impoundment built } \\
\text { in } 1972-73 \text { to dispose of sediments dredged from New Hope } \\
\text { Pond. The east and west walls are naturally topography with the } \\
\text { north and south walls being clay dikes. Sediment and soil were } \\
\text { added to the pond from a variety of sources beginning in } 1973 \text {. } \\
\text { The basin was closed as a landfill in 1988. A multi-layered, } \\
\text { engineered cap was installed. }\end{array}$ & $\begin{array}{l}\text { Postclosure } \\
\text { Permit } \\
\text { issued 9/95. }\end{array}$ & $\begin{array}{l}\text { RCRA Closure } \\
12 / 89 ; \\
\text { postclosure } \\
\text { permit } 9 / 95\end{array}$ & A-1(a) \\
\hline 1152 & $\begin{array}{l}\text { Containerized } \\
\text { Waste Storage } \\
\text { Area }\end{array}$ & $\begin{array}{l}\text { East Chestnut } \\
\text { Ridge, north side } \\
\text { of South Patrol } \\
\text { Road }\end{array}$ & & & $\begin{array}{l}\text { RCRA Permit } \\
\text { (TNHW 083). } \\
\text { RCRA clean } \\
\text { closure TDEC } \\
\text { certified } \\
\text { 3/16/00. } \\
\text { Currently used } \\
\text { for LLLW } \\
\text { storage. }\end{array}$ & A-2 \\
\hline 1180 & $\begin{array}{l}\text { East Chestnut } \\
\text { Ridge Waste Pile }\end{array}$ & $\begin{array}{l}\text { Eastern end of } \\
\text { Chestnut Ridge, } \\
\text { adjacent to East } \\
\text { Patrol Road, south } \\
\text { of Y-12 }\end{array}$ & $\begin{array}{l}\text { The waste pile is used for the temporary storage of soils and } \\
\text { spoils contaminated with hazardous and low-level radioactive } \\
\text { materials, asbestos and roofing material from the closure of other } \\
\text { RCRA sites at Y-12. The unit has a synthetic liner on the bottom } \\
\text { and sides to collect leachate, which is diverted to a sump. Wastes } \\
\text { were initially placed on the pile in August } 1987 \text {. The wastes were } \\
\text { mercury- and cadmium-contaminated soils excavated from the } \\
\text { Interim Drum Yard. From June } 1988 \text { through August } 1989 \text {, } \\
\text { additional mercury-contaminated waste consisting of roofing } \\
\text { material, sand, resin, insulation, clay pipe and concrete pipe were } \\
\text { placed on the pile. Some of the wastes also contained asbestos, } \\
\text { and some were contaminated with low-level radioactive } \\
\text { materials. The unit was temporarily covered with } 1-1.5 \mathrm{ft} \text { of clay } \\
\text { in August } 1989 \text {. Grass was planted on the cover to prevent } \\
\text { erosion. }\end{array}$ & $\begin{array}{l}\text { To be } \\
\text { remediated } \\
\text { under } \\
\text { RCRA and } \\
\text { addressed } \\
\text { in Chestnut } \\
\text { Ridge } \\
\text { ROD. }\end{array}$ & $\begin{array}{l}\text { RCRA Interim } \\
\text { Status }\end{array}$ & A-1(a) \\
\hline
\end{tabular}




\begin{tabular}{|c|c|c|}
\hline $\begin{array}{l}\text { Unit ID } \\
\text { number }\end{array}$ & Unit title & $\begin{array}{l}\text { Unit location } \\
\text { description }\end{array}$ \\
\hline 1192 & $\begin{array}{l}\text { Kerr Hollow } \\
\text { Quarry }\end{array}$ & $\begin{array}{l}\sim 1000 \mathrm{ft} \text { north of } \\
\text { Bethel Valley } \\
\text { Road, } 1.5 \text { mile } \\
\text { south of Y-12 }\end{array}$ \\
\hline
\end{tabular}
south of Y-12
SWMU HSWA

permit

appendix

CERCLA

FFA status SWMU note

classification $^{a}$

The quarry site was leased to the Ralph Rogers Company in the early 1940s by the Clinton Engineer Works to provide rock and gravel for CEW construction. By the late 1940s, the quality of stone had degraded; the quarry was abandoned and eventually filled with water. The quarry was subsequently used as a treatment site for water-reactive, corrosive, or ignitable wastes from Y-12 and X-10 from 1951 to 1988. The site received containers of waste in various sizes, consisting mainly of gas cylinders, drums, and buckets. Water-reactive materials such as lithium, potassium, sodium, or sodium-potassium alloy were normally packaged in 5-, 30- or 55-gal containers. They were then transported to the quarry, placed in a chute, and dropped to the water surface. Rifle fire punctured the containers, thus

allowing water to contact the reactive metal or alloy, which then reacted with the metal, releasing hydrogen gas and forming nonhazardous oxides and hydroxides with the alkaline metal. A complete reaction of the metal was assured due to the violent nature of the reactions; an explosion or violent burning was seen shortly after the container was punctured, and it sank below the surface of the water. A limited number of large pressure vessels containing sodium were placed in the quarry. Because the large containers were too heavy to float, they were dropped from the upper rim of the quarry and allowed to vent as they entered the water by positioning the valves and vent pipes in the "Open" position. Any potential explosive chemicals were suspended on a cord above the water surface and punctured with rifle fire before being dropped into the water. Cylinder breaching and removal began at the quarry on August 31, 1990. Metals were removed and shredded. Final waste removal and inspection was completed October 22, 1993. The last of the operating equipment was removed from the quarry on November 11, 1993.

\section{NFA RCRA closure}

approved

9/25/95.

Annual

2/95;

A-2

monitoring CERCLA NFA

ongoing. ROD 9/29/95 


\begin{tabular}{|c|c|c|c|c|c|c|}
\hline $\begin{array}{l}\text { Unit ID } \\
\text { number }\end{array}$ & Unit title & $\begin{array}{l}\text { Unit location } \\
\text { description }\end{array}$ & History & $\begin{array}{l}\text { CERCLA } \\
\text { FFA status }\end{array}$ & SWMU note & $\begin{array}{l}\text { SWMU HSWA } \\
\text { permit } \\
\text { appendix } \\
\text { classification }^{a}\end{array}$ \\
\hline 1195 & $\begin{array}{l}\text { Kerr Hollow } \\
\text { Quarry; AA-84 }\end{array}$ & TBD & & & $\begin{array}{l}\text { RCRA 90-day } \\
\text { accumulation } \\
\text { area; no } \\
\text { releases }\end{array}$ & Historical \\
\hline 1234 & $\begin{array}{l}\text { Storm Sewer } \\
\text { Sediment Drying } \\
\text { Facility }\end{array}$ & $\begin{array}{l}\text { Between } \\
\text { Bldg. } 9720-44 \text { and } \\
\text { South Patrol Road } \\
\text { at Y-12 }\end{array}$ & $\begin{array}{l}\text { This unit consists of sand beds, sumps, and storage pad. From } \\
1986 \text { to } 1992 \text {, the site accepted mercury-contaminated storm } \\
\text { sewer sediments (not EP toxic). Supernant was pumped to an } \\
\text { adjacent tank, and the sediments were sent to drying beds. Dried } \\
\text { sediments were containerized. Removed from Appendix C } 9 / 99 \\
\text { after determination that this is an active Waste Management } \\
\text { facility. }\end{array}$ & & $\begin{array}{l}\text { Sludge drying } \\
\text { beds/basin; } \\
\text { cont. sediments } \\
\text { containerized } \\
\text { and moved to } \\
\text { K-25 }\end{array}$ & A-2 \\
\hline 1246 & $\begin{array}{l}\text { Tank 2069-U } \\
\text { \{Bldg. 9213\} }\end{array}$ & $\begin{array}{l}\text { East of } \\
\text { Bldg. } 9213\end{array}$ & & & $\begin{array}{l}\text { Holding tank } \\
\text { for neutralized } \\
\text { wastewater }\end{array}$ & A-2 \\
\hline 1247 & $\begin{array}{l}\text { Tank 2070-U } \\
\text { \{Bldg. 9213\} }\end{array}$ & $\begin{array}{l}\text { East of } \\
\text { Bldg. } 9213\end{array}$ & & & $\begin{array}{l}\text { Holding tank } \\
\text { for neutralized } \\
\text { wastewater }\end{array}$ & A-2 \\
\hline 1248 & $\begin{array}{l}\text { Tank 2071-U } \\
\{\text { Bldg. 9213\} }\end{array}$ & $\begin{array}{l}\text { East of } \\
\text { Bldg. } 9213\end{array}$ & & & $\begin{array}{l}\text { Lab } \\
\text { wastewaters } \\
\text { neutralization } \\
\text { pit }\end{array}$ & A-2 \\
\hline 1230 & $\begin{array}{l}\text { Sanitary Landfill } \\
\text { II }\end{array}$ & $\begin{array}{l}\text { South side of } \\
\text { Y-12 Plant on } \\
\text { Chestnut Ridge }\end{array}$ & & & $\begin{array}{l}\text { TDEC approved } \\
\text { closure } 12 / 95 \text {. }\end{array}$ & A-2 \\
\hline 1291 & $\begin{array}{l}\text { Temporary } \\
\text { Storage Area }\end{array}$ & $\begin{array}{l}\text { On Chestnut } \\
\text { Ridge, north of } \\
\text { South Patrol Road }\end{array}$ & $\begin{array}{l}\text { This area was used for storage of mercury-and } \\
\text { uranium-contaminated roofing materials from } 1987 \text { until } \\
\text { Industrial Landfill III was completed, however materials remain. }\end{array}$ & $\begin{array}{l}\text { Will be } \\
\text { addressed } \\
\text { in Chestnut } \\
\text { Ridge ROD }\end{array}$ & $\begin{array}{l}\text { Contains buried } \\
\text { YS-122 roofing } \\
\text { waste }\end{array}$ & A-1(a) \\
\hline
\end{tabular}




\begin{tabular}{|c|c|c|c|}
\hline $\begin{array}{l}\text { Unit ID } \\
\text { number }\end{array}$ & Unit title & $\begin{array}{c}\begin{array}{c}\text { Unit location } \\
\text { description }\end{array} \\
\end{array}$ & History \\
\hline 1293 & $\begin{array}{l}\text { United Nuclear } \\
\text { Landfill }\end{array}$ & $\begin{array}{l}\text { West of Chestnut } \\
\text { Ridge, just south } \\
\text { of the South } \\
\text { Patrol Road bear } \\
\text { the junction with } \\
\text { West Patrol Road. }\end{array}$ & $\begin{array}{l}\text { From June } 1982 \text { to November 1984, this site received waste from } \\
\text { the decommissioning of a UNC uranium recovery facility in } \\
\text { Wood River Junction, Rhode Island. Drums were generally } \\
\text { stacked } 10 \text { high, following the contour of the excavation and } \\
\text { tapering to the limits of the excavation. The wooden boxes were } \\
\text { placed near the southern perimeter of the pit. The entire water site } \\
\text { covered with PVC sheeting. Over time, this sheeting and many of } \\
\text { the drums and boxes deteriorated, allowing waste material to be } \\
\text { exposed to the environment. Soil samples obtained in } 1986 \text { in the } \\
\text { vicinity of the disposal site indicated that the wastes had not } \\
\text { leached significantly into the subsurface soil. Groundwater } \\
\text { monitoring (1986-90) also failed to indicate leakage of } \\
\text { contaminants into groundwater. However, based on the } \\
\text { deteriorated condition of the waste containers, the estimated } \\
\text { source inventory, and mobility of waste constituents, the UNC } \\
\text { Disposal Site was deemed a potential risk to human health and } \\
\text { the environment. Accordingly, the major goal of the response } \\
\text { action was to prevent or minimize the contamination of shallow } \\
\text { groundwater beneath and downgradient of this site. }\end{array}$ \\
\hline
\end{tabular}

1551 East Chestnut Located south of Ridge Study Area the eastern portion (\#20) of the Y-12 Plant

\section{Industrial}

Landfill IV

\section{Industrial}

landfill VI
TBD

TBD
1400 acres

Class II

Industrial Waste

Landfill.

Class IV

Construction/

Demolition

Landfill. Inactive

- last waste

received 7/8/02.
SWMU HSWA

permit

appendix classification $^{a}$

A-2

9/16/93, post

Annual

ongoing. 
Table B.1 (continued)

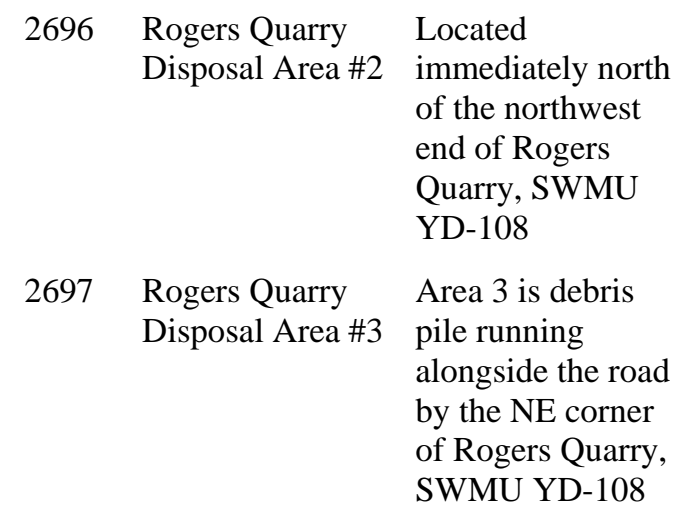

2787 Chestnut Ridge TBD

Soils

Surface debris

removed from

the area in Sept.

2000

Will be

addressed

in the

Chestnut

Ridge

ROD.

SWMU HSWA

permit

appendix

Class II

Industrial Waste

Landfill.

Surface debris

removed from

the area in Sept.

2000 


\section{Table B.1 (continued)}

SWMU HSWA

permit

appendix

\begin{tabular}{|c|c|c|c|}
\hline $\begin{array}{l}\text { Unit ID } \\
\text { number }\end{array}$ & Unit title & $\begin{array}{l}\text { Unit location } \\
\text { description }\end{array}$ & History \\
\hline 2788 & $\begin{array}{l}\text { Chestnut Ridge } \\
\text { Groundwater }\end{array}$ & TBD & \\
\hline
\end{tabular}

3090 Rogers Quarry Along the

Rogers Quarry at

the foundations of

old quarry

operation.

3091 Construction/ South side of

Demolition

Chestnut Ridge at

the end of Clear

Spring Road at

Y-12 Plant.

Note: Information presented in this appendix is derived from RAIMS download as of 12/22/2003. Units have been placed within their appropriate watersheds for the purposes of this Soil Management Plan.

${ }^{a}$ Classifications per Tables A-1 and A-2 to the Resource Conservation and Recovery Act (RCRA) Hazardous and Solid Waste Amendments (HSWA) permit historical $=$ site removed from the HSWA list or evaluated as a potential solid waste management unit, but not selected based on the evaluation.

A-1(a) = site requiring further investigation under the Oak Ridge Reservation Federal Facilities Agreement.

A-2 = site for which no further investigation or action is required (e.g., no further action decision, clean closure, or Comprehensive Environmental Response, Compensation, and Liability Act final action complete). 
04-120(E)/030205 
APPENDIX C

EXCAVATION PERMIT 
04-120(E)/030205 


\section{EXCAVATION PERMIT}

PROJECT/JOB TITLE

DESCRIPTION OF WORK

\begin{tabular}{l|l}
\hline LOCATION PLANT COLUMN & OTHER \\
\hline PERMIT BOUNDARIES/LIMITS & WORK ORDER/CONTRACT NUMBER \\
\hline REQUESTER (NAME AND ORGANIZATION) & PHONE \\
\hline
\end{tabular}

DRAWING/SKETCH NUMBER(S)

ON THE BASIS OF INFORMATION AVAILABLE, UNDERGROUND, EMBEDDED, OR HIDDEN UTILITIES MARKED "YES" IN THE TABLE BELOW ARE KNOWN TO EXIST AT OR ADJACENT TO THE EXCAVATION(S) COVERED BY THIS PERMIT. THIS LISTING MAY NOT BE A COMPLETE DESCRIPTION OF ALL OBSTRUCTIONS. SITE UTILITIES DRAWINGS ARE NOT COMPLETE AND MAY CONTAIN INACCURACIES. THOSE PERFORMING EXCAVATION WORK MUST BE ALERT TO ENCOUNTERING UNCHARTED OR INACCURATELY CHARTED UNDERGROUND OBSTRUCTIONS. STOP WORK IMMEDIATELY AND CONTACT THE PERMIT ISSUER IF OBSTRUCTIONS OTHER THAN THOSE DEFINED ARE ENCOUNTERED. NOTE: ALL NON-DOUBLE INSULATED DRILLING AND CUTTING SHALL BE GROUNDED IN ACCORDANCE WITH ES-1.2-6.

\begin{tabular}{|c|c|c|c|c|c|c|c|c|c|c|c|c|c|c|}
\hline UTILITY & DISC & YES & $\begin{array}{c}\text { UN. } \\
\text { KNOWN }\end{array}$ & INIT & UTILITY & DISC & YES & $\begin{array}{c}\text { UN- } \\
\text { KNOWN }\end{array}$ & INIT & UTILITY & DISC & YES & $\begin{array}{c}\text { UN- } \\
\text { KNOWN }\end{array}$ & INIT \\
\hline 1 SANITARY SEWERS & $\mathrm{cv}$ & & & & 10 CHILLED WATER & FMS & & & & 19. NATURAL GAS & FMS & & & \\
\hline 2. STORM DRAINS & CV & & & & 11 COOLING WATER & FMS & & & & $20 \mathrm{ACID}$ & FMS & & & \\
\hline 3. CATHODIC PROTECTION & EE & & & & 12. RAW WATER & FMS & & & & 21. AIR & FMS & & & \\
\hline 4. ELECTRICAL & $\mathrm{EE}$ & & & & 13 HIPRESS FIREWATER & FMS & & & & 22 OXYGEN & FMS & & & \\
\hline 5. TELEPHONE COMM & EE & & & & 14 STEAM/CONDENSATE & FMS & & & & 23. HYDROGEN & FMS & & & \\
\hline 6. FIRE ALARM & $\mathrm{EE}$ & & & & 15. TOWER WATER & FMS & & & & 24 NITROGEN & FMS & & & \\
\hline 7 GROUND GRID & $\mathrm{EE}$ & & & & 16 PROCESS WASTE & FMS & & & & 25 OTHER (LIST) & & & & \\
\hline 8. SANITARY WATER & FMS & & & & 17 LIQ LOW LEVEL WASTE & FMS & & & & 26 OTHER (LIST) & & & & \\
\hline 9 RECIRCULATING WATER & FMS & & & & 18 OIL & FMS & & & & 27 OTHER (LIST) & & & & \\
\hline
\end{tabular}

CIVIL ENGINEERING

CIVIL ENGINEERING

\begin{tabular}{|l|l|l}
\hline REVIEWER & PHONE & DATE \\
\hline
\end{tabular}

ELECTRICAL ENGINEERING

\begin{tabular}{|l|l|l|}
\hline REVIEWER & PHONE & DATE \\
\hline
\end{tabular}

PIPING ENGINEERING

\begin{tabular}{|l|l|l}
\hline REVIEWER & PHONE & DATE \\
\hline
\end{tabular}

STRUCTURAL ENGINEERING 
PERMIT REVIEWED; IS ADDITIONAL KNOWN INFORMATION TO BE PROVIDED? IF YES, SPECIFY DETAILS

\begin{tabular}{l|l|l|l|l}
\hline UTILITIES SUPERVISOR, MECHANICAL & DATE & UTILITIES SUPERVISOR, ELECTRICAL & DATE \\
$\begin{array}{l}\text { PERMIT REVIEWED } \\
\text { BY RADCON: }\end{array}$ & RADCON REPRESENTATIVE & DATE \\
\hline
\end{tabular}

SPECIAL WORK REQUIREMENTS AND PRECAUTIONS

$\square$ NO $\square$ YES IF YES, LIST. (IF ADDITIONAL SPACE IS NEEDED, USE AN ATTACHMENT)

\begin{tabular}{|c|c|c|c|c|}
\hline $\begin{array}{l}\text { COMPANION WORK } \\
\text { PERMITS REQUIRED }\end{array}$ & NO & YES IF YES, LIST. & SIGNATURE - SUPERVISOR IN CHARGE & DATE \\
\hline $\begin{array}{l}\text { SAFETY SYSTEMS } \\
\text { OR TSR AFFECTED }\end{array}$ & NO & $\begin{array}{l}\text { IF YES, LIST WORK } \\
\text { YES REUIREMENTS. }\end{array}$ & & \\
\hline
\end{tabular}

\section{COMMENTS}

\begin{tabular}{|c|c|c|c|c|}
\hline \multirow{2}{*}{$\begin{array}{l}\text { PERMIT } \\
\text { ISSUED TO: }\end{array}$} & SUBCONTRACTOR & \multirow[t]{2}{*}{ FI\&S SERVICE SUPERVISOR } & \multirow[t]{2}{*}{ SIGNATURE - RECIPIENT } & \multirow[t]{2}{*}{ DATE } \\
\hline & SERVICE CONTRACTOR & & & \\
\hline \multirow[t]{2}{*}{$\begin{array}{l}\text { PERMIT } \\
\text { ISSUED BY: }\end{array}$} & STR & \multirow[t]{2}{*}{$\begin{array}{l}\text { GENERAL SUPERVISOR/FIELD } \\
\text { ENGINEER }\end{array}$} & \multirow[t]{2}{*}{ SIGNATURE - ISSUER } & \multirow[t]{2}{*}{ DATE } \\
\hline & SERVICE COORDIR & & & \\
\hline
\end{tabular}

SURVEYS AND/OR PERSONNEL PROTECTION REQUIRED

For all excavations within the $\mathrm{Y}-12$ emergency response boundary [which includes areas inside and outside the security fence(s)], it is a requirement that the person responsible for the excavating process contact Tennessee One Call at 1-800-351-1111 or other area utility companies, as appropriate, in accordance with the Underground Utility Damage Prevention Act. The call is to be made 72 hours prior to the start of work. In an emergency, Tennessee One Call will respond in approximately 2 hours. The instructions received from Tennessee One Call or other utility companies are to be documented and followed. The caller should write the ticket number and date of the call after the service supervisor's name and organization. While this is not an action performed by E\&T personnel, those E\&T personnel involved in the excavation/penetration process need to be aware of this requirement and its mention on the Excavation/Penetration Permit form(s). For work exceeding 15 calendar days, the utility (Tennessee One Call) must be notified again.

SERVICE SUPERVISOR NAME AND ORGANIZATION (PRINT \& SIGN.)

EXCAVATION PERMIT ISSUE DATE

EXCAVATION PERMIT TERMINATION DATE

WERE UTILITIES, UNEXPECTED OBSTRUCTIONS, AND/OR UNUSUAL CONDITIONS ENCOUNTERED? (IF YES, LIST AND DESCRIBE ON ATTACHED SHEET WITH DRAWING NUMBER REFERENCES.)

\section{EXCAVATION WORK COVERED BY THIS PERMIT COMPLETED AT}

\begin{tabular}{l|l|l|l}
\hline TIME & AM & DATE & \\
\hline PM & & SERVICE SUPERVISOR \\
\hline
\end{tabular}




\section{APPENDIX D}

\section{POTENTIAL SOURCE AREAS FOR RADIOACTIVE SOIL CONTAMINATION}


04-120(E)/030205 


\section{Y-12 Site Radiological Characterization Project Summary 1995 - 1997}

\section{$\underline{B A C K G R O U N D}$}

The Y-12 National Security Complex (Y-12) Site Radiological Characterization Project was conducted to further characterize and evaluate the past potential spread of contamination in non-uranium process areas to ensure all areas were being properly controlled and to ensure that non-radiological workers were not receiving unplanned, inadvertent exposures in excess of 100 millirem/year. The results were compared with the latest posting criteria, as prescribed by the U. S. Department of Energy in 10 Code of Federal Regulations 835 and the Radiological Control Standard. Follow-up measurements were taken, as needed, to ensure compliance with the regulation. As a result, minor posting changes were made. This evaluation and subsequent actions are detailed in the Survey Plan discussed below.

\section{DATA SOURCES}

Potential source areas were identified from a variety of information sources, including the Federal Facilities Agreement (FFA), the Comprehensive Environmental Response, Compensation, and Liability Act Remedial Investigation (RI) for the Upper East Fork Poplar Creek (UEFPC) Area, and operational histories. The FFA identifies 75 potential source areas for the UEFPC characterization area. The UEFPC RI Report identified an additional 27 potential areas of contamination, including tanks and process buildings, that are suspect for contributing to watershed contamination. Of the total 102 areas, 59 were identified or suspected to have radiological constituents and/or an associated radiological risk, and 2 have unknown contaminants. These 61 potential source areas for radiological contamination represented the focus of the Radiological Characterization Project. Additionally, included in the table as a cross-reference, are priority areas designated in the 1985 to 1987 Y-12 Radiological Surface Scoping Survey. During this survey, the priority areas were uniquely identified and gridded. Within each grid, a walkover survey using gamma radiation detection instruments was performed. Areas of elevated readings were flagged for biased soil sampling. A systematic soil sample was taken within each grid, even if no readings above background were found. A standard set of radionuclides was used for each analysis.

\section{$\underline{\text { RESULTS }}$}

The 61 potential source areas for radiological contamination are sorted in the following list as: (1) outside the Y-12 fence; (2) outside PIDAS fence, but inside the Y-12 fence; and (3) inside the PIDAS fence. The report issued for this survey included a range of microrem/hour doses for each priority area. In the priority areas, 30 locations were estimated to have dose rates of $800 \mathrm{microrem} / \mathrm{hour}$ or more, which equates to $100 \mathrm{millirem} / \mathrm{year}$, the Y-12 standard for posting in pedestrian/vehicular traffic areas (not continuous occupancy $)^{*}$. An additional nine areas were listed with $>35,000 \mathrm{pCi} / \mathrm{gm}$, which is estimated to exceed 100 millirem/year.* Configuration, structures, or use of some areas, may have changed in recent years, but residual contamination underground remains probable. Attention is directed to outdoor posting and dose rate measurements, because all buildings were evaluated as part of the 1995 to 1997 Y-12 Site Characterization Project. Additionally, included in the table as a cross-reference, are priority areas designated in the 1985 to 1987 Y-12 Radiological Surface Scoping Survey. 


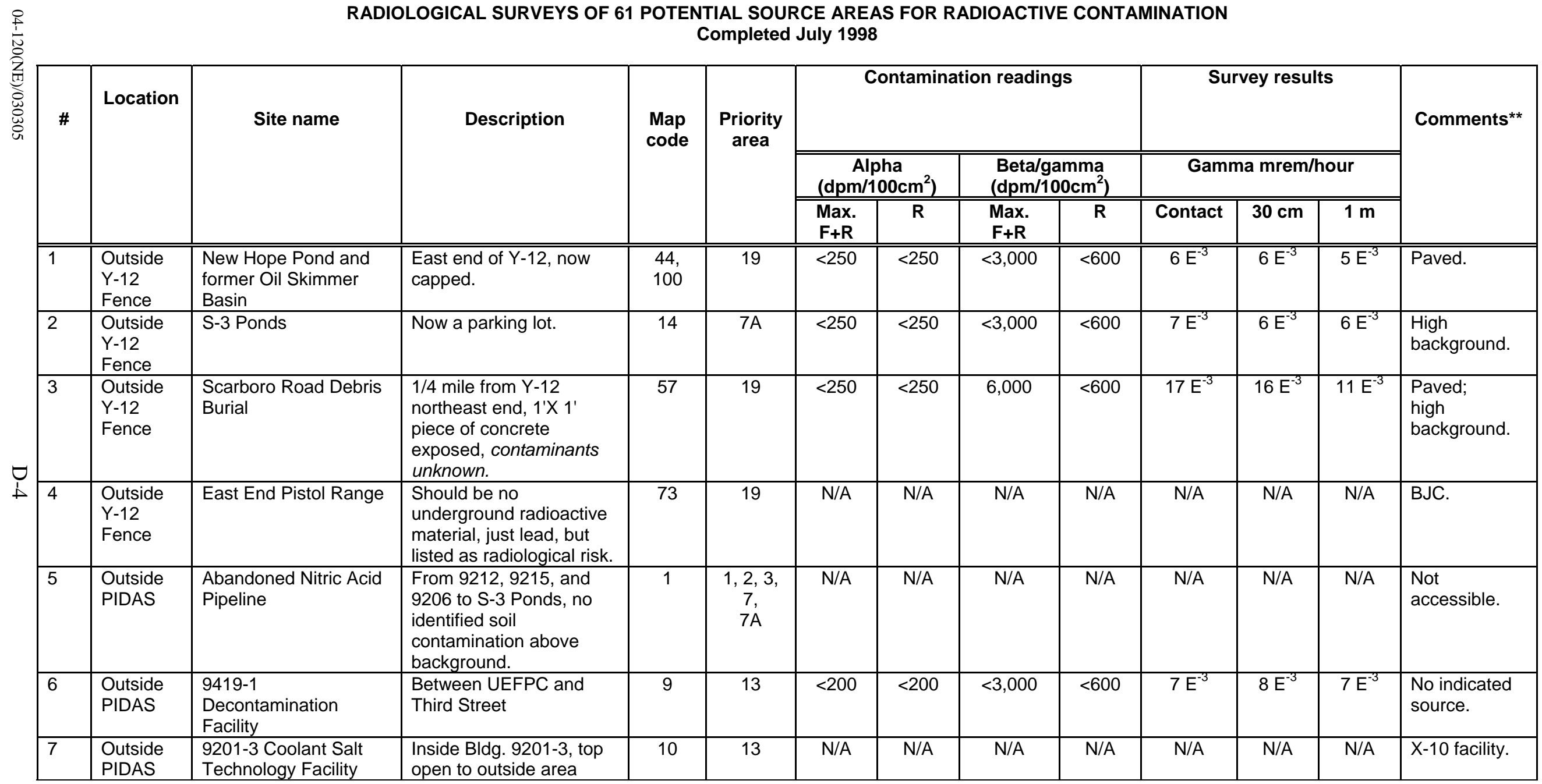




\begin{tabular}{|c|c|c|c|c|c|c|c|c|c|c|c|c|c|}
\hline \multirow{4}{*}{ 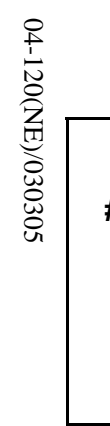 } & \multicolumn{13}{|c|}{$\begin{array}{c}\text { RADIOLOGICAL SURVEYS OF } 61 \text { POTENTIAL SOURCE AREAS FOR RADIOACTIVE CONTAMINATION } \\
\text { Completed July } 1998\end{array}$} \\
\hline & \multirow{3}{*}{ Location } & \multirow{3}{*}{ Site name } & \multirow{3}{*}{ Description } & \multirow{3}{*}{$\begin{array}{l}\text { Map } \\
\text { code }\end{array}$} & \multirow{3}{*}{$\begin{array}{l}\text { Priority } \\
\text { area }\end{array}$} & \multicolumn{4}{|c|}{ Contamination readings } & \multicolumn{3}{|c|}{ Survey results } & \multirow{3}{*}{ Comments* } \\
\hline & & & & & & \multicolumn{2}{|c|}{$\begin{array}{c}\text { Alpha } \\
\left(\mathrm{dpm} / 100 \mathrm{~cm}^{2}\right) \\
\end{array}$} & \multicolumn{2}{|c|}{$\begin{array}{c}\text { Beta/gamma } \\
\left(\mathrm{dpm} / 100 \mathrm{~cm}^{2}\right)\end{array}$} & \multicolumn{3}{|c|}{ "Gamma mrem/hour } & \\
\hline & & & & & & $\begin{array}{l}\text { Max. } \\
F+R \\
\end{array}$ & $\mathbf{R}$ & $\begin{array}{l}\text { Max. } \\
\mathrm{F}+\mathrm{R} \\
\end{array}$ & $\mathbf{R}$ & Contact & $30 \mathrm{~cm}$ & $1 \mathrm{~m}$ & \\
\hline 8 & $\begin{array}{l}\text { Outside } \\
\text { PIDAS }\end{array}$ & 81-10 Area & $\begin{array}{l}\text { Concrete pad and } \\
\text { foundation of original } \\
\text { building (with two sumps) } \\
\text { at corner of } G \text { and Third } \\
\text { Streets. }\end{array}$ & 17 & 4 & $<250$ & $<250$ & 9,000 & $<600$ & $6 \mathrm{E}^{-3}$ & $5 \mathrm{E}^{-3}$ & $6 \mathrm{E}^{-3}$ & $\begin{array}{l}\text { No indicated } \\
\text { source; } \\
\text { sumps not } \\
\text { accessible. }\end{array}$ \\
\hline 9 & $\begin{array}{l}\text { Outside } \\
\text { PIDAS }\end{array}$ & $\begin{array}{l}9202 \text { East Pad Waste } \\
\text { Storage Area }\end{array}$ & $30^{\prime} X 90^{\prime}$ concrete pad. & 20 & 6 & $<250$ & $<250$ & 300,000 & $<600$ & $\mathrm{~N} / \mathrm{A}$ & $\mathrm{N} / \mathrm{A}$ & $\mathrm{N} / \mathrm{A}$ & $\begin{array}{l}\text { Surveyed } \\
4 / 6 / 98 ; \text { no } \\
\text { dose rate } \\
\text { available. }\end{array}$ \\
\hline 10 & $\begin{array}{l}\text { Outside } \\
\text { PIDAS }\end{array}$ & 9409-5 Storage Facility & $\begin{array}{l}\text { South of UEFPC and } \\
9401-3,33^{\prime} \times 241^{\prime} \\
\text { concrete pad and dike. }\end{array}$ & 27 & 13 & $<250$ & $<250$ & $<3,000$ & $<600$ & $7 \mathrm{E}^{-3}$ & $6 \mathrm{E}^{-3}$ & $7 \mathrm{E}^{-3}$ & \\
\hline 11 & $\begin{array}{l}\text { Outside } \\
\text { PIDAS }\end{array}$ & $\begin{array}{l}\text { 9418-3 Uranium Vault, } \\
\text { subsurface }\end{array}$ & $\begin{array}{l}\text { South of UEFPC and } \\
\text { west of 9404-1. }\end{array}$ & 28 & 13 & $<250$ & $<250$ & 60,000 & $<600$ & $20 \mathrm{E}^{-3}$ & $8 \mathrm{E}^{-3}$ & $6 \mathrm{E}^{-3}$ & $\begin{array}{l}\text { Paved; } \\
\text { high } \\
\text { background. }\end{array}$ \\
\hline 12 & $\begin{array}{l}\text { Outside } \\
\text { PIDAS }\end{array}$ & $\begin{array}{l}\text { 9620-2 West Yard } \\
\text { Waste Storage Area }\end{array}$ & Undiked concrete pad. & 29 & 13 & $<250$ & $<250$ & 12,000 & $<600$ & $11 \mathrm{E}^{-3}$ & $7 \mathrm{E}^{-3}$ & $6 \mathrm{E}^{-3}$ & $\begin{array}{l}\text { Paved; } \\
\text { high } \\
\text { background. }\end{array}$ \\
\hline 13 & $\begin{array}{l}\text { Outside } \\
\text { PIDAS }\end{array}$ & $\begin{array}{l}9712 \text { Northeast Yard } \\
\text { Waste Storage Area }\end{array}$ & Now paved. & 30 & 16 & $<250$ & $<250$ & $<3,000$ & $<600$ & $5 \mathrm{E}^{-3}$ & $6 \mathrm{E}^{-3}$ & $6 \mathrm{E}^{-3}$ & $\begin{array}{l}\text { Paved; } \\
\text { no indication. }\end{array}$ \\
\hline 14 & $\begin{array}{l}\text { Outside } \\
\text { PIDAS }\end{array}$ & $\begin{array}{l}9720-13 \text { West Yard } \\
\text { Waste Storage Area }\end{array}$ & Now paved. & 31 & $\overline{1}$ & $<250$ & $<250$ & 60,000 & $<600$ & $7 \mathrm{E}^{-3}$ & $8 \mathrm{E}^{-3}$ & $8 \mathrm{E}^{-3}$ & Paved. \\
\hline 15 & $\begin{array}{l}\text { Outside } \\
\text { PIDAS }\end{array}$ & $\begin{array}{l}\text { 9720-6 North Polytank } \\
\text { Station }\end{array}$ & Asphalt pads. & 33 & 14 & $<250$ & $<250$ & $<3,000$ & $<600$ & $6 \mathrm{E}^{-3}$ & $7 \mathrm{E}^{-3}$ & $6 \mathrm{E}^{-3}$ & $\begin{array}{l}\text { No indicated } \\
\text { source. }\end{array}$ \\
\hline 16 & $\begin{array}{l}\text { Outside } \\
\text { PIDAS }\end{array}$ & $\begin{array}{l}9766 \text { Beryllium- } \\
\text { Contaminated Ducts }\end{array}$ & $\begin{array}{l}\text { Radioactive particulates } \\
\text { exhausted though } \\
\text { ductwork. }\end{array}$ & 35 & 11 & $\mathrm{~N} / \mathrm{A}$ & $\mathrm{N} / \mathrm{A}$ & $\mathrm{N} / \mathrm{A}$ & $\mathrm{N} / \mathrm{A}$ & $\mathrm{N} / \mathrm{A}$ & $\mathrm{N} / \mathrm{A}$ & $\mathrm{N} / \mathrm{A}$ & $\begin{array}{l}\text { Not } \\
\text { accessible. }\end{array}$ \\
\hline
\end{tabular}




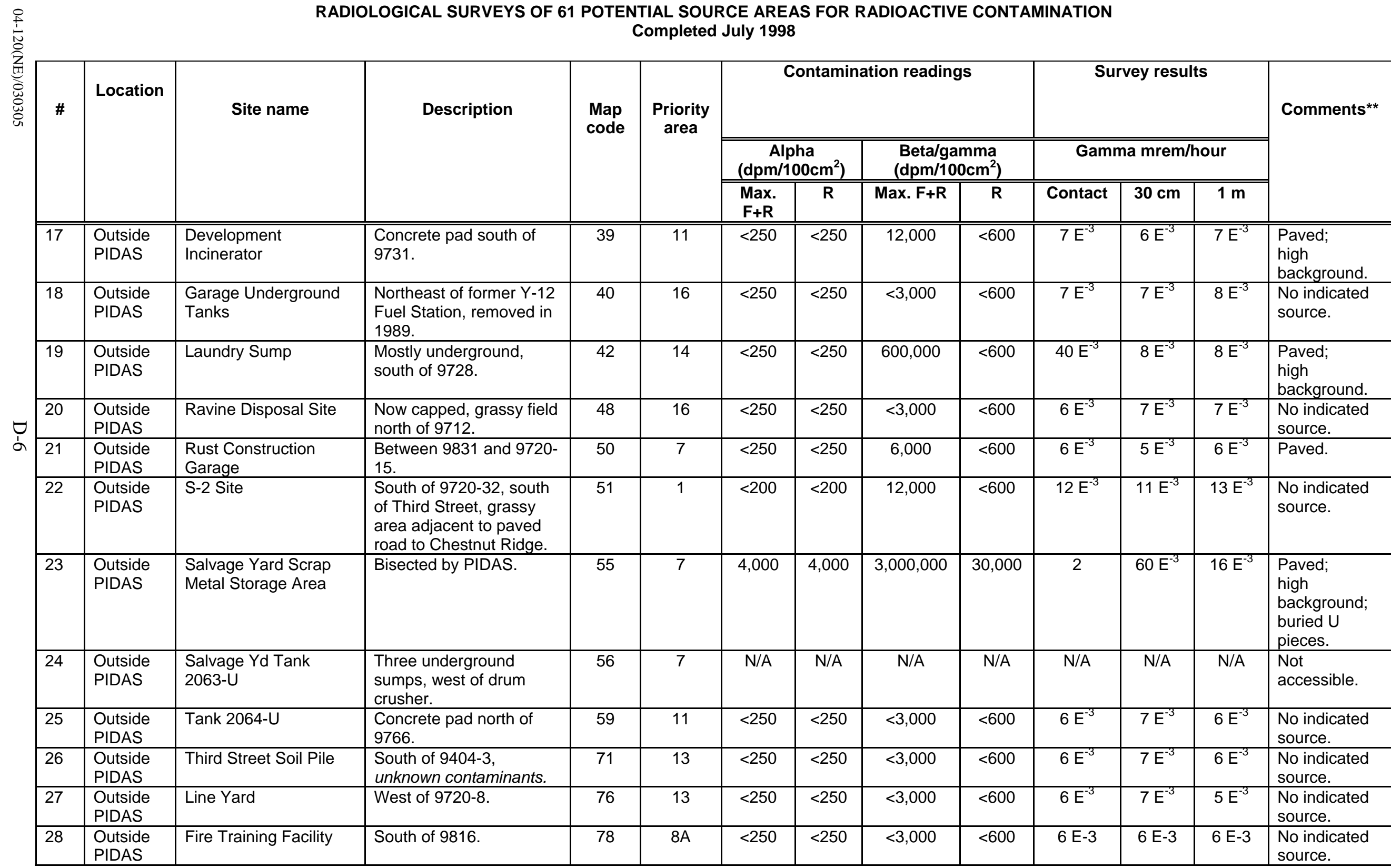


RADIOLOGICAL SURVEYS OF 61 POTENTIAL SOURCE AREAS FOR RADIOACTIVE CONTAMINATION Completed July 1998

\begin{tabular}{|c|c|c|c|c|c|c|c|c|c|c|c|c|c|}
\hline \multirow{3}{*}{$\#$} & \multirow{3}{*}{ Location } & \multirow{3}{*}{ Site name } & \multirow{3}{*}{ Description } & \multirow{3}{*}{$\begin{array}{l}\text { Map } \\
\text { code }\end{array}$} & \multirow{3}{*}{$\begin{array}{l}\text { Priority } \\
\text { area }\end{array}$} & \multicolumn{4}{|c|}{ Contamination readings } & \multicolumn{3}{|c|}{ Survey results } & \multirow{3}{*}{ Comments** } \\
\hline & & & & & & \multicolumn{2}{|c|}{$\begin{array}{c}\text { Alpha } \\
\left(\mathrm{dpm} / 100 \mathrm{~cm}^{2}\right)\end{array}$} & \multicolumn{2}{|c|}{$\begin{array}{l}\text { Beta/gamma } \\
\left(\text { dpm/100 } / \mathrm{cm}^{2}\right)\end{array}$} & \multicolumn{3}{|c|}{ Gamma mrem/hour } & \\
\hline & & & & & & $\begin{array}{l}\text { Max. } \\
F+R\end{array}$ & $\mathbf{R}$ & $\begin{array}{l}\text { Max. } \\
\text { F+R }\end{array}$ & $\mathbf{R}$ & Contact & $30 \mathrm{~cm}$ & $1 \mathrm{~m}$ & \\
\hline 29 & $\begin{array}{l}\text { Outside } \\
\text { PIDAS }\end{array}$ & Tank 0084-U & East of 9712. & 79 & 16 & $<<<250$ & $<250$ & $<<<3,000$ & $<600$ & $7 \mathrm{E}^{-3}$ & $6 \mathrm{E}^{-3}$ & $6 \mathrm{E}^{-3}$ & $\begin{array}{l}\text { High } \\
\text { background. }\end{array}$ \\
\hline 30 & $\begin{array}{l}\text { Outside } \\
\text { PIDAS }\end{array}$ & Tank S-225 & East of 9202. & 83 & 6 & $\mathrm{~N} / \mathrm{A}$ & $\mathrm{N} / \mathrm{A}$ & $\mathrm{N} / \mathrm{A}$ & $\mathrm{N} / \mathrm{A}$ & $\mathrm{N} / \mathrm{A}$ & $\mathrm{N} / \mathrm{A}$ & $\mathrm{N} / \mathrm{A}$ & $\begin{array}{l}\text { Not } \\
\text { accessible. }\end{array}$ \\
\hline 31 & $\begin{array}{l}\text { Outside } \\
\text { PIDAS }\end{array}$ & $\begin{array}{l}\text { Z-Oil Contaminated } \\
\text { Areas }\end{array}$ & $\begin{array}{l}\text { East end Y-12, between } \\
\text { UEFPC and Third Street. }\end{array}$ & 89 & 13 & $<250$ & $<250$ & $<3,000$ & $<600$ & $6 \mathrm{E}^{-3}$ & $5 \mathrm{E}^{-3}$ & $7 \mathrm{E}^{-3}$ & $\begin{array}{l}\text { No indicated } \\
\text { source. }\end{array}$ \\
\hline 32 & $\begin{array}{l}\text { Outside } \\
\text { PIDAS }\end{array}$ & East End Garage & $\begin{array}{l}\text { West of former Y-12 Fuel } \\
\text { Station. }\end{array}$ & 91 & 16 & $<250$ & $<250$ & $<3,000$ & $<600$ & $6 \mathrm{E}^{-3}$ & $7 E^{-3}$ & $7 \mathrm{E}^{-3}$ & $\begin{array}{l}\text { No indicated } \\
\text { source. }\end{array}$ \\
\hline 33 & $\begin{array}{l}\text { Outside } \\
\text { PIDAS }\end{array}$ & GW-605 \& GW-606 & $\begin{array}{l}\text { South of } 9720-8 \text { on } \\
\text { UEFPC. }\end{array}$ & 99 & 14 & $<250$ & $<250$ & $<3,000$ & $<600$ & $11 \mathrm{E}^{-3}$ & $10 \mathrm{E}^{-3}$ & $8 E^{-3}$ & $\begin{array}{l}\text { Paved; } \\
\text { high } \\
\text { background. }\end{array}$ \\
\hline 34 & $\begin{array}{l}\text { Inside } \\
\text { Pidas }\end{array}$ & $\begin{array}{l}9401-2 \text { East Yard } \\
\text { Accumulation Area }\end{array}$ & 20'X 20' paved pad. & 2 & 4 & $<250$ & $<250$ & $<3,000$ & $<600$ & $6 \mathrm{E}^{-3}$ & $7 E^{-3}$ & $7 E^{-3}$ & $\begin{array}{l}\text { No indicated } \\
\text { source. }\end{array}$ \\
\hline 35 & $\begin{array}{l}\text { Inside } \\
\text { PIDAS }\end{array}$ & $\begin{array}{l}\text { 9401-2 Poly Tank } \\
\text { Station }\end{array}$ & $\begin{array}{l}\text { Three tanks on 30'X 156' } \\
\text { Asphalt Pad. }\end{array}$ & 3 & 4 & $<250$ & $<250$ & $<3,000$ & $<600$ & $6 \mathrm{E}^{-3}$ & $6 E^{-3}$ & $6 \mathrm{E}^{-3}$ & $\begin{array}{l}\text { No indicated } \\
\text { source. }\end{array}$ \\
\hline 36 & $\begin{array}{l}\text { Inside } \\
\text { PIDAS }\end{array}$ & Mercury Tank 2101-U & $\begin{array}{l}\text { Underground tank, } \\
\text { southeast of } 9201-4 \text {. }\end{array}$ & 5 & 2 & $<250$ & $<250$ & $<3,000$ & $<600$ & $6 \mathrm{E}^{-3}$ & $7 \mathrm{E}^{-3}$ & $6 \mathrm{E}^{-3}$ & $\begin{array}{l}\text { No indicated } \\
\text { source. }\end{array}$ \\
\hline 37 & $\begin{array}{l}\text { Inside } \\
\text { PIDAS }\end{array}$ & Mercury Tank 2104-U & $\begin{array}{l}\text { Underground tank, } \\
\text { southeast of } 9201-5 \text {. }\end{array}$ & 6 & 2 & $<250$ & $<250$ & 12,000 & $<600$ & $7 E^{-3}$ & $6 \mathrm{E}^{-3}$ & $7 E^{-3}$ & $\begin{array}{l}\text { No indicated } \\
\text { source. }\end{array}$ \\
\hline 38 & $\begin{array}{l}\text { Inside } \\
\text { PIDAS }\end{array}$ & $9201-4$ & Currently D\&D. & 12 & 2 & $\mathrm{~N} / \mathrm{A}$ & $\mathrm{N} / \mathrm{A}$ & $\mathrm{N} / \mathrm{A}$ & $\mathrm{N} / \mathrm{A}$ & $\mathrm{N} / \mathrm{A}$ & $\mathrm{N} / \mathrm{A}$ & $\mathrm{N} / \mathrm{A}$ & BJC. \\
\hline 39 & $\begin{array}{l}\text { Inside } \\
\text { PIDAS }\end{array}$ & Acetonitrile Drum Yard & $\begin{array}{l}\text { Southwest of } 9720-13, \\
\text { asphalt and gravel. }\end{array}$ & 15 & 1 & $<250$ & $<250$ & 30,000 & $<600$ & $7 E^{-3}$ & $6 \mathrm{E}^{-3}$ & $6 \mathrm{E}^{-3}$ & $\begin{array}{l}\text { High } \\
\text { background. }\end{array}$ \\
\hline 40 & $\begin{array}{l}\text { Inside } \\
\text { PIDAS }\end{array}$ & Beta-4 Security Pits & $\begin{array}{l}\text { Mound next to } 9824-1 \text {, } \\
\text { bounded by Patrol Road. }\end{array}$ & 16 & 1 & $<250$ & $<250$ & $<3,000$ & $<600$ & $7 \mathrm{E}^{-3}$ & $7 \mathrm{E}^{-3}$ & $8 E^{-3}$ & \\
\hline 41 & $\begin{array}{l}\text { Inside } \\
\text { PIDAS }\end{array}$ & $\begin{array}{l}9201-5 E \text { Northeast } \\
\text { Yard Waste Storage } \\
\text { Area }\end{array}$ & $\begin{array}{l}30{ }^{\prime} X 60^{\prime} \text { paved area, } \\
\text { northeast corner of } 9201- \\
5 E \text {. }\end{array}$ & 19 & 2 & $<250$ & $<250$ & 30,000 & $<600$ & $6 \mathrm{E}^{-3}$ & $5 E^{-3}$ & $5 \mathrm{E}^{-3}$ & $\begin{array}{l}\text { No indicated } \\
\text { source. }\end{array}$ \\
\hline
\end{tabular}




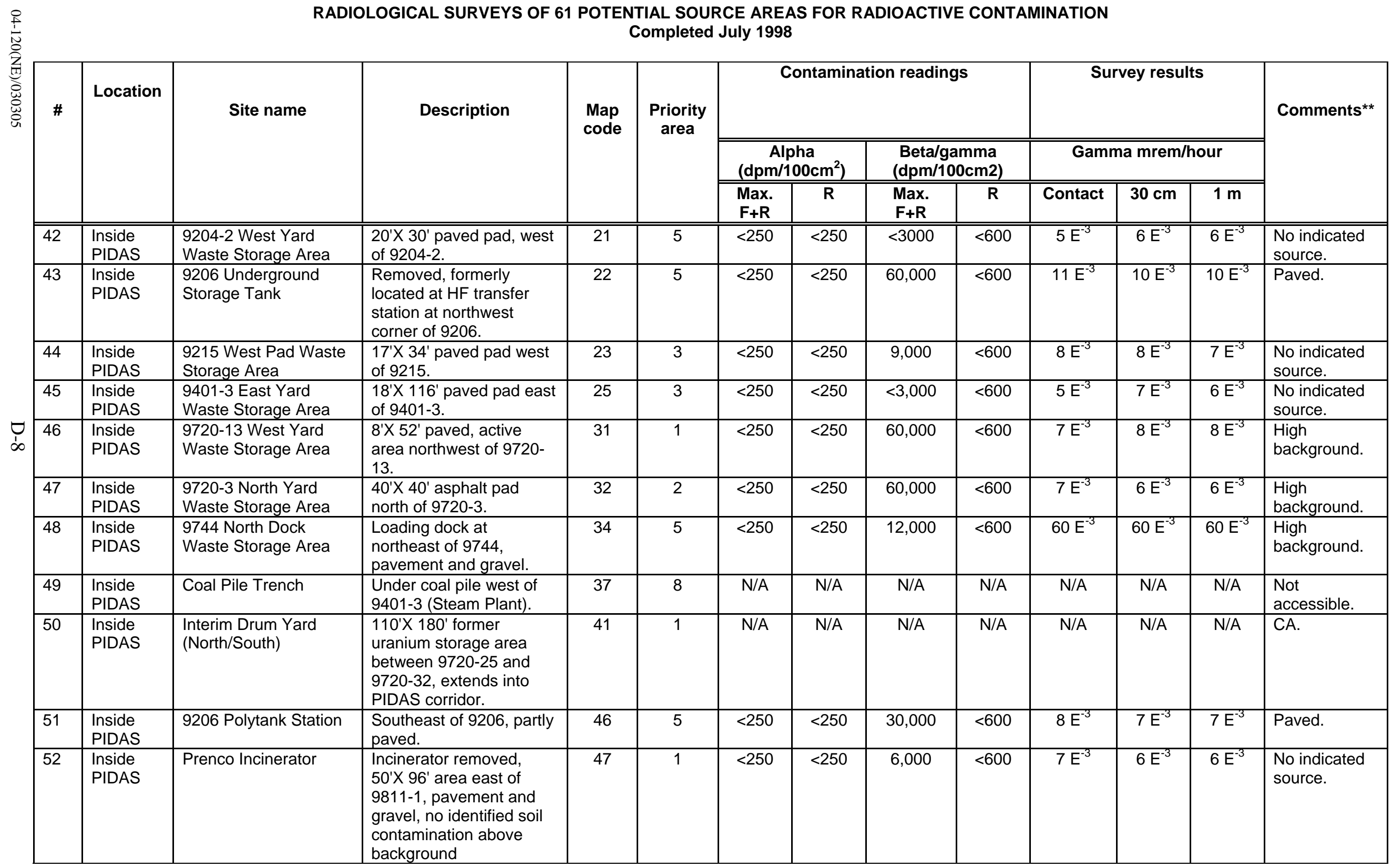




\begin{tabular}{|c|c|c|c|c|c|c|c|c|c|c|c|c|c|}
\hline \multirow{4}{*}{ 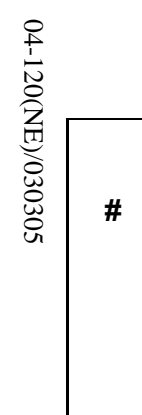 } & \multicolumn{13}{|c|}{$\begin{array}{c}\text { RADIOLOGICAL SURVEYS OF } 61 \text { POTENTIAL SOURCE AREAS FOR RADIOACTIVE CONTAMINATION } \\
\text { Completed July } 1998\end{array}$} \\
\hline & \multirow{3}{*}{ Location } & \multirow{3}{*}{ Site name } & \multirow{3}{*}{ Description } & \multirow{3}{*}{$\begin{array}{l}\text { Map } \\
\text { code }\end{array}$} & \multirow{3}{*}{$\begin{array}{l}\text { Priority } \\
\text { area }\end{array}$} & \multicolumn{4}{|c|}{ Contamination readings } & \multicolumn{3}{|c|}{ Survey results } & \multirow{3}{*}{ Comments** } \\
\hline & & & & & & \multicolumn{2}{|c|}{$\begin{array}{c}\text { Alpha } \\
\left(\mathrm{dpm} / 100 \mathrm{~cm}^{2}\right) \\
\end{array}$} & \multicolumn{2}{|c|}{$\begin{array}{r}\begin{array}{c}\text { Beta/gamma } \\
\left(\mathrm{dpm} / 100 \mathrm{~cm}^{2}\right)\end{array} \\
\end{array}$} & \multicolumn{3}{|c|}{ Gamma mrem/hour } & \\
\hline & & & & & & $\begin{array}{l}\text { Max. } \\
\text { F+R } \\
\end{array}$ & 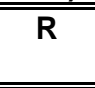 & $\begin{array}{l}\text { Max. } \\
\mathrm{F}+\mathrm{R} \\
\end{array}$ & $\mathbf{R}$ & Contact & $30 \mathrm{~cm}$ & $1 \mathrm{~m}$ & \\
\hline \multirow[t]{3}{*}{53} & $\begin{array}{l}\text { Inside } \\
\text { PIDAS }\end{array}$ & $\begin{array}{l}\text { Former Roofing Waste } \\
\text { Pile }\end{array}$ & $\begin{array}{l}1 / 4 \text { acre waste pile, east } \\
\text { of } 9720-13, \text { removed } \\
1987, \text { no identified soil } \\
\text { contamination above } \\
\text { background. }\end{array}$ & 49 & 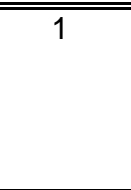 & $<<250$ & $<250$ & $2<3,000$ & $<600$ & $6 \mathrm{E}^{-3}$ & $6 \mathrm{E}^{-3}$ & $7 \mathrm{E}^{-3}$ & $\begin{array}{l}\text { No indicated } \\
\text { source. }\end{array}$ \\
\hline & $\begin{array}{l}\text { Inside } \\
\text { PIDAS }\end{array}$ & Tank 0074-U & $\begin{array}{l}\text { Inside southwest corner } \\
\text { of } 9201-5 \mathrm{~W} \text { basement, } \\
\text { removed, filled and } \\
\text { capped in } 1987 .\end{array}$ & 58 & 2 & $<250$ & $<250$ & $<3,000$ & $<600$ & $6 \mathrm{E}^{-3}$ & $5 \mathrm{E}^{-3}$ & $6 \mathrm{E}^{-3}$ & $\begin{array}{l}\text { No indicated } \\
\text { source. }\end{array}$ \\
\hline & $\begin{array}{l}\text { Inside } \\
\text { PIDAS }\end{array}$ & Tank 2116-U & $\begin{array}{l}\text { Underground tank } \\
\text { southwest of 9204-4, } \\
\text { removed } 1985 .\end{array}$ & 66 & 1 & $\mathrm{~N} / \mathrm{A}$ & $\mathrm{N} / \mathrm{A}$ & N/A & $\mathrm{N} / \mathrm{A}$ & $\mathrm{N} / \mathrm{A}$ & $\mathrm{N} / \mathrm{A}$ & $\mathrm{N} / \mathrm{A}$ & CA. \\
\hline 56 & $\begin{array}{l}\text { Inside } \\
\text { PIDAS }\end{array}$ & $\begin{array}{l}\text { Tank and Transfer } \\
\text { Station 9204-4 }\end{array}$ & $\begin{array}{l}\text { Tank inside and diked } \\
\text { pavement outside east } \\
\text { end of 9204-4. }\end{array}$ & 70 & 1 & $<250$ & $<250$ & $<3,000$ & $<600$ & $5 \mathrm{E}^{-3}$ & $6 \mathrm{E}^{-3}$ & $6 \mathrm{E}^{-3}$ & $\begin{array}{l}\text { No indicated } \\
\text { source. }\end{array}$ \\
\hline 57 & $\begin{array}{l}\text { Inside } \\
\text { PIDAS }\end{array}$ & $\begin{array}{l}\text { Waste Machine } \\
\text { Coolant } \\
\text { Biodegradation Facility }\end{array}$ & $\begin{array}{l}\text { South of 9204-4, } \\
\text { contains two } 40 \text { 'X } 40^{\prime} \text { tile } \\
\text { drain fields. }\end{array}$ & 75 & 1 & $<250$ & $<250$ & $<3,000$ & $<600$ & $7 \mathrm{E}^{-3}$ & $6 \mathrm{E}^{-3}$ & $6 \mathrm{E}^{-3}$ & $\begin{array}{l}\text { High } \\
\text { background; } \\
\text { no indicated } \\
\text { source. } \\
\end{array}$ \\
\hline 58 & $\begin{array}{l}\text { Inside } \\
\text { PIDAS }\end{array}$ & Beta-4 Tanks & $\begin{array}{l}\text { Northeast corner of } \\
9204-4 .\end{array}$ & 81 & 1 & $<250$ & $<250$ & 30,000 & $<600$ & $7 \mathrm{E}^{-3}$ & $6 \mathrm{E}^{-3}$ & $7 \mathrm{E}^{-3}$ & $\begin{array}{l}\text { High } \\
\text { background. }\end{array}$ \\
\hline 59 & $\begin{array}{l}\text { Inside } \\
\text { PIDAS }\end{array}$ & Dock 164 & East side 9808. & 86 & 2 & $<250$ & $<250$ & 6,000 & $<600$ & $5 \mathrm{E}^{-3}$ & $6 \mathrm{E}^{-3}$ & $6 \mathrm{E}^{-3}$ & $\begin{array}{l}\text { High } \\
\text { background. }\end{array}$ \\
\hline 60 & $\begin{array}{l}\text { Inside } \\
\text { PIDAS }\end{array}$ & $\begin{array}{l}\text { 9204-4 Southwest } \\
\text { Yard }\end{array}$ & At tanker station. & 88 & 1 & $<250$ & $<250$ & 30,000 & $<600$ & $6 \mathrm{E}^{-3}$ & $7 \mathrm{E}^{-3}$ & $6 \mathrm{E}^{-3}$ & $\begin{array}{l}\text { High } \\
\text { background. }\end{array}$ \\
\hline 61 & $\begin{array}{l}\text { Inside } \\
\text { PIDAS }\end{array}$ & Tank 2081-U & Between 9212 and 9995. & 93 & 3 & $<250$ & $<250$ & 30,000 & $<600$ & $7 E^{-3}$ & $8 \mathrm{E}^{-3}$ & $7 \mathrm{E}^{-3}$ & $\begin{array}{l}\text { Paved; } \\
\text { high } \\
\text { background. }\end{array}$ \\
\hline
\end{tabular}


* SAIC determined from 1985 to 1987 soil survey data that the average exposure concentration in the Y-12 Protected Area is $1,477 \mathrm{pCi} / \mathrm{gm}$, which was evaluated through ResRad modeling to equal a dose of $63 \mathrm{mrem} / \mathrm{year}$, assuming a continuous occupancy exposure scenario. These outdoor areas have only pedestrian/vehicular traffic, not continuous occupancy; therefore, the estimated dose under this exposure scenario would be less than 63 mrem/year. A much higher exposure concentration would be required under the pedestrian/vehicular traffic scenario to reach the allowable 100-mrem/year dose. The following calculation was used to determine an exposure concentration equivalent to $100-\mathrm{mrem} / \mathrm{year}$ dose for pedestrian/vehicular traffic scenario:

Exposure Concentration

$1477.1 \mathrm{pCi} / \mathrm{gm}$
$100 \mathrm{mrem} / \mathrm{year}$

X

$63 \mathrm{mrem} / \mathrm{year}$
$800 \mathrm{microrem} /$ hour

$50 \mathrm{microrem} / \mathrm{hour}$

This results in a calculated exposure concentration $=37,504 \mathrm{pCi} / \mathrm{gm}$ (rounded to $35,000 \mathrm{pCi} / \mathrm{gm}$ ).

** Comments:

(1) Bldgs. 9204-4, 9201-4, 9201-5, and 9201-2 have soil/water contaminants associated with leaks and spills into sumps in the basements.

(2) The Bldg. 9212 complex, 9731, 9201-1, 9201-2, and 9201-3 are probable upgradient UEFPC sources of radioactive contaminants related to past processing and/or leaks and spills of volatile organic compounds.

(3) Outfalls $21,51,54,57$, and 67 discharge detectable levels of radioactive material to surface water.

(4) Information is from $3 / 24 / 1998$ Revision.

BJC = Bechtel Jacobs Company LLC.

$\mathrm{D} \& \mathrm{D}=$ decontamination and decommissioning.

UEFPC = Upper East Fork Poplar Creek. 


\section{RECORD OF DISTRIBUTION}

BWXT Y-12 L.L.C

E. S. Bishop

D. E. Bohrman

T. R. Brown (2)

G. L. Calvert

T. K. Cothron (2)

G. T. Eagle

J. M. Eaton

S. M. Field

C. C. Hill (2)

R. D. Jackson

R. L. Johnson

S. B. Jones

A. C. Kelley

S. K. Little

W. E. Manrod

L. W. McMahon

V. A. Oldham

R. W. Oliver

M. L. Parkison

L. T. Petrowski

A. L. Rackstraw

R. R. Redmond

S. A. Shults

B. E. Skaggs

O. D. Stevens

L. O. Vaughan

M. C. Wiest

YDCC-RC

Y-12 Records Center

Y-12 Records Services (Electronic copy OSTI)

U. S. DEPARTMENT OF ENERGY OAK RIDGE OPERATIONS

J. A. Johnston

R. W. Martin
NATIONAL NUCLEAR SECURITY

ADMINISTRATION - U.S. DEPARTMENT OF ENERGY

J. P. Donnelly

SCIENCE APPLICATIONS

INTERNATIONAL CORPORATION

W.K. Jago (2) 